Historic, Archive Document

Do not assume content reflects current scientific knowledge, policies, or practices. 

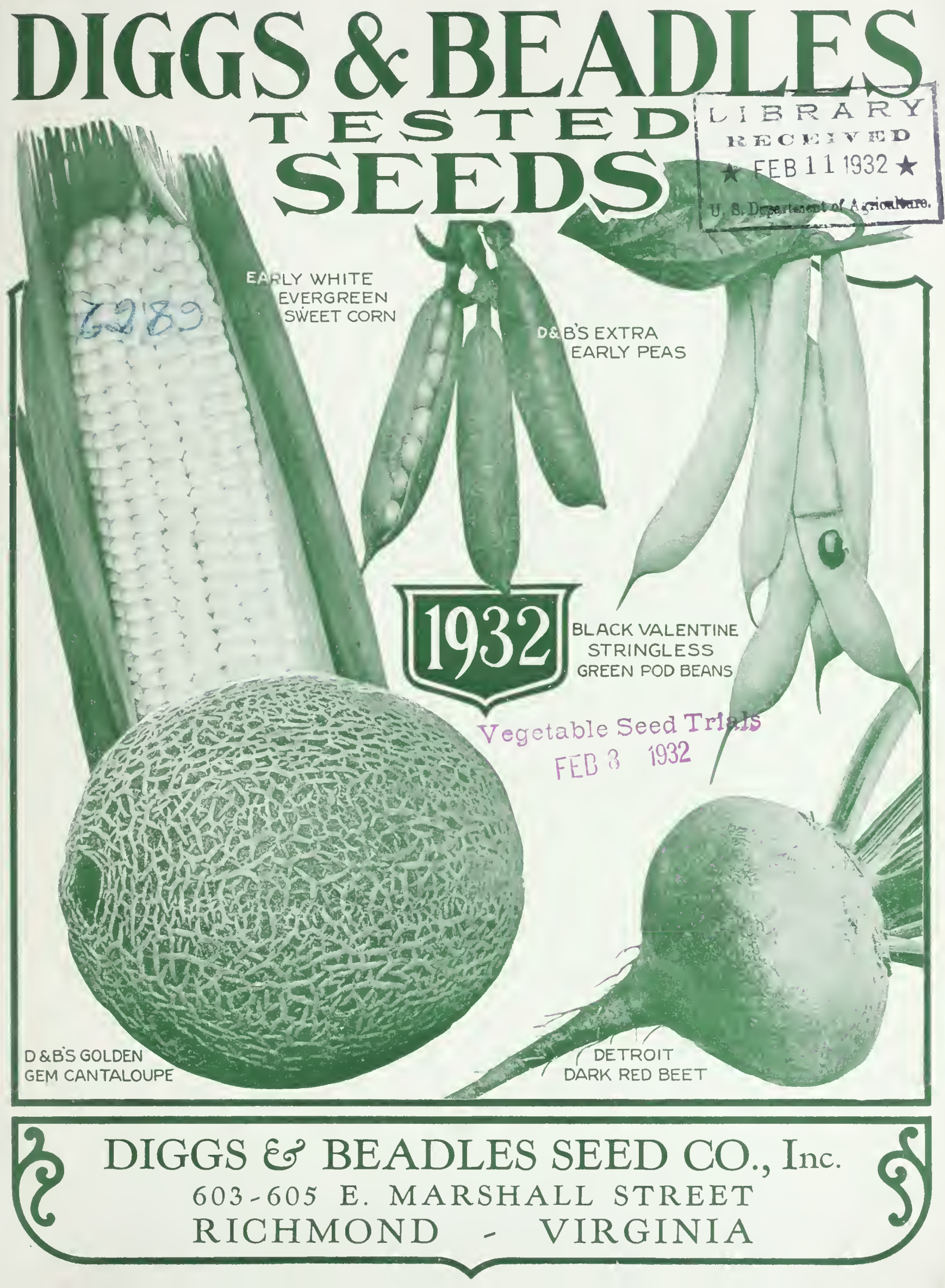


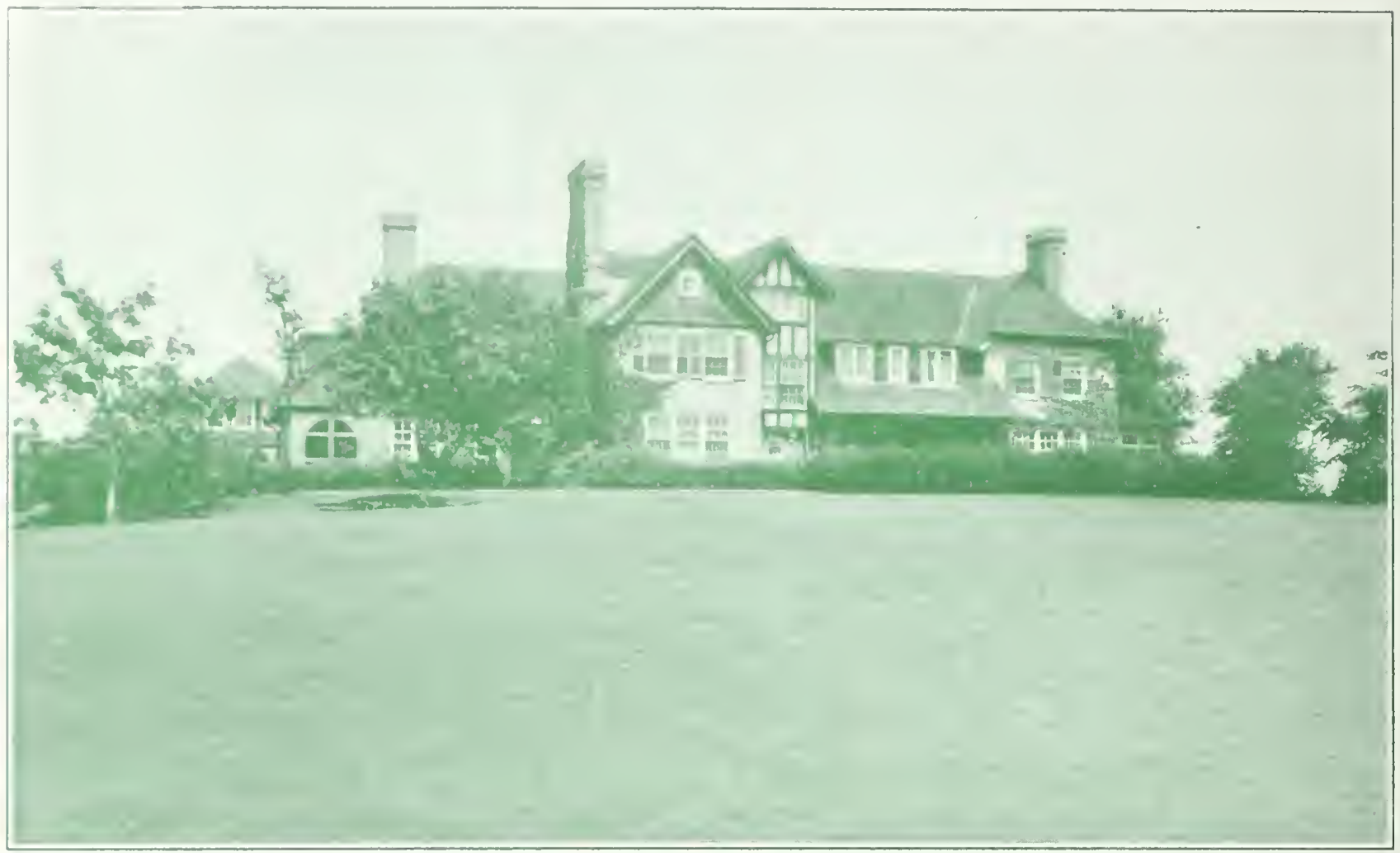

\section{D. \& B.'s VELVET GREEN LAWN GRASS}

1). d B.'s lelvet (ireen Lawn frass is composed entirely of the very highest grade and most suitable Grasses for making a hautiful lawn as respects color, texture and permanency. We have made a careful study of the difficulties met with in liaking a pretty and nermanent lawn, and after many years of experiment we have made this perfectly balanced mixture of Anerican and European Grasses which do best in our climate only the finest grades are used in this mixture, both as to purity and germination.

This is far better than Kentucky Blue Grass, as it proluces a beautiful green velvety sward in 6 to 8 weeks from ime of sowing, and lasts for many years without reseeding. It is better adapted to the different soils, and stands the heat and drought of summer as well as severe cold, better than many of the mixtures so commonly offered.

That we have been successful in securing the most desirable combination is shown in the character of the beautiful lawns surrounding the handsome homes of many of our customers, our city parks, cemeteries, and other public grounds in and around Richmond, as well as many large country estates who use this mixture in large quantities. Every year adds to its popularity and increasing sales.

It should be kept in mind, when comparing prices, that this grass is composed of the choicest, cleanest and heaviest seeds. It produces a beautiful and enduring turf without the aid of cheap, quick growing seeds that are only of temporary value; and we feel safe in saying that a better Lawn Grass camnot be secured at any price. Per lb. 40c; 2 lbs. $75 \mathrm{c} ; 5 \mathrm{lbs}$. $\$ 1.80 ; 10 \mathrm{lbs}$ \$3.35, postpaid. Not prepaid, per $1 \mathrm{lb} .35 \mathrm{c} ; 2 \mathrm{lbs}$. $65 \mathrm{c} ; 5$ lbs. $\$ 1.50 ; 10$ lbs. $\$ 3.00 ; 2.5$ lbs. $\$ 6.75 ; 100$ lbs. $\$ 2.5 .00$.

\section{Shady Place Lawn Grass}

Wi. do not know of any Grass that will flourish and thrive 11) laces that are constantly shady, but this mixture is best adlapted $f(s)$ sowing under trees and other partly shady places

where it is difficult to get other Grasses to grow successfully. 1 lb. 40c: 2 lbs. $75 \mathrm{c}: 5 \mathrm{lbs}$. $\$ 1.80$, postpaid. Not prepaid, 1h. 35c; 2 lbs. 65e; 5 lbs. $\$ 1.50 ; 10$ lbs. $\$ 3.00$.

\section{Preparation and Care of Lawns}

The proper pleparation of the ground in starting a new liwn is essential. This is too often neglected. The ground hould be deeply ploughed, or spaded deep enough to leave a bed of loose earth 4 to 6 inches deep. This should be thoroughly pulverized and raked, removing all sticks, roots and wnes. After getting the ground perfectly smooth, put on an application of D. \& B.'s Lawn Enricher at the rate of 10 munds to 300 square feet, 1,000 to 1,500 pounds' to the acre. I)() NOT USE STABLE MANURE; it is unsightly, and is also, hotherd of weerl seeds and worms, the very thing to ho guarded against in laying a foundation for a pretty lawn. Ho rocommond a thick seedingr, sowing the scerl at the l'ate if 1 pound to the 300 sifuare feet (or aloout 18 feet each way), ar) to 100 prounds to the acre, using 10 pounds of our Lawn linrucher to I pound of Girsss Seed. The land should then l,e gono over with a heavy roller, or the seed raked in thorwahly with a small hand-rake. The best months for seeding al lawn in this section are February, March, April, September, and October. Let the grass get a start of 4 inches before cutting, as too early cutting retards growth; after this cut every ten days. During dry weather it should be watered frequently in the evenings to get the best results.

The best method to renew an old lawn in which the grass is thin and bare in spots, is to go over the lawn loosening the soil tholoughly with a sharp hand-rake. Then sow the seed, after which it is best to roll the ground, covering the seed in this way. It is best also to do this after the grass has been cut and just after a good rain. If this is done in the spring and fall your lawn will be kept thick and flourishing.

A top dressing of D. \& B.'s Lawn Enricher in the early spring and fall is also very beneficial to old lawns already established, and to further fertilize and protect your lawn during the winter cover with tobacco stems at the rate of 50 pounds to 100 squale yards during November or December. A top dressing of agricultural lime in the spring or fall is often very beneficial. 


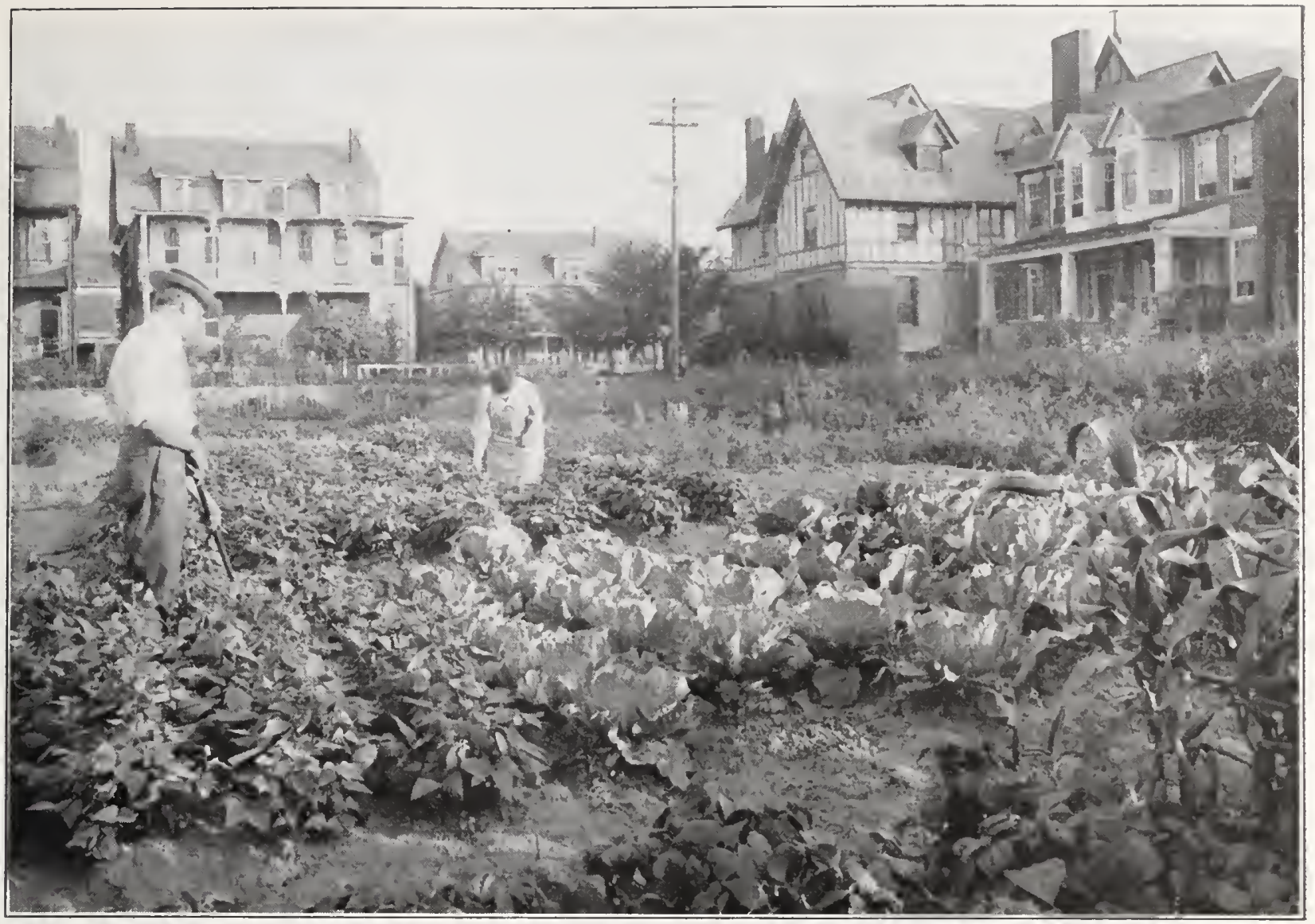

\section{The Home Garden Pays Big Dividends in Healthful Pleasure and Recreation IMPORTANT NOTES AND SUGGESTIONS}

The attention of our customers is respectfully called to the following information, which will avoid misunderstandings and be an aid to purchasers as well as ourselves.

How to Send Money-Remittances may be sent either in the form of a Money Order, Bank Check or Draft, or if currency is sent it should be registered. Postage stamps are satisfactory for small amounts. Customers who have no account with us will kindly remit the amount with their order or name satisfactory business references which must always be given before opening new accounts.

Your Name and Address-Please be careful to give your name and complete address with each order sent us. Every year we receive many orders without name or address given by the sender. If you do not receive your seeds promptly write us. It is likely your order may be among these awaiting identification.

Seeds by Mail-We Guarantee safe arrival of all Seeds and other articles in this catalog at "Postpaid" prices. No other charges for insurance, bags or packing. "Postpaid" means we guarantee safe delivery to your Post office Address. For full information and Parcel Post rates on articles and quantities not quoted postpaid, see following page.

C. O. D. Shipments-Shipping C. O. D. only adds to the cost of the goods as the purchaser pays the expense of collection so we do not advise it. However, if you prefer shipment C. O. D. remit one-half the amount with your order. Under no circumstances will we ship plants or other perishable goods C. O. D.
Fluctuating Prices on Farm Seeds-The prices given in this catalogue on all farm seeds, potatoes, onion sets, and poultry foods are the ruling prices at the time this catalogue goes to our printers in December. The prices on these articles are constantly fluctuating, so the prices as printed in this catalogue may change at any time; but we will enclose with each catalogue, insert price list giving our current prices. It is suggested that orders be sent promptly on receipt of quotations, as prices change frequently, which sometimes causes disappointment to customers who delay placing their orders. However, we are always glad to quote firm prices at any time on request. All quotations are f. o. b. Richmond. If you are a frequent purchaser of seeds and wish to receive our monthly quotations advise us and we will be glad to enter your name on our mailing list for these.

Our Guarantee-D. \& B.'s seeds are thoroughly recleaned, carefully tested and are guaranteed to be as represented in purity, germination, origin and weed content to the full extent of the purchase price. Customers can rest assured that Seeds purchased from us are of high quality and under favorable conditions and with proper cultivation will produce good crops. Yet owing to so many factors over which we have no control such as seeding, soil and weather conditions, the method of cultivating and fertilizing, all of which so vitally affect crop production, we cannot guarantee the crop and are not responsible beyond the purchase price of the seed. 


\section{Parcel Post Zone Map With Rates of Postage}

\section{Parcel Post \\ Information}

Practically all articles listed in this catalog other than poisons and liquids nay be sent by parcel post and as a convenience to our custoners who purchase in quantities usually mailcd we arc quoting postpaid prices on all vegetable seeds and on garden Peas, Beans and Corn up to 10 lbs So when larger quantities of these are ordcred to bc sent by mail add the necessary amount for postage according to the ratc table to the right, which shows at a glance the amount of postage required. We Guarantee safe arrival of all Seeds and other articles in this catalog at "Postpaid" plices. No other charges for insurance, bags or packing. "Postpaid" means we guarantee safe delivery to your Post Office Addrcss.

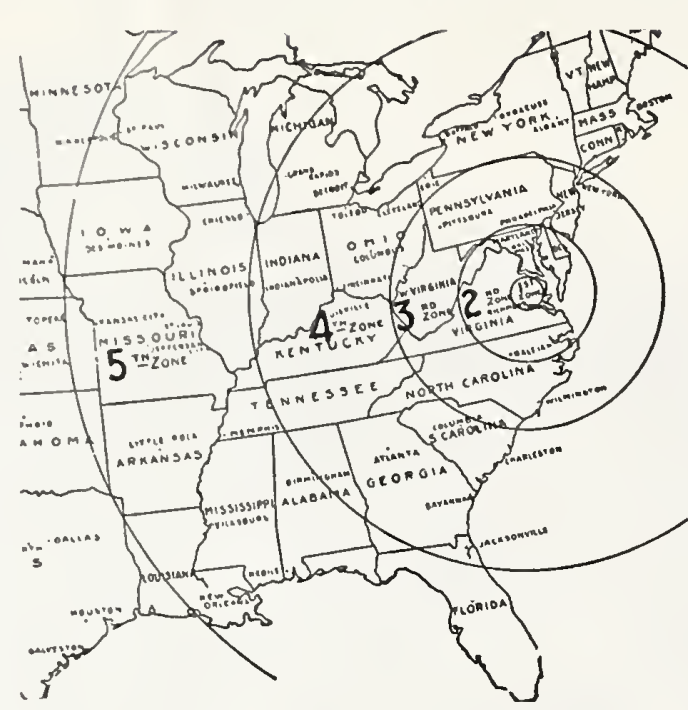

On articles through the Catalogue not quoted postpaid, the mailing weight is given, so that the correct amount of postage can be easily ascertained.

The map above will indicate in what zone you are located, measuring from Richmond, but if you are in doubt as to this, ask your postmaster.

POISONS AND LIQUIDS CANNOT BE SENT BY PARCEL POST

\section{FARM AND GARDEN CALENDAR MONTHLY OPERATIONS FOR THE FARM AND GARDEN WHEN AND WHAT TO SOW.}

The Time of Planting as Given Below Applies for Latitude of Richmond, Therefore Allowances Should Accordingly Be Made for More Northern or Southern Climates.

JANUARY-If your hotbeds have not been prepared attend to them at once and sow Cabbage, Lettuce, Beets, Radish, Cauliflower and Onions. Sow hardy Flower Seeds in hotbeds, for early blooming. Secure
Top-dress grain and grass fieids with manure.

FEBRUARY-Continue top-dressing Grain and Grass fields. Sow in hotbeds or cold frames Cabbage, Lettuce, Beets, Radish, Cauliflower, Onions, Tomato, Egg Plant and Pepper. Latter part of the month sow in open ground Spring Kale. Beets, Spinach, Carrots, Celery, Radish, Parsley, and Eariy Peas. The latter part of the month put out Asparagus and Rhubarb Roots, Onion Sets, hardy Lettuce and Cabbage Plants. Plant Irish Potatoes on high, well-drained soil. Sow Tobacco Seed, Lawn Grass, Winter Oats, Canada Field Peas, Grass and Ciover Seeds.

MARCH-Sow under glass, Tomato, Pepper, Egg Plant, and Flower Seed. Sow outside, Garden Peas, Cauliflower, Cabbage, Lettuce, Beets, Radish, Tarsley, Parsnip. Salsify, Carrots, Celery, Asparagus and Onions. Sow Herb Seed in warm borders. Plant Onion Sets, Irish Potatoes, Asparagus and Rhubarb Roots. Transplant Early Cabbage, Lettuce and Cauliflower plants. Sow Dwarf Essex Rape, Canada Fieid Peas, Winter and Spring Oats, Grass and Clover Seed. Plant Artichokes for hogs. Sow Lawn Grass.

APRIL-Finish sowing Canada Field Peas, Oats, Grass and Clover Seed, plant Irish Potatoes and Artichokes. Bed Sweet Potatoes. Set out Asparagus, Rhubarb and Onions. Sow Cabbage, Lettuce and Tomatoes in open ground for succession. Sow Beets, Carrots, Celery, Radish, Saisify, Parsnip. Parsiey, Spring Kale, Herbs, Mangel Wurzels. Set out Cabbage, Lettuce, Onions, and Beet Plants. Sow hardy Flower Seed outside, piant and cet Plants. Sow hardy Flower seed outthe month if the weather is favorable, plant Cucumbers, Melons, Squash, and Peanuts.

MAY-Finish planting eariy vegetables that were omitted last month. Plant ali varieties of Dwarf and Pole Beans, Black-eye Peas, Cantaloupes, and Watermelons, Cucumber Squash, Okra, Pumpkin and Stock Beets. Sow Tomato and Cabbage Seed for late crop. Set out Tobacco, Cabbage, Lettuce, Caullfower, Tomato, Eg5 Plants, Pepper and Sweet Potato Plants. Sow Flower Seed and piant Flowering Bulbs. Plant Sugar and Fleld Corns, Peanuts and Cotton. Sow Sorghum. Millet, Cow Peas, and ail Fodder Piants.

JUNE-Sow Tomato and Cabbage for late crop. Plant Watermelons, Cantaloupes, Cucumbers, Squash and Pumpkin, Dwarf and Pole Beans, Stock Beets. Sow Millet, Sorghum, Sofa Beans, and all other Fodder Plants.

JULY-For succession, plant Snap Beans, Sugar Corn and Dwarf Lima Beans. Plant Cucumbers for Pickles and Potatoes for late crops. Sow Ruta Bagas and Turnips, also Carrots and Beets for late crop. Set out Cabbage and Celery Plants. Sow Black-eye and Cow Peas, Soja Beans, Buckwheat and Millet.

\begin{tabular}{|c|c|c|c|c|c|}
\hline 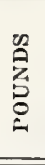 & 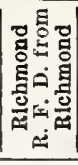 & 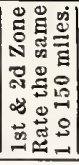 & 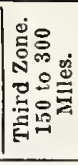 & 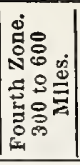 & 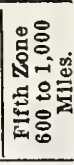 \\
\hline 1 & $\$ .07$ & $\$ .07$ & $\$ .08$ & $\$ .08$ & $\$ .09$ \\
\hline 2 & .08 & .08 & .10 & .12 & .15 \\
\hline 3 & .08 & .09 & .12 & .16 & .21 \\
\hline 4 & .09 & .10 & .14 & .20 & .27 \\
\hline 5 & .09 & .11 & .16 & .24 & .33 \\
\hline 6 & .10 & .12 & .18 & .28 & .39 \\
\hline 7 & .10 & .13 & .20 & .32 & .45 \\
\hline 8 & .11 & .14 & .22 & .36 & .51 \\
\hline 9 & .11 & .15 & .24 & .40 & .57 \\
\hline 10 & . 12 & .16 & .26 & .44 & .63 \\
\hline 11 & .12 & .17 & .28 & .48 & .69 \\
\hline 12 & .13 & .18 & .30 & .52 & .75 \\
\hline 13 & .13 & .19 & .32 & .56 & .81 \\
\hline 14 & .14 & .20 & .34 & .60 & .87 \\
\hline 15 & .14 & .21 & .36 & .64 & .93 \\
\hline 16 & .15 & .22 & .38 & .68 & .99 \\
\hline 17 & .15 & .23 & .40 & .72 & 1.05 \\
\hline 18 & .16 & .24 & .42 & .76 & 1.11 \\
\hline 19 & .16 & .25 & .44 & .80 & 1.17 \\
\hline 20 & .17 & .26 & .46 & .84 & 1.23 \\
\hline 21 & .17 & .27 & .48 & .88 & 1.29 \\
\hline 22 & .18 & .28 & .50 & .92 & 1.35 \\
\hline 23 & .18 & .29 & .52 & .96 & 1.41 \\
\hline 24 & .19 & .30 & .54 & 1.00 & 1.47 \\
\hline 25 & .19 & .31 & .56 & 1.04 & 1.53 \\
\hline 26 & .20 & .32 & .58 & 1.08 & 1.59 \\
\hline 27 & .20 & .33 & .60 & 1.12 & 1.65 \\
\hline 28 & .21 & .34 & .62 & 1.16 & 1.71 \\
\hline 29 & .21 & .35 & .64 & 1.20 & 1.77 \\
\hline 30 & .22 & .36 & .66 & 1.24 & 1.83 \\
\hline 31 & .22 & .37 & .68 & 1.28 & 1.89 \\
\hline 32 & .23 & .38 & .70 & 1.32 & 1.95 \\
\hline 33 & .23 & .39 & .72 & 1.36 & 2.01 \\
\hline 34 & .24 & 40 & .74 & 1.40 & 2.07 \\
\hline 35 & .24 & .41 & .76 & 1.44 & 2.13 \\
\hline 36 & .25 & .42 & .78 & 1.48 & 2.19 \\
\hline 37 & .25 & .43 & .80 & 1.52 & 2.25 \\
\hline 38 & .26 & .44 & .82 & 1.56 & 2.31 \\
\hline 39 & .26 & .45 & .84 & 1.60 & 2.37 \\
\hline 40 & .27 & .46 & .86 & 1.64 & 2.43 \\
\hline 41 & .27 & .47 & .88 & 1.68 & 2.49 \\
\hline 42 & .28 & .48 & .90 & 1.72 & 2.55 \\
\hline 43 & .28 & .49 & .92 & 1.76 & 2.61 \\
\hline 44 & .29 & .50 & .94 & 1.80 & 2.67 \\
\hline 45 & .29 & .51 & .96 & 1.84 & 2.73 \\
\hline 46 & .30 & .52 & .98 & 1.88 & 2.79 \\
\hline 47 & .30 & .53 & 1.00 & 1.92 & 2.85 \\
\hline 48 & .31 & .54 & 1.02 & 1.96 & 2.91 \\
\hline 49 & .31 & .55 & 1.04 & 2.00 & 2.97 \\
\hline 50 & .32 & .56 & 1.06 & 2.04 & 3.03 \\
\hline 51 & .32 & .57 & 1.08 & \multirow{4}{*}{\multicolumn{2}{|c|}{ WEIGHT }} \\
\hline 52 & .33 & .58 & 1.10 & & \\
\hline 53 & .33 & .59 & 1.12 & & \\
\hline 54 & .34 & .60 & 1.14 & & \\
\hline $\begin{array}{l}55 \\
56\end{array}$ & $\begin{array}{l}.34 \\
.35\end{array}$ & .61 & $\begin{array}{l}1.10 \\
1.18\end{array}$ & \multirow{2}{*}{\multicolumn{2}{|c|}{ LIMIT }} \\
\hline 57 & .35 & .63 & 1.20 & & \\
\hline 58 & .36 & .64 & 1.22 & \multirow{2}{*}{\multicolumn{2}{|c|}{ All }} \\
\hline 59 & .36 & .65 & 1.24 & A & \\
\hline 60 & .37 & .66 & 1.26 & \multicolumn{2}{|c|}{ Zones } \\
\hline 61 & .37 & .67 & 1.28 & \multirow{2}{*}{\multicolumn{2}{|c|}{$70 \mathrm{lbs}}}$. \\
\hline $\begin{array}{l}62 \\
63\end{array}$ & $\begin{array}{r}.38 \\
38\end{array}$ & .68 & $\begin{array}{l}1.30 \\
1.32\end{array}$ & & \\
\hline $\begin{array}{l}83 \\
64\end{array}$ & $\begin{array}{r}.38 \\
.39\end{array}$ & $\begin{array}{l}.89 \\
.70\end{array}$ & $\begin{array}{l}1.32 \\
1.34\end{array}$ & & \\
\hline 65 & .39 & .71 & 1.36 & & \\
\hline 70 & .42 & .76 & 1.46 & & \\
\hline
\end{tabular}

AUGUST-This is the best month for sowing Turnip Ruta Bagas and Winter Radish. Sow Spinach, Kale, Lettuce Endive, and Corn Salad. Sow Snap Beans, Peas, Carrots, and Beets for late crop. Sow Crimson Clover, Vetch, Rape, Winter Oats, Rye and Barley for winter grazing. Set out Celery, Lettuce and Cabbage Plants, aiso put out Onion Sets.

SEPTEMBER-Sow Lettuce, Eariy Cabbage and Cauliflower for transplanting. Transplant Lettuce, Cabbage and Celery. Set out Onions, sow Turnips, Kale, Spinach, Winter Radish. Corn Salad and Endive. Sow Lawn Grass and all varieties of Grasses and Clovers. Sow Winter Oats, Rye, Barley, Rape, and Vetch.

OCTOBER-Finish sowing Cabbage, Lettuce, Turnips for Salad, Kale and Spinach. Sow Lawn Grass Seed. Plant Hyacinths, Tulips, and Flowering Bulbs for spring blooming. Finish sowing all varieties of frass and Clover Seed. Sow Dwarf Essex Rape, Vetch, Oats, Wheat, Rye, Winter Peas and Barley.

NOVEMBER-Set out Cabbage, Lettuce, Strawberry Plants and Asparagus Roots. Plant all kinds of Flowerine Bulbs for spring blooming. This is the best month for setting out Fruit and Shade trees. Finish sowing all varieties of Grain and Grass as early in the month as possible. Sow Austrian Winter Peas or Canada Field Peas with Grain.

DECEMBER-Early in the month sow Austrian Winter Peas, Canada Field Peas and Rye, Cabbage, Radish, Lettuce and Beets can be sown in hot beds. 
SEED GRAINS Sacks Included

5 Bus.@Per Bu. $\$ .60 \$ .63$

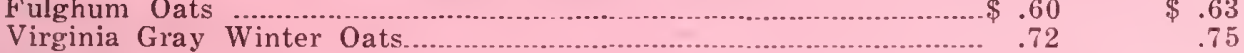

Burt Oats .......................................................................................... $.59 \quad .60$

Bearded Winter Barley

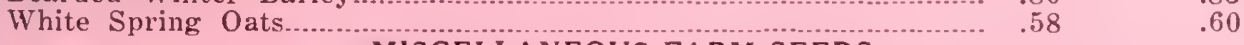

MISCELLANEOUS FARM SEEDS
100 Lbs. 10 Lbs.@ Lb.

Hairy Vetch

Dwarf Essex Rape...................................................... 5.00 $\quad .07 \quad .10$

Austrian Winter ..................................................... $6.00 \quad .08 \quad .08$

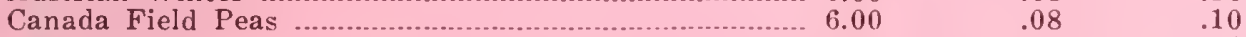

Sudan Grass ............................................................. $4.50 \quad .05 \quad .06$

NO CHARGE FOR SACKS

No extra charge is made for sacks except the $2 \frac{1 / 2}{2}$ bushel Cotton Sacks to hold

Alfalfa, Clovers, Timothy, Herds Grass and Millet Seed. These are charged extra at cost, $25 \mathrm{c}$ each.

\section{Sacks holding 150 lbs., extra@25c each. \\ CLOVERS}

\section{Bushel}

$\$ 4.80$

Crimson Clover

5.10

Red Clover, Central U. S. grown,

purity $99 \%$ Mammoth, Central U. S.

11.10

$\begin{array}{lr}\text { Alsyke, U. S. grown, purity } 98 \% \ldots . & 10.20 \\ \text { Alfalfa, Kansas grown, purity } 99 \% & 9.90\end{array}$

Alfalfa, Kansas grown, purity $99 \% \ldots$ $99 \%$

White Dutch, Fancy.

Korean Lespedeza.

\section{GRASSES}

Sacks holding 100 lbs. extra @25c each fo

*Fancy Cleaned Herds, purity $90 \%$

*Timothy, Purity $99.60 \%$ Per bushel, $\$ 2.25$.

Orchard Grass

Kentucky Blue, Fancy

Domestic Rye

Red Fescue

Meadow Fescue

Colonial Bent

* Bermuda Grass

ONION SETS

White Silver Skin

SELECTED SEED POTATOES

Japanese Potato

Main Grown Irish Cobblers

Virginia Grown Irish Cobblers

Virginia Grown Spaulding's Rose

Virginia Grown Snow.

Virginia Grown Green Mountain.

CORRECTIONS IN CATALOGUE PRICES on page 5 ,

Stringless Black Valentine, by mail postpaid.

Siringless Black Valentine, by mail not prepaid.

Sulphate of Ammonia and Nitrate of Soda on botiom of page 60 in catalogue, per ton.... $\$ 47.00$

\section{BUSH SNAP BEANS}

lb. 2 lbs. 5 lbs. 10 lbs. 100 lbs.

$$
\begin{array}{lllllllll}
\$ \ldots & . .10 & \$ .20 & \$ .35 & \$ & .55 & \$ 1.20 & \$ 2.10
\end{array}
$$

100 Lbs.
$\$ 8.00$
8.50
10 Lbs.@
$\$ .09$
.10

8.50

18.50

.19

18.50

17.00

16.50

.19

.18

.17

8.00

.10

41.50

18.00

.43

.21

Lb.

$\$ \quad .15$

.15

$.121 / 2$

.15

Peck

Lb.

.12

.21

.21

.20

.19

.12

.45

.23

arieties marked (*).

$\$ 11.00$

$\begin{array}{rr}10 & \text { Lbs. } \\ \$ & .13\end{array}$

.08

.12

.18

.08

.35

.13

.78

.19

10 Lbs.

$\$ \quad .95$

.80

.85

.90

Bus.

$\$ 1.25$

1.25

1.25

1.25

1.25

@

Lb.

$\$ \quad .15$

.10

.14

.20

.10

.38

.15

.80

.21

Bus.

32 Lbs.

$\$ 2.15$

1.90

2.75

2.00

Sack

150-lb.

$\$ 2.75$

2.75

2.75

2.75

2.75 


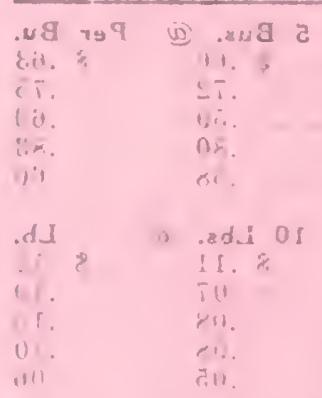

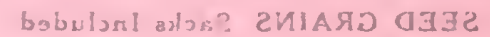

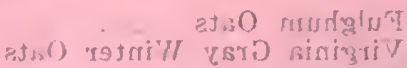

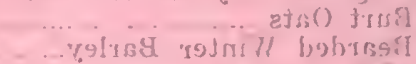

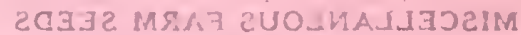

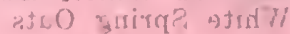
edd 001

ilit:

טก.

hloj, V V.s $5 \mathrm{H}$

010.0

948:I $x 925.7$ iтs 1 (1

(II). 1 - intrith msitjent.

$11 i, 1$

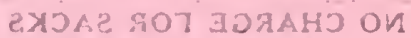

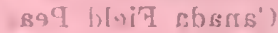
अनकी

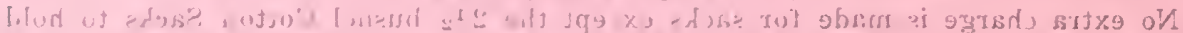

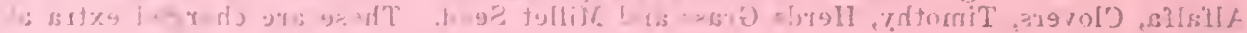

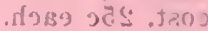

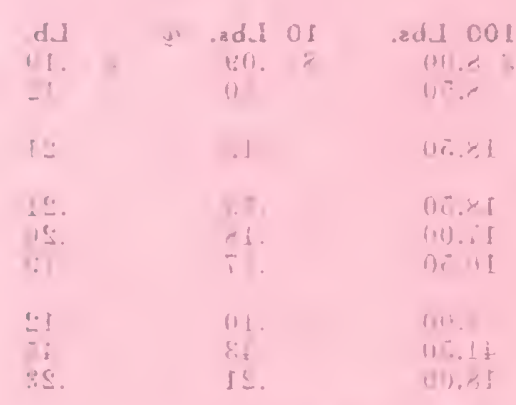

\section{2ก7. 013}

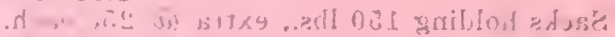

9riand

(14.1 द्ध

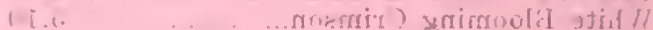

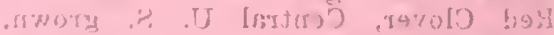

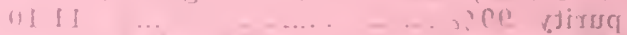

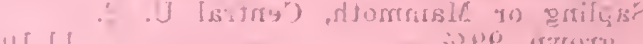

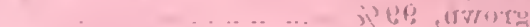

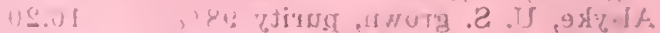

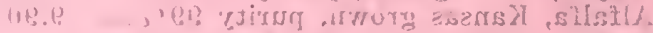

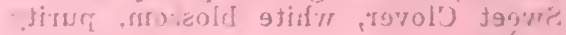
$(1+.1$

\section{2झ२२АЯ}

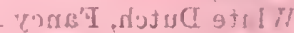

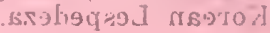

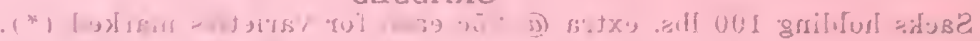

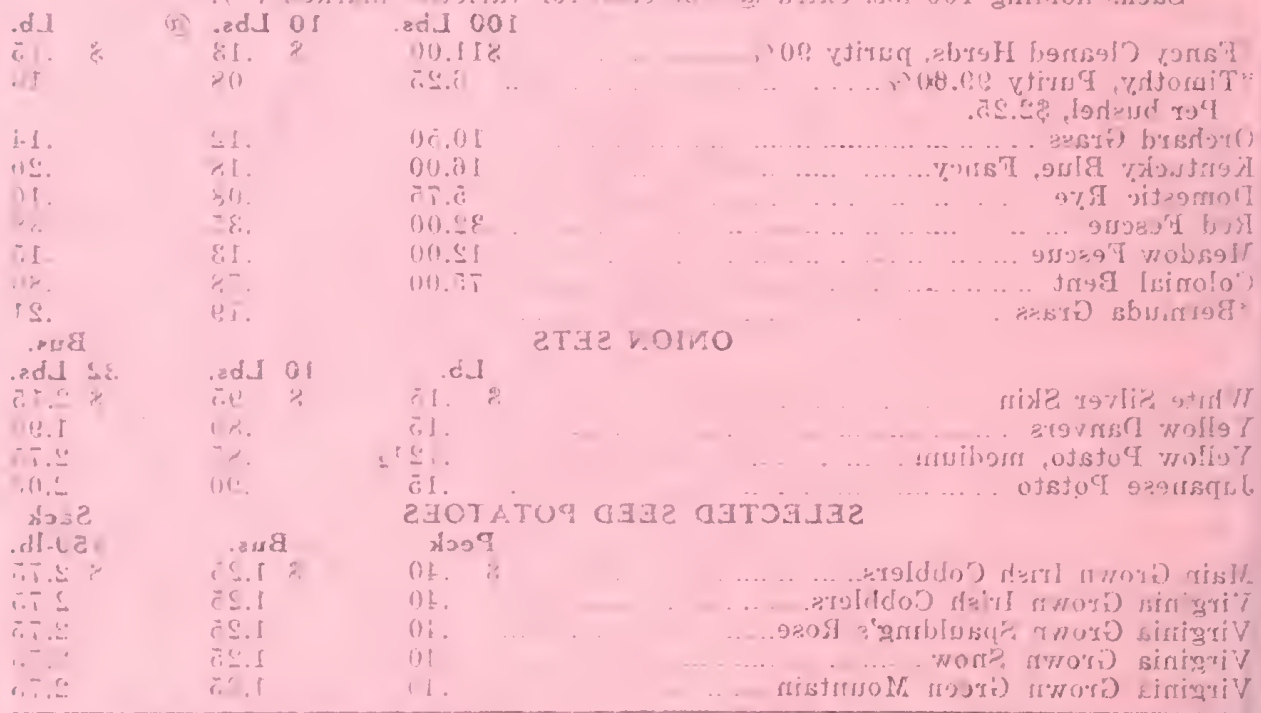

¿MA.ZR 9AM2 HZUU

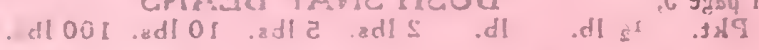

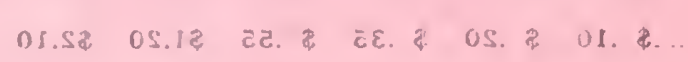

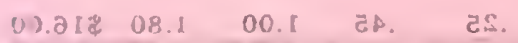

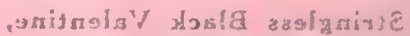
bisqieóng lism प⿺

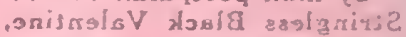
bisq9rq fors lism rd

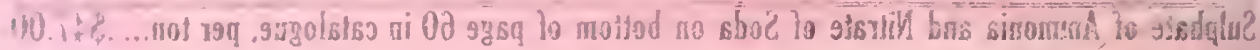




\section{DIGGS \& BEADLES SEED CO., Inc. SEED MERCHANTS RICHMOND, VA.}

For helpful information about ordering see opening pages of catalog

Please forward the following, as per terms of your AMOUNT ENCLOSED catalogue :

Date

Send to

(Name)

Post

Office

(Write plainly-Ladies will please put the prefix Miss or Mrs.)

(Loose Money is not safe)

\section{Money}

Order

Order No.

Check

or Draft

(Write plainly)

, State or Draft

\section{County}

Shipping Depot or Express Office if not same as Post Office

\section{On What Railroad is Your Shipping Point?}

OUR GUARANTEE-D, \& B's seeds are thoroughly recleaned, carefully tested and are cuaranteed to be as represented in purity, germination, origin and weed content to the full extent of the purchase price. Owing to so many factors over which we have no control such as seeding, soil conditions, the method of cultivating and fertilizing all of which so vitally affect crop production, we cannot guarantee the crop and are not responsible beyond the purchase price of the seed.

SEND BY $\begin{aligned} & \text { Show how you want goods sent by } \\ & \text { marking } x \text { in the proper square. }\end{aligned}$

\begin{tabular}{c|c} 
Shipper's \\
Check
\end{tabular} QUANTITY marking $x$ in the proper square.
Freight

ARTICLES WANTED

Be sure and add postage to articles ordered sent by mail if not quoted postpaid
Express
Date

Shipped

Shipped by

Put up by

Stamps

sticking
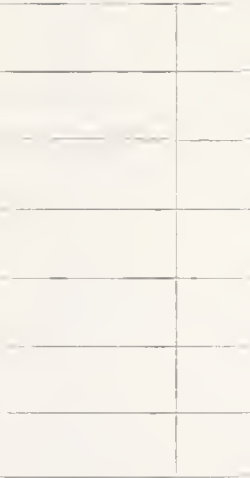
THE GARDENER'S GUIDE AND SOWING TABLE

Thls Table has been carefully prepared and answers hundreds of questions Gardeners and Farmers want to know. Time of pianting is for tatltude of Rlchmond, therefore allowances should accordingiy be made for more Northern or Southern cilmates. For fuller lnstructions see cuitural dlrections under the heading of each klnd of vegetable.

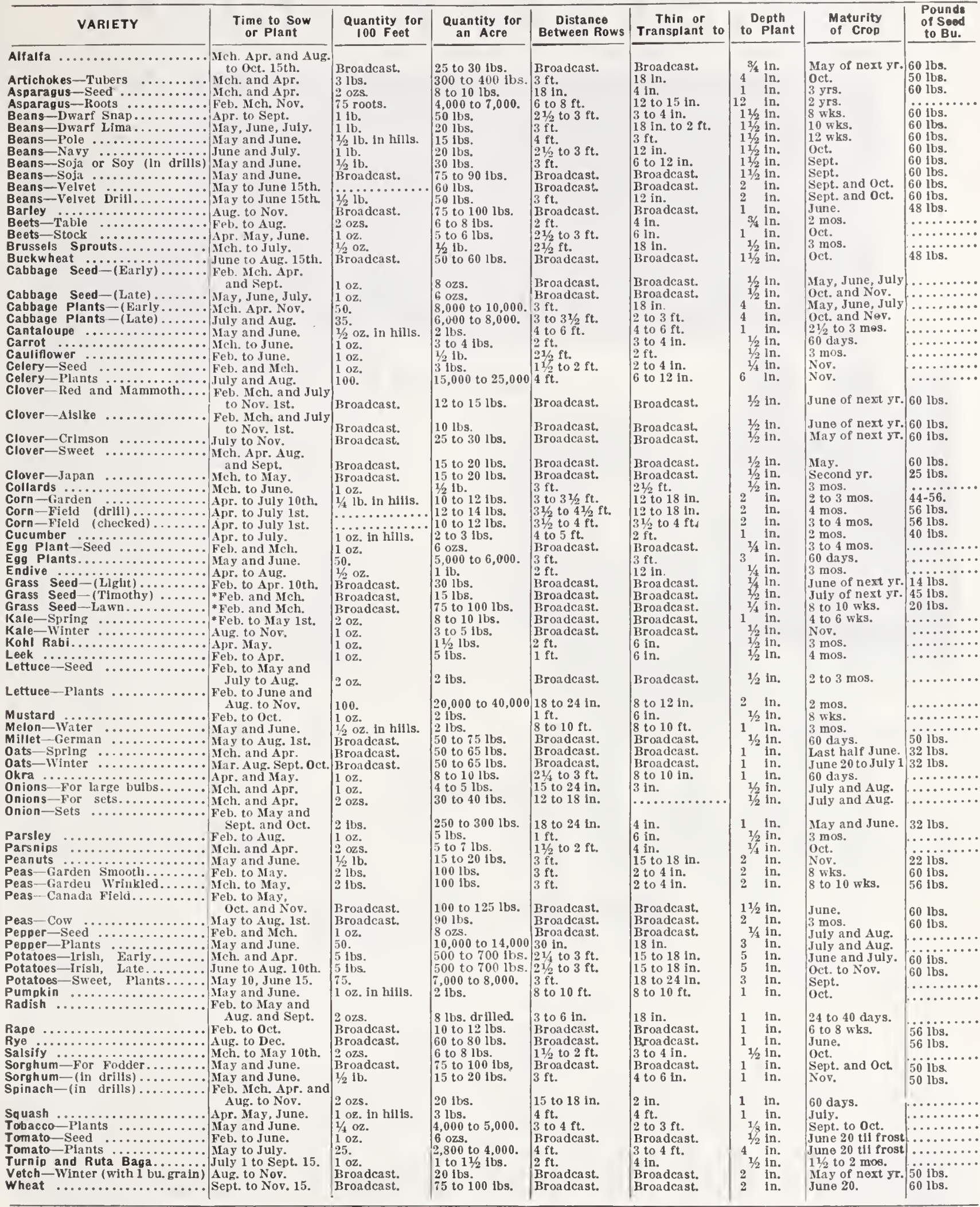




\section{VEGETABLE SEEDS}
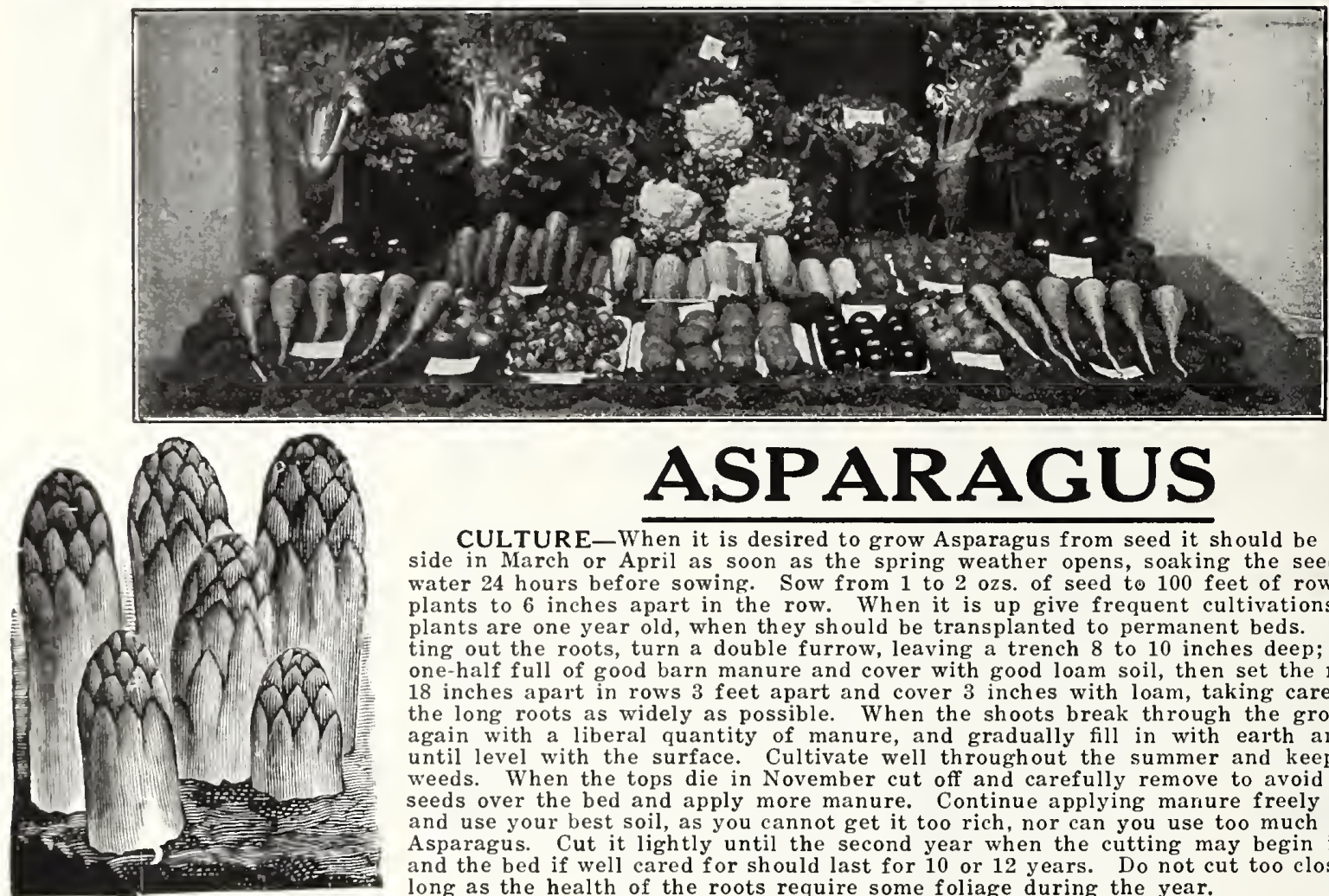

\section{ASPARAGUS}

CULTURE-When it is desired to grow Asparagus from seed it should be sowed outside in March or April as soon as the spring weather opens, soaking the seed in warm water 24 hours before sowing. Sow from 1 to $2 \mathrm{ozs}$. of seed to 100 feet of row, and thin plants to 6 inches apart in the row. When it is up give frequent cultivations until the plants are one year old, when they should be transplanted to permanent beds. When putting out the roots, turn a double furrow, leaving a trench 8 to 10 inches deep; fill trench one-half full of good barn manure and cover with good loam soil, then set the roots 16 to 18 inches apart in rows 3 feet apart and cover 3 inches with loam, taking care to spread the long roots as widely as possible. When the shoots break through the ground, cover again with a liberal quantity of manure, and gradually fill in with earth and manure until level with the surface. Cultivate well throughout the summer and keep down all weeds. When the tops die in November cut off and carefully remove to avoid scattering seeds over the bed and apply more manure. Continue applying manure freely each year, and use your best soil, as you cannot get it too rich, nor can you use too much manure on Asparagus. Cut it lightly until the second year when the cutting may begin in earnest, and the bed if well cared for should last for 10 or 12 years. Do not cut too closely or too long as the health of the roots require some foliage during the year.

Washington A rust resistant and vigorous growing Asparagus introduced by the U. S. Department of Agriculture. It produces large, straight stalks of excellent quality with firm and delicious tips. It is said by experienced growers of Asparagus to be so far superior to the old standard sorts that we have discontinued carrying all other varieties. Oz. 15c; 1, lb. 35c; lb. \$1.10, postpaid.

Asparagus Roots In order to have Asparagus quickly, it is more satisfactory to grow it from the roots.

WASHINGTON-Two-year-old roots, 50 for $\$ 1.10 ; \$ 2.00$ per 100 , postpaid. Not postpaid, 50 for 95c; $\$ 1.75$ per 100 , $\$ 10.00$ per 1,000 .

\section{Broccoli}

Calabrese Green Sprouting A distinct variety being somewhat like Cauliflower. Having the mild flavor of vegetable. The Plant grows about 2 feet high producing a medium size central head. After the head is fully developed, it should be cut and uscd. Clusters of smaller heads or green sprouts are then produced throughout the season which should bc cut and used regularly. It is easy to grow and may be planted from Spring to Fall. Pkt. 10c; oz. 65c; 1/4 lb. \$2.00; lb. $\$ 7.25$, postpaid.

\section{Brussels Sprouts}

A very esteemed member of the cabbage family. Brussels Sprouts resemble miniature cabbage, which form and grow closely around the stalks of the plant, a small head being formed at each leaf joint. The leaves should be broken down in the fall to give the little heads more room to grow. Brussels Sprouts are of a delicate flavor and make a deliciously appetizing dish. The seed should be sown in a plant bed and transplanted to rows when ready any time from April to August, 2 feet apart, with plants 18 to 24 inches apart in the row. Cultivate and treat in all respects like winter cabbage or kale. One ounce of seed will produce about 1,500 plants. Pkt. $10 \mathrm{c} ;$ oz. 20c; 1/4 lb. 60c, postpaid,

\section{Rhubarb}

For the home garden it will be found far more satisfactory to grow Rhubarb from the Roots, rather than the Seed. These can be set out in this section in November and early December, March and April. Rhubarb should be set only in rich, moist soil, well workcd and hcavily fertilized. A trench should be dug about 2 feet deep, manured abundantly, roots placed about 4 feet apart and well covered with coarse litter or manure. Rhubarb should be grown only in well shaded situations. It is best not to gather many of the stalks the first season, but after the first year they may be used freely and will last for years.

Rhubarb Roots 20c each; $\$ 1.50$ doz., postpaid. Not postpaid, 15c each; $\$ 1.25$ doz.; $\$ 8.00$ per 100 .

Rhubarb Seed VICTORIA-Very large; the best variety for general use. Seed may be sown from March to June, $1 / 1$ lb. 45 , postpaid. 


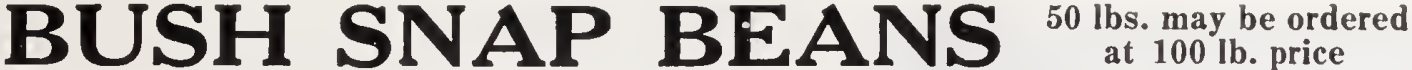

CULTURE.-These can be planted any time from April 1st (or after danger of frost is past) to September 1 st. To have a continuous supply, plant them at intervals of every two weeks. They thrive best in good, light, loamy soil, as they have a tendency to rust if planted in stiff or heavy soil. Plant in rows $2 \frac{1}{2}$ to 3 feet apart and 3 to 4 inches apart in the rows. Cover $1 \frac{1}{2}$ inches deep. Give only light cultivation after plants are 6 inches high. About 1 pound is required to plant 50 feet of row and from 60 to $100 \mathrm{lbs}$. to the acre.

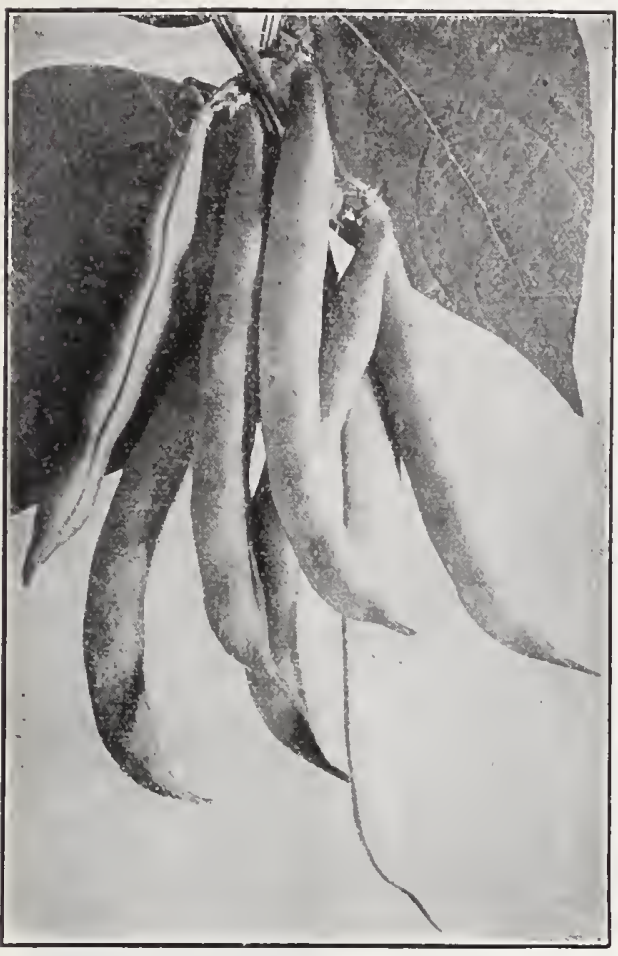

Burpee's Stringless Green Pod

Stringless Red Valentine This was bred from Valentine, so popular at one time, and while it had many good qualities was losing its popularity on account of being very stringy. This new variety retains all of the good qualities of the old favorite and besides is completely stringless, the quality so desired in a snap bean. The pods are thick and fleshy, of good quality and flavor. They are ready to pick in seven weeks after planting.

Bountiful This is one of the first early varieties and Bountiful continues bearing through a longer season than most other sorts. The pods are deep green, extra long, rather flat, thick and meaty, with very few strings, and if used when very young is entirely free from strings and considered the best flat snap, pods being exceptionally brittle and tender.

Full Measure Stringless ${ }^{A}$ fine medium early splendid quality. The pods are long, thick, firm, and tender, entirely stringless, and remain fit for use a number of days after maturity. Very popular in some sections.

Stringless Refugee A new variety of round green what earlier than the Refugee or 1,000 to 1 and absolutely

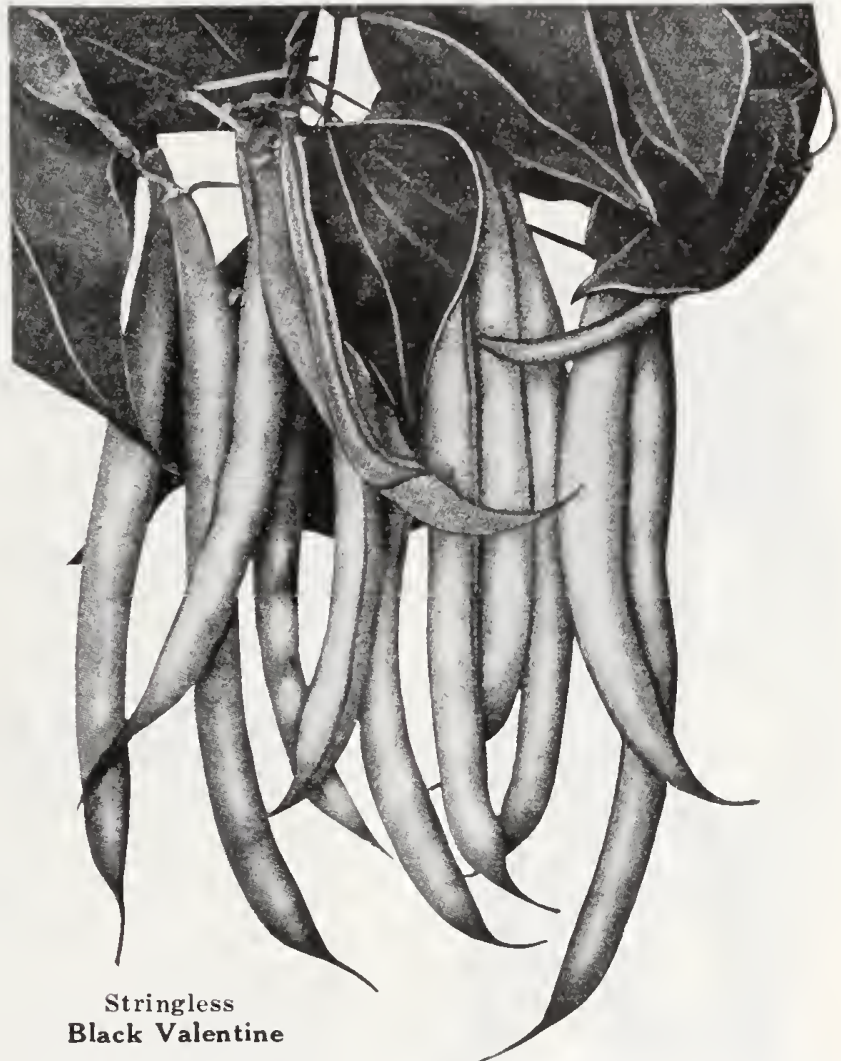

stringless. This bean has all of the good points of the old Refugee, and in addition is entirely stringless and tenderer, and is considered far superior to that variety.

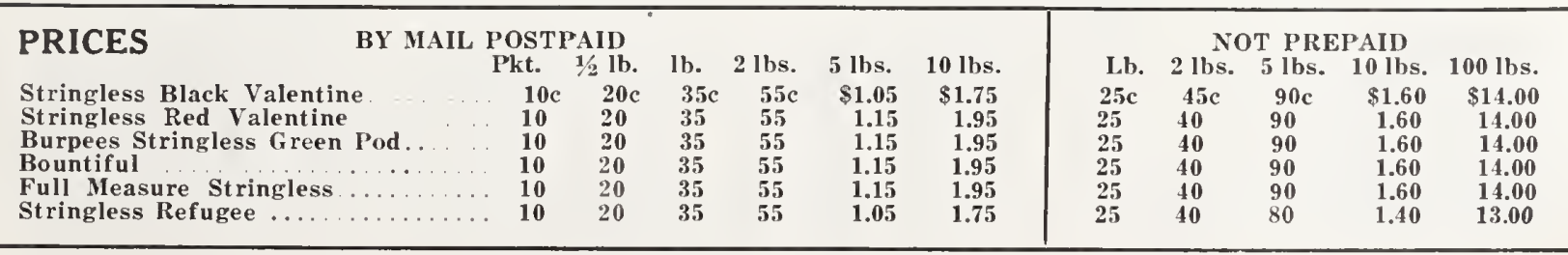




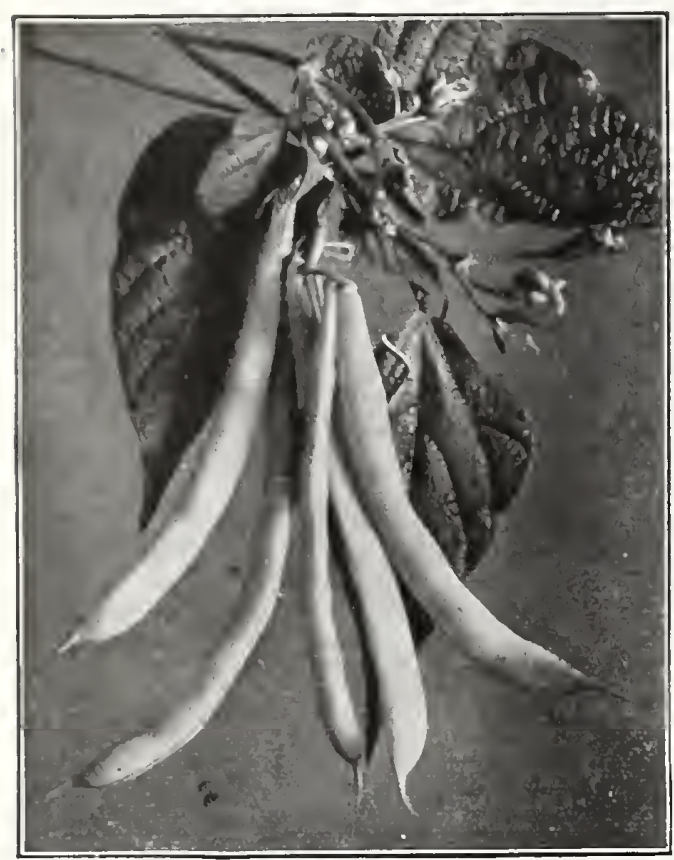

Pencil Pod Black Wax

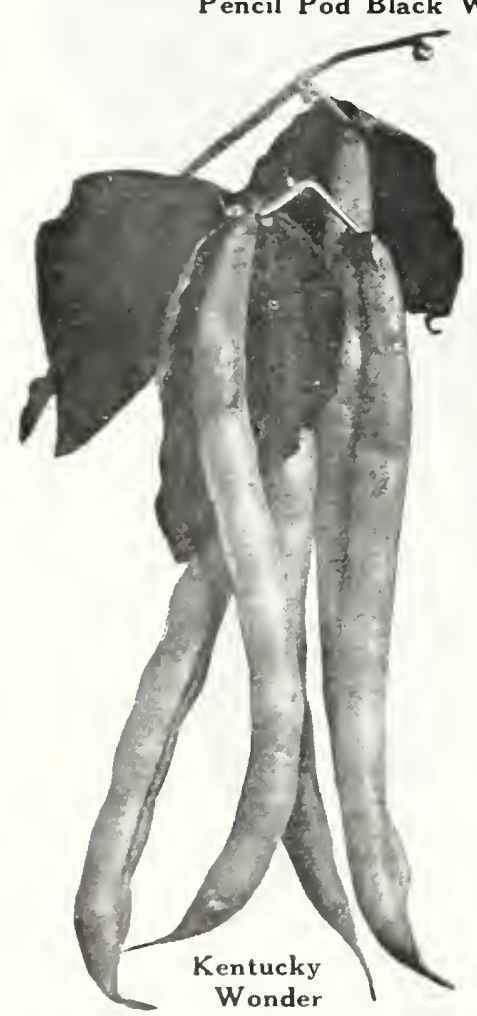

Tennessee Green Pod The most popular variety in many largest and longest pods of all Dwarf sorts, often 6 to 7 inches long, somewhat irregular in shape, and flat. The plants are large and rather spreading, yielding heavily.

Giant Stringless Green Pod A good variety for either home earliest and the quality is good. Has round pods 5 to 6 inches long, entirely stringless.

\section{Wax or Yellow Podded Varieties}

Pencil Pod Black Wax This is the most popular Wax Bean Por home use where highest quality is desired. It is early, hardy and productive and continues bearing through a long season. The pods are round and of a bright clear yellow, brittle, tender, entirely stringless, free from fibre and of a rich buttery flavor.

Rustless Golden Wax A second early or riety. The plants are strong, vigorous and entirely free from rust. The pods grow about 5 inches long oval-flat, a handsome light yellow, entirely stringless, teuder and brittle.

\section{Pole Snap Beans- Green Podded}

CULTURE.-These are not as hardy as the Bush Beans and should not be planted until after danger of frost is past and the ground becomes thoroughly warm, about May 1st, and from then until July. Plant in rows 4 feet apart and in raised hills 4 feet apart in the rows. Plant about 5 beans in a circle around the hill, cover $1 \frac{1 / 2}{2}$ inches, and when 6 inches high thin to 3 plants. Before planting fix firmly in the center of each hill a pole 5 to 8 feet high. About $1 \mathrm{lb}$. is required to plant 100 hills; $30 \mathrm{lbs}$. to the acre.

Kentucky Wonder The most popular of the Pole $\frac{1}{\text { to } 70 \text { days from planting and if kept closely picked will }}$ continue in bearing until frost. It is enormously productive. The Beans are a bright green, grow in clusters and are 6 to 10 inches long, nearly round, while slightly stringy are very crisp and tender, particularly if used when young. White Creaseback or Cornfield A me diu m seeded round green pod Pole Bean, a prolific yielder of excellent quality. Beans are borne in clusters, very fleshy and brittle with few strings. It is also sometimes called White Cornfield Bean so popular everywhere.

\section{Bush Lima Beans 50 lbs. may be ordered at $100 \mathrm{lb}$. price.}

CULTURE-Plant after danger of frost is past in April, May or June in rows 3 feet apart, and place beans eves downward, 15 inches apart in the row, covering them $11 / 2$ inches. About 1 pound is required for 100 feet of row: 30 lbs. to the acre. If planted in hills make the hills 2 or 3 feet apart in rows 3 feet apart, planting 4 or 6 beans in a hill. Keep well cultivated but never work them when the leaves are wet.

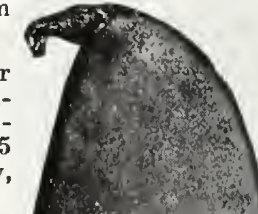

Fordhook A most excellent Bush Lima Bean. The plants are sturdy, grow strictly Frakt 18 to 20 inches high, holding the beans well off the ground, bearing large pods with 4 or 5 very large thick white oval-shaped beans crowded into the pod. The beans surpass by far all other limas in flavor and tenderness. We consider this decidedly the best of the Large Size Bush Lima Beans either for private or market gardeners, and it is from 4 to 6 days earlier than other beans of this class.

See Next Page for Prices

\section{PRICES}

Tennessee Green Pod

Giant Stringless Green Pod.

Pencil Pod Black Wax

Rustless Golden Wax.

POLE SNAP BEANS

Kentucky Wonder

White Creaseback or Cornfield
BY MAIL POSTPAID

Plkt. 1/2 lb

$\$ .10 \quad \$ .20$

.10 .20

$.10 \quad .20$

$.10 \quad .20$

$10 \quad 20$

$.10 \quad .20$ lb.

$\$ .35$

.35

.35
.35

.35 lbs.

$\$ .60$

.55

.60

.60

.55

.35
.60
5 lbs. 10 lbs. lb.

$\$ 1.20 \quad \$ 2.15 \quad \$ \quad .25$

$\begin{array}{llll}1.15 & 2.00 & .25\end{array}$

\begin{tabular}{ll|l}
1.20 & 2.05 & .25
\end{tabular}

\begin{tabular}{ll|l}
1.20 & 2.05 & .25
\end{tabular}

1.15

1.20

1.95
2.05

NOT PREPAID

2 lbs. 5 lbs. 10 lbs. $100 \mathrm{lbs}$

$\begin{array}{lllll}.45 & \$ .95 & \$ 1.70 & \$ 15.00\end{array}$

$\begin{array}{rrrr}.40 & .90 & 1.60 & 14.00\end{array}$

$\begin{array}{llll}.45 & .95 & 1.70 & 15.00\end{array}$

$\begin{array}{llll}.45 & .95 & 1.70 & 15.00\end{array}$ 
Wood's Prolific Since its introduction, this variety has steadily grown in favor. While similar in character and making a much larger growth, the beans being larger and thicker.

Henderson's The original well known small bush lima. It is the earliest bush variety, and while the beans are small it Henderson's is very prolific and continues bearing until frost. Makes a good dry bean for winter use and still a favorite with many gardeners.

\section{POLE LIMA BEANS}

CULTURE-Plant after danger of frost is past in April and May in raised hills 3 feet apart in the row and rows 4 feet apart. Plant 5 beans in a circle around the hill, with the eyes of the seeds downward and cover $11 / 2$ inches. When 6 inches high thin to 3 plants to the hill. Fix firmly in the center of each hill a pole 5 to 8 feet high, and when the plants show runners help the vines to start by twining them around the pole from right to left. If it is not convenient to get poles, coarse wire netting makes an excellent support, and many gardeners now use this method, supporting it with strong stakes. Pole Beans are rather more troublesome to grow than the bush, but they bear more abundantly and continue bearing over a longer time. If gathered regularly they continue bearing until killed by frost. They require only light cultivation after

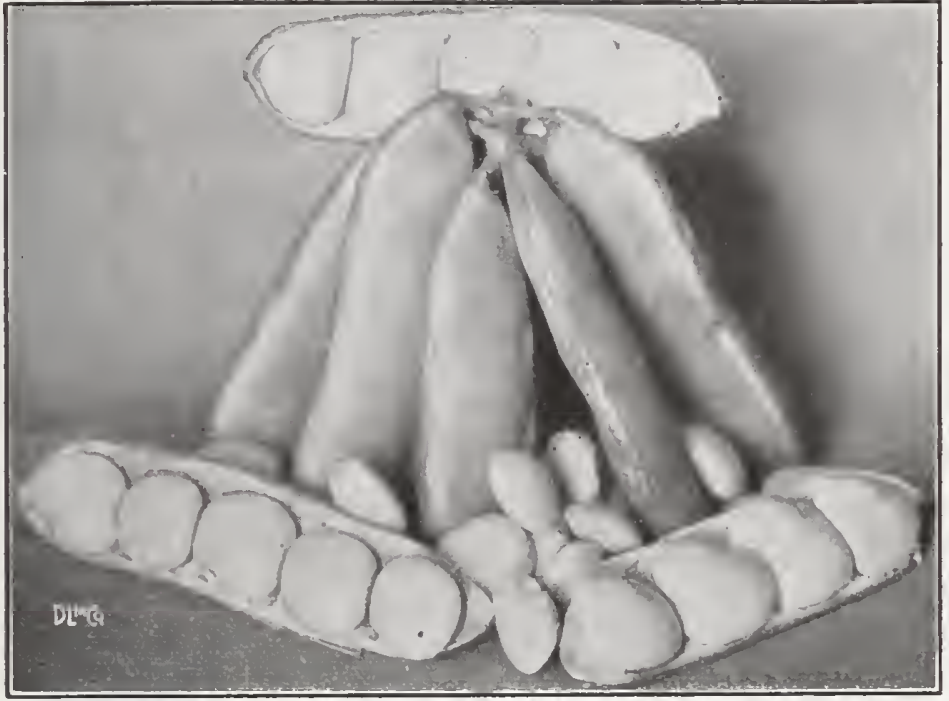

Prolific Bush Lima the plants are 8 inches high. $1 \mathrm{lb}$. of the small size beans will plant about 100 hills; 15 lbs. to the acre. Of the large size $1 \mathrm{lb}$. will plant about 50 hills; 40 lbs. to the acre.

D. \& B.'s Improved Lima Iany years and breeding from the small pole lima has produced this bean, which is far superior to its parent. It is not only slightly earlier, but considerably larger than the small lima and the beans are of the same good quality. Wuch more productive than the large lima and continues bearing through a long season. The pods grow in clusters and are easily gathered. We recommend this as a decided improvement in pole limas. grower, earlier and more productive than the large lima, yielding abundantly until frost. Large White Lima The well known large late variety. A vigorous grower with greenish white. While not as productive as the smaller bean, on account of its excellent flavor it is still a favorite with many home gardeners.

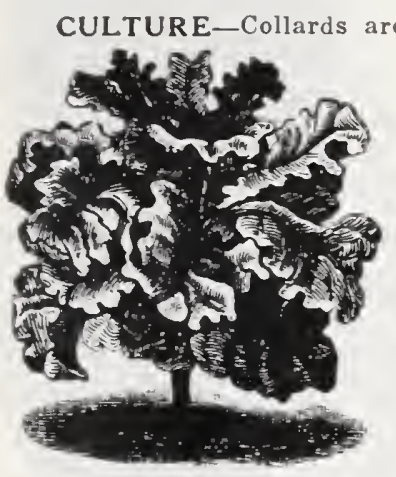

Collard

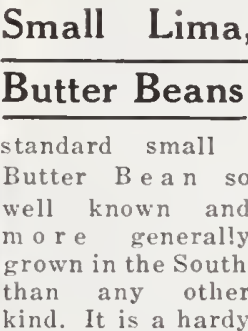
kind. It is a hardy and vigorous

\section{Collards}

grown very largely in the Southern States, where they are used as a substitute for cabbage, as they are easier to grow, are also hardier and thrive better on poor soil, and are not as susceptible to insects. Collards are frequently sown in the early spring months, but seem to do best when sown in June, July or August. Transplant and cultivate like late cabbage, and keep well worked. It is said the flavor is improved by a touch of frost, and it makes a splendid dish for fall and winter use. One ounce of seed produces about 1,500 plants.

North Carolina Short Stem The favorite variety it thrives and flourishes bountifully where it would be difficult to raise cabbage successfully. It has short stems, large spreading leaves, very hardy, withstanding well the droughts of summer and becomes peculiarly sweet and tender when touched by frost. Oz. $10 \mathrm{c} ; 1 / 4 \mathrm{lb} .30 \mathrm{c} ; 1 \mathrm{lb}$. $\$ 1.00$, postpaid.

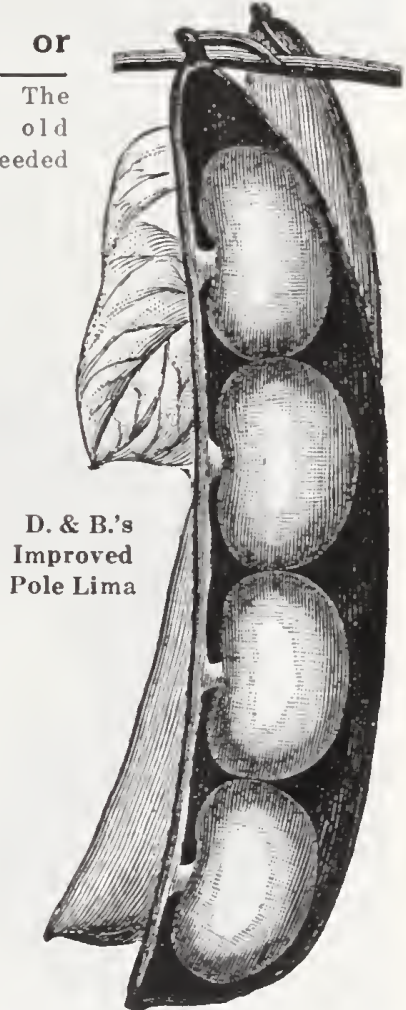

Georgia, or Southern An old and popular variety which thrives on the poorest soils and withstands the most severe winters in the South. Oz. 10c; 1/4 lb. 25c; lb. 75c, postpaid.

\section{PRICES}

Fordhook Bush Lima Wood's Prolific Bush Lima

Henderson's Bush Lima.. D. \& B.'s Improved Pole Lima Small Pole Lima

Large White Pole Lima
BY MAIL POSTPAID

\begin{tabular}{rrrrrr|} 
Pkt. & $1 / 2$ lb. & lb. & 2 lbs, & \multicolumn{2}{c}{5 lbs, 10 lbs. } \\
$\$ .10$ & $\$ .25$ & $\$ .45$ & $\$ .75$ & $\$ 1.65$ & $\$ 2.95$ \\
.10 & .25 & .40 & .65 & 1.35 & 2.35 \\
.10 & .20 & .35 & .60 & 1.20 & 2.05 \\
.10 & .25 & .40 & .65 & 1.35 & 2.35 \\
.10 & .20 & .35 & .60 & 1.20 & 2.05 \\
.10 & .25 & .40 & .65 & 1.35 & 2.35
\end{tabular}

\begin{tabular}{|c|c|c|c|c|}
\hline \multicolumn{5}{|c|}{ NOT PREPAID } \\
\hline & 2. lbs. & 5 lbs. & $10 \mathrm{lbs}$. & $100 \mathrm{lbs}$ \\
\hline 35 & $\$ .60$ & $\$ 1.40$ & $\$ 2.60$ & \\
\hline .3 & .50 & 1.10 & & \\
\hline .2 & .45 &. & & \\
\hline .3 & .50 & 1.10 & 2. & \\
\hline & .4 & .9 & & \\
\hline 3 & .5 & 1.10 & 2.00 & \\
\hline
\end{tabular}




\section{B F T 5 lbs. may be ordered at $10 \mathrm{c}$ per $\mathrm{lb}$. less than lb. price.}

CULTURE-For very early crop the seed should be sowed in hotbeds or started in boxes in the house in January and February. After danger of frost is past, transplant and set them in rows 2 to 3 feet apart, and 6 inches apart in the rows. Or they can be sown outside from March to July, as desired, for medium, early or late crop, in drills, covering 1 inch and plants thinned to 6 inches. Beets should be grown in light, clean, deep soil, and kept well cultivated. The leaves of young beet plants make excellent salad or "greens." Two ounces of seed will sow 100 feet of row and about 7 lbs. are required for an acre. It is best to soak the seed overnight before planting.

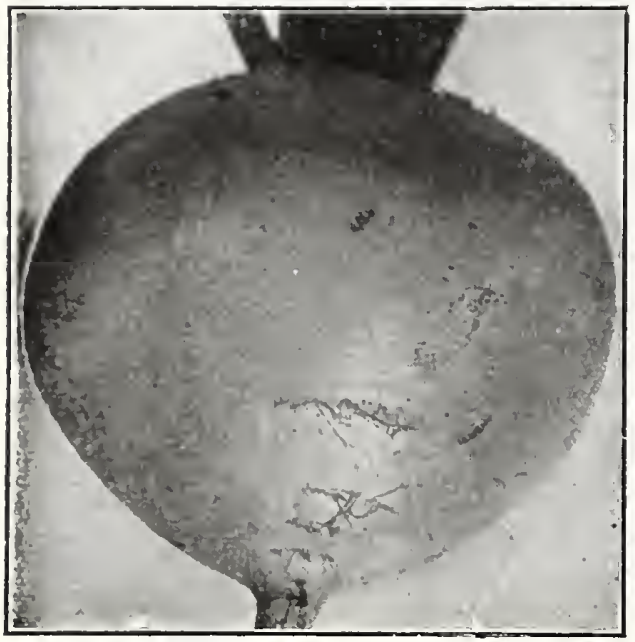

Detroit Dark Red
Early Wonder This is said to be a perfect table beet; it is medium early, coming in several days later than the extra blood red, has slim tap root, fine grain, tender and sweet. Never gets Plt. 10c; oz. 15c; 1/ lb. 30c; lb. \$1.00, postpaid.

Crosby's Improved Egyptian A very early strain of the old lattened globe shaped, of a bright red color Vord Egyptian. The roots are is ready for use earlier than most other varieties. This is the market gardener's favorite beet, being a money maker on account of its extreme earliness. Has small tops. Pkt. 5c; oz. 10c; 1/1 lb. 25c; lb. 85c, postpaid.

Detroit Dark Red One of the very best varieties for the home garden or market. It is globe shaped, medium size, uniformly smooth, tender and sweet. The skin is of the darkest red color of all globe shaped beets. A good variety for both summer and fall use. Pkt. 5c; oz. 10c; $1 / 4$ lb. 25c; lb. 85c, postpaid.

Extra Early Eclipse An extra early, rapid-growing beet, of medium very sweet, crisp and tender. Has small tops. An extra fine beet for early or second early use. Pkt. 5c; oz. 8c; 1/4 lb. 25c; lb. 75c, postpaid.

Improved Early Blood Turnip An improved strain of the old standard, well known table beet. The roots are Improved Early Blood Turnip nearly round, slightly flattened, of a deep blood red color, fine form and flavor. While not as early as the Eclipse and Crosby's Egyptian, it is still the favorite with many home gardeners for medium early and later use. Pkt. 5c; oz. 8c; 1/4 lb. 25c; lb. 75c, postpaid.

Swiss Chard or Silver Leaved Beet This kind of beet is grown exclusively for Swiss Chard or Silver Leaved Beet This tender leaves and stalks as it does not make an edible bulbous root. The leaves being far superior to any other beets for use as

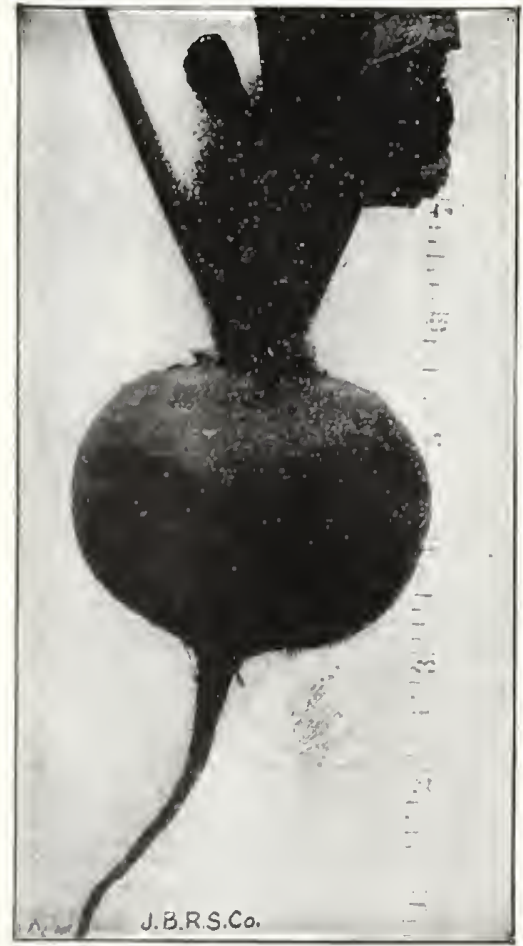

Crosby's Egyptian "Greens." Prepare and cook the leaves just as you do Spinach, Kale and Turnip salad, and the stems like Asparagus. There is a delicious delicate flavor in Swiss Chard not found in turnip salad or Kale. The leaves grow from 20 inches to 2 feet in length. The plant is almost perpetual if kept trimmed. This is well worthy of a place in every home garden. Plant from early Spring until July. Pkt. 5c; oz. 8c; 1/4 lb. 25c; lb. 75c, postpaid.

\section{Stock Beet or Mangle}

CULTURE-These can be sowed in April, May and June, drilled in rows 3 feet apart and the plants thinned to 6 or 8 inches apart in the row. They should be well cultivated until they get well started. Sow one ounce to about 75 feet of row; six pounds to the acre. Stock Beets grow to an enormous size on good land and make splendid food for stock of all kinds.

Mammoth Prize Long Red This is by far and satisfactory of the mangles to grow. It is hardy and produces large crops with little care, producing forty tons or more to the acre on good land and thorough cultivation. The roots are uniformly straight and well formed and grow to a large size well out of the ground, some of them weighing 20 lbs. or more. It is a milk producer and makes fine rich food for stock and poultry. Oz. 8c; 1/1 lb. 20c; lb. 60c, postpaid.

\section{Waterproof Paper Pots}

Used for starting plants early in the home or hothouse. The ideal Pot for transplanting and shipping plants. Well made and durable.

21 inch size $60 \mathrm{c}$ per $100, \$ 1.50$ per 1,000 $21 / 2$ inch size...70 per $100, \$ 5.00$ per 1,000 3 inch size...8.8c per $100, \$ 7.00$ per 1.000 Postage extra 10c per 100.

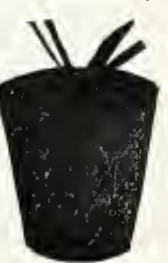

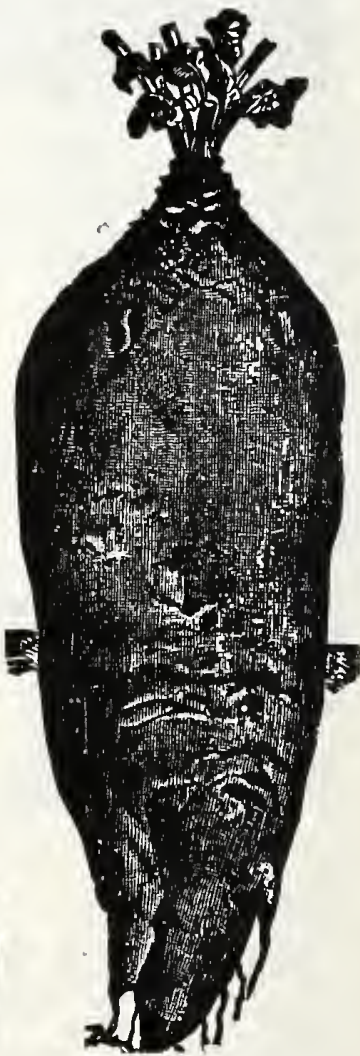

Mammoth Prize 


\section{CABBAGE}

CULTURE-To make an early crop of Cabbage the seed can be sowed in hotbeds or in boxes in the house in January, February and March, or for later crop can be sowed outside from April to June, but to make the earliest Spring Cabbage the seed should be sowed outside about September 15th, and then transplanted in November, where they are to remain. For late crop for winter use sow the late varieties from May 15 th to August, transplanting when large enough. Cabbage should always be grown in good rich soil that has been deeply worked and well fertilized with stable manure or a fertilizer containing a liberal supply of ammonia. Set in rows 3 to $4 \mathrm{feet}$ apart, with plants 16 to 24 inches apart in the row, according to the variety of cabbage, whether of large, medium or small size growth. One ounce of seed will produce about 1,500 plants.

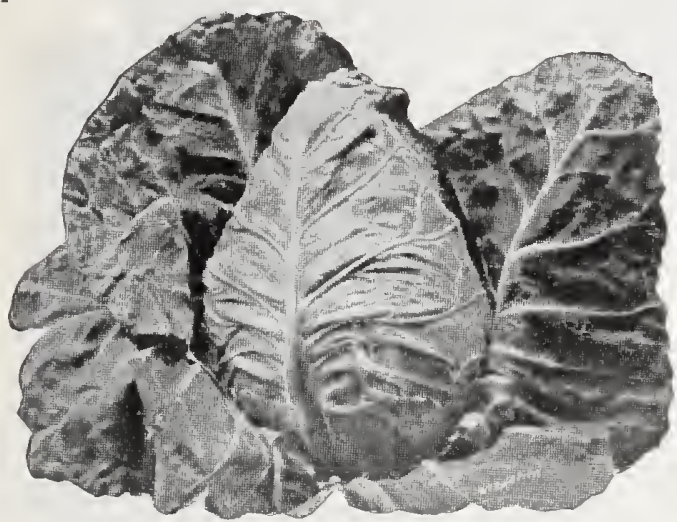

D. \& B.'s Early Jersey Wakefield
D. \& B's. Early Jersey Wakefield for both market cardeners and home use. Our strain of this cabbage is superior to most stocks generally offered as it has for years been carefully bred and grown for us by the most reliable cabbage seed growers in this country. It cannot be improved upon, and is just what is wanted by the most critical truckers and gardeners. They are uniform in size and make firm conical or pointcd heads with few outer leaves. Unquestionably this is the best first early cabbage for either the home garden or market. ['kt. $10 \mathrm{c} ; 0<.25 \mathrm{c} ;{ }_{4}^{1 / 4}$ lb. 75c; lb. $\$ 2.50$, postpaid.

Large or Charleston Wakefield What we have said about strain of our Jersey Wakefield is equally true of our Charleston. This variety is a week or ten days later than our Jersey Wakefield, is fully as solid, but with less pointed heads and grows from one-third to onehalf larger. It is exceedingly hardy and this, together with its considerably larger size, has made it a most popular sort with gardeners to follow the Jersey Wakefield. Pkt. 10c; oz. 25c; $1 / 4$ lb. 75c lb. $\$ 2.50$, postpaid.

\section{Copenhagen Market}

A very early large flat-head, short stem Wakefield cabbage, maturing with the Charleston solidity and compact growth of its leaves, it has become a favorite variety for second early use. Pkt. 10c; $0 \mathrm{z} .30 \mathrm{c} ; 1 / \mathrm{lb} .90 \mathrm{c} ; 1 \mathrm{~b} . \$ 3.00$, postpaid.

Succession A sure heading second early flat-head Cabbage about two weeks later than the Charleston Wakefield. It is equally adapted for the fall crop as for late summer use. It is a vigorous strong growing variety. The heads are large, very firm and of excellent quality. A most popular cabbage with our market gardeners Pkt. 5c; oz. 20c; 1/t lb. 60c; lb. \$2.00, postpaid.

Early Flat Dutch An old standard and a good second early sort. what flattened and very solid. Preferred by many gardeners for home use. Pkt. 5c; oz. 20c; i, lb. 60c; lb. $\$ 2.00$, postpaid.

All Seasons A very desirable cabbage adapted to Autumn as well

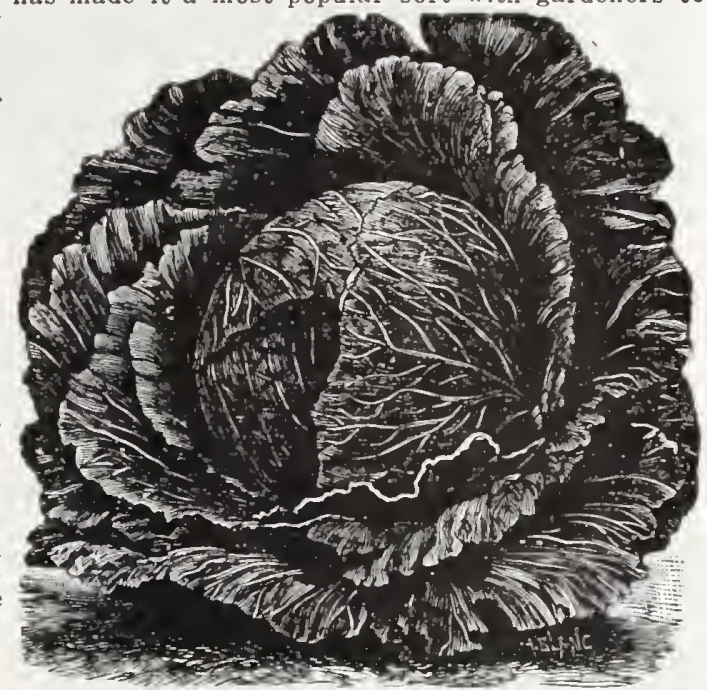

Succession

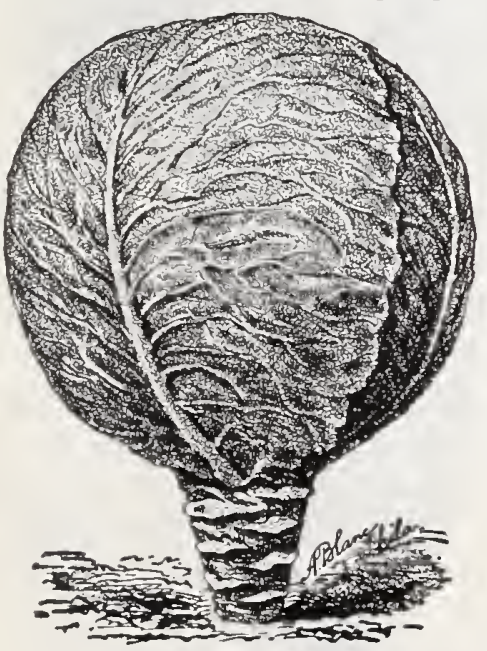

Danish Ballhead

header. The heads are large, nearly round or somewhat flattened, very solid and of excellent quality. It is remarkable for its ability to stand the hot sun and dry weather and is a splendid keeper. Pkt. 5c; oz. 20c; 1/ lb. 60c; lb. \$2.00, postpaid.

Danish Ballhead One of the very best winter cabbages, has a short stem, large heads, and is the hardest and heaviest cabbage for its size we have ever known. It is very hardy, resisting droughts and wet weather far better than any other kind. It matures quickly and can be planted later than most other varieties. It is one of the finest keepers, an ideal cabbage for storing for winter use. Pkt. 10c; oz. 30c; 1/4 lb. 80c; lb. \$2.75, postpaid.

Autumn King This is the largest of the cabbage family, the heads being unwhat frilled or scolloped. The heads are very solid and keep well. A variety for which we have always had a good demand and it is a really good sort for fall and winter use. Pkt. $10 \mathrm{c} ; 0 \mathrm{z} .25 \mathrm{c} ; 1 / 4$ lb. 60c; lb. $\$ 2.00$, postpaid. D. \& B's. Late Flat Dutch This has long been a favorite cabbage with hardy, vigorous, though, rather a slow-growing variety, but a very sure heading sort. Has short stems with very large broad spreading leaves. The heads are uniformly large, distinctly flattened on the top, very solid and of excellent quality. Considered by many as the standard large late cabbage for home use. Pkt. 5c; oz. 20c; $1 / 4$ lb. 60c; lb. $\$ 2.00$, postpaid. 
Golden Acre An early round headed cabbage, growing some- what like the Copenhagen Market, though it matures from 8 to 10 days earlier than that variety. The heads are perfectly round, average about $5 \mathrm{lbs}$. each, very solid and of good quality. Owing to its earliness, uniformity of size and actractive appearance, it is proving a profitable variety for market gardeners. Plit. $10 \mathrm{c} ; 0 z .35 \mathrm{c} ; 1 / \mathrm{lb} . \$ 1.15 ; 1 \mathrm{~b}$. \$4.00, postpaid.

\section{Drumhead Savoy Considered by many the best late cab-} globe shape, firm and of medium size. The leaves are densely curled and crimped. It is of a very delicate flavor, very tender, being almost like cauliflower, especially after it has been touched by frost. A splendid late cabbage for family use which should generally be sowed during mid-summer, as it will not head up well during hot weather. Pht. $10 \mathrm{c} ; 0 z$. 25c: 1/ lb. 70c; lb. $\$ 2.50$ postpaid.

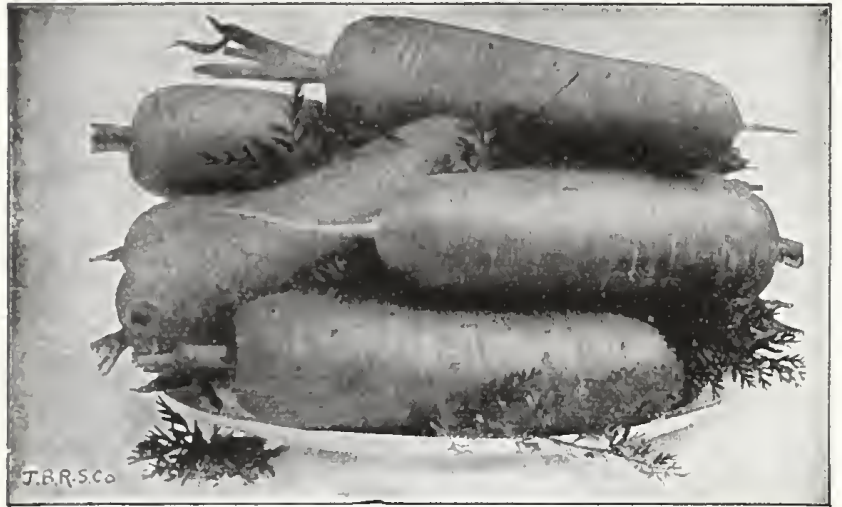

Chantenay

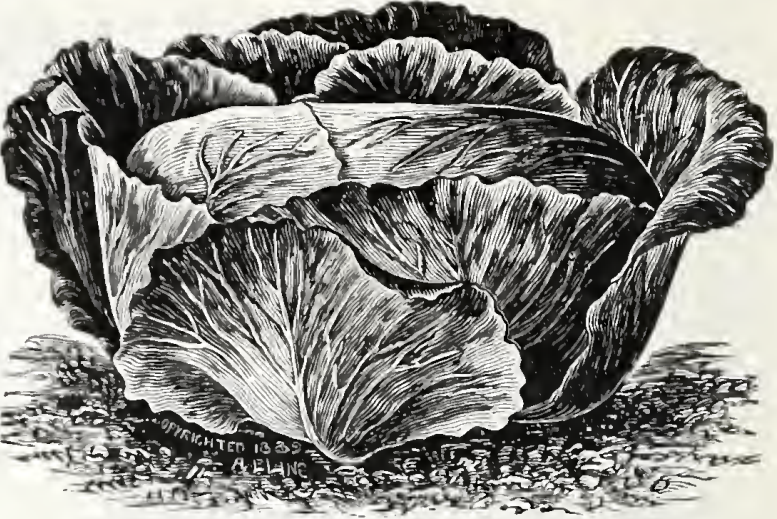

Autumn King

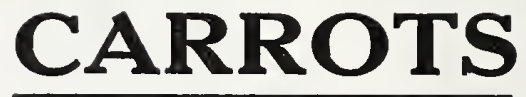

CULTURE-For early use sow from March to June in drills 12 inches apart, covering the seed firmly about onehalf inch. When the plants are large enough, thin to 4 or 5 inches apart. They thrive best in light, loamy, deep, rich soil. Carrot seed are very slow in germinating, and it is well to soak the seed thoroughly before sowing and press the soil firmly after sowing to prevent evaporation. For late crop, sow from July to August. To keep Carrots in winter, pack well in clean dry sand and place in a dry dark cellar. Sow 1 ounce of seed to 100 feet of row; about $4 \mathrm{lbs}$. to the acre.

Chantenay A most excellent medium early half long or stump rooted It is smooth, of a deep orange red color. The flesh is very crisp, tender and sweet. A splendid carrot for either home use or bunching for market. l'kt. $5 \mathrm{c} ; 0 \mathrm{z} .10 \mathrm{c} ; 1 / \mathrm{l}$ lb. $25 \mathrm{c}$; 1b. $85 \mathrm{c}$, postpaid.

Improved Long Orange The standard carrot for the main crop, a deep orange color, long, smooth and tapering, often growing 12 inches in length. I'kt. 5c;0\%.10c; 1/4 lb. 25c; lb. 80c, postpaid. Scarlet Intermediate A favorite medium early carrot, bright about 6 inches long almost without core. Very popular with market gardeners as a general purpose Carrot. Pkt. 10c; oz. 20c; 1/ lb. 40c; 1b. $\$ 1.25$, postpaid.

Danvers Half Long A half-long deep orange colored carrot, largeadaptability to all kinds of soil. A desirable second early carrot for the home garden or field culture. Grows about 7 inches long making an attractive root of good quality. Pkt. $5 \mathrm{c} ; 0 z .10 \mathrm{c} ; 1 / \mathrm{llb}$. 25c; lb. 85c, postpaid.

\section{CELER Y}

CULTURE-Sow in hotbeds or in seed boxes in the house in February or March. Keep well watered and transplant from July to September 15th to rich, moist, mucky soil in rows 12 to 18 inches apart, with plants 6 inches apart in the row. When about 4 inches high clip off the tops to make the plants stocky. Supply abundance of moisture. As the plants grow heap up the earth around the stalks to whiten them. To protect from severe winter weather, cover the rows with straw and lay boards on the top, or bank the rows with boards when 10 inches tall. One ounce of seed produces 1,000 plants. As celery seed germinate slowly it is best to soak the seed for 24 hours before sowing.

Winter Queen We consider this the best winter celery, it blanches did keeping variety. Pkt. 10c; oz. 25c; 1/4 lb. 70c; lb. $\$ 2.50$, postpaid. Not postpaid, lb. $\$ 2.40$.

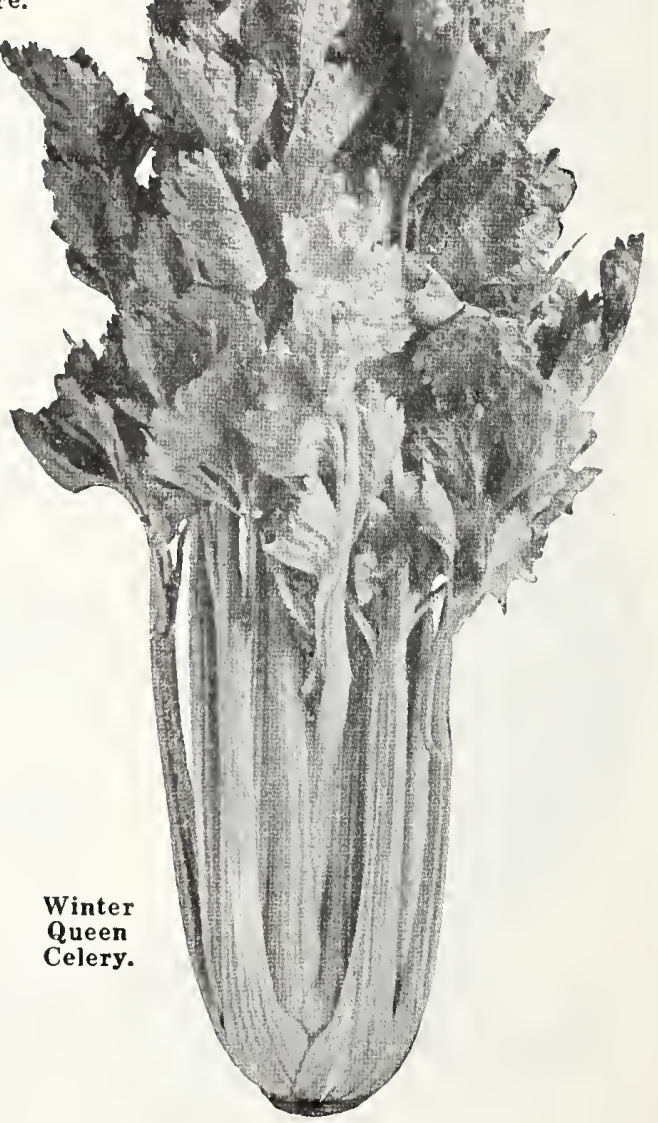



Golden Self-Blanching Not as early as the White Plume, but is of a heavier and more compact growth. Its stalks tender and free from stringiness. Pkt. $10 \mathrm{c} ; 0 \mathrm{z}, 45 \mathrm{c} ; 1 / 4 \mathrm{lb} . \$ 1.50$.

White Plume One of the best for early use; handsome, good quality and blanches easily. Turns white naturally on Giant Pascal Thick, solid stalks, golden hearts; blanches quickly; keeps well; of a good flavor; one of the most popular varieties. 1'kt. $10 \mathrm{c} ; 0 z .25 \mathrm{c} ; 1 / 4$ lb. $75 \mathrm{c}$; lb. $\$ 2.50$, postpaid.

\section{GARDEN CORN 50 ills, may be ordered}

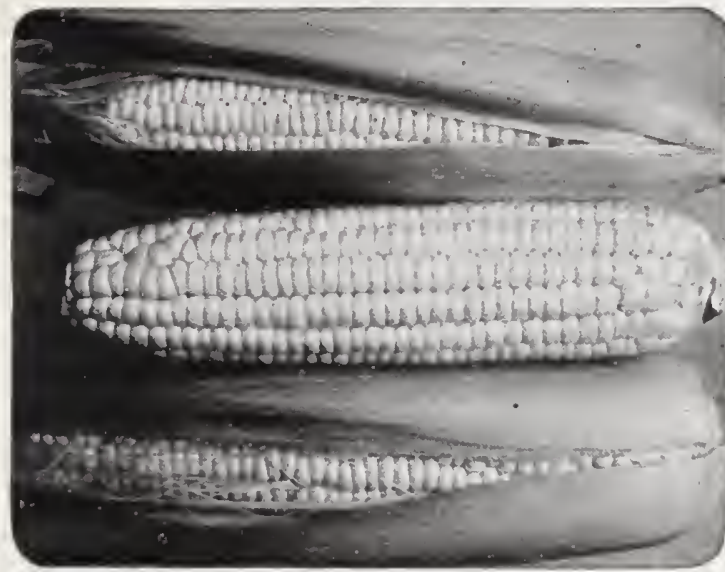

Stowell's Evergreen

CULTURE-Plant 3 or 4 grains $1 \frac{1}{2}$ inches deep, 2 feet apart in rows 3 to 4 feet apart, according to the size and variety of the corn. When plants are 4 inches high thin out to 2 plants to the hill. For very early corn the hardiest and earliest varieties can be planted the latter part of March, if the weather is mild, but sweet corns are tender and should not be planted until April, or until the spring weather opens and the ground becomes thoroughly warm, as sugar corn has a tendency to rot in the ground if planted too early, or during a continued cool or rainy spell of weather. It should be planted at intervals of every two weeks until July or August in order to have roasting ears for use during the entire season. Give frequent and thorough, but shallow cultivation until the tassels appear. One-half pound will plant 150 feet of row; $10 \mathrm{lbs}$. to the acre.

Adam's Extra Early This well known variety is the earliest and hardiest White Garden Corn. Because of this it is largely grown by market gardeners in the South for the earliest crop. The ears are short and thick, and while rather small they are usually ready about 7 weeks after planting. It can be planted close as the stalks grow only about 4 feet high. This variety should be grown only on good land well fertilized.

Adam's Early This is about a week or 10 days later than the ears, measuring about 8 inches in length. The stalks are small, growing about 6 feet high. This is also a hardy corn and can be planted earlier than the sweet corns. While not as early as the Adam's Extra Early, it is preferred by many gardeners on account of the larger size and more uniform shape of the ear.

Improved Adam's Early This is an improvement on the old Standard Adam's Early, the ears being larger, measurplanted early.

Trucker's Favorite A splendid second early hardy White Corn coming in about a week later than the Improved Adam's Early. It has deep white soft grains, tender and sweet, and makes a good size roasting good variety to plant late to mature corn quickly for stock feeding or for making meal. It may be planted as late as July 15 th, and will then make good corn before frost.

\section{Sweet, or Sugar Corn}

Golden Bantam This is a distinct variety and is really a superb Goldy sweet corn. It has golden yellow grains tender, exceptionally rich and pleasing with a flavor all its own. It is hardy and can be planted earlier than most $s$ weet corns. The ears are eight rowed 6 to 7 inches long, generally 2 to the stalk. We consider this the best early sweet corn for the family garden.

Country Gentleman A favorite variety for mid-season and late crop, both for table use and canning purposes. Has small white cob thickly covered with irregular rows of very long slender white grains of excellent quality. The ears are 8 to 9 inches long, with 2 or more to the stalk, which grows 6 to 7 feet high, considered by many the best of the later varieties. Keeps tender and fit for use through a long season.

Early White Evergreen This is a high bred pure white typc green, though considerably earlier and of a distinctly improved

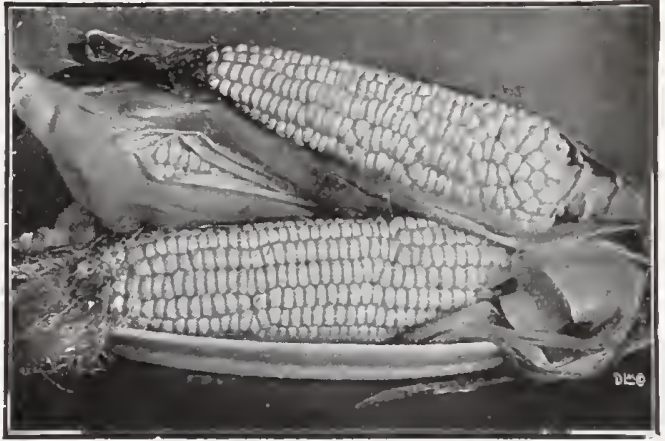

Golden Bantam strain. It has all the sweetness and tenderness characteristic of the old stock. When in the green state, both the cob and kernel are white as snow. It has decp grains of the very best quality and remains tender and fit for use through a long season. It is an excellent variety both for table use and canning, and one of the best for the home garden.

\section{PRICES}

Adam's Extra Early

Adam's Early

Improved Adam's Early

Trucker's Favorite

Golden Bantam

Country Gentleman

Early White Evergreen

Stowell's Evergreen
BY MAIL POSTPAID

$\begin{array}{rr}\text { Pkt. } & 1 / 21 \\ \$ .10 & \$ .2 \\ .10 & .2 \\ .10 & .2 \\ .10 & .2 \\ .10 & .2 \\ .10 & .2 \\ .10 & .2 \\ .10 & .2\end{array}$

\section{(1)}

lb. $\quad$ lb. 2 lbs. 5 lbs. 10 lbs.

$.20 \quad \$ \quad .30 \quad \$ .50$

$20 \quad .30 \quad .45$

$.20 \quad 30$

$.20-30$

$.20 \quad .35$

$20 \quad 35$

$20 \quad .35$

$.20 \quad .35$
.50
.45
.45
.50
.60
.60
.60
.55

$.55 \quad 1.20$

\begin{tabular}{rr|r}
1.00 & $\$ 1.70$ & $\$ .2$ \\
.95 & 1.50 & .2 \\
.95 & 1.50 & .2 \\
.90 & 1.50 & .2 \\
1.20 & 2.05 & .25 \\
1.25 & 2.15 & .25 \\
1.20 & 2.00 & .25 \\
1.15 & 1.95 & .25
\end{tabular}

NOT PREPAID

2 lbs. 5 lbs. 10 lbs. $100 \mathrm{lbs}$

$\$ .35 \quad \$ .80 \quad \$ 1.40 \quad \$ 12.00$

$\begin{array}{llll}.30 & .70 & 1.20 & 9.50\end{array}$

$\begin{array}{llll}.30 & .70 & 1.15 & 9.50\end{array}$

$\begin{array}{llll}.35 & .70 & 1.20 & 10.00\end{array}$

$\begin{array}{llll}.45 & .95 & 1.70 & 15.00\end{array}$

$\begin{array}{llll}.45 & 1.00 & 1.80 & 16.00\end{array}$

$\begin{array}{llll}.40 & .95 & 1.65 & 14.50\end{array}$

$40 \quad 90 \quad 1.60 \quad 14.00$ 
Stowell's Evergreen The well known standard sweet corn universally grown and a favorite variety with both home towell long deep white grains, very tender and sugary, of exceptional flavor and quality. The ears grow to a large size, which remain green and in condition for cooking through a long season. Because of this quality its name "Evergreen" was derived. See Preceding Page for Prices.

\section{POP CORN}

The prices of both varieties of Pop Corns for planting are the same. Pkt. 10c; lb. 30c; 2 lbs. 50c; 5 lbs. 95c; 10 lbs, $\$ 1.60$, postpaid. Not prepaid, $1 \mathrm{~b} .20 \mathrm{c} ; 2 \mathrm{lbs} .35 \mathrm{c} ; 5 \mathrm{lbs} .70 \mathrm{c} ; 10 \mathrm{lbs} . \$ 1.25$.

White Rice The most popular of all varieties for commercial use. Pops pure white crisp and tender.

Queen's Golden A handsome large eared, smooth yellow varicty, but pops a perfectly pure white, crisp and tender. Pop Corn for popping. l'er lb. 15c; 2 lbs. 30c; 5 lbs. 75c; 10 lbs. \$1.20, postpaid. Not prepaid, lb. 10c; 2 lbs. 20c;

\section{CAULIFLOWER}

CULTURE-Cauliflower should be grown and cultivated in all respects like cabbage (see cultural directions for cabbage), except when the heads form. The loose outer leaves should be brought together and tied over the heads to keep out the light and make them bleach and whiten. Set in moist soil and keep well watered. One ounce of seed will produce about 2,000 plants.

Early Snowball The leading variety and unquestionably the best Larly Snowball early maturing cauliflower. The heads are large and uniform in shape, firm and of excellent quality and snowy whiteness. Pkt. 20c; $1 / 4$ oz. $65 \mathrm{c} ; 0 z ., \$ 2.00 ; 1 / 4$ lb. $\$ 7.00$, postpaid.

Autumn Giant The best late variety. The heads are very large, Auturm and compact and remain a long time fit for use. l'kt. $10 \mathrm{c} ; 02.40 \mathrm{c} ; 1 / 4$ lb. $\$ 1.25$, postpaid.

\section{EGG PLANT}

CULTURE_-Sow in February or March $1 / 2$ inch deep, in hotbeds or boxes inside. When the plants are 2 inches high transplant to pots or good rich soil, after all danger of frost is past and the warm weather becomes permanently settled and the ground is thoroughly warm, set out in 3 -foot row3, 2 feet apart in the row. The ground should be a good rich loam. Keep the plants free from insects by applying Slug Shot or Bug Death. One ounce of seed will produce about 1,000 plants. The seed of Egg Plant is quite delicate and is slow to germinate, requiring more heat than is necessary or desirable for other nlants.

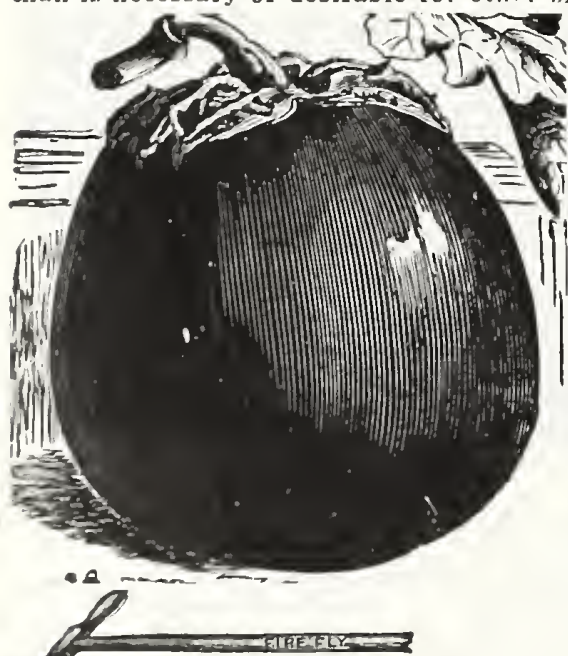

Black Beauty

This is the earliest and the best of all large-fruited egg plants. The large fruits are thick and of the most attractive form. The skin is a rich, lustrous, purplish-black and holds its color exceptionally well, and it is entirely free of spine or thorns. We consider this really the best Egg Plant in cultivation and therefore do not carry any other. Pkt. $10 \mathrm{c}$; oz. $40 \mathrm{c} ; 1 / 1 / \mathrm{lb}$. $\$ 1.35$, postpaid.

\section{LEEK}

American Flag This belongs to the Onion famcooking and for flavoring soups, stews, etc. Is said to be superior to Onions for this purpose. It has large, thick stems of a sweet flavor. Sow in the early spring in rich, light, moist soil in drills, covering the seed about $1 / 2$ inch. When the plants are 6 inches high transplant to rows 12 inches apart, placing plants 6 inches apart in the row. As the plants grow draw the earth up to them to whiten the necks. Sow 1 ounce of seed to 100 feet of row. Pkt. 5c;oz. 20c; $1 / 1$ lb. $60 \mathrm{c}$; lb. $\$ 2.00$, postpaid.

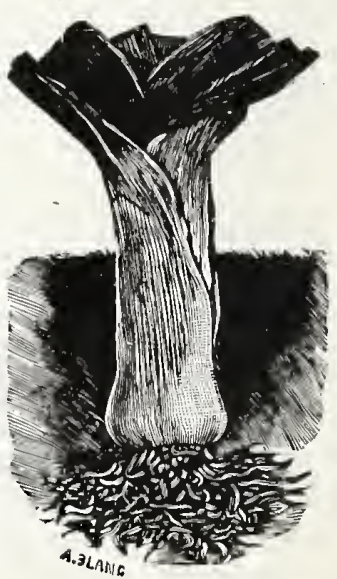

Leek

\section{THIS IS A FIRE FLY GARDEN PLOW}

An exceedingly useful tool to owners of small gardens. It will throw a furrow from 4 to 6 inches wide and 1 to 3 inches deep, and deeper by going twice. This little tool will enable a busy man to do in his spare minutes much of the work of a family garden. Chicken raisers find it very useful in plowing up scratching yards.

Other Planet Jr. Garden Tools are listed on page 51. 


\section{CUCUMBER 5 los. may be ordered at 100 per lib. less than lb. price.}

CULTURE-To have very early cucumbers plant in small paper pots. Keep them in a hotbed and when plants are large enough slip plants and dirt out of the pots and set in hills outside after danger of frost, or for later crop plant outside after the ground gets warm, from April to July, in rich, well-manured hills 4 feet apart. Plant 8 to 10 seeds 1 inch deep around the hills. Later thin to 2 or 3 plants to the hill. Hoe or cultivate only until the plants start to vine, then pull weeds by hand. Cucumbers should be gathered as fast as they are large enough, for if left to ripen on the vine they will then cease to bear. $1 \mathrm{oz}$. will plant about 50 hills; 2 lbs. to the acre. If troubled with insects use Slug Shot.

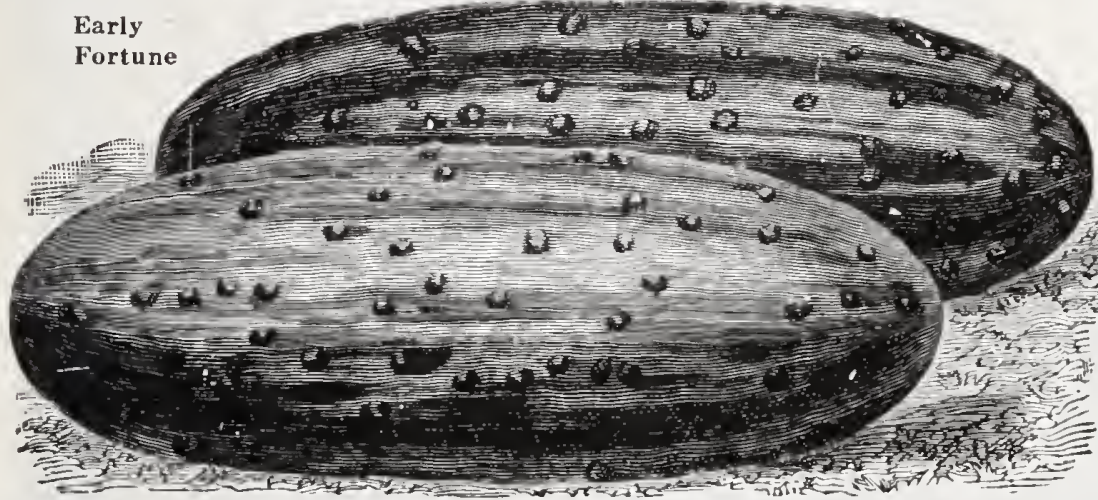

Early Fortune A very attractive early cucumber, especially recommended for early market use. It is of good length, slightly tapering, pure white firm flesh, unusually crisp and tender, with very few seeds. A favorite variety with many growers, because it holds its rich dark green color until fully ripe. The plants are vigorous and productive. Pkt. $5 \mathrm{c} ; 0 z .10 \mathrm{c} ; 1 / 1 \mathrm{lb} .30 \mathrm{c} ; \mathrm{lb} . \$ 1.00$, postpaid.

Klondyke A medium early white some dark green color and of excellent quality for slicing. When grown to maturity the fruit is about 8 inches long and uniform in size and shape. The dark green color is retained much longer and is affected less by the hot sun than any other sort which we know of. This quality makes it very popular as a shipping sort. Pkt. 5c; 0\%. 8c; 1/4 1b. 25c; 1b. 90c, postpaid.

Arlington Early White Spine A long, straight and well shaped variety of dark green color shading slightly cucumbers for both market and home use. Pkt. 5c; oz. 8c; 1/. 1b. 25c; 1b. 85c, postpaid.

Davis Perfect Similar to Early Fortune, a popular variety with market gardeners. Pkt. 5c; oz. 10c; 1/1 1b. 30c; lb.

Improved Long Green An old favorite and probably the most popular variety for general use. The fruits are extra flesh, crisp and tender, few seeds and especially fine for slicing. When 3 or 4 inches long they make especially fine pickles. This variety furnishes some fruits early, but matures the bulk of the crop rather late. A good variety for planting at all seasons from early spring to late summer. The vines are very healthy, vigorous and productive. Pkt. 10c; oz. 15c; 1/4 lb. $40 \mathrm{c} ; 1 \mathrm{~b} . \$ 1.25$, postpaid.

Green Prolific This variety is probably prized above all others for pickling purposes. The fruit is from 4 to 5 inches in length. A deep dark green color unusually crisp and brittle, moderately early. Very prolific and continues in bearing through a long season if kept gathered. A type of pickling cucumber which has every possible merit. Pkt. 5c; oz. 8c; 1/4 lb. 25c; lb. 90c, postpaid.

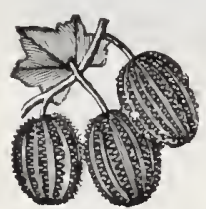

Gherkin or Burr Cucumber

Gherkin

This is the very small oval shaped prickly fruited sort, 1 or 2 inches in length, entirely distinct from all others and grown exclusively for pickles so popular with high class hotels and restaurants. Should always be picked when young and tender. Seeds germinate slowly. Pkt. 10c; oz. 20c; 1/4 1b. 50c; lb. $\$ 1.75$, postpaid.

\section{Mustard}

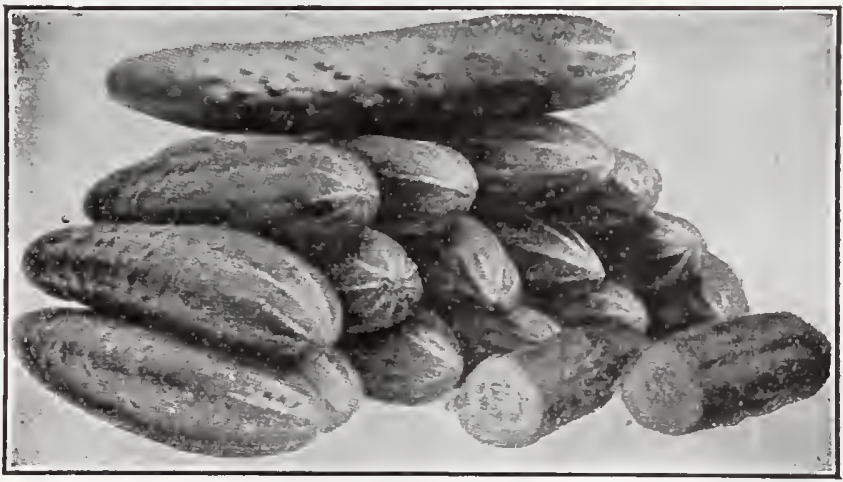

Arlington White Spine

CULTURE-For early use, sow from February to April. By sowing at intervals of every two weeks the salad may be had at its best through the entire spring. Can also be sown in September and October for late use. The leaves are large enough to use as a salad at from 4 to 6 weeks after sowing. May be sown in drills 6 to 8 inches apart. covering the seed $1 / 2$ inch. One ounce of seed will sow 75 feet of row in this way. Two pounds to the acre, or it can be sowed broadcast, when 5 or 6 pounds to the acre are required.

Southern Giant Curled The favorite in the South and the best of the finely curled varieties. The leaves are beautifully ruffed, curled and crimped around the edges. Is hardy, vigorous and ib. $60 \mathrm{c}$, postpaid.

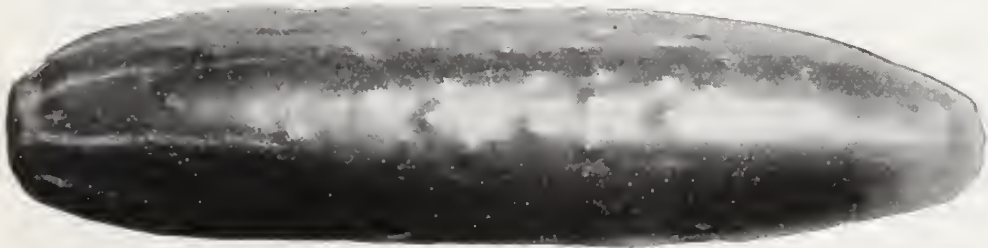

Fordhook Fancy Leaves are long, like, dark green, rather smooth and crinkled around the edges. Makes an extraordinary amount of foliage of attractive appearance. Oz. $10 \mathrm{c} ; 1 / 4$ lb. 25c; lb. 75c, postpaid. 


\section{CANTALOUPE or MUSKMELON}

$5 \mathrm{lbs}$. may be ordered at $10 \mathrm{c}$ per lb. less than $\mathrm{lb}$. price.

CULTURE-Plant late in April or May after danger of frost is past. The soil should be a light, rich loam, moderately dry, with perfect drainage, as cantaloupes cannot be grown to perfection under unfavorable conditions. Prepare the hills 4 to 6 feet apart, working thoroughly in each hill about 1/4 Ib. of D. \& B.'s Vine and Vegetable Fertilizer or a liberal supply of stable manure. Plant about 10 seeds around in the hill covering about 1 inch, and when about 2 inches high, pull out to 4 plants. Keep the ground well cultivated, mellow and free from weeds until the runners get a good start. At the last working about two ounces more of Fertilizer should be worked in around the Plants. When the vines are about 1 foot long or when they begin to blossom the runners should be pinched or clipped off, which will increase the yield of melons. One ounce of secd will plant about 50 hills; 2 lbs. for an acre. If troubled with inscets, apply Slug Shot.

\section{D.\&B,'s Golden Gem}

This is a delicious ly sweet cantaloupe of the well known Rocky Ford type. Has beautiful salmon colored flesh with a gold margin next to the seed cavity. The melons are medium size, uniform in shape, slightly oval and heavily netted. The flesh is fine grained and firm, which makes it a splendid shipping variety. The salmon flesh cantaloupes are becoming more popular every season and we consider our Golden Gem decidedly the best variety of this type. Pkt. $10 \mathrm{c}$; oz. $15 \mathrm{c} ; 1 / 4$ lb. $45 \mathrm{c}$; lb. $\$ 1.50$, postpaid.

\section{D.\&B,s' Netted Gem}

This is a decided improvement over the original Netted Gem, both in size and flavor. The melons grow to a larger size, are more uniform in size and

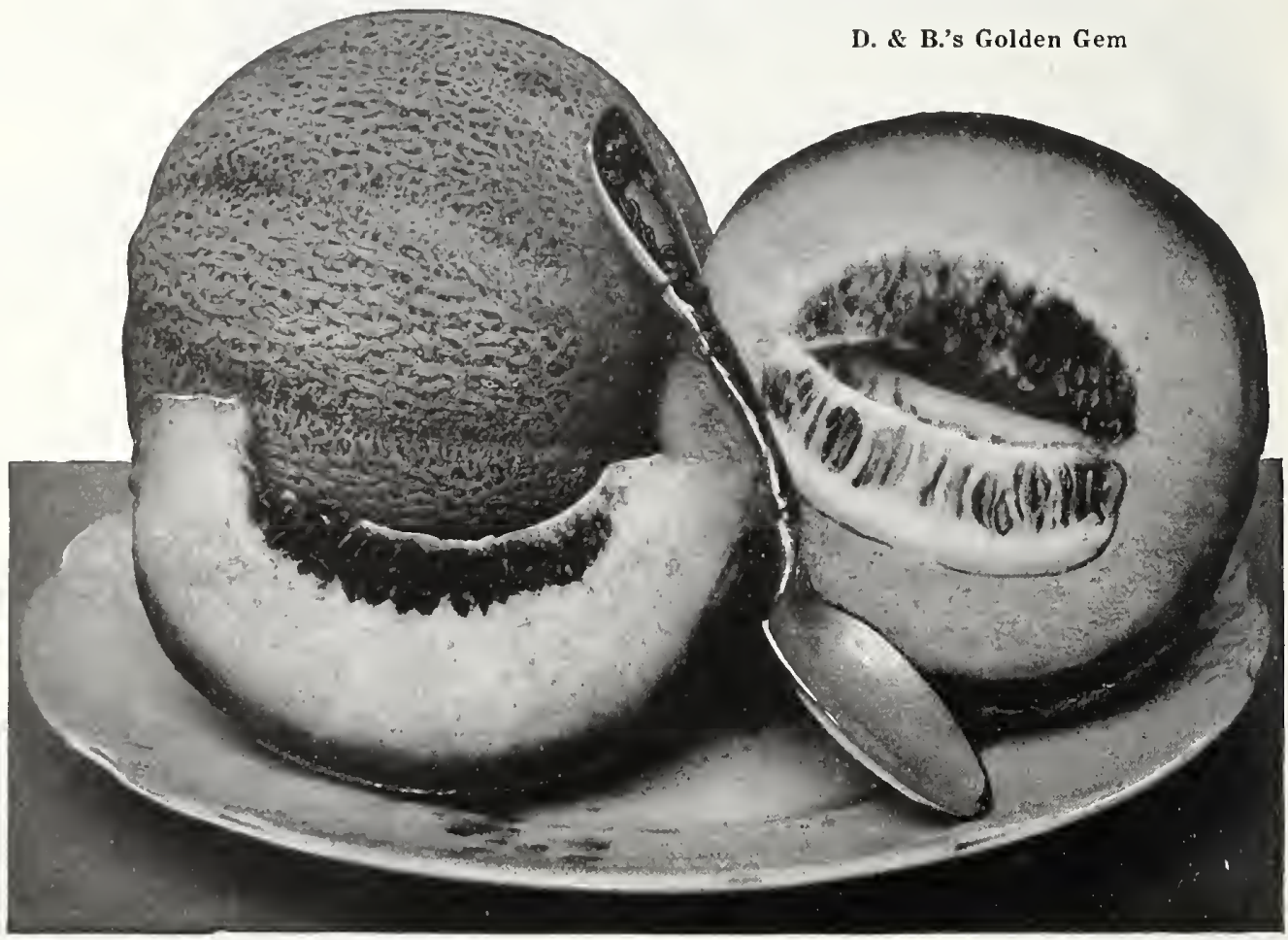
shape, while the flavor

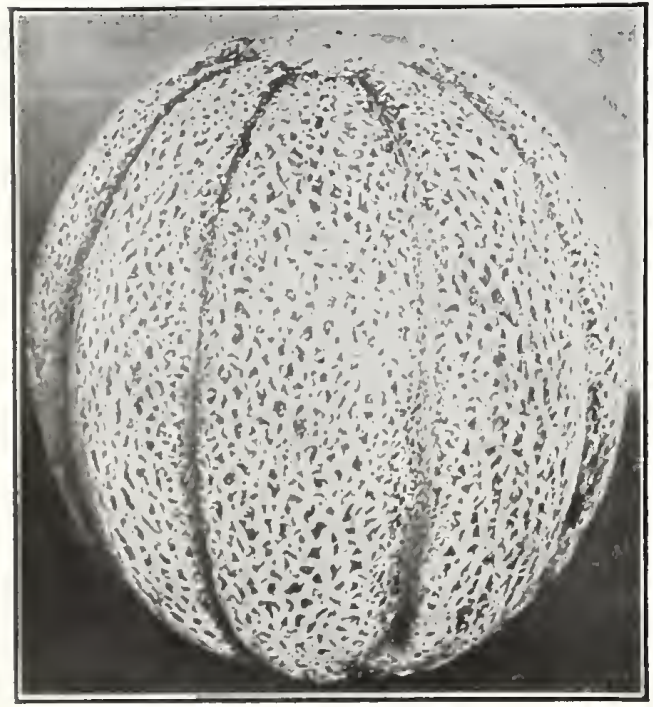

D. \& B.'s Netted Gem is delicious. The melons are slightly ribbed, oval shaped, thickly netted. Has a small seed cavity, thick green flesh deliciously sweet and juicy. Pkt. 5c; oz. 10c; 1/4 lb. 35c; lb. \$1.10, postpaid.

Knight About a week, or ten days earlier than the Rocky Ford and grows slightly larger. The melons are of oval shape and grow a uniform size, which is so highly desirable with market gardeners. They are handsome in appearance and thickly netted. Has thick green flesh edged with golden yellow, deliciously sweet and a pleasing aroma. A decided favorite with both market and home gardeners for early use. Pkt. 5c; oz. 10c; 1/4 lb. 35c; lb. $\$ 1.25$, postpaid.

Rocky Ford This well known cantaloupe is still a favorite with many early, rind is greenish in color and thickly netted. Small size nutmeg shape. The flesh is green, thick and of a delicious flavor. 0z. 10c; $1 / 1$ lb. 50c; lb. $\$ 1.50$, postpaid.

Hales Best A very early salmon fleshed melon of medium size, oval shaped, heavily netted with scarcely any ribs. The flesh is thick and deliciously sweet. Owing to its extreme earliness they are largely grown by market gardeners. They have been known to ripen in 68 days from planting. Pkt. 10c; oz. 15c; 1/4 lb. 40c; lb. $\$ 1.40$, postpaid. 


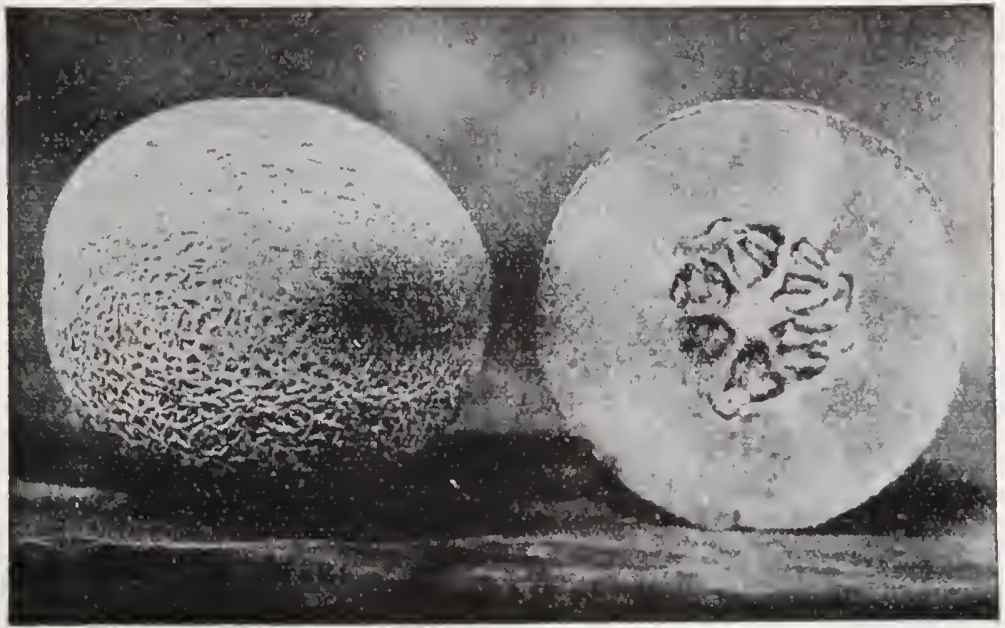

Perfecto

Perfecto These melons run from the avernearly round age standard to large size, are gray netting. In color the flesh is a beautiful salmon tint, which runs close to the rind, where it shades into a decided green. Has a very small seed cavity, thick flesh of excellent flavor. The vines are hardy and of vigorous growth. It is a prolific variety and carries a heavy crop of melons through the entire season. Pkt.10c; $0 z .15 \mathrm{c} ; 1 / 1 \mathrm{Ib} .50 \mathrm{c}$; lb. $\$ 1.50$, postpaid.

Tip Top A medium to large size melon, ored flesh, which is thick and firm. A good shipping and market variety. The flesh is deliciously sweet and juicy. The finest of the larger types of salmon-fleshed varieties. A most excellent melon. l'kt. 5c; oz. 10c; 1/ Ib. $35 \mathrm{c}$; lb. $\$ 1.25$, postpaid.

Honey Dew Melon This is a melon of is nevin, oval shape. growing is nearly white and is heavy, thick flesh of light green color, fine grain and of a distinctive delicious flavor, said to be a mingling of several flavors: Pineapple, banana and vanilla. Let them grow until thoroughly ripe, when the blossom end shows some softness, then keep several days after pulling before serving. It has a tough, thin rind, and the melons can be kept until cool weather. The vines are strong growers and productive. Pkt. 10c; oz. 15c; 1/1 lb. 40c; lb. \$1.35, postpaid.

Class Melon Sometimes called Vegetable Orange or Vine Peach. A of a lemon; used almost exclusively for pickles, making pies and preserves. Pickle factories purchase these in large quantities. Pkt. 10c; oz. 20c; 1/ lb. $60 \mathrm{c} ; \mathrm{lb}, \$ 1.75$, postpaid.

Banana This grows from 16 to 20 inches long, has smooth yellow skin Banana and is shaped like a banana. Has a most delicious odor and a good banana like flavor. Pkt. 5c;oz. 10c; 1/4 lb. 35c; lb. $\$ 1.25$, postpaid.

Mixed Cantaloupe As many of our customers prefer to grow cantaloupes of assorted varieties together, we offer these in mixture. Pkt. $5 \mathrm{c} ; 0 z .10 \mathrm{c} ; 1, \mathrm{ib} .40 \mathrm{c} ; \mathrm{lb} . \$ 1.25$, postpaid.

\section{Endive}

Green Curled Endive is a nice relish and makes a splendid salad for Green late fall and winter use, and nothing is prettier for garnishing. It has finely cut leaves, which give it a mossy appearance when blanched. It can be sown from April to August, $1 / 2$ inch deep in drills, and plants thinned to 8 inches apart. When nearly grown the outer leaves should be tied together over the heart to whiten it. Keep well watered in dry weather. One ounce of seed will sow 100 feet of row. Pkt. 10c; oz. $15 \mathrm{c} ; 1 / 4 \mathrm{lb} .35 \mathrm{c}$.

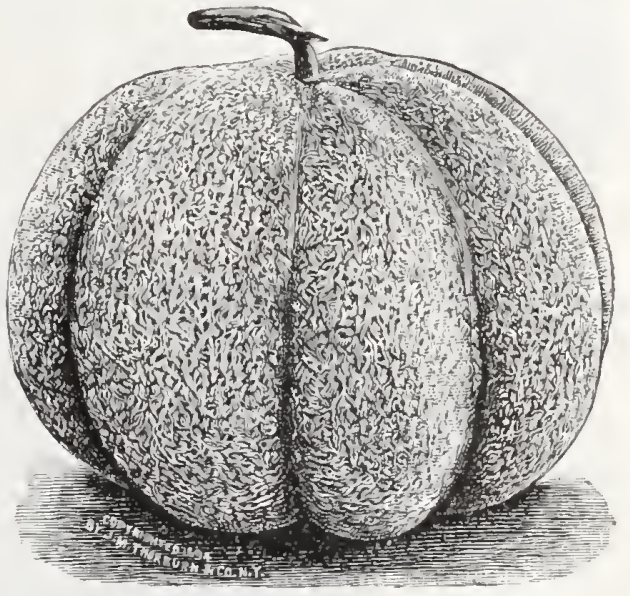

Tip Top

\section{Herbs}

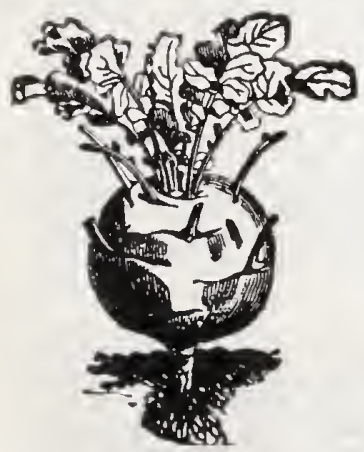

Kohl Rabi

As the seed of most Herbs are very small and delicate, they should not be sown until the ground becomes thoroughly warm. The soil should always be carefully prepared and kept entirely clean of weeds. Sow $1 / 2$ inch deep in drills early in the spring and when the plants are large enough, transplant to rows 16 to 18 inches apart.

Sage The most popular Garden Herb used for flavoring or seasoning. Pkt. 10c; oz. 25c;1/4 lb.

Dill Seeds have a strong pungent and aromatic fiavor, which are used as a condiment in pickles, Dill soups, stews, etc. Pkt. 10c;0z. 15c; 1/1 Ib. 35c; lb. $\$ 1.00$, postpaid.

Thyme Make delicious flavoring for sausage and meats. Pkt. 10c; oz. 50c.

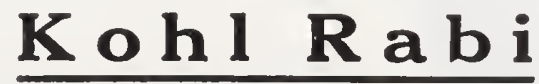

Early White Vienna The best variety, white and tender, combining somewhat the flavor: rown July. One ounce to 200 feet of drill. Pkt. 5c; oz. 15c;1/4 1b. 50c, postpaid. 


\section{WATER MELON}

5 lbs. may be ordered at $10 \mathrm{c}$ per lb: less than lb. price.

CULTURE-Plant from April to June after warm weather has become settled, as Melon Vines are rather delicate until they get a good start and do not thrive well if checked by cold and wet weather. Plant in well fertilized hills 8 feet apart, 8 or 10 seeds to the hill, covering about 1 inch. After they get a good start, thin to 3 or 4 plants. New ground or a broom straw field is an exccllent place in which to grow melons, as they thrive best in light, sandy soil. One ounce will plant about 25 or 30 hills; about 2 lbs. are required for an acre. As a protection against blight and insect pests, it is desirable to change the location of the melon patch each year. If troubled with insects, apply SIug Shot.

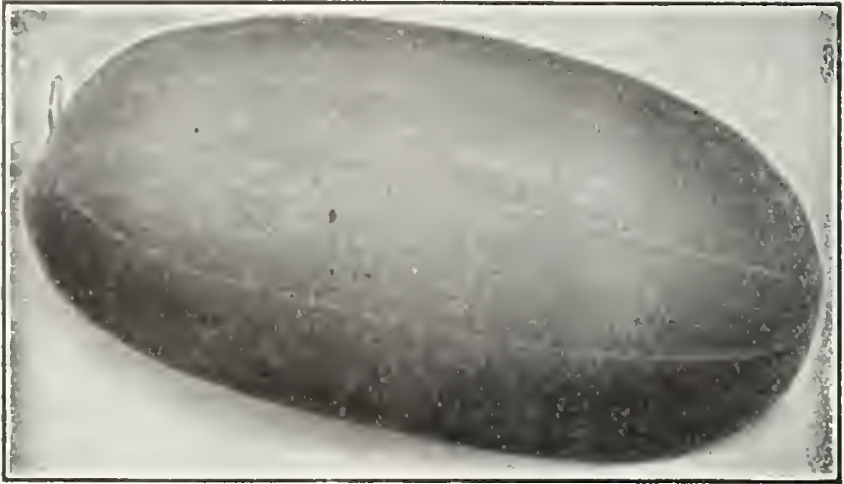

Kleckley Sweet
Our Melon Seeds are Southern grown and are saved from crops grown exclusively for seed purposes and the seeds are saved from the best selected melons only. No melons are sold or shipped from the crops from which our stocks are grown.

Kleckley Sweet Probably no other melon has ever use and nearby markets. This is a perfect melon for home purpose, but will not stand shipping. It is a long tapering melon, medium to large size, growing 18 to 24 inches long and 10 to 12 inches through. The skin is a rich dark green, very thin rind. Flesh a bright rich red, solid heart, exceedingly sweet, juicy and delicious, and ripens close to the rind. This variety is so crisp and tender that it will not stand shipping. A ripe melon when cut is so brittle that it cracks ahead of the knife like thin glass. A sign which all will recognize as a sure indication of a delicious melon so refreshing when served ice cold, Oz. 10c; 1/4 lb. 30c; lb. $90 \mathrm{c}$, postpaid.

Tom Watson This is decidedly the best and most popular melon grown for shipping. It is a long dark green melon. Has a thin, but tough elastic rind. Flesh is a rich bright red, firm and very sweet. Grows to a large size and is always uniform as to shape, size and colorings. One of its especially attractive characteristics is its permanent dark green gloss which makes it always look fresh as if it had just been pulled from the vine. Has taken the lead over all other melons for shipping to distant markets and generally brings the highest prices. Although a shipping melon many also prefer it for home use. Our stock of this melon is grown for us by an expert grower and the strain cannot be improved upon. Oz. 8c; 1/1 lb. 25c; lb. 75c, postpaid.

Wonder An improved strain of the Kleckley Sweet. While it has the same red flesh of delicious sweetness and all of Wonder the other splendid qualities, it grows to a larger size and can be shipped long distances. It is, indeed, a very fine melon and exceptionally handsome in appearance. Oz. 10c; 1/1 Ib. 30c; lb. 90c, postpaid.

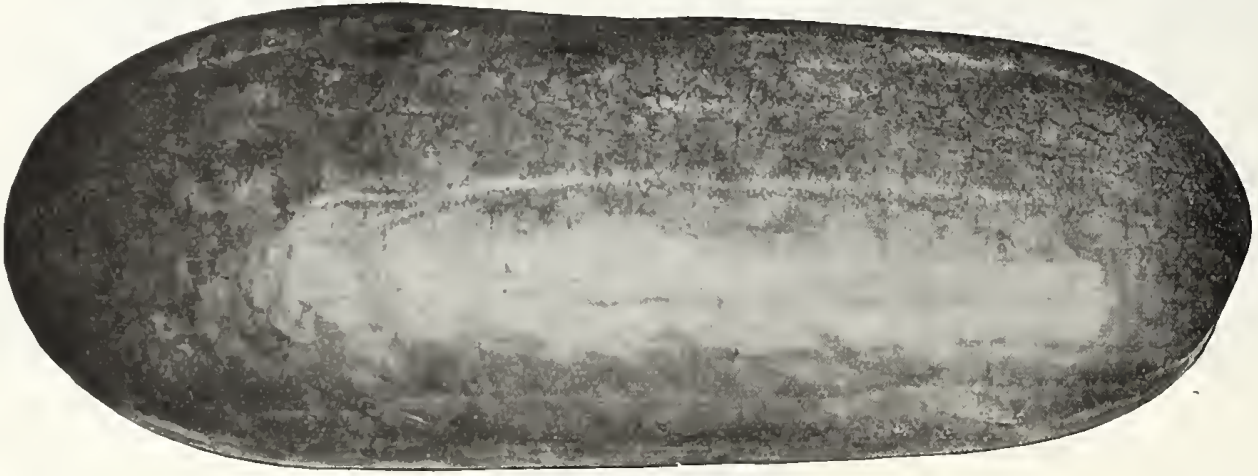

Tom Watson

Irish Gray A comparatively new melon that is becoming very popular as a shipping sort. It is a hardy, vigorous melon and one of the surest to make a crop, as the vines hold up and produce fine melons late into the summer after other kinds die out. It is a long melon with a distinctive greenish gray skin. On account of this it does not sunburn as easily as the green skin varieties. The flesh is a bright red, crisp, sweet and very firm, but free from stringiness. The rind is thin but tough and will keep in good condition a long time after being picked. Oz. 8c; $1 / \mathbf{A} \mathbf{l b}$. 25c; lb.
$75 \mathrm{c}$, postpaid.

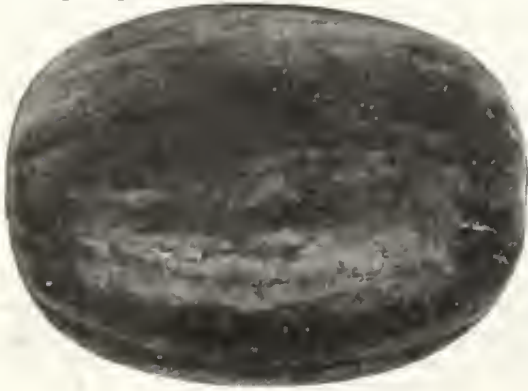

Stone Mountain.
Florida Favorite This is one of the oldest varieties and notwithstanding Forida Favorite the introduction of so many large fine melons, it still is one of the most popular varieties for home use and nearby market. It is oblong in shape, grows to a good size; the rind is thin, of a light green, with irregular mottled stripes of a dark green. The flesh is a bright deep red. There are few melons that equal this in tenderness and sweetness. Oz. 8c; 1/4 Ib. 25c; lb. 75c, postpaid,

Halbert Honey An early rapid growing melon of oblong shape, medium size the and very prolific, dark green, glossy skin, thin rind, crimson flesh, free from stringiness, and delicious. It bears a close resemblance to the Kleckley Sweet, except that it does not grow quite as large. It is a very pretty melon in shape and color, excellent for home use, but the rind is too thin and brittle to stand shipping. Oz. 8c; $1 / 4$ lb. 25c; lb. 85c, postpaid. 


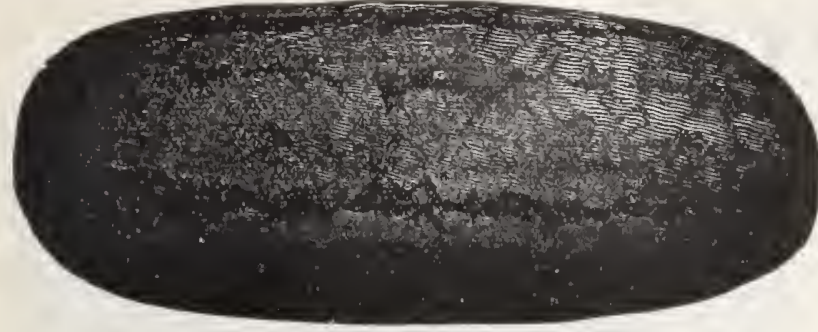

Florida Favorite
Stone Mountain Those who prefer a round or oval melon will be particularly pleased with this variety which has become so popular in many sections of the South. It is medium early, grows to a good size, has medium dark green rind, bright red flesh of delicious flavor. The vines are quite prolific and disease resistant. Recommended for home use or nearby market but does not ship well. Oz. 12c; 1/1 1b. 35c; 1b. \$1.15, postpaid.

Thurmond Gray Similar to the Irish Gray, except to it is a darker gray color. Grows tender, while the flavor is excellent. Does not sunburn. Ships splendidly. $0 \% .8 c ; 1,1 \mathrm{lb} .25 \mathrm{c} ; 1 \mathrm{~b}$. 80c, postpaid.

\section{K A L E}

CULTURE-The spring, plain or smooth kale may be sown in the spring from February to June or in the fall from September to December. This variety makes greens earlier from the time of sowing than the curled or winter varieties, and should be sown at intervals of 10 days in order to always have it tender. This is generally seeded broadcast about $10 \mathrm{lbs}$. to the acre. The Siberian and Scotch varieties should be sown from August 15th to October 15th, when they will make greens throughout the winter. The quality is improved rather than injured by frost, though both are frequently sown in the spring with satisfactory results. It is generally best to drill the curled varieties so that the plants may be cultivated. When drilled 1 ounce sows about 100 feet; $3 \mathrm{lbs}$. to the acre, or if seeded broadcast, about $5 \mathrm{lbs}$. to the acre are required.

\section{Spring Kale or Hanover Salad}

This is the well known, smooth leaf kale, sometimes called Hanover Salad, and is the best variety for sowing in the spring. It is tender and quick growing, being ready for cutting from 3 to 4 weeks from seeding, although it is usually sown in the spring, it also thrives well when seeded in the fall as it is very hardy, stands cold perfectly and can be cut any time during the winter. Pkt. 5c; 1/1 lb. 10c; lb. 30c; 2 lbs. 55c; 5 lbs. $\$ 1.20$, postpaid. Not prepaid, lb. 20c; 2 lbs. $40 \mathrm{c} ; 5$ lbs. $75 \mathrm{c}$.

Early Curled Siberian A very hardy'and vigorous growing variety of spreading habit. leaves are large, comparatively plain in the center, but are beautifully curled and frilled all around the edges. It retains its crisp, fresh appearance long after being cut. The favorite variety for fall sowing. Is slow to run to seed. Oz. 10c; 1/4 lb. 25c; lb. 75c, postpaid.

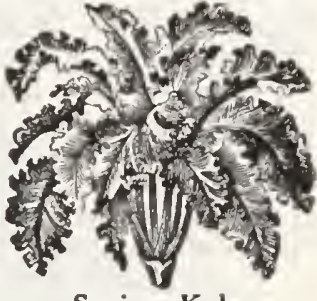

Spring Kale

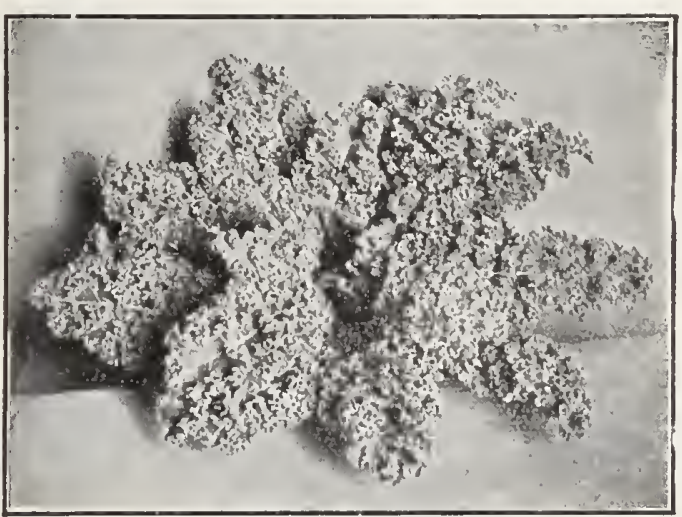

Early Curled Siberian

Curled Scotch A very hardy variety, widely spreading. The leaves Curled are a bright green and beautifully curled and crimped and are very firm and stiff, and when packed for shipping carry perfectly. Oz. 10c; 1/4 lb. 30c; lb. 90c, postpaid.

Long Season A distinct and hardy variety. The leaves are slightly curled, grows to a large size and it remains long er green without going to seed than any other variety. This kale can be cut for market long after all other kales and turnip salad have gone to seed. On account of its extreme hardiness and lasting qualities it has proven a most profitable variety for the market gardener. The seed of this variety will not be available until July, and is not recommended for spring sowing. Sow from July to October. Oz. 10c; 1/4 1b. 35c; lb. $\$ 1.00$, postpaid.

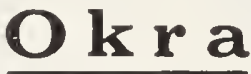

CULTURE-Sow in April or May after danger of frost is past and the ground becomes warm and as late as July if desired. Drill in rows 3 feet apart, covering the seed $1 \frac{1 / 2}{2}$ inches. Thin the plants of the tall growing varieties to 3 feet apart, and the dwarf varieties to 18 inches. Cultivate frequently and keep the earth well worked up to the stalk. One ounce will sow 50 feet of row.

Perkins Mammoth Podded Probably the most productive of all okras. The pods are Perkins Mammoth Podded prettily shaped, an intense green 8 or 9 inches long, tarting to shoot from 3 to 4 inches above the ground and the whole plant, which grows from 5 to 6 feet, is covered with them. Canners prefer it to all other kinds. Oz. 8c; 1/ 1b. 20c; 1b. $65 \mathrm{c}$, postpaid.

White Velvet Has round, smooth white pods of medium size and almost free from Oz. 8c;1/4 lb. 20c; lb. 65c, postpaid.

Dwarf Prolific The best dwarf variety begins to bear when very small, grows about 3 tender and of good quality. Oz. 8c; 1/4 lb. 20c; lb. 65c, postpaid.

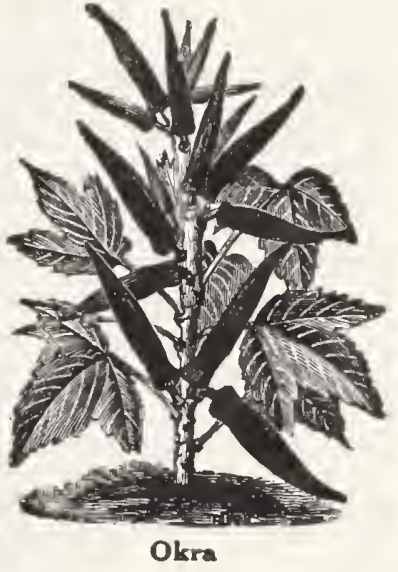




\section{E T T U C E}

CULTURE-To grow early lettuce the seed should be sown in January or February in seed boxes in the house or ander glass. When the plants are large enough, they should be hardened by exposure to cold weather before setting them outside. Transplant to rows 18 inches apart and from 8 to 12 inches apart in the row. For later use the seed may be sown in rows outside in the spring and the plants thinned to the proper distance. For a continuous supply, sow every 3 weeks. To raise the best lettuce, crisp and tender, quick growth is essential, which means thorough preparation in rich soil, frequent cultivations and plenty of moisture. For fall use, sow in July and August. During severe weather plants should be protected with a covering of straw or litter or they may be transplanted into cold frames to head during the winter. One ounce will produce about 1,500 plants.

Big Boston An excellent variety, which is probably more generally grown both for home use and market than any other lettuce. Has large broad, smooth leaves with a solid heart, beautifully blanched, crisp, tender and of perfect form. Heads up under cold weather conditions and keeps longer after being cut better than any other kind. The favorite variety with market gardeners for sowing in the open ground for fall use. Pkt. $10 \mathrm{c}$; 0z. $15 \mathrm{c} ; 1 / 4 \mathrm{lb}$. $40 \mathrm{c} ; 1 \mathrm{lb} . \$ 1.25$, postpaid.

Early White Cabbage A splendid lettuce both for Early White Cabbage forcing under glass and for sowing outside, either for summer or late fall use. It is a very hardy lettuce. Has large firm heads, blanched hearts; a really good lettuce for all purposes and next to Big Boston is the niost popular kind. Pkt. 10c; oz. 20c; 1/1 1b. 50c; lb. $\$ 1.75$, postpaid.

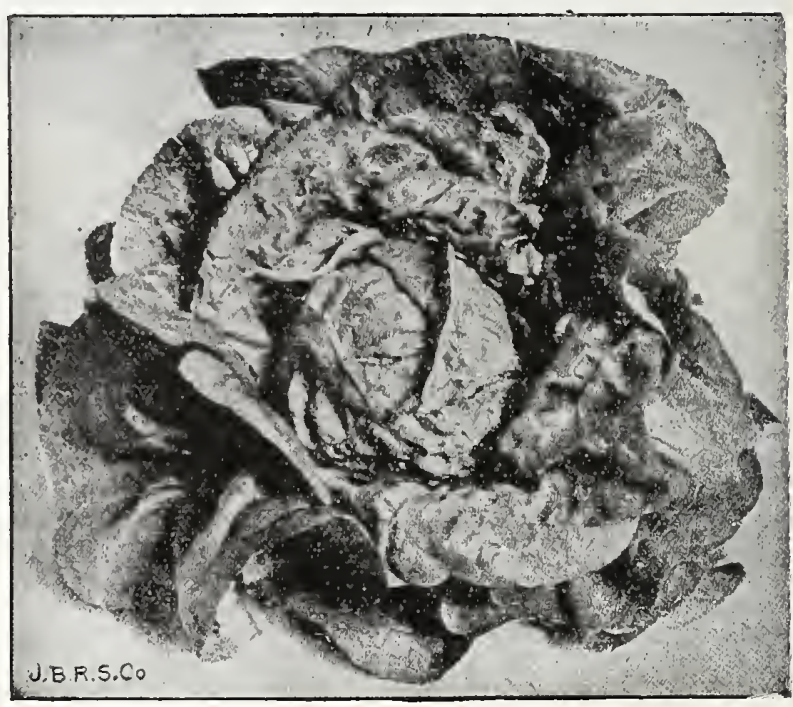

Big Boston

Iceberg A beautiful curled heading lettuce, exceedingly crisp and tender. Heads of conical shape and medium size, fold tightly and blanch to a beautiful white. The outer leaves are crinkled and light graen, growing closely up around the head. Especially fine for the home garden. Pkt. 10c; oz. 20c;

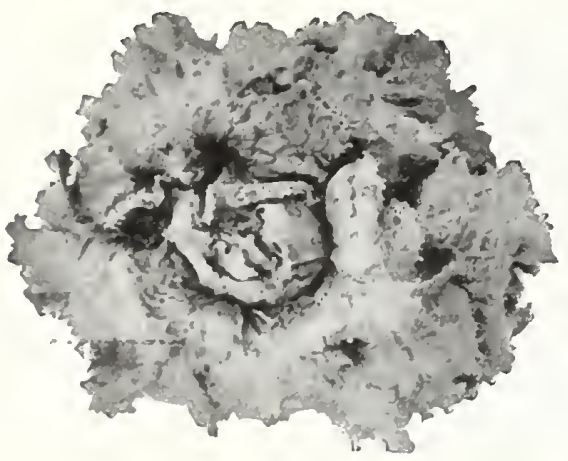

lceberg $1 / 1$ lb. $45 \mathrm{c}$; lb. $\$ 1.50$, postpaid.

Wayahead This is the earliest and hardiest lettuce for cold frames or open ground. Is of good quality and handsome appearance. It is earlier than the Big Boston, and the heads are more tightly folded. Preferred by some growers. Pkt. $10 \mathrm{c} ;$ oz. $15 \mathrm{c} ; 1 / 4$ lb. $45 \mathrm{c} ; \mathrm{lb} . \$ 1.50$, postpaid.

Early Curled Simpson An early lettuce with loose, but clustering crisp leaves, which are green in color, slightly frilled, in rows and cutting when the plants are young. Pkt. 5c; oz, 15c; 1/4 1b. 40c; lb. $\$ 1.25$, postpaid.

All Seasons The favorite summer lettuce; very large, but attractive appearance. Has firm solid heart of deep yellow, erisp and buttery. Is especially recommended for its heat-resisting qualities, preserving its freshness under trying conditions. Pkt. 10c; oz. 20c; 1// lb. 50c; lb. \$1.75, postpaid.

Chicken Lettuce This is not a heading variety for table use, but grows 3 to 5 feet high, and is somewhat like Kale in appearance. It produces an abundant growth of leaves, and after cutting it keeps on growing and makes an excellent green feed for ('hickens and Rabbits. Plit. 5c; oz. $15 \mathrm{c} ; 1 / 1$ 1b. 40c; lb. $\$ 1.25$, postpaid.

WE GUARANTEE safe arrival of all Seeds and other articles in this catalog at "Postpaid" prices. No other charges for insurance, bags or packing. "Postpaid" means we guarantee safe delivery to your Post Office Address.

D. \& B.'B GARDEN AND LAWN ENRICHER MAKES BETTER GARDENS AND MORE BEAUTIFUL LAWNS

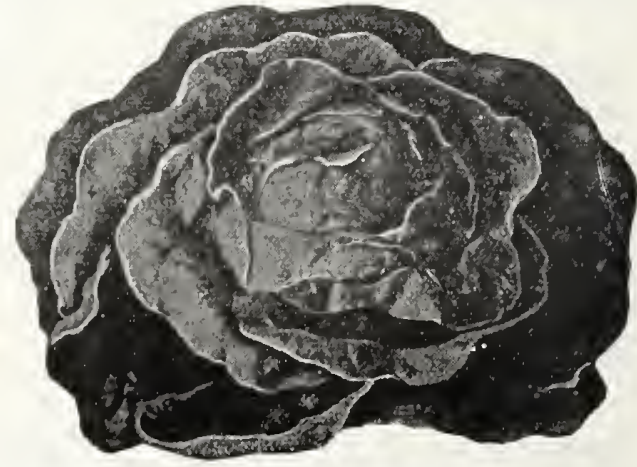

All Seasons 


\section{O N I O N}

CULTURE-Onions are grown from seeds and also from sets. To grow onions from seed, sow in February, March or April, rather thickly, $3 / 4$ inch deep in rows 18 inches apart, and later thin the plants to from 3 to 5 inches apart, and keep well cultivated. When grown this way 1 ounce of seed will sow 100 feet of row; 6 pounds to the acre. If sets for planting the following spring are desired, sow the seed in March or April in wide rows. 20 to 40 pounds to the acre. When the tops die in the summer remove and store the small sets, spreading them thinly in a dry place until ready for resetting, using the larger size for eating or pickling purposes. But the most satisfactory way for the small home gardener to grow early green onions is from sets. These may be put out in the spring, in March or April, or in the fall, in Septeinber and October. 3 inches apart in rows 1 foot or more apart. One pound of sets will plant about 75 feet of row. Onions require rich soil and a liberal supply of high grade fertilizer, or manure from the poultry house is very beneficial. Keep well cultivated and free from weeds.

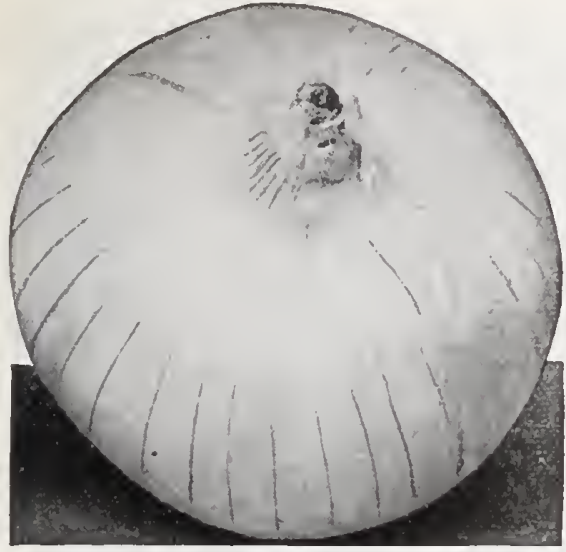

Early White Pearl This beautiful white onion is more largely grown by earliest of the white onions, being a beautiful, clean, waxy white, symmetrical in shape, rather flattened, flesh of a pure snowy whiteness. Very tender, mild and sweet. Truckers find it the most profitable to bunch and sell green with tops on. They do not keep very long and should not be held very long after maturing. The seed are sown in the spring. The sets put out in the fall which make large onions early the following spring long before any other kinds are ready. Our seed stock is grown especially for us in Italy by a grower of many years experience who has produced this superior strain. Pht. 10c; oz. 25c; 1/ lb. 70c; lb. \$2.50, postpaid. Prize Taker A very handsome onion of the largest size, measuring 12 inche or main crop. It is globe shaped. The skin is a rich yellow straw color, slightly tinged with brown. The flesh is creamy white, very mild, tender and of excellent flavor. Keeps well when thoroughly ripened, and a favorite kind for shipping for fall and early winter use. Pkt. 5c; 0z. 15c; 1/ lb. 50c; lb. \$1.85, postpaid.

\section{Early White Pearl}

Silver Skin A beautiful medium sized Silver Skin onion. Is nearly round and has clear white skin, mild flavor and sweet. Is a favorite with many for use when young, as a salad or bunching onion and for pickles. Is also fine for fall and early winter use. Largely used for growing sets. I'kt. 10c; oz. 20c; 1/4 lb. 60c; lb. \$2.00, postpaid.

\section{Yellow Globe Danvers}

This has long been a popular and tensively used for spring planting standard variety and the most exer. The skin is light coppery yellow, flesh is a creamy white, mild, crisp and of splendid flavor. Medium to large size, matures early, ripens evenly and keeps well. Universally recognized as the favorite onion for the main crop. Pkt. 5c; oz. 15c; 1/4 lb. 45c; lb. $\$ 1.50$, postpaid.

Large Red Wethersfield The most generally grown red valiety. The bulbs are large, somewhat flattened. The skin is deep purplish red. The flesh is light purplish white, rath $r$ strong, but of pleasant flavor. Is hard solid and one of the best keepers. The best variety for poor, dry soils. Pkt. 10c; oz. $15 ; 1 / 4$ lb. 40c; lb. $\$ 1.40$, postpaid.

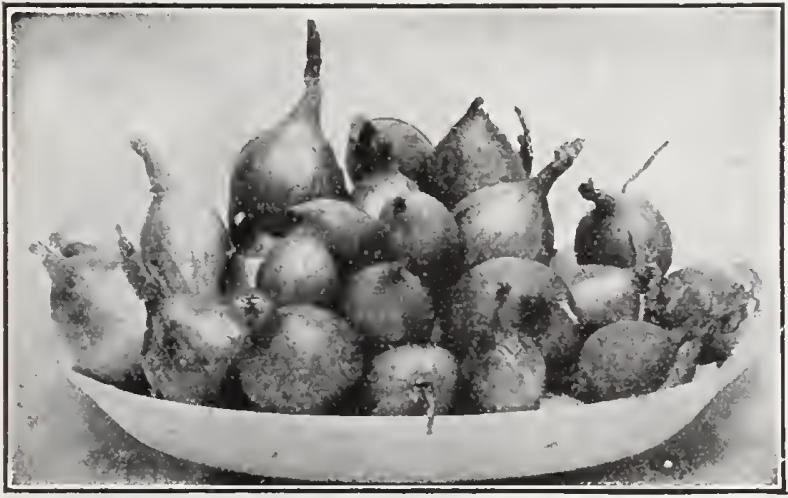

Onion Sets

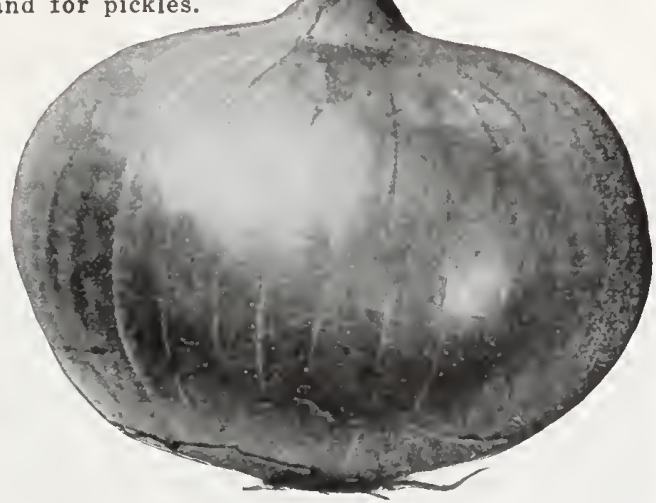

\section{Onion Sets}

MARKET FLUCTUATES

These Prices are Subject to Change.

1 lb. equals about 1 quart.

POSTPAID NOT POSTPAID

Per lb. 2 lbs. Per lb. 5 lbs. 10 lbs.

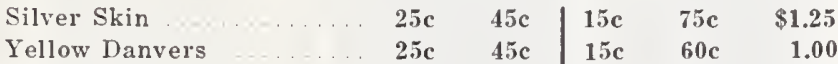

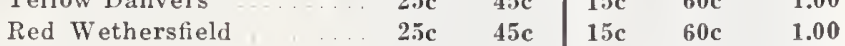

Japanese

\begin{tabular}{ll|ll}
$25 c$ & $45 c$ & $15 c$ & $60 c$
\end{tabular}

1.00

Ask for price of larger quantities.

White Pearl for Autumn planting, price quoted in season. 


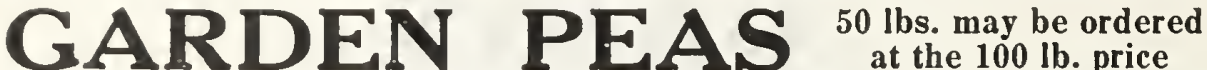

CULTURE-The extra early or smooth seeded varieties are very hardy and can be planted by January 15 th, or as early In the spring as the ground can be worked and until April 15th or later, while the wrinkled varieties are not as hardy and should not be planted until March 1st or later, as they are likely to rot if planted in cold, wet ground. The wrinkled varie. ties, however, are generally swceter and of better flavor. Peas thrive best when planted in light, loamy soil, which has been well fertilized the previous autumn, as fresh, rank manure applied when planting induces too heavy a growth of vine. Plant in rows about 3 feet apart and cover 2 to 3 inches. Keep well cultivated, drawing the earth up to the plants at each working to help in supporting the vines, until 6 inches high, then stake the tall growing varieties with brush or supports of some kind. Peas should be sown at intervals of every 2 weeks to give a continuous crop, and can be planted as late as August. They should be gathered as fast as they are ready for use, however, or they will stop bearing altogether. 2 pounds will sow about 100 feet of row: 100 lbs, to the acre.

PEIS BY WEIGHT

$1 \mathrm{lb}$. is about $1 \mathrm{pt}$.

$5 \mathrm{lbs}$, is about 2 16 ats.

$2 \mathrm{lbs}$. is about $1 \mathrm{qt}$. $10 \mathrm{lbs}$. is about 5 qts.

$15 \mathrm{lbs}$. is 1 peck.

$60 \mathrm{lbs}$. is 1 bushel.

\section{Smooth Seeded Varieties}

D. \& B.'s Extra Early This is our earliest and hardiest pea, and pea, it has no superior. It is very prolific, ripens uniformly, has handsome well filled pods and produces a large yield, but as is the case with all first early peas, they do not continue long in bearing, but yield 2 or 3 good heavy pickings. Owing to its extreme earliness it is a favorite kind with our market and home gardeners, who wish the earliest pea to ripen. Hcight $2 \%$ feet.

Alaska This is an old standard variety and a favorite kind with Alaska market gardeners for early planting, as it is early, hardy, ripens uniformly and retains its rich green color long after being picked. Because of these qualities and being green seeded, it is also the leading variety for canning purposes. Height $2 \frac{1 / 2}{2}$ feet.

D. \& B.'s Blue Bird An extremely early Pea, very hardy, of

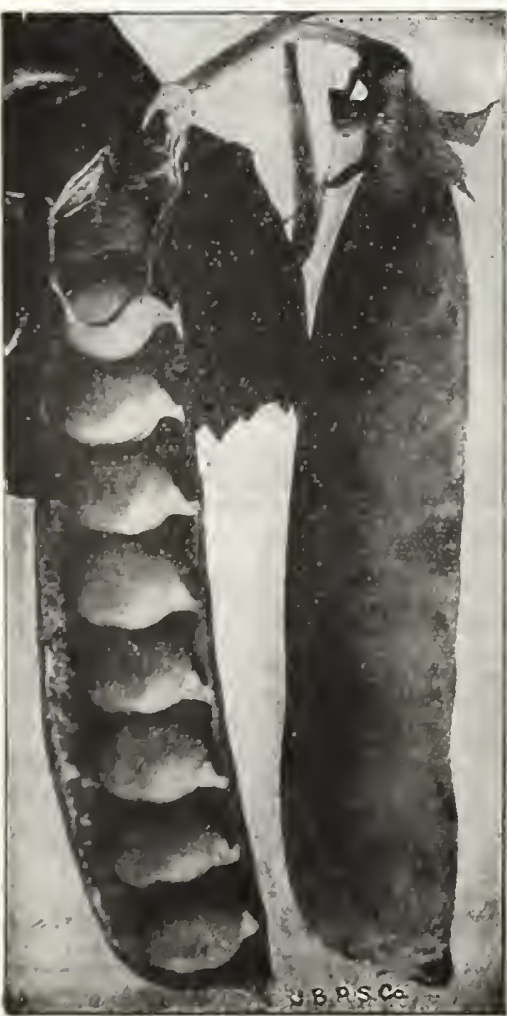
tive and is unusually productive for an extra early variety. The pods grow about 4 inches long, are deep green, well filled with 8 or 9 large Peas of a rich dark green. The seeds are Blue, semi-wrinkled, can be sown as soon as the ground can be worked, as they are very hardy and will not rot. Height $1 \frac{1 / 2}{2}$ to 2 feet.

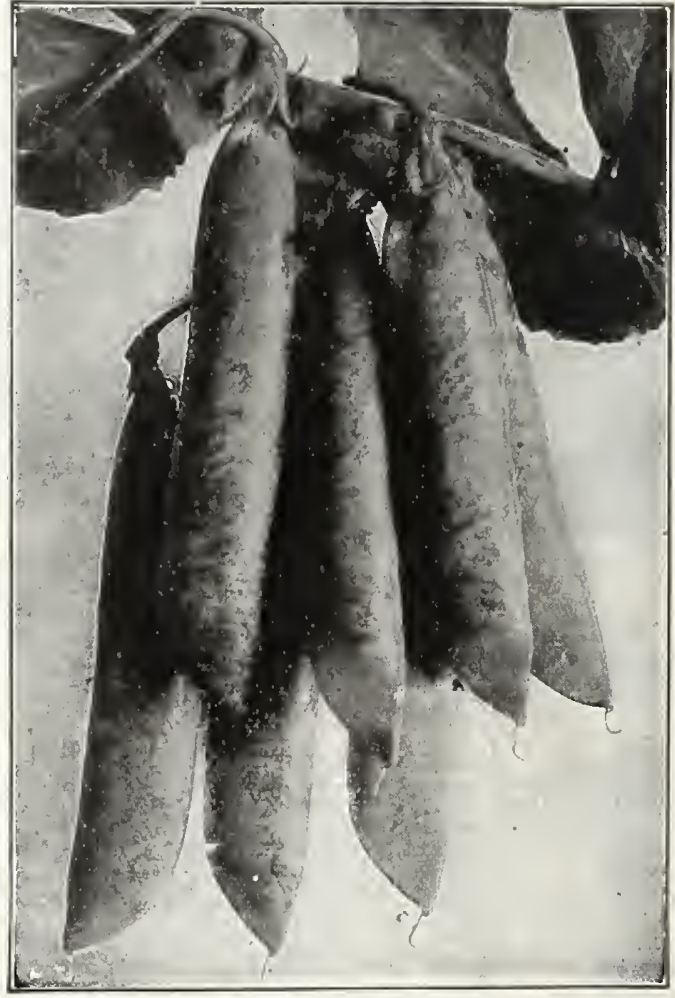

D. \& B.'s Extra Early

Large White Marrowfat A stout, hardy and vigorous growing variety, crop. Pods are light green, nearly round, about 3 inches long, full to the end, containing 4 or 5 Peas each. While not as sweet as the wrinkled varieties, it is one of the most productive of all Garden Peas. To have them at the best the Peas should be gathered when young. On poor soil they will probably outyield any other kind. Height 5 feet.

\section{PRICES}

D. \& B.'s Extra Early

Alaska

D. \& B.'s Blue Bird.

Large White Marrowat

Little Marvel

Thomas Laxton

Dark Green Telephone
BY MAIL POSTPAID

Pkt. 1/2 lb. 1b. 2 lb. 5lb. 10 lb.

10c 20 c 35c $60 \mathrm{c} \$ 1.20 \$ 2.05$

$\begin{array}{lllllll}10 & 20 & 35 & 55 & 1.15 & 1.95\end{array}$

$\begin{array}{lllllll}10 & 20 & 35 & 60 & 1.20 & 2.10\end{array}$

$\begin{array}{lllllll}10 & 20 & 35 & 55 & 1.05 & 1.70\end{array}$

$10 \quad 20$ 35 60

$\begin{array}{lllllll}10 & 20 & 35 & 60 & 1.20 & 2.05\end{array}$

$\begin{array}{llllll}10 & 20 & 35 & 60 & 1.20 & 2.05\end{array}$

\section{NOT PREPAID}

Lb. 2 lb. 5 lb. 10 lb. $100 \mathrm{lb}$.

$\begin{array}{lllllll}25 c & 45 c & \$ & .95 & \$ 1.70 & \$ 15.00\end{array}$

$\begin{array}{llrrr}25 & 45 & .90 & 1.60 & 14.00\end{array}$

$\begin{array}{lllll}25 & 45 & 1.00 & 1.90 & 16.00\end{array}$

$\begin{array}{rrrrr}25 & 40 & .80 & 1.40 & 12.00\end{array}$

$\begin{array}{lllll}25 & 45 & 1.05 & 1.90 & 17.00\end{array}$

$25 \quad 45$

$\begin{array}{lllll}25 & 45 & .95 & 1.70 & 15.00 \\ 25 & 45 & .95 & 1.70 & 15.00\end{array}$

Thomas Laxton

D. \& B.'s GARDEN AND LAWN ENRICHER

Makes better Gardens and more beautiful Lawns. A complete well-balanced organic fertilizer which gives splendid results when used on Gardens, Lawns, Shrubs, and Plants. For description and price see page 60. 


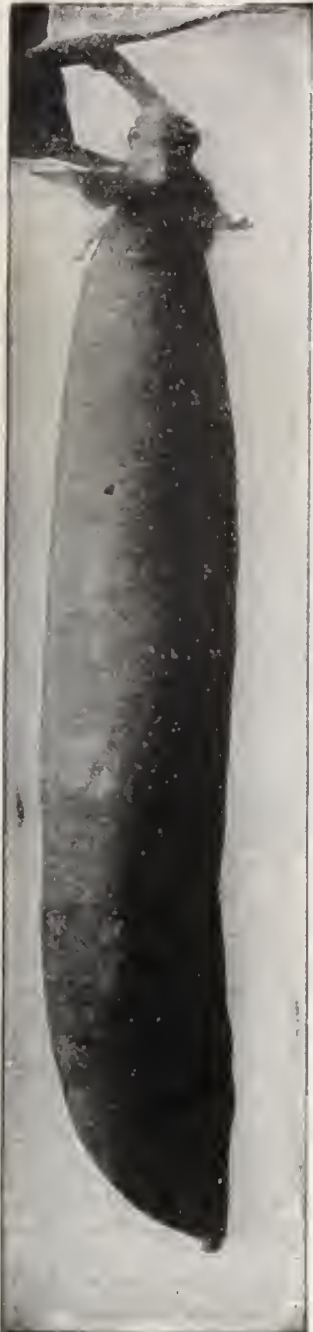

D. \& B.'s Dark Green Telephone

\section{Wrinkled Varieties}

Thomas Laxton Whilc a wrinlled pea, this is really an Extra Early variety and ripens fully as early as many of the smooth-seeded peas. It is very hardy, a strong and vigorous grower, producing pods in abundance and ripens uniformly. The pods are long, round and straight, of a rich dark green, well filled with 6 to 7 peas of large size, richly flavored and of unusual sweetness. We strongly recommend these as one of the best Early Peas for market gardeners, which arc growing in favor each year. Height 3 fect. See preceding page for prices.

Little Marvel A good second early wrinkled pea, has good size pods, and while attractive in shape and color, is not altogether as popular as Thonas Laxton, though a favorite with many for the family garden. Height 18 inches. See preceding page for prices.

\section{D. \& B.'s Dark Green Telephone We consider this one of the best of the large}

for late use. It is very productive, has long poir and filled with large peas, which are tender, sweet anl of excellent flavor. This has become the leading pea with both market and home gardeners for the late crop. Height 4 feet. See preceding page for prices.

\section{P U M P K I N}

CULTURE-Pumpkins are easy to raise and are very valuable for hogs, cattle and poultry as well as for table use, and should be more generally grown by farmers everywhere. When properly cared for and not allowed to bruise or sunburn, if placed in a cool, dry place, will keep indefinitely. Plant in May and June in rich hills 8 feet apart, covering the seed about 1 inch. Keep well cultivated, and when the plants are well up, thin to 3 of the strongest to each hill. Pumpkins also do well when grown in the corn, planting a few seeds in every fifth or sixth hill in every fourth or fifth row, letting the hill of pumpkin take the place of a hill of corn. Do not plant near melons, squashes or cucumbers, as they will hybridize, which will spoil the flavor of both. If troubled with bugs, use Slug Shot.

\begin{abstract}
Virginia Mammoth This is the
lar and probably the most satisfactory variety for growing in this section and further South. It grows to a very large size, is very prolific, of oblong shape, slightly ribbed, thick yellow flesh of splendid flavor, makes excellent pies and keeps indefinitely. Pkt. 10c; oz. 15c; 1 i lb. 50c; lb. $\$ 1.50$, postpaid.
\end{abstract}

King of the Mammoth This variety is recommended to pumpkins for their own gratification or for exhibition purposes, as it grows to an enormous size under the right conditions. Many pumpkins of this variety have been grown weighing more than a hundred pounds. Has firm yellow flesh, keeps well and a good

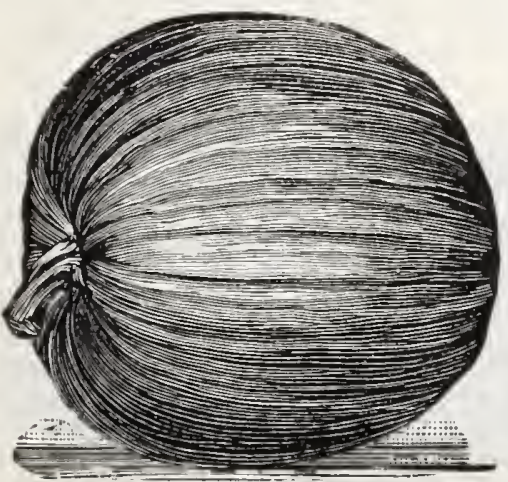

Corn Field variety for stock feeding. Oz. 15c; 1/1 lb. 40c; lb. $\$ 1.25$, postpaid.

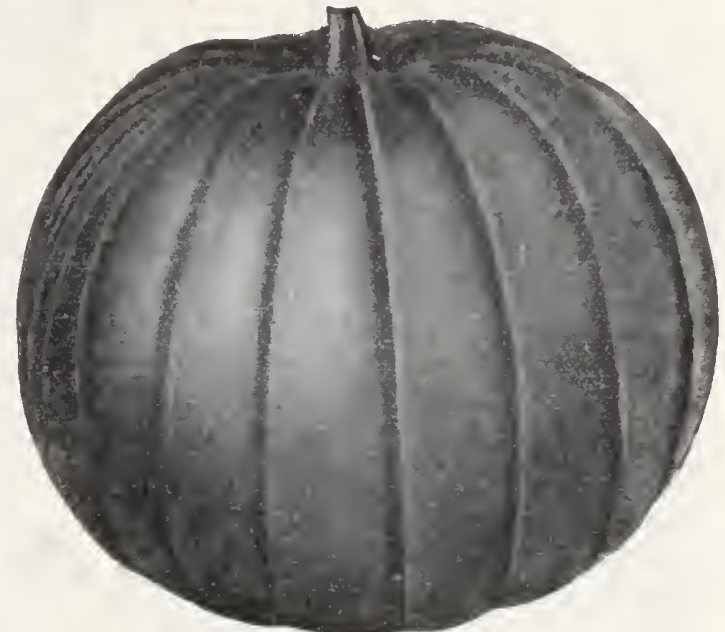

King of the Mammoth

Tennessee Sweet Potato An oblong variety of medium size, slightly Tibbed. Has a small seed cavity. The flesh is fine grained, very thick and dry, and makes deliciously flavored pies. Productive and keeps well. Oz. 10c; 1/ lb. 30c; lb. \$1.00, postpaid.

Small Sugar While this is not a large pumpkin, it is very prolific. The flesh - is fine grained of a rich yellowish red color, unusually sweet and keeps well. Probably the sweetest and one of the best varieties for making pies. Oz. 8c; 1/4 lb. 25c; lb. $85 \mathrm{c}$, postpaid.

Corn Field The well known standard pumpkin of medium size, but very productive on good land. Usually grown in corn fields, principally for stock. Oz. $8 \mathrm{c} ; 1 / 1 / 1 \mathrm{lb}, 20 \mathrm{c} ; \mathrm{lb} .60 \mathrm{c}$, postpaid. 

less than $\mathrm{lb}$. price

CULTURE-To have Radishes crisp and tender, they must be grown quickly, which requires rich, light soil, well prepared and plenty of moisture. For very early use may be sown in hot beds and given a plenty ventilation. For later, sow outside in drills at intervals of 10 days for succession. For fall and winter use, sow the winter varieties in August and September. Radishes being very hardy will endure moderately cold weather. They should be eaten when young and tender, as most varieties become pithy as soon as they are grown. One ounce will sow 50 foet of row, 8 to 10 lbs. to the acre, in drills.

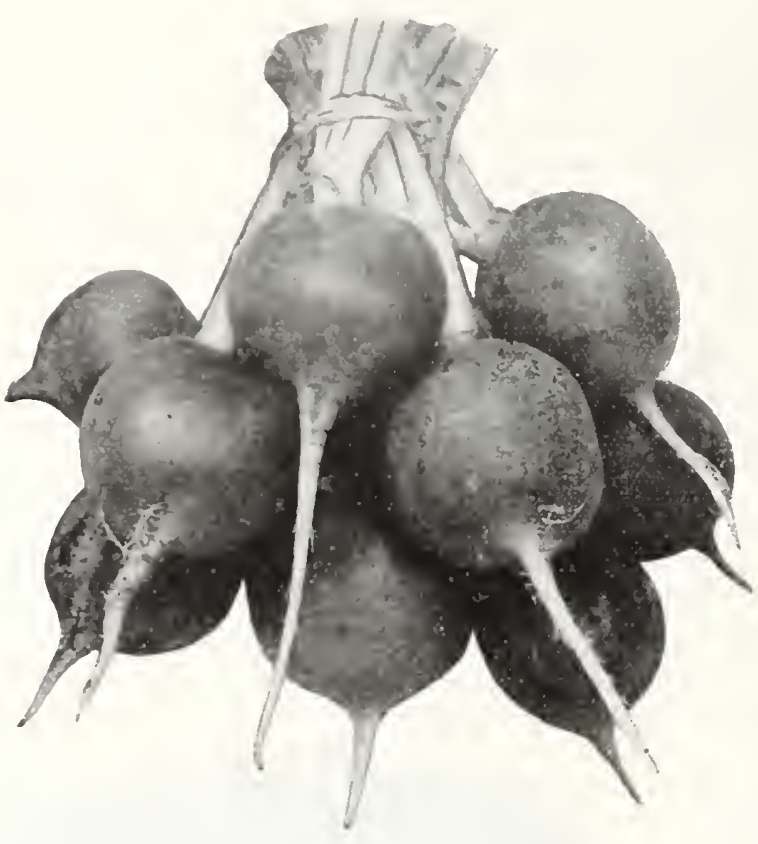

Early Scarlet Globe
Early Scarlet Globe This is probably the earliest forcing. A beautiful, transparent, round, bright red, has small tops with few short leaves. When pulled young is remarkably crisp and tender. Oz. 10c; 1/4 lb. 25c; lb. 80c, postpaid.

Early Red Turnip An early round, red Radish with quick growth and a favorite variety for the home garden for early outdoor planting. Oz. $10 \mathrm{c} ; 1 / 4$ lb. $25 \mathrm{c}$; lb. $80 \mathrm{c}$, postpaid.

Crimson Giant A second early Radish, which grows Crout twice the size of the Scarlet a brighter crimson color. It grows quickly, has pure white flesh and remains tender and of good flavor for sometime after development without getting pithy. Oz. 10c; $1 / 4$ lb. 25c; lb. 85 c, postpaid.

Sparkler White Tipped A very early Radish, very market, bright red with white tip. Makes a handsome, turnipshaped, clean root, fine for forcing, crisp, tender and mild. Oz. 8c; $1 / 4$ lb. 25c; lb. 75c, postpaid.

Long Bright Scarlet A quick growing variety, being after sowing. On account of its exceptional brittleness is sometimes called "glass radish." Is firm and crisp, has short tops and remains a long time in condition. A favorite long, bright radish for the family garden. To be sown outside for summer use. $\mathrm{Oz} .10 \mathrm{c}$; 1// lb. 25c; lb. 75c, postpaid.

D. \& B.'s GARDEN AND LAWN ENRICHER Makes Better GARDENS and More Beautiful LAWNS

Long White lcicle The earliest variety of this class being of more rapid growth than any long white radish. Is quite Long White cicle brittle with delicate tapering root well suggested by its name. A good variety for forcing and for growing outdoors. Oz. 8c; 1/t lb. 25c; lb. 75c, postpaid.

Rose China Winter Probably the best radish for winter use. The skin is deep rose color. The flesh pure white and - Grows to a rather large size, has smooth roots and keeps splendidly. Oz. 8c; 1/i lb. $25 \mathrm{c}$; 1b. 75c, postpaid.

Mixed Radishes As many of our customers prefer to sow radishes mixed, we offer these in mixture. Oz. $8 \mathbf{c}$; $1 / 4$ lb. Mixed Radishes 25 ; lb. 75c, postpaid.

\section{S A L S I F Y}

CULTURE-Sow from March to July in drills 18 inches apart, covering the seed one inch, and thin the plants to 4 or 6 inches and cultivate often. Salsify thrives best in a deep, rich. fine mellow loamy soil, previously enriched for some other crop, as applying fresh or coarse manure has tendency to induce ill haped, rough or sprangling side roots or forking, though an application of liquid manure in dry weather will be beneficial. The roots are perfectly hardy and may be left in open ground all winter, but should be taken up before growth starts in the spring. One ounce sows 50 feet of row $8 \mathrm{lbs}$. to the acre.

Mammoth Sandwich Island This is decidedly the orous grower and far superior to all other varieties. The long, white tapering roots are very large, smooth and well shaped and of a delicate oyster-like flavor. Pkt. 10c; oz. 20c: 1/4 lb. 60c; Ib. $\$ 2.00$, postpaid.

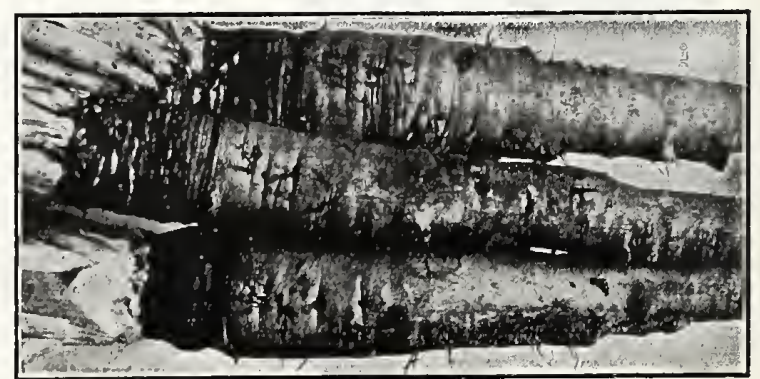

Saisify 


\section{S P I N A C H}

CULTURE-For early summer use, sow as early in the spring as the ground can be worked and for later use until April, after which time it runs to seed, except the New Zealand, which is a summer variety. For winter and spring use, sow from August to the middle of November. Spinach should be grown onlv in good soil, well fertilized, as it does not thrive on poor land. It is best to sow in drills about 18 inches apart, covering the seed about 1 inch and plants thinned to 4 or 6 inches. Spinach seed is rather delicate and it is sometimes difficult to get a good stand unless weather conditions are favorable. Two ounces of seed will sow 100 feet of row, $20 \mathrm{lbs}$. to the acre.

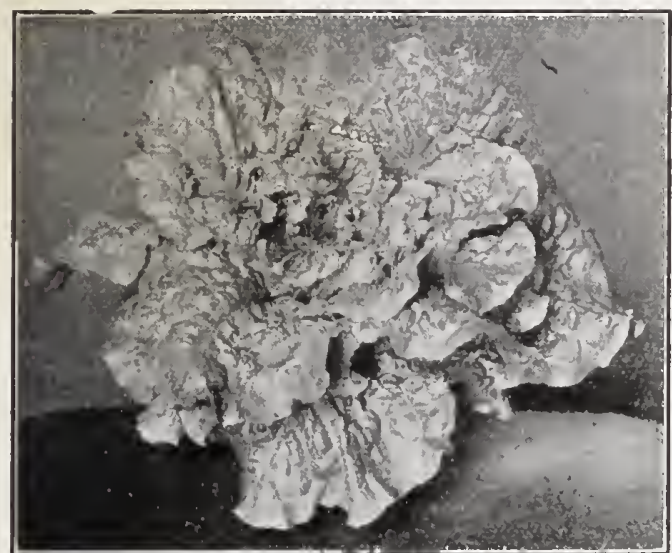

Norfolk Savoy Spinach
Norfolk Savoy or Bloomsdale We consider this variety so for spring and winter use, that we have discarded all other kinds. It is the standard spinach for the South. Is suitable for both spring and autumn sowing. Is early, very hardy, withstanding the winter, and grows rapidly, leaves are of the darkest green, curled to perfection and retains its crispness long after being cut, of delicate flavor, nutritious and digestible. Oz. 5c; $1 / 4$ lb. 15c; lb. 35c; 2 lbs. 60c; $51 \mathrm{bs} . \$ 1.20$ $10 \mathrm{lbs}$ \$2.10, postpaid. Not prepaid, 1b. $25 \mathrm{c} ; 5 \mathrm{lbs}$. at $22 \mathrm{c} ; 10 \mathrm{lbs}$. at $19 \mathrm{c}$; $25 \mathrm{lbs}$, at $18 \mathrm{c}: 100 \mathrm{lbs}$. $\$ 14.00$.

New Zealand This is strictly a summer spinach and should not is past It grows sown until April 15th or after danger of frost weather and produces an astonishing amount of foliage. The tender leaves may be cut every few days, when new leaves promptly take the place of those which aro cut and the new growth continues until frost. This variety should be in every Southern garden as an all-summer vegetable. It will not stand the winter as it is killed by frost. The seeds germinate better and more quickly if soaked in warm water overnight just before sowing. Plant 4 seeds in hills 2 feet apart. 0z. 10c; 1// lb. 25c; lb. 75c, postpaid.

\section{P E P P E R}

CULTURE-To make early peppers, sow the seed in boxes inside or under glass, in February or March, covering about $1 / 4$ inch and transplant outside after danger of frost is past, in rows 3 feet apart, setting the plants 18 inches apart in the row or for later use may be sowed outside and transplanted as above. Keep the earth worked up well against the stalks to support the plants. Pepper should be kept well cultivated and fertilized freely, which materially increases the yield. One ounce of seed will produce about 1,200 plants.

Royal King An excellent pepper propagated from the Ruby King, but Royal King a great improvement over that variety in that it makes a stronger and more vigorous plant. It produces abundantly very large smooth peppers, uniform in shape, bright ruby red, thick solid meat, mild, pleasant and very sweet. A splendid pepper for stuffing meats, salads, etc. Pkt. 10c;oz. 30c; 1/1 lb. 90c, postpaid.

Chinese Giant This is the largest pepper in cultivation. A brilliant thick, tender flesh, mild and sweet as an apple and makes an excellent salad. The plants are of stocky habit about 2 feet high, well branched and thickly set with fruit, which hang in clusters. Pkt. 10c;0z. 50c; 1/4 lb. $\$ 1.65$, postpaid.

Pimento This is the mildest flavored of all peppers and is entirely Pimento free of the pungent flavor, which so many consider undesirable. It is a beautifully heart-shaped pepper, bright scarlet color, perfectly smooth, uniform in size, thick flesh, bears abundantly and continues in bearing until frost. P'kt. 10c; oz. $25 \mathrm{c} ; 1 / 1$ lb. 80c, postpaid.

Long Red Cayenne This is the long, narrow finger shaped pepper. Has bright red pods and is very hot. The most popular variety for use in seasoning, pickling and drying for winter use. Pkt. 10c; oz. 30c; 1// lb. 90c, postpaid.
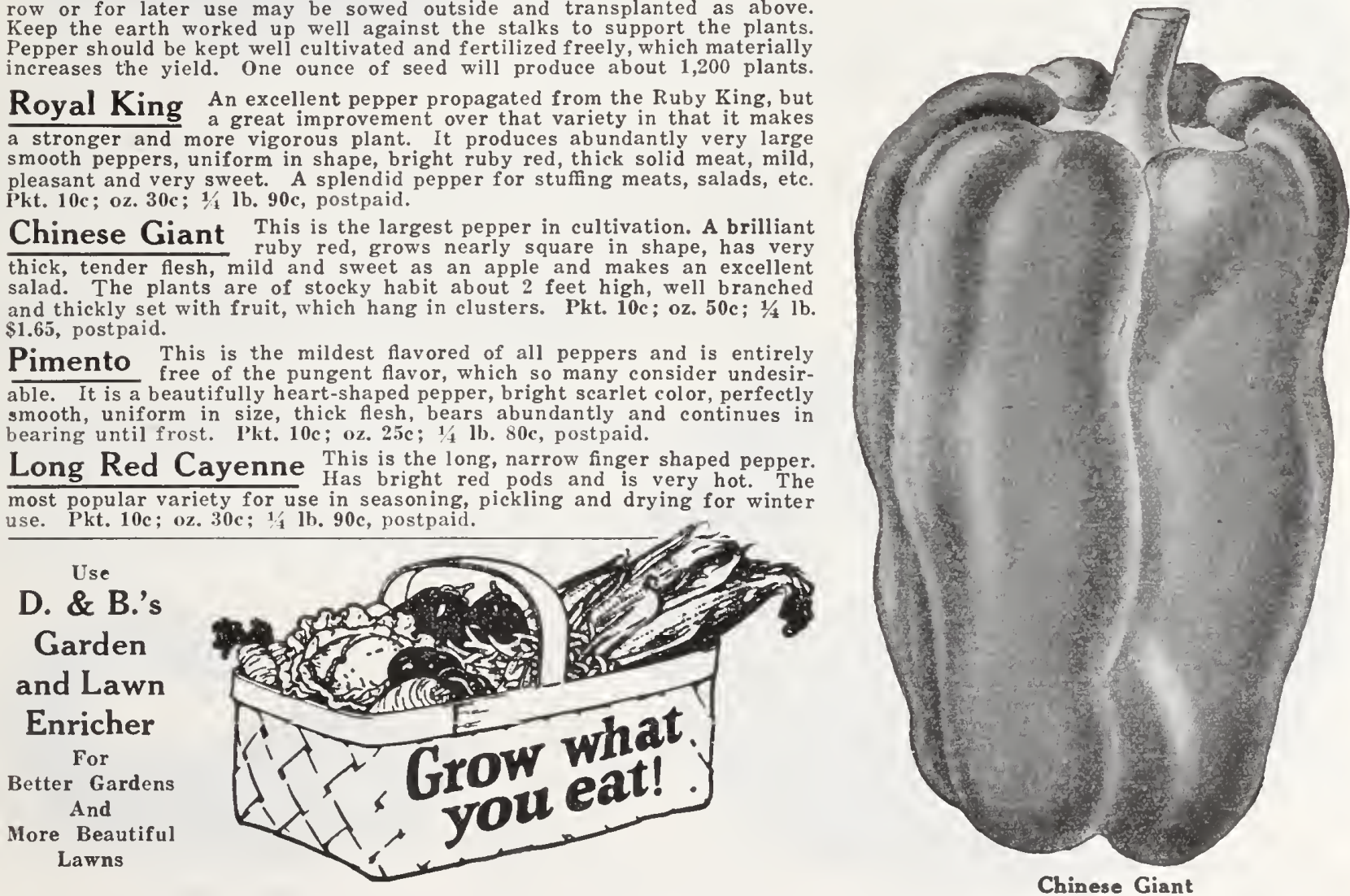


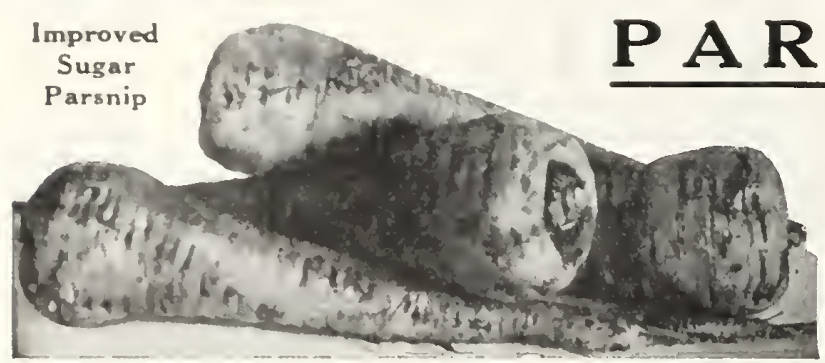

S N I P

CULTURE-Sow as early in the spring as weather conditions will permit or until the middle of June if desired, but as parsnip seed is very delicate and does not germinate well during hot weather, early sowing is recommended. Plant in rows 18 inches apart in rich sandy loam soil, deeply worked, covering the seed about $1 / 4$ inch, and thin the plants to 5 inches and cultivate frequently. Parsnips are excellent for stock as well as for the table, and are much improved in flavor by frost and may be left in the ground during the winter and dug as wanted. One ounce will sow about 100 feet of row; 5 lbs. to the acre.

Improved Sugar or Hollow Crown Has long, white, smooth roots. The flesh is tender, of good flavor and very sweet. Is uniform in shape and decidedly the best variety, either for table use or stock feeding. l'lit. 5c; 0z. sc; 1,1 lb. $25 \mathrm{c}$; lb. Sisc, postpaid.

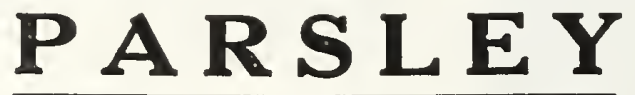

CULTURE-Sow in March or April in rich, mellow soil in rows 12 inches apart, covering the seed about $1 / 4$ inch, pressing down the soil after sowing. Parsley seed is very slow to germinate, often requiring a month or more. It is, therefore, best to soak the seed 24 to 48 hours before sowing, to hasten germination, covering the rows with boards or old bags to retain the moisture and prevent washing from heavy rains. With this precaution there is rarely any difficulty in securing a stand. Keep free from weeds by frcquent hoeing. One ounce will sow about 150 feet.

Champion Moss Curled We consider this the best and most satis: favoring soups, etc. The leaves are beautifully and very densely curled and crimped like luxuriant moss. Is also used as an ornamental plant for walks and borders. P't. 5c;0\%. 10c; 1/4 lb. 25c; 1b. 85c, postpaid.

\section{S Q U A S H}

CULTURE-After danger of frost is past, plant in rich, soit, loamy soil in well fertilized hills. Plant 8 to 10 seeds around in the hill, and when plants are well up and begin to leaf, thin to 3 of the strongest plants. The hills for the bush varieties should be about 5 feet apart and the running kinds about 8 to 10 feet. Keep well cultivated and free from weeds, until they get a good start. If troubled with bugs apply Slug Shot. One ounce will plant about 15 hills; 3 lbs. to the acre.

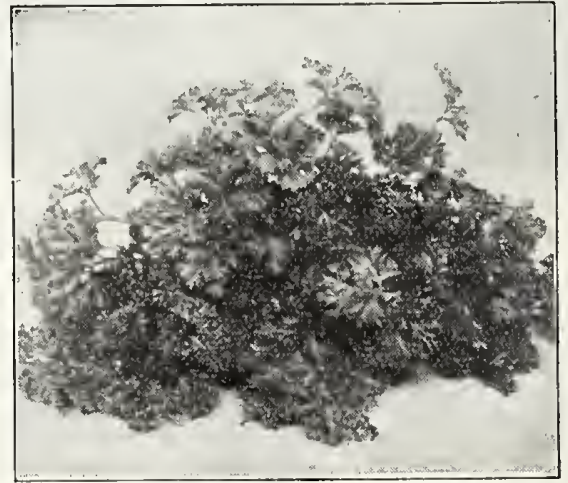

Champion Moss Curled

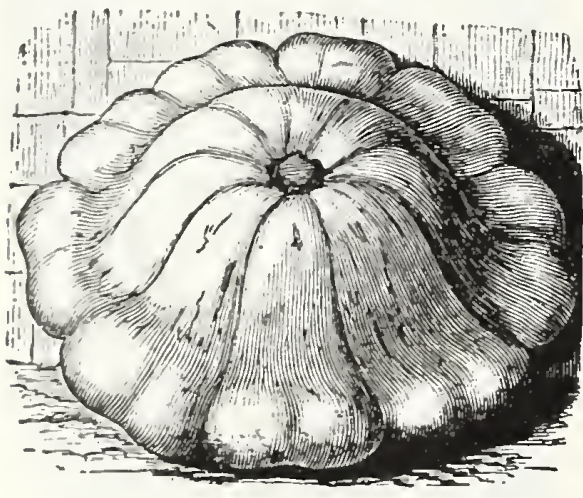

D. \& B.'s Early White Bush
D. \& B.'s Early White Bush The most popular variety for prolific, light cream color of delicate early home use. Is nice size, very truckers for nearby market and shipping. Oz. 8c; 1/4 lb. 25c; lb. 85c, postpaid.

Mammoth White Bush While similar in shape to the Early White Bush from which it was originally derived, it is of a considerably larger size and more uniform in shape, a beautiful waxy white color and about a week or 10 days later. Has tender flesh of good quality and yields abundantly. Oz. 10c; $1 / 41 b .30 c ; 1 b .90 c$, postpaid.

Giant Crookneck The best and richest Crookneck Summer Squash. yllow It is an early Bush Squash of bright golden continuously through the summer. Oz. 10c;1/4 lb. 40c; lb. $\$ 1.50$, postpaid.

Earliest Prolific This is the earliest variety, coming in a week or 10 days ahead of the Early White Bush. It is a favorite with market and home gardeners for the earliest crop. Pkt. 10c; oz. $15 \mathrm{c} ; 1 / 4$ lb. $40 \mathrm{c}$; lb. $\$ 1.50$, postpaid.
Hubbard Squash One of the most widely grown and probably the best large size and heavy. Has a greenish skin with very bright orange flesh. Fine graincd, sweet, very dry and richly flavored, a splendid keeper. Oz. 10c; $1 / 1$ lb. 30c; lib. $\$ 1.00$, postpaid.

Boston Marrow An old standard variety and one of the best for winter use, as it keeps so well. Of running habit, oval shape, thin yellow skin, orange colored flesh mottled with cream when ripe. Fine gratined, cooks rich and dry. $0 \% .10 \mathrm{c} ; 1 / 1 \mathrm{lb} .30 \mathrm{c} ; 1 \mathrm{~b} . \$ 1.00$, postpaid.

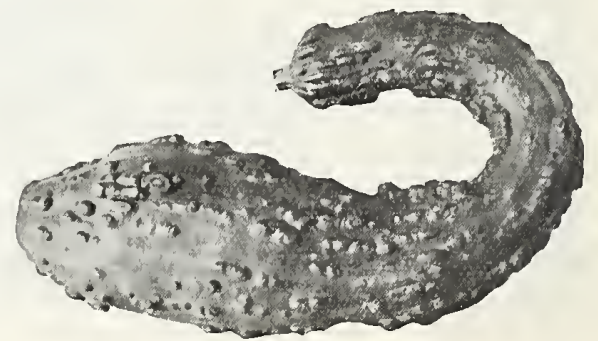

Giant Crookneck 


\section{T O M AT O}

CULTURE-To have plants ready for setting as soon as danger of frost is past, sow the seed inside in boxes or under glass about 6 weeks before the time desired to set them outside. After the weather turns warm, transplant and set in raised hills about 3 or 4 feet each way. Fertilize well with D \& B's Vine and Vegetable Grower or some high grade fertilizer and give frequent cultivations as long as possible. To make very early tomatoes, grow the plants in small pots and transplant to larger pots as the plants grow, until the weather is warm enough to set outside. It is best to furnish a strong support for the vines, so the fruit will be held well up off the ground, as tomatoes succeed so much better when they are supported by frames or trained on a trellis, we recommend that these always be used in the family gardens as a great deal of room can be saved and rotting almost entirely prevented. Spraying the vines with Bordeau will prevent blight. One ounce of seed will produce about 1,500 plants; 4 ounces will produce enough plants to set an acre.

Break O'Day This variety was introduced by Dr. Pritchard of the U. S. Department of Agriculture it being a cross with all of the good qualities of the blight resistant Marglobe, which is probably the best all round tomato grown. Break O'Day is a rich red Tomato of medium size and will, no doubt, become the most popular Tomato for early use. The supply of seed this season is small and we can offer it only in limited quantities. Plat. 10c: oz. 45c; 14 Ib. \$1.50, postpaid.

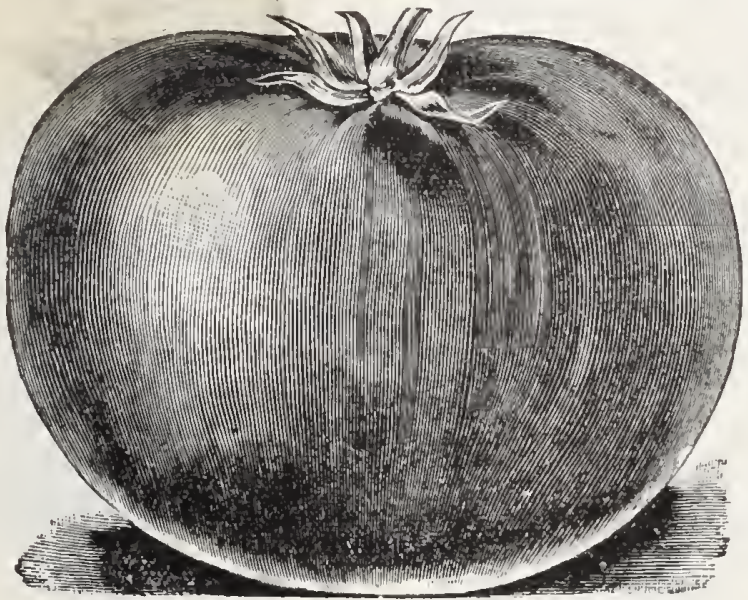

Bonny Best

June Pink One of the earliest varieties, of medium size, prolific and a good variety for the first early crop for the home garden. Is also a profitable sort for market gardeners, as it does not easily crack or bruise in shipping, but is not as good for the main crop as some other later maturing varieties. I'kt. 10c; oz. 35c; 1; lb. \$1.15; lb. \$4.25, postraid.

Bonny Best A first early Tomato, of good size, a beauFuit tiful red, nearly round and very prolific. tects it from the sun. A good and popular market variety. l'kt. 10c; oz. 25c; 1/ lb. 85c; lb. $\$ 3.00$, postpaid.

John Baer An early, bright red tomato of exceptional merit. The fruit is smooth solid, nearly ance. While a few days later than the June Pink, it produces a heavier crop and the fruits are larger and more uniform in size. We consider this the earliest large tomato. It has proven a most profitable kind for the market gardener. Pkt. 10c; oz. 25c; / lb. $80 \mathrm{c} ; 1 \mathrm{lb}$. \$3.00, postpaid.

Marglobe Rust Resistant-This variety was propagated by Dareau of Plant Industry of the U. S. Destrain of Tomato yet introduced. In addition to its Rust Resistant qualities it is a splendid Tomato for all purposcs. It is a second early kind, Globe shaped, rich red flesh, medium to large size, smooth skin and meaty, is non-acid, and almost

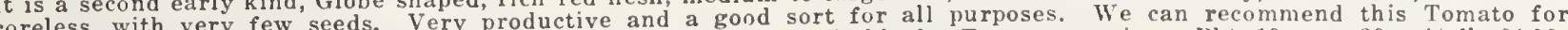
ither market, home use, or canning, and for any soil or climate suitable for Tomato growing. Pkt. 10c; 0z. 30c; 1/4 lb. \$1.00; lb. \$3.50, postpaid.

Stone For years this has been a very popular tomato as a main crop, for home use, market and canning and deservedly , ping variety, is unusually productive and withstands blight and rot. Pkt. 5c; oz, 20c; 1/4 1b. 70c; 1b. \$2.25, postpaid. Creater Baltimore ${ }_{\text {Is largely used for canning and is considered by many canners far superior to other varieties }}$

Brimmer This tomato is similar to the well known Brimmer Ponderosa, but a decided improvement over it. The fruit grows to a larger size, while the quality is splendid and is said to be superior to any other kind. It is practically all meat, has very few seeds and without any core. Of mild, delicate flavor and comparatively free from acidity found in so many other kinds. A splendid tomato for the family, but most too large for a profitable market sort. Has strong, healthy vines and bears abundantly until frost. Pkt. 15c; oz. $95 \mathrm{c} ; 1$; lb. $\$ 3.45$, postpaid. Ponderosa A handsome bright red tomato. Very largest tomatoes, the fruit often weighing over a pound, for this reason many prefer it for slicing. A general favorite for the family garden. The vines are vigorous and healthy and bear abundantly. Pkt. 10c;0z. 50c; 1/ lb. $\$ 1.65$; lb. $\$ 6.00$, postpaid.

Norton Wilt Resisting in shape, size and color to the well known Stone, but resists blight better than any other tomato. It is hardy, finely flavored and bears continuously until frost. Pkt. 10c; oz. 30c; 1/, lb. \$1.00; 1b. $\$ 3.50$, postpaid.

Yellow Pear Has small pear shaped fruit used preserves, while their size, shape, color and flavor make them desirable for use in salads. The vines are enormously productive. Pkt. $10 \mathrm{c} ; 0 \mathrm{z} .45 \mathrm{c} ; 1 / \mathrm{lb}$ lb $\$ 1.45$, postpaid.

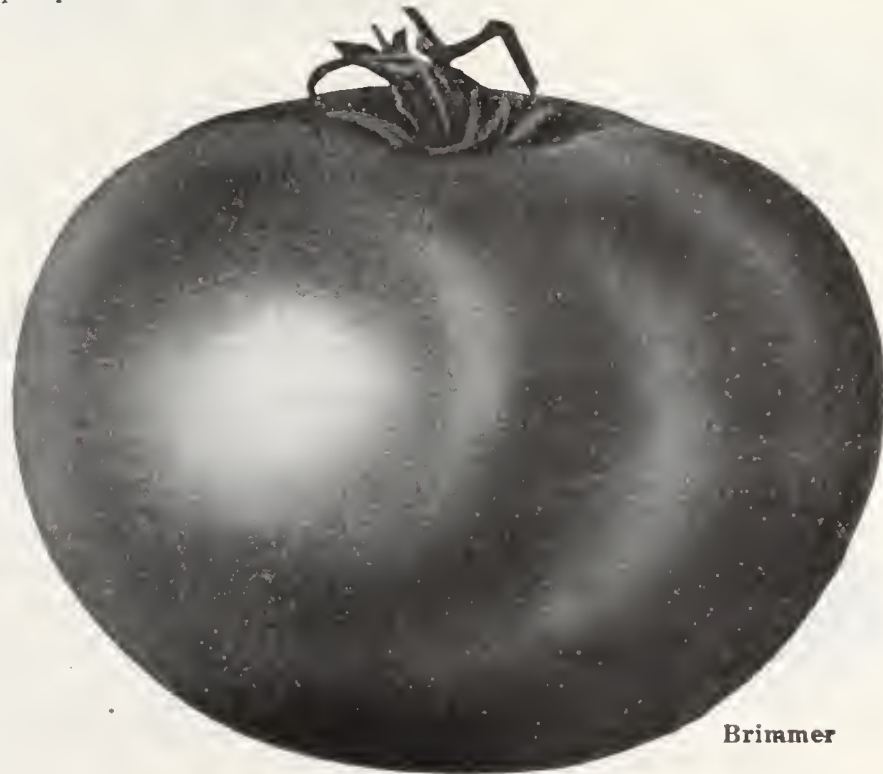




\section{T U R N I P}

CULTURE-The successful cultivation of turnips and Ruta Bagas requires that the land be thoroughly prepared, enriched and put in the best condition, covering the seed about $1 / 2$ inch. For regular crop for fall and winter use, sow from July to October. If drilled one ounce sows about 100 feet of row, $1^{1 / 2}$ lbs, to the acre. Rows should be 2 feet apart and plants thinned to 6 or 8 inches. When seeded broadcast $1 \frac{1 / 2}{2}$ to 2 pounds to the acre are required The salad varieties can be sown during August and September broadcast from 3 to 4 pounds to the acre.

Ruta Bagas should be sown from June to September. These thrive best if seeded in drills and cultivated, when about $1 \%$ pounds are required to sow an acre. Sow in rows about 2 feet apart and thin the plants from 6 to 8 inches. Ruta Bagas are also frequently seeded broadcast, when about 2 pounds to the acre are required.

\section{White Flesh Varieties}

Improved Red Top White Globe This is probably the handsomest and cerIt is a verv large variety. Many customers have produced turnips from our strain of this seed, weighing 8 lbs, and over. It is globe shaped with pure white flesh. The skin is purple above the ground and white beneath, making it most attractive in appearance. It is a general favorite for either home use or market and an excellent table variety. Pkt. 5c: oz. $10 \mathrm{c}$; 1' lb. $20 \mathrm{c}$; lb. $60 \mathrm{c}$, postpaid.

Early Purple Top (Strap Leaf)-A well known early, flat growing variety with best early table turnips and has for years been one of and sweet. This is one of the varicties. I'kt. $5 \mathrm{c} ; 0 \mathrm{z} .10 \mathrm{c} ; 1 / 4 \mathrm{lb} .20 \mathrm{c} ; 1 \mathrm{~b} .60 \mathrm{c}$, postpaid.

Early White Flat Dutch (Strap Leaf)-A medium sized early flat growing turnip, Early White Flat Dutch similar in size and shape to the Early Purple Top, except that it is entirely white with a greenish tinge near the top. Pkt. 5c; oz. 10c; 1/4 1b. 20c; lb. $60 \mathrm{c}$, postpaid.

White Egg A quick growing, pure white, egg shaped variety with small tops. Smooth, White Egg thin skin, firm flesh, mild and sweet. A desirable turnip for either market or home use which will be more generally grown when customers are better acquainted with its many good qualities. Pht. 5c; oz. 10c; 1/1 lb. 20c; lb. 60c, postpaid.

Pomeranian White Globe A large and beautifully formed, globe shaped turnip fine table quality. The leaves also make a salad of excellent quality $1 / 4$ 1b. 20c; 1b. 60c, postpaid.

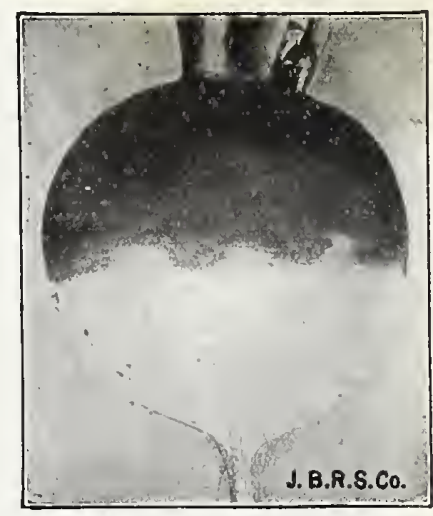

Improved Red Top White Globe

Large White Norfolk A splendid turnip which has long been a standard sort for stock feeding and market. It is clined to be coarse of grain at maturity. It is attened at the top and grows to a large size. The flesh is sweet, but is inLong White Cowhorn As its name indicates, this is a long, white turnip, which grows from 12 to 15 inches long, however, as it is fine grained and above ground, and is generally curved like a cow's horn. The table qualities are good, however, as it is fine grained and sweet, is also a good variety for stock feeding and keeps well for winter use. Pkt. 5c;
oz. $10 \mathrm{c} ; 1 / \mathrm{ll}$ ). 20c; lb. 60c, postpaid.

\section{Yellow Flesh Varieties}

Amber Globe A large globe shaped turnip with solid yellow flesh. A good table turnip, but is probably more yellow flesh turnips. Pent. 5c; oz. 10c; 1/1b. 20c; lb. 60c, It keeps well and is a general favorite with those who prefer the Yellow Aberdeen Although a good table turnip, it is often grown for stock feeding, being a splendid variety for this purpose. Probably no other variety eauals it in keeping through the winter under unfavorable conditions. Has yellow flesh, is very solid, hardy and sweet. Pkt. 5c; oz. 10c; 1/4 1b. 20c; lb. 60c, postpaid.

\section{Salad Varieties}

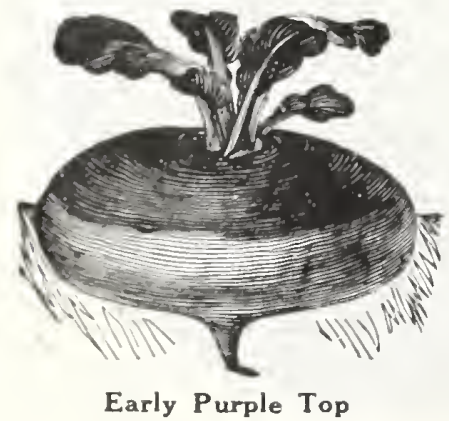

Southern Prize While this makes a white turnip of fair quality, it is used principally for growing salad for winter and spring use. It grows entirely down in the ground, is very hardy, standing the winter without protection. Pkt. 5c; oz. 10c; 1/4 lb. 20c; lb. 50c, postpaid. Seven Top This variety is recommended only for making salad, being splendid of very little value. Is very hardy, standing the coldest winters without protection. Pkt. 5c; oz. 10c;1// lb. 20c; lb. 50c, postpaid.

Mixed Turnip Seeds As many of our customers prefer to sow assorted I'kt. 5c; oz. 10c; 1/4 lb. 20c; lb. 50c, postpaid. 


\section{VEGETABLE PLANTS}

In the proper season we can supply plants of the kinds as listed below and can generally forward promptly on receipt of orders, weather conditions permitting, though plants can rarely be shipped the day that orders are received, as we have to get them in fresh from the gardens. Never order plants shipped by freigit and do not order them sent by mail if it can be avoided. Shipment by express is generally more satisfactory. We exercise every care in packing all orders, and ship only plants that are freshly drawn, but on account of their perishable nature, we cannot guarantee safe arrival. Therefore, all plants are forwarded only at purchaser's risk. We never ship plants the last of the week, unless especially requested, as they would likely lay in the express or post office over Sunday. Should we be sold out of the varieties ordered, we will substitute and send the nearest similar variety we have.

Under no circumstances will plants be sent C. $O$. D.

Cabbage Plants Early Varieties: Wakefields and Cabbage Plants Succession, ready in March, April, May, and November. I'er 50, 30c; per $100,45 \mathrm{c}$, postpaid. Not postpaid, per 50, 20c; per 100, 35c; per 1,000, $\$ 3.00$.

Late Varieties. Late Flat Dutch, Autumn King, Drum. head Savoy. Ready June, July and August. Per 50, 30c; per $100,45 c$, postpaid. Not postpaid, per 50, 20c; per 100, 35 ; per 1,000 , $\$ 3.00$.

Lettuce Plants Ready March, April, May, October and Lettuce Plants November. Varieties: Early White Cabbage, Iceberg, and Big Boston. Per 50, 25c; per 100, $15 \mathrm{c}$, postpaid. Not postpaid, per 50, $20 \mathrm{c}$; per 100, 35c; per $1,000, \$ 3.00$.

Tomato Plants Drawn from seed beds. Varieties: Marglobe, Ponderosa, Stone. Rink, Bonny Best, Brimmer, Per doz. 25c; per 50, 50c; per $100,75 \mathrm{c}$, postpaid. Not postpaid, per doz. $15 \mathrm{c}$; per $50,30 \mathrm{c}$; per $100,50 \mathrm{c}$; per 500 at $45 \mathrm{c}$ per 100 .

Transplanted Plants. Same varieties. Per doz. 35c; per 50, 80c; per 100, \$1.40, postpaid. Not postpaid, per doz. 25 c; per 50,70 c; per $100, \$ 1.25$.

Egg Plants Ready May and June. Black Beauty. Per doz. 30c; per 50, 80c; per 100, $\$ 1.40$, Not pestpaid, per doz. $25 \mathrm{c}$; per $50,70 \mathrm{c}$; per 100 , $\$ 1.25$.

Celery Plants Varieties: Winter Queen, Giant Pascal, White Plume, Self Blanching. Ready July and August. Per 50, 40c; per 100, 75c, postpaid. Not postpaid, per 50, 35c; per $100,60 \mathrm{c}$; per 1,000 . $\$ 5.00$. Pepper Plants Varieties: Royal King, Long Red Cayper $100, \$ 1.00$.

Cauliflower Plants Ready March, April. 50 for $75 \mathrm{c}$; Dostpats per 100, \$1.25, postpaid. Not postpaid, per 50, 65c; per $100, \$ 1.10$.

Sweet Potato Plants Ready May and June, HanSover Yellow Variety. Per 100,

Varieties- Porto Rico postpaid. Not postpaid, per $100,45 \mathrm{c}$; per $1,000, \$ 4.00$.

Asparagus Roots Washington, two years old. Ready Roots November 1st until May. Per 50 $\$ 1.15$; per $100, \$ 2.00$, postpaid. Not postpaid, 50 for $\$ 1.00$; per $100, \$ 1.75$; per $1,000, \$ 10.00$.

Rhubarb Roots Ready November 1st until May. Rhubarb Roots 20c each; per doz. $\$ 1.50$, postpaid. Not postpaid, each $15 \mathrm{c}$; per doz. $\$ 1.25$; per $100, \$ 8.00$.

Sage Roots Feady March and April. Each 20c; per $\frac{\text { Sage Roots }}{15 \mathrm{c} ; \text { per doz. } \$ 1.25 \text {. }}$. 1.50 , postpaid. Not postpaid, each

Thyme Roots Ready March and April. Each 20c; each 15c; per doz. $\$ 1.25$.

Horse Radish Roots Ready November to May. Per $\$ 1.50$, postpaid. Not postpaid, per doz. $35 \mathrm{c}$; per 50 , 100 , per $100, \$ 1.40$

\section{RUTA BAGA}

Improved Purple Top Yellow We consider this so far suthat we do not offer any other variety. Our stock is the best American strain, grown from roots, which have been careiully selected for large size, uniform shape and exceptional quality. This is by far the best Ruta Baga for either table use or stock feeding. Is hardy, vigorous, has f:rm, sweet flesh, an excellent keeper and yields enormously under proper cultivation. Farmers should raise more Ruta Bagas for feeding stock. They are easy to grow, are healthy and nutritious, and stock eat them with relish. Oz. 10c; 1/t lb. 20c; lb. 65c, postpaid.

\section{D. \& B.'s Garden and Lawn Enricher Strictly an Or-}

tirely free from chemicals. Gives excellent results for use on vegetables, shrubs, fruit trees and lawns. 5 lbs. $40 \mathrm{c} ; 10 \mathrm{lbs} .65 \mathrm{c} ; 25 \mathrm{lbs}$. $\$ 1.00 ; 50 \mathrm{lbs}$. $\$ 1.75 ; 100$ lbs. $\$ 3.00$.

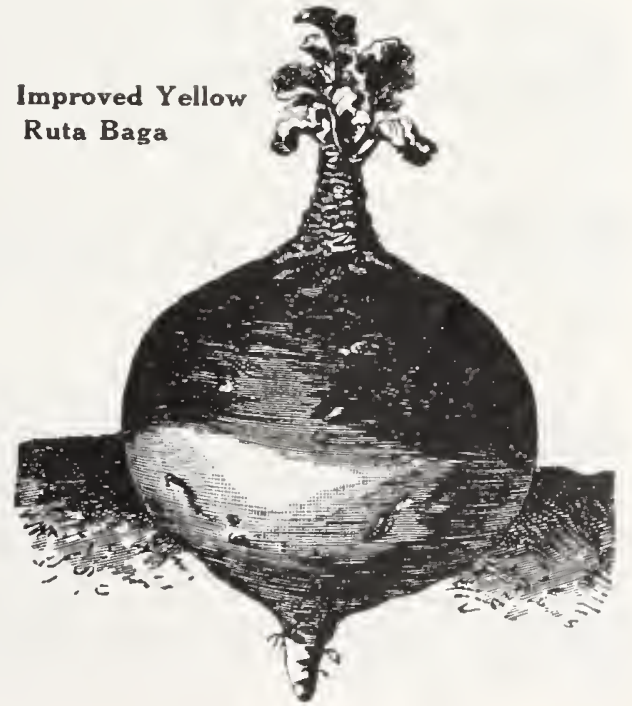




\section{IRISH POTATOES}

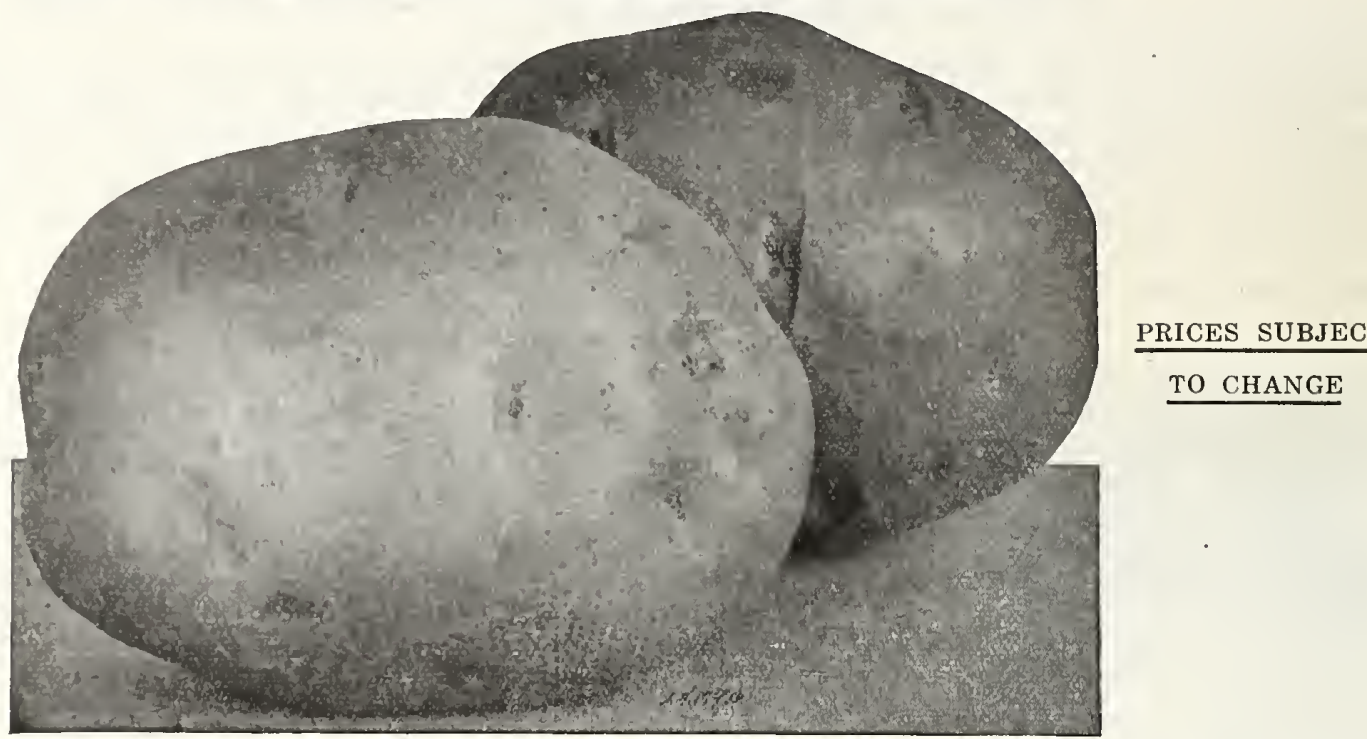

CULTURE.-Irish Potatoes should be planted in the spring as early as the ground can be prepared. In rich soil, rows 3 feet apart, placing the cut tubers 15 inches apart in the row. Use a well-balanced Potato Fertilizer, which should contain not less than 5 per cent of Potash; 8 per cent is better on most soils. Stable manure has a tendency to make Potatoes grow rough and scabby. As a fertilizer for use on Potatoes there is nothing better than D. \& B.'s Potato and Berry Grower.

For late crop, plant from June to August. We recommend sprinkling Powdered Sulphur on Potatoes when they are cut for planting, which is a preventive of blight and scab and also prevents bleeding, which weakens the vitality of the Potato and is in other ways injurious. Many of our largest Potato planters always use Sulnhur with the best results-1 pound is sufficient for 50 pounds of Potatoes. For price of Sulphur, see page 63 . Potatoes should be cut several days before planting as the cut should heal somewhat before putting them in the ground. In the Potato growing sections of Maine, the most successful growers cut their Potatoes 4 to 6 weeks before planting.

Our Potatoes are grown under the personal supervision of the most reliable and experienced growers and great care is exercised from the selecting and planting of the stock to the harvesting, grading and shipping of the crop. Customers should keep in mind that our Potatoes are Seed Potatoes, grown especially for planting, and should not be compared with ordinary commercial Potatoes so often offered as seed stock.

Irish Cobbler This well known Potato is now more largely grown both by market and home gardeners for early crop than all other varieties combined. It is an extra-early large white Potato; hardy and vigorous grower, having very few small Potatoes in a hill. Our strain of this Potato is the best stock obtainable.

I’rince Edward Island Grown-Certified-Pk. 50c; bu. \$1.60; 150-lb. sack \$3.65.

Virginia Grown-Selected-I'k. 45c; bu. $\$ 1.60 ; 150$-lb. sack $\$ 3.40$.

Maine Grown-Selected-Pk. $45 \mathrm{c} ;$ bu. $\$ 1.50 ; 150-\mathrm{lb}$, sack $\$ 3.25$.

Spaulding No. 4 Rose A strain of the a smoother skin and is of much better table quality, a better yielder, and keeps well. Virginia grown. l’k. 10c; bu. \$1.50; 150-lb. sack \$3.15.

\section{Red Bliss Triumph While not as generally} Red grown as formerly, this Potato is still a favorite with some growers. It is probably the earliest variety. It is very hardy; a strong grower and a fine yielder. Grows to a good size and has a smooth pink skin.

I'rice on application.

\section{D. \& B.'s Snow This Potato is somewhat like} D. \& B.'s Snow the Green Mountain and matures at about the same time. It may be used as a second early or late crop Potato. It yields abundantly of large pure white Potatoes of unexcelled table qualities, and is also a splendid keeping Potato. Customers who have grown this Potato are very enthusiastic about its eating qualities and consider it the best Potato grown. It brings the highest market prices. As a baking Potato it has no superior. Recommended only for late planting. Ask for price in season.

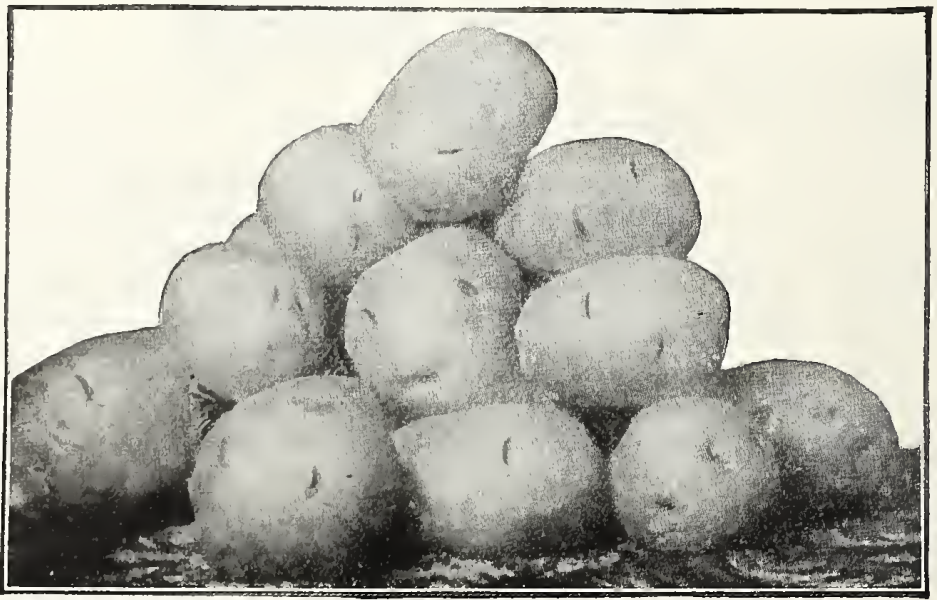

Irish Cobbler 
Green Mountain A well-known large, handsome, pure white Potato, for main or late crop; a prolific yielder and Green Mountain invariably of fine table quality, cooking dry and mealy. A standard variety for late crop; matures about 2 weeks later than the Irish Cobbler. Ask for price in season.

Improved Peach Blow This well known variety is the hardiest, largcst yielding and best keeping variety of any in scason. Cold-Storage Potatoes We will have a nice stock of the leading varieties kept in cold storage for late planting

\title{
SWEET POTATOES
}

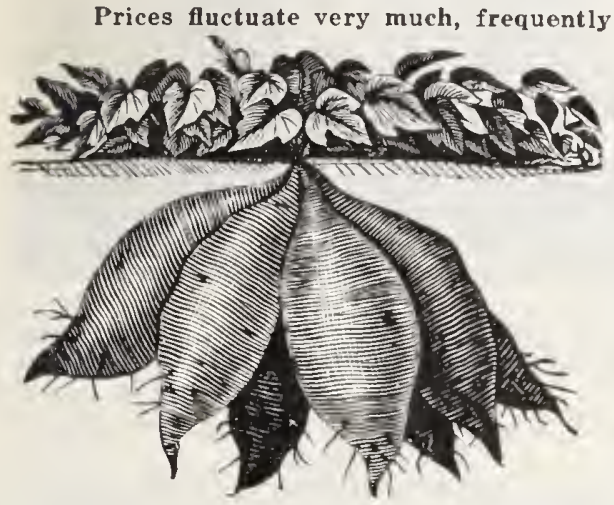

\begin{abstract}
CULTURE-These should be planted in hotbeds in April and kept well watered. As soon as the plants are ready and danger of frost is past in May or June they should be transplanted to rows 3 feet apart, setting the plants 16 inches apart in the row.

Seed Sweet Potatoes are very perishable, and will not keep long after being taken out of storage, especially in damp or rainy weather. For this reason we cannot carry them in stock for any length of time, but get them in from day to day. We ship only good, sound Potatoes, in firm condition, but we cannot guarantee safe arrival of anything so perishable, though we are very careful in packing and shipping them.
\end{abstract}

Porto Rico, or Cuban Yam This Potato has been grown extenand was introduced by us into this section some years ago. It has golden yellow flesh with pinkish skin, and is the largest yielding potato we know of. It is also by far the best keeping Potato known. The longer it is kept the sweeter it gets.

Hanover Yellow The leading Yellow Potato in Hanover County, which is noted for its excellent Sweet Potatoes. Pumpkin Yam, or Nancy Hall Has yellow flesh, hence its name Pumpkin Yam. It cooks soft, juicy and sweet,

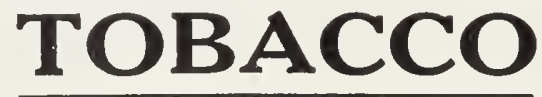

Our Tobacco Seeds are grown in the best Tobacco land in the Virginia Tobacco Belt. They are grown under improved scientific methods by reliable men under the supervision of a Tobacco grower of many years experience. The seed we offer is saved from only the best plants, cleaned of all filth and imperfect seeds, and no pains or expense is spared to produce the very best Tobacco Seed that can be had at any price.

\section{TREATED TOBACCO SEEDS}

All our Tobacco Seeds are treated as recommended by the Virginia Agricultural Experiment Station. This treatment is to prevent wildfire, leaf spot and other tobacco diseases.

CULTURE-Sow in February and March in a rich and perfectly clean bed, from which all seeds and insects have been destroyed by burning. Protect from flies with plant bed cloth, and transplant about June to highly fertilized soil, $31 / 2$ to 4 feet each way. Cultivate thoroughly and guard well against suckers and worms.

Price of all Varieties-Pkt. 10c; oz. $40 \mathrm{c}$; $1 / 4$ lb. $\$ 1.25$, postpaid.

Sweet, or Little Oronoko This is a very superior Oronoko Tobacco; the leaf is long, with a good breadth; has a cured, the best natural chewing leaf small stem and very fine texture; used for first-class plug fillers, and makes, when sunknown, especially liked by some for its earliness and ability to stand upon the hill for some time without becoming overripe. In all respects an ideal manufacturing Tobacco.

Big Oronoko The leaf is large, broad, of handsome appearance, cures well and possesses a great deal of weight and

Lizard Tail Oronoko This is said to be the heaviest of the Oronokos. It has a large number of leaves to the plant which are of good width and length. It is a hardy grower and of good quality, is best probably has no superior for that purpose. White Stem Oronoko A good variety for wrappers. Makes a bright leaf of good width and length. Well adapted

Adcock One of the best varieties for growing on poor land. The leaf while not long, is unusually broad for its length, Adcock the bright colored Tobacco making fine cigarette cutters. Best adapted to light gray or sandy soils.

Improved One-sucker Plants grow to medium large size, the leaf medium size, fine grained and of excellent quality. a dark, heavy export Tobacco. Long noted for its unusually small growth of Tobacco, but is especially adapted to make Gold Leaf As its name indicates, this is a bright Tobacco and a great favorite with the growers of Bright Tobacco. Gold Leaf The leaf is long and broad, similar in shape to that of the Warne, but is of a finer texture. It is said to be the easiest variety to cure up a rich Golden Yellow and retain its fine texture. It is also said to yield more pounds per acre than any other variety of Bright Tobacco, but it is not recommended for growing in other than Bright Tobacco Sections,
where its popularity increases with each season.

Hester A well known and popular variety. Among its good qualities may be noted its size, shape, texture, habit of early is a saying maturing, and its adaptability to an almost limitless range of soils and climates. It is by far the surest. There 


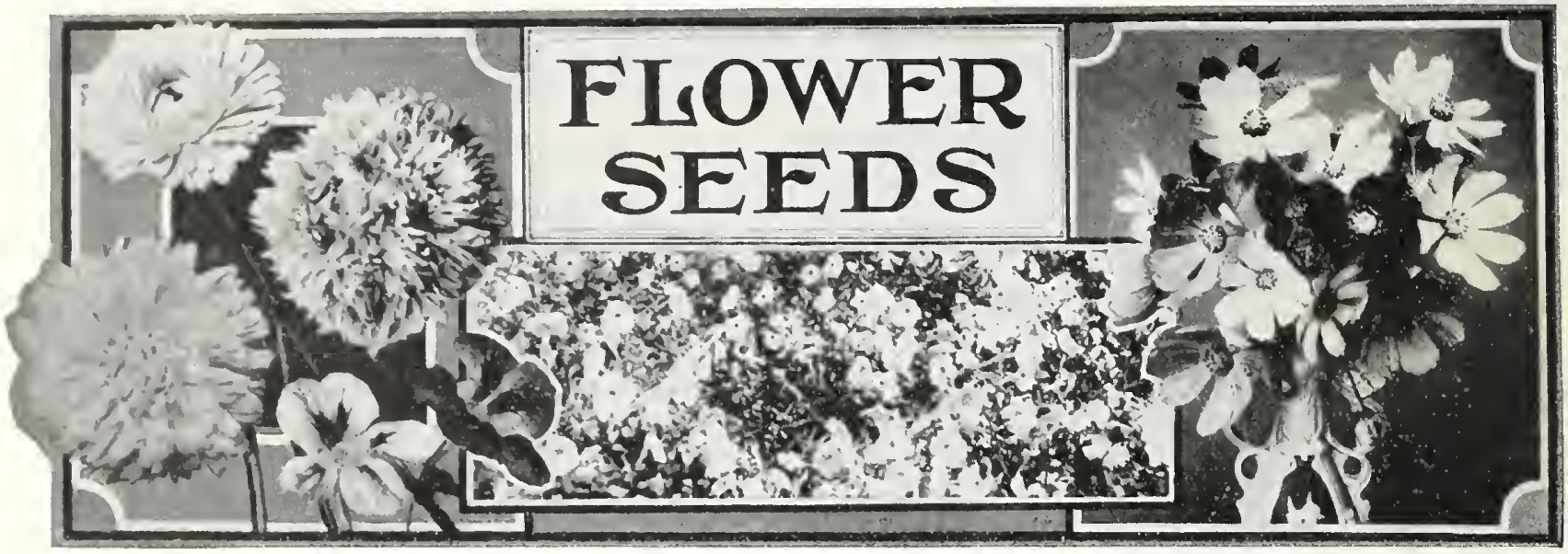

We have endeavored to make our list of Flower Seed as complete as possible by a careful selection of the best sorts, so that our customers would not get confused among a long list of varieties, many of which have no special merit. We list only the varieties which we consider the best of their kind.

We do not index our different varieties of Flower Seeds, but have arranged them in alphabetical order so the varieties wanted can be easily found.

The letter "A" after the name of the flower indicates that the flower is an annual and blossoms only the first year it is sowed and then dies, so the seeds of these should be sowed each year. The letter "P" indicates that the variety is a perennial and usually blooms the following year after sowing and continues blooming for several years thereafter.

Most Flower Seeds are quite small and delicate and shouid not be sowed outside until the warm weather is permanently settled and the ground becomes thoroughly warm. To have flowers earlier the seed may be started in boxes indoors and transplanted outside after warm weather sets in. The soil for the boxes or seed bed should be rich, soft and mellow and thoroughly pulverized, covering the seed very slightly or by pressing them firmly into the soil with the fingers. Do not make the mistake of covering too deep as small seed cannot germinate if covered deeply.

As a general rule it is best not to water the beds until the plants appear and then only with a slight mist until the plants are larger. Cultural directions of all varieties are printed on each package.

For Climbing Vines and Flowers see page 38.

\section{All varieties of Flower Seeds priced at 10c per packet are sold for Cash with Order. 3 pkts. for $25 \mathrm{c}, 7$ pkts. for $50 \mathrm{c}, 15$ pkts. for $\$ 1.00$, postpaid. Your selection.}

\section{Acroclinium- \\ Everlasting (A)}

A very pretty, half-hardy annual, producing white and rose-colored double daisy-like flowers about $1 \frac{1 / 2}{2}$ inches in diameter. These are the "Immortelles," so desirable for wreaths and winter bouquets. Height 15 inches. Double Mixed. Plkt. 10c; oz. 60c.

\section{Ageratum (A)}

A beautiful half-hardy annual. The flowers are borne in dense clusters, and are very attractive in the garden, being covered with bloom nearly all summer. Mixed colors. Pkt. 10c; oz. $60 \mathrm{c}$.

\section{Alyssum (A)}

A hardy annual, which begins to

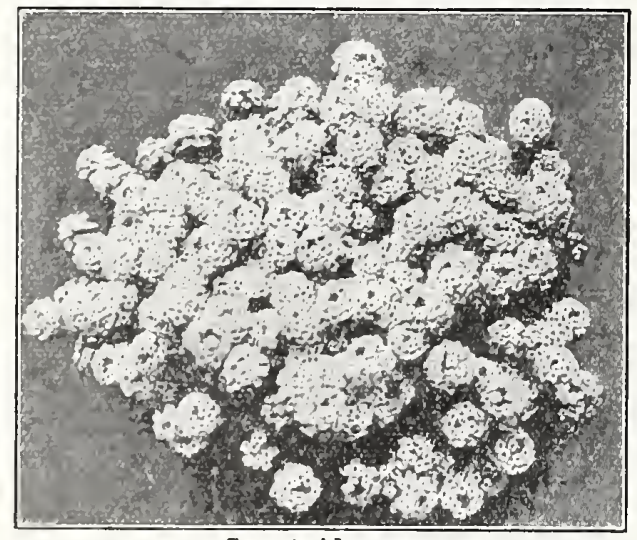

Sweet Alyssum
Amaranthus (A)

These plants afford brilliant contrasts of color, being useful for tall borders and groups also where foliage effects are desired. The leaves and stems are of different shades of red blended with green. 2 to 3 feet high.

Caudatus. (Love Lies Bleeding)Light yellowish green foliage; long, drooping crimson flower spikes. Pkt. $10 \mathrm{c}$; oz. $25 \mathrm{c}$.

Tricolor. (Joseph's Coat) -A hardy annual with leaves of red, yellow and green; especially brilliant if grown in rather poor soil. Pkt. $10 \mathrm{c}$; oz. 60c.

\section{Anemone-

Wind Flower (P)

flower when very young, and is literally covered nearly all the season with its sweet white flow. ers. It is especially adapted to borders or for rock work in the summer, and may be used effectively in window boxes for winter blooming.

Little Gem. This is the prettiest variety, being so dwarf and full of bloom that it has been aptly named "The Carpet of Snow." Four inches high. Pkt. 10c; oz. $60 \mathrm{c} ; 1 / 4 \mathrm{lb}$. $\$ 1.75$.

Sweet. The old garden favorite familiar to all. Being of trailing habit, it is better than the little $\mathrm{Gem}$ for rockeries or window boxes. Pkt. $10 \mathrm{c} ; 0 z .30 \mathrm{c} ; 1 / 4 \mathrm{lb}$. $\$ 1.00$.
These are hardy perennials, blooming in the spring or fall, producing semi-double large poppy-shaped flowers 2 to 3 inches across, in attractive colors. Mixed. Pkt. 10c; oz. $\$ 1.75$.

\section{Aquilegia-Columbine (P)}

Grows about 2 feet high and bears a great variety of colors on long, smooth stems. Easy to grow. Mixed. Pkt. 10c; oz. $75 \mathrm{c}$. 


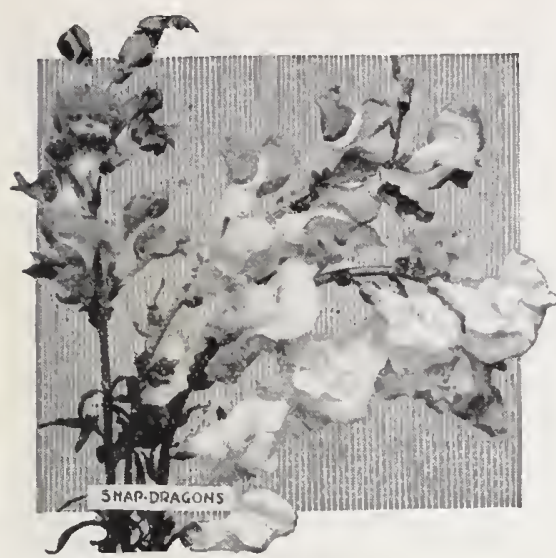

Snapdragon

\section{Antirrhinum $\overline{\text { Snapdragon }}$}

(P)

Well known showy and useful border plants, producing flowers of a great variety of brilliant and handsome colors. Very effective in beds, succeeding in any good garden soil. They are also very desirable for cutting, as the spikes of bloom are borne well above the dark glossy leaves, and keep fresh for a long time. Snapdragons have become immensely popular in recent years and can be easily grown from seed. In colors: White, Scarlet, Silver Pink, Yellow. Each, pkt. 10c; 1/4 oz. 35c; oz. $\$ 1.00$.

Finest Mixed. Pkt. 10c; oz. 85c.

\section{Asters (A)}

These well-known, beautiful and popular annuals are very desirable for bedding, being in bloom when most other plants are over. Very useful for cut flowers and bouquets.

Victoria. These are extra large flowering, desirable for bedding, being in bloom when most other plants are over. Very useful for cut flowers and baskets. In colors: White, Crimson, Lavender, Rose. Each, pkt. 10c; $1 / 402.50 \mathrm{c} ; 0 z . \$ 1.50$.

Victoria Mixed. Pkt. 10c; 1/4 oz. 50c; oz. \$1.50.

German Quilled. (China Aster Mixed)-The familiar double Aster with quilled petals. Exceedingly showy and excel-

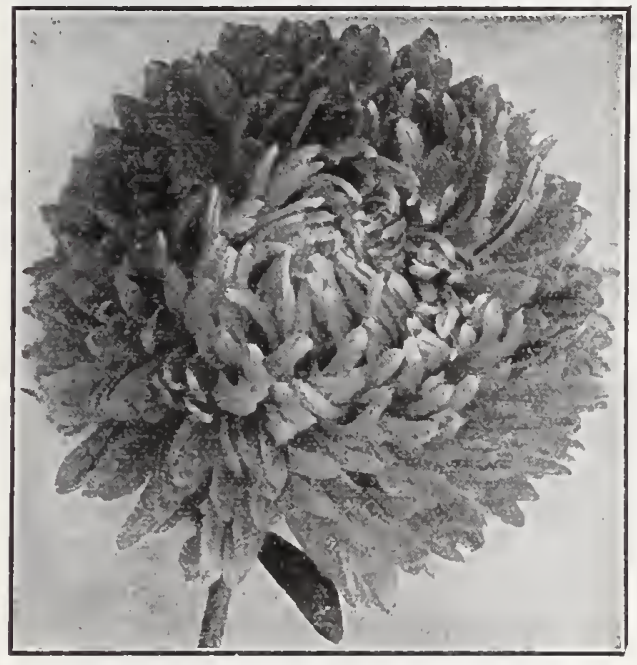

Aster lent for cutting for vase d e corations. The la rge, b rill i a nt, daisy - like flowers with yellow centers are produced in profusion. Pkt. $10 \mathrm{c} ; 1 / \mathrm{oz}$. $25 \mathrm{c}$; oz. $75 \mathrm{c}$. Giant Comet Extra Fine $M$ i $x$ e d. Single-A c a refully proportioned mixture of various colors, the petals of which are very long and recurved, having $t \mathrm{~h} e$ effect of the finest Chrysanthemums. They are varied and beautiful colors and one of the most popular sorts. Pkt. 10c; 1/4 oz. 40c; oz. $\$ 1.25$.

\section{Bachelor's Buttons-Globe Amaranth (A)}

A well-known and popular everlasting flower, which forms bushy plants about 2 feet high and bearing sometimes hundreds of flowers. Excellent as border plants, and very useful for winter decorations. If cut when well matrred will retain their beauty throughout the winter. Mixed. Pkt. $10 \mathrm{c} ;$ oz. $40 \mathrm{c}$.

\section{Balsam-Touch-Me-Not (A)}

Also known as "Lady Slipper." A tender annual with brittle stems and foliage, grows about 12 inches high. Flowers both single and double, in bright colors and variations; are wax like and very attractive.

Double White. Pkt. 10c; oz. $65 \mathrm{c}$.

Double Mixed. Pkt. 10c; oz. 50c.

\section{Candytuft (A)}

Popular favorites, flowering profusely the whole summer. Very valuable for edgings and borders, fairly covered with masses of white and various colors. Height 1 foot. Of easy culture.

White. Pkt. 10c; oz. $50 \mathrm{c}$.

Fancy Mixed. Pikt. $10 \mathrm{c} ;$ oz. $30 \mathrm{c}$.

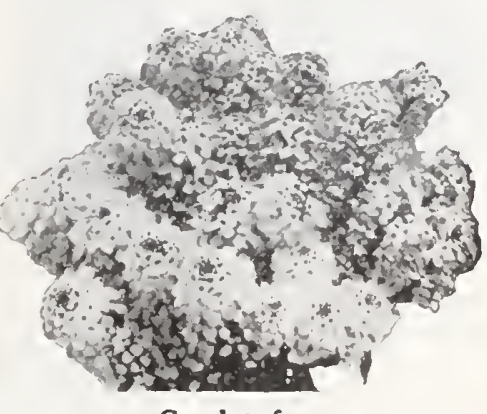

Candytuft

\section{Calendula, Pot Marigold (A)}

A very hardy annual, one foot high. Has showy flower. blooming until frost and producing a fine effect in borders. O easy culture and is desirable for rather inferior soils, wher less sturdy flowers do not thrive.

Finest Double Mixed. Pkt. 10c; oz. 25c.

\section{Calliopsis, or Coreopsis (A)}

Finest Double Mixed. Beautiful, showy summer bedding annuals, with large, bright flowers of golden yellow, varied with rich brown. Excellent for cutting and decorations. Pkt. $10 \mathrm{c}$; oz. 30c.

\section{Carnations (P)}

These well known flowers are easily grown from s e e d, a n d very fre blooming, the flowers being bright $\cdot$ colored and with a most deli cious clove - $1 \mathrm{ike}$ f $r$ a g rance. Excellent bloomers in the garden or for winter flowering. Marguerite. Anextra-vigorous $\mathrm{r}$ a c e. e s p e ially adapted for out - of-door

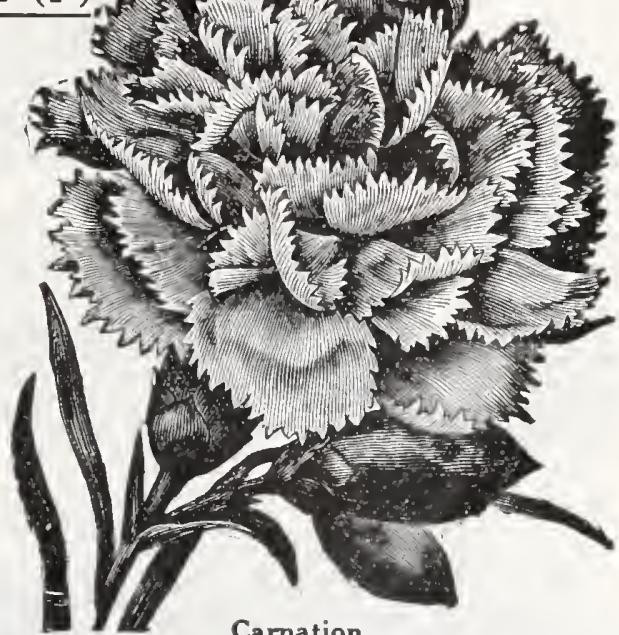

culture. The plants are trim in habit, perpetual and flower abundantly in 5 months from sowing the seed. Highly fragrant beautiful double flowers. Pkt. 10c; $1 / 4$ oz. $40 \mathrm{c}$.

Double Scarlet. Pkt. 10c; 1/4 oz. 75c.

Double Pink. Pkt. 10c; 1/4 oz. 75c.

Double White. Plt. $10 \mathrm{c} ; 1 / 4$ oz. $75 \mathrm{c}$.

Double Mixed. A mixture of all colors and types. Pkt. $10 \mathrm{c} ; 1 / 4$ oz. $50 \mathrm{c}$. 


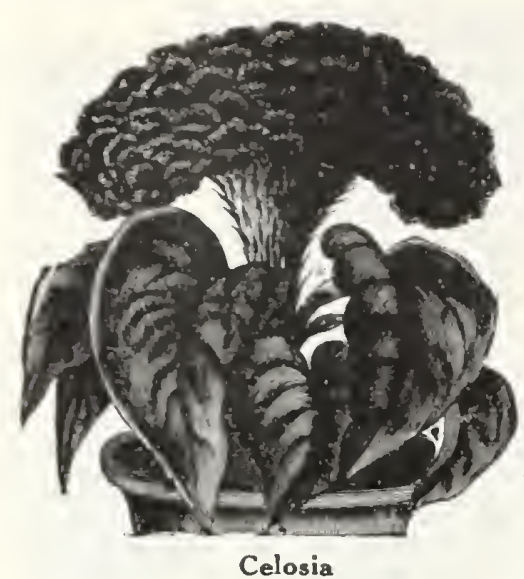

Celosia

\section{Canna (P)}

Stately, ornamental plants, producing clusters of large flowers of the most intense, varied and brilliant colors. Very desirable for greenhouse or bedding outdoors. Plant the seed in February, first soaking them for a day in warm water. In August the plants will come into bloom and continue to flower very freely until cut down by frost. Store the roots in cellar in winter.

Tall Mixed. Pkt. 10c; oz. 25c.

Crozy's Dwarf Mixed. Pkt. 10c; oz. 25c.

Canna Roots. See page 40.

\section{Celosia-Cock's Comb (A)}

A half-hardy annual, growing 6 to 8 inches high, bearing a wide wavy blossom that reembles a cock's comb. Fine for massing or border work.

Childsi Crimson. (Chinese Wool-flower). A unique form of feathered cockscomb, of a rich bright red color, forming large globular heads like balls of brilliantly colored wool. Pkt. 10c; $1 / 4$ oz. 50c.

Feathered. A handsome foliage plant producing large, showy, graceful, feathery blooms. 2 to 3 feet. Pkt. 10c; oz. 50c.

Empress. Dark foliage. Crimson Comb. Pkt. 10c; 1/4 oz. 65c.

\section{Canterbury Bells-Campanula, Cup and Saucer (P)}

A handsome, hardy biennial of stately growth, rich color and profuse bloom. Succeeds best in light, rich soil, and in the fall should be transplanted or thinned to 18 inches or 2 feet apart and given some protection in severe winter weather. Has large bell-shaped flowers, which are strikingly effective. Colors white and various shades of violet, rose, lilac and blue. Height 2 to 4 feet. Une of the wild forms of Campanula is the "Blue Bell of Scotland."

Single Mixed. Pkt. 10c; 1/4 oz. 20c; oz. 70c.

\section{Centaurea Gymnocarpa-Dusty Miller (P)}

Valuable because of its silvery foliage and graceful drooping habit of growth. Half-hardy perennial. One-half to 2 feet high. Pkt. 10c; oz. 60c.

\section{Centaurea Cyanus-Corn Flower (A)}

Also known as "Blue Bottle" and "Ragged Robin." This old-fashioned flower is still a favorite for cutting, is of easy culture and blooms freely from July until fall. All colors mixed. Pkt. 10c; oz. 40c.

\section{Chrysanthemum (A)}

These annual Chrysanthemums have a charm of their own. The blooming season is from very early summer until frost, and their gay colors make beds or borders attractive during those hottest weeks of summer when flowers are apt to be scarce.

Finest Mixed. Pkt. 10c; oz. 40c.

\section{Coleus (P)}

Probably the best known and most popular of ornamental foliage plants. The leaves are of many shades of color and have a rich velvety appearance of extraordinary beauty. No lawn should be without these decorative plants. Tender perennial. Finest varieties. Mixed. Pkt. 10c; $1 / 4$ oz. $\$ 1.50$.

\section{Cosmos (A)}

These well - known flowers are of easy culture and are almost indispensable for cutting and garden decorations, their lovely blossoms being produced in greatest profusion after most other flowers have succumbed to frost. Few flowers have grow more into popularity in late years than the Cosmos, and we recommend them to all wanting large plants in their gardens.

Mammoth Flowering. The flowers are double the size of the old, large-flowering Cosmos, measuring from 3 to 4 inches across. The petals are large, overlapping, forming perfectly round flowers, deeply ribbed and of good substance. In separate colors: White, Pink, Crimson. Each, Pkt. 10c; oz. 50c.

Mixed Colors. Pkt.

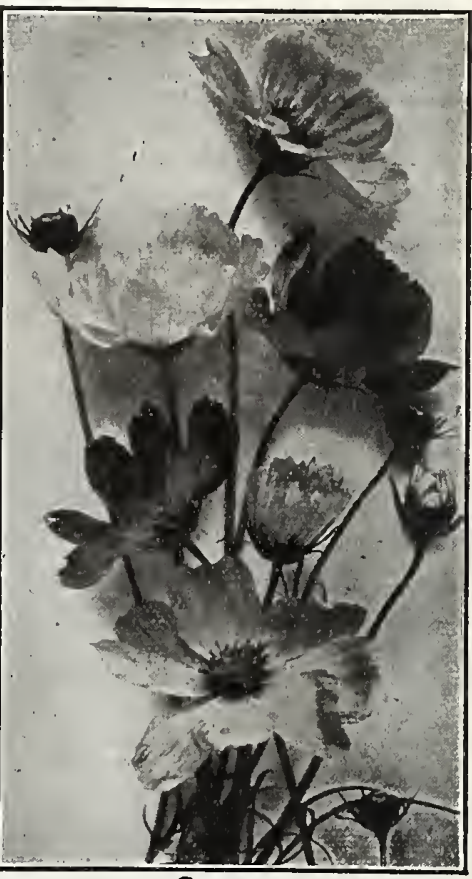

10c; oz. 40c.

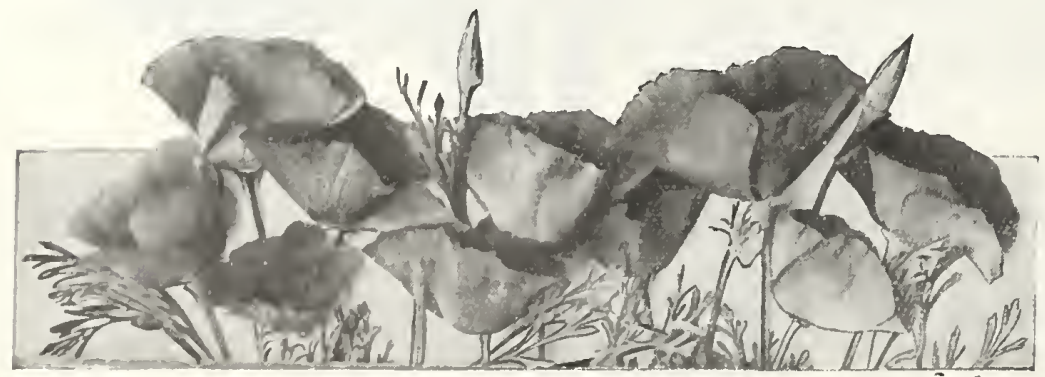

Escholtzia-California Poppy

\section{Delphinium or Perennial Larkspur (P)}

The perennial varieties of Delphinium are usually taller than the annual sorts and the flowers much larger, though they do not bloom until the second season. The beautiful, graceful flowers are borne on long spikes. Mixed. Pkt. 10c; 1/4 oz. 50c. 


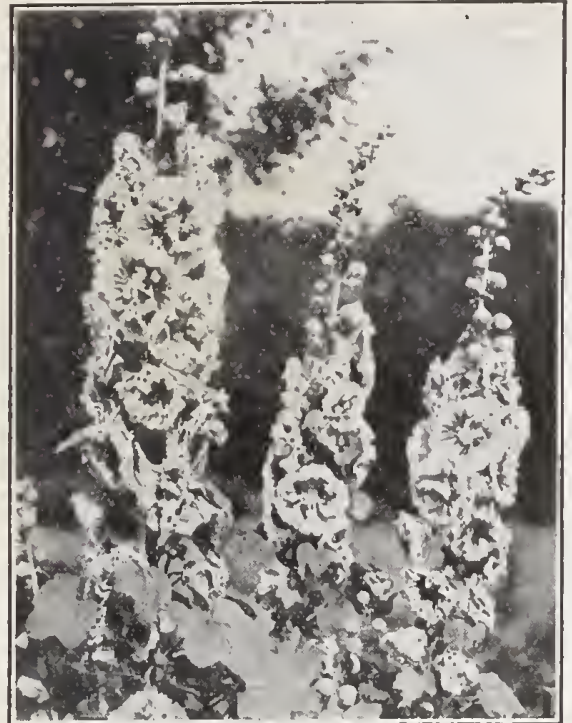

Hollyhock
Dahlia (A)

The Dahlia has always been a favorite for autumn flowering. The flowers are so symmetrical and perfect and the range of colors so large and varied that they will always be popular where display is wanted. This popular flower may be had in the greatest variety and be a u ty from seed. If planted early and given protection in the spring they can be made to flower the first season. During the winter the roots can be taken up and stored out of reach of the freezing weather and replanted the following spring.

Double Large Flowering Mixed. Pkt. 10c; 1/2 oz. \$1.00.

Dahlia Roots. See page 41.

\section{Daisy (P)}

These are charming little plants for edging and borders. The Daisy has been so far improved by selection and careful cultivation that good seed will give at least 80 per cent of double flowers that are as large as any of the named sorts that are propagated by the division of the roots, and are sold at high prices. The plants bloom well in the house and are splendid for early spring and summer flowering when planted in a slightly shaded situation. Tender perennials. 6 inches high. Double Mixed. Pkt. 10c; 1/4 oz. 75c.

\section{African Daisy (A)}

This very showy, annual Daisy comes from South Africa. The bushy plants grow 12 to 15 inches high and bear in great profusion daisy shaped flowers varying in color from the purest white through the various shades of yellow and orange to rich salmon. Flowers $2 \frac{1}{2}$ inches across with dark centers, surrounded by a black disc. Splendidly adapted for beds and borders. Pkt. 10c; 1/4 oz. 35c.

\section{Dianthus, or Pinks (P)}

These popular flowers, commonly known as Chinese and Japanese Pinks, have been for a long time very popular, and deservedly so. In diversity of rich and beautiful markings they have but few rivals, and in case of culture, freedom of bloom and almost certain satisfactory results they stand close to the Nasturtium. Hardy biennials, blooming the first year from seed. So easily grown from seed as to be rarely treated as biennials.

D. \& B.'s Dianthus Chinensis. The familiar Chinese or Indian Pink, easily grown and very showy. Our mixture contains an unusually large assortment of colors in double varieties. Pkt. 10c; oz. 50c.

Dianthus Heddewigii. Large flowering single mixed. A splendid mixture of single flowers of the best shades and beautifully marked. Pkt. 10c; oz. 75c.

\section{Digitalis, or Fox Glove (P)}

A stately old-fashioned border plant, affording dense spikes of brilliant-colored flowers, which are terminal and half as long as height of plant. Colors white, lavender and rose. Does not usually bloom until the second year. Thrives best in cool, shady locations. Fine Mixed. Pkt. 10c; oz. 75.

\section{Escholtzia-California Poppy (A)}

The beautiful State flower of California. Also known a the "Poppy of Flanders Field." It blooms almost continuously throughout the season. A bed of these in full bloom gives a brilliant color effect. The foliage is finely cut and has a bluish tinge, delicate and very attractive. They are of the easiest culture, can be sown in any soil, but the better the soil the larger the plants and blossoms. It is best to sow the seed in the garden where the plants are to remain, as they do not transplant easily. Our mixture is brilliantly mixed, rich in shades of crimson, pink, orange and scarlet. Pkt. 10c; oz. 50c.

\section{Euphorbia-Snow on the Mountain (A)}

Easily grown annual with beautiful ornamental foliage, prettily veined and margined with white. Very showy. Pkt. $10 \mathrm{c} ; \mathrm{oz} .60 \mathrm{c}$.

\section{Forget-Me-Not-Myosotis (P)}

The favorite old border plant that succeeds best in moist situations. It comes into blooming early and the little starshaped flowers appeal to every heart. Hardy perenuials. Pkt. $10 \mathrm{c} ; 1 / 4$ oz. 25c.

\section{Four o'Clock-Marvel of Peru (A)}

A well-known favorite plant, bearing freely funnel-shaped white, red and striped flowers, which open about four o'clock in the afternoon, remaining open all night; and usually are closed before noon the next day. Sow seed in spring in open ground in any good garden soil. The plants should be given plenty of room, about three feet apart. Pkt. 10c; oz. 20c.

\section{Gaillardia (P)}

A very showy, hardy, garden plant, with brilliant flowers in scarlet and yellow, blended and shaded. Blooms freely from early summer till autumn. Grows one and one-half to two feet high, and the blossoms are borne on long, slender stems.

Grandiflora Mixed. Single perennial variety of varying shades of reddish brown, scarlet and orange. The largest of these species, excellent for cutting. Pkt. 10c; oz. 60c.

\section{Geranium (P)}

Geraniums may be easily raised from seed by sowing in boxes. A packet of seed will furnish a large number of plants. They bloom successively until frost, afterwards making a splendid house plant. The blooms are of brilliant colors, the leaves being sweet scented and exquisitely marked. Mixed. Pkt. 15c; 1/4 oz. 75 .

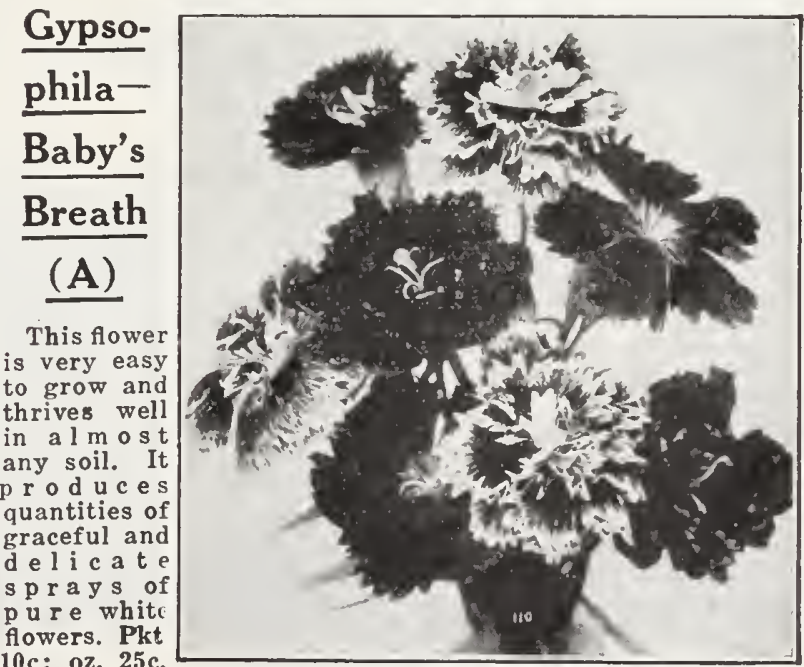

$10 \mathrm{c} ; 0 \mathrm{z} .25 \mathrm{c}$

Dianthus or Pinks 


\section{Heliotrope (P)}

The delicate tinted and fragrant blossoms of this beloved little flower are so well-known that any attempt at description would be superfluous. It is adapted to both bedding and house culture, requiring little attention. By sowing indoors early in the spring and transplanting into small pots the plants may be made so strong and stocky that they will be in full bloom soon after being set in the garden.

Large Flowering Mixed. Pkt. 10c; $1 / 4$ oz. $50 \mathrm{c}$.

\section{Helichrysum-Everlasting} Flower (A)

This is also known as straw flower, one of the best of the everlasting flowers. They should be gathered when coming into bloom and suspended with the heads downward in a cool place. When dry they are used for winter bouquets.

Double Mixed. Pkt. 10c; 1/2 oz. 40c.

\section{Hibiscus (A)}

Africanus. A free blooming flower of easy culture, producing flowers of large size, 3 to 4 inches across. White with black center. Very desirable for mixed beds or borders. Pkt. 10c; oz. 50c.

\section{Hollyhock (P)}

For a background to a flower garden, nothing is better than this tall, old-fashioned garden favorite. The large, richly colored blossoms, about 3 inches across, ranging from deep yellow and réd to pure white, are set as rosettes around the strong growing flower stalk. The Hollyhocks of today are entirely different and more beautiful than the plant of years ago, being much more compact in growth, the flowers larger, more richly colored and of better form. Sow the seed in May or June, in open ground, and in the autumn, when the plants have made five leaves, transplant to permanent position 2 or 3 feet apart. The following summer they will bloom.

They grow to a height of 5 feet, and if the stalks show a disposition to fall, tie stakes to them to hold them up. The Double Hollyhock is the most desirable.

Double Superb Mixed. Pkt. 10c; 1/4 oz. 30c.

\section{Kochia Summer Cypress or Mexican}

\section{Fire Bush (A)}

A rapid growing plant, highly ornamental. The feathery light green foliage turns to a fiery red in autumn. Makes a fine summer hedge. Pkt. $10 \mathrm{c} ; 0 \mathrm{z}, 25 \mathrm{c}$.

\section{Lantana (P)}

Well known shrub, splendid for bedding as it is constantly in full bloom. The flower stem is crowded with a large truss of orange and red verbena-like flowers of varied hues. Tender perennial, Mixed. Pkt. 10c; oz. 60c.

\section{Larkspur (A)}

The Larkspur is one of the handsomest and most useful of plants. The colors are extremely beautiful and in mixed borders its profuse masses of purple, white and red, show splendidly and for large gardens is invaluable.

Double Dwarf Mixed. Pkt. 10c; oz. 50c.

Double Tall Mixed. Pkt. 10c; oz. 50c.

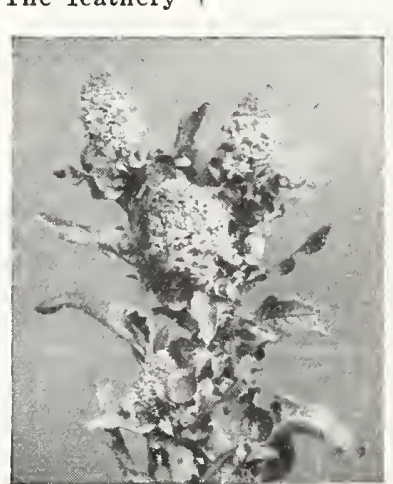

Mignonette

\section{Lobelia (A)}

Profuse blooming little plants, of great value for edging, hanging baskets or vases. It is completely covered with flowers for a long time. If given plenty of water they may be kept in flower all summer.

Mixed Colors. Pkt. 10c; 1/4 oz. 35c.

$$
\frac{\text { Love-in-a-Mist, }}{\text { Nigella (A) }}
$$

A hardy annual, one foot high, with finely cut foliage. Oddly shaped blossoms in blue and white, and curious seed pods. Of easy culture.

Mixed. Pkt. 10c; oz. 40c.

\section{Marigold (A)}

A hardy annual, shrubby plant in dwarf and tall varieties, growing from 6 inches to 3 feet high. Foliage bright green, deeply cut, and graceful. The flowers are various shades of yellow and brown. These tall growing varieties are very valuable for large bedding or background work, and no flower garden seems complete without this fine old-fashioned plant.

African Mixed. Large double blossoms. Pkt. 10c; oz. 40c.

Tall French Finest Double Mixed. A mixture of all the various shades. Pkt. 10c; oz. 50c.

\section{Ice Plant (A)}

A pretty little trailing flower for baskets or boxes, grows about six inches; flowers white or pink. The leaves are covered with crystal-like drops, shining brightly in the sun; its foliage is remarkable. Pkt. 10c; $1 / 4$ oz. $20 \mathrm{c}$.

\section{Mignonette (A)}

This popular little flower is well-known as one of our most fragrant plants, and a universal favorite. If sown at intervals in spring and early summer it will bloom until killed by frost. Thrives best in a cool temperature.

Sweet. This is the familiar old large flowering variety. It has spikes of medium size, so fragrant that a bed will perfume the whole atmosphere around it, and every garden should have a corner or bed devoted to it. Pkt. 10c; oz. 25c.

\section{Oxalis (P)}

Splendid little plants, with bright colored flowers, for hanging baskets, rock work, or edgings.

Mixed. Pkt. 10c; 1/8 oz. $40 \mathrm{c}$. 


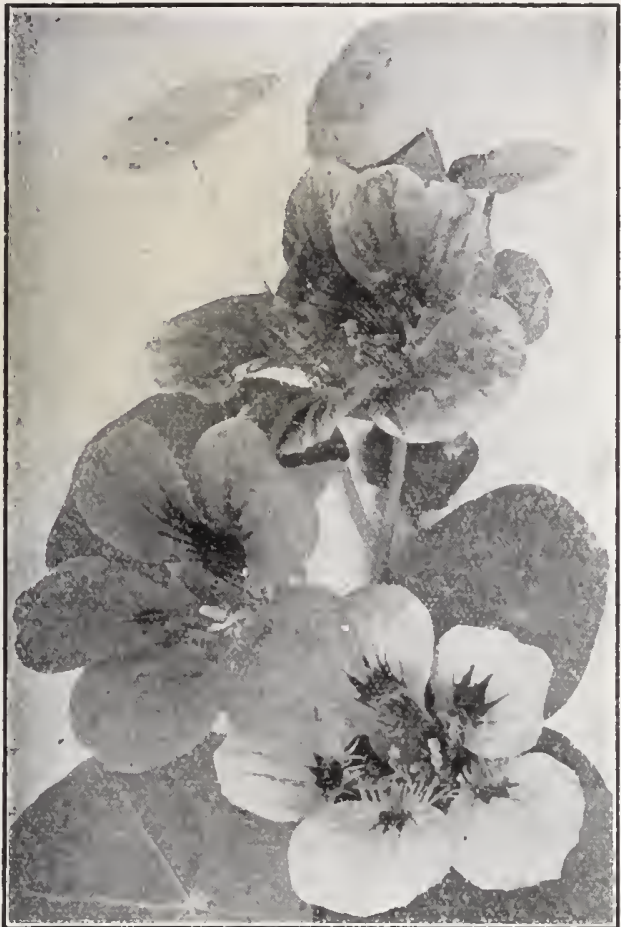

Nasturtium
There is no bedding plant of easier culture than the Petunia, and few that make a gayer appearance when in full bloom. They are easily grown and very popular for bedding. They thrive best in a warm, sunny location. The shape of the flower is similar to that of the Morning Glory.

Single Mixed. Pkt. 10c: 1/2 oz. 50c.

\section{Nasturtium (A)}

Probably the most popular and easily grown flower in our list. and remains longer in bloom. In favorable soil the flowers are produced in abundance during the season. Nasturtiums prefer dry, rather rocky soil, such as we usually call "poor" soil, and bear their flowers in such locations in greater profusion than in a rich garden, where they run too inuch to leaves.

Dwarf Mixed. Th is mixture contains all of the choicest and pretticst flowers of the Dwarf variety. The plants form a small round bush, 12 to 16 inches high which is a mass of blooms all summer. Oz. 10c; $1 / 1$ lb. $30 \mathrm{c}$; lb. $\$ 1.00$, postpaid.

Tall Mixed. This mixture contains all of the choicest and prettiest flowers of the tall variety, are of quick growth, covering a whole hedge or trellis in a short time. The brilliant blossoms almost cover the plant from top to bottom. Oz. 10c; 1/4 lb. 30c; lb. \$1.00, postpaid.

\section{Pansy (P)}

No description is needed of these little favorites and it would be hard to find a garden the charm of which is not in a large measure dependent upon their marvelous coloring.

D. \& B.'s Superb Mixed. This is a mixture of all the giant flowering varieties, all the plain colors, faced sorts, ruffled edged and rare sorts, also the varieties exquisitely striped. The seed is saved from the most

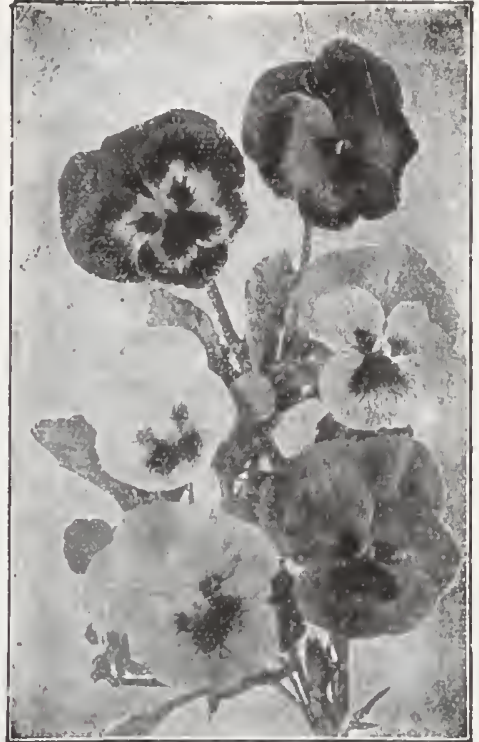

Pansy

\section{Phlox Drummondii (A)}

One of the prettiest and most popular of garden annuals. Makes very attractive beds, and continues to bloom throughout the summer. Sow in April in open ground, or can bo started earlier indoors.

Grandiflora Mixed, Extra Large Flowering. A great improvement on the common type, both heads and florets being nearly twice as large. Pkt. $10 \mathrm{c} ; 1 / 4$ oz. 30c; oz. \$1.00.

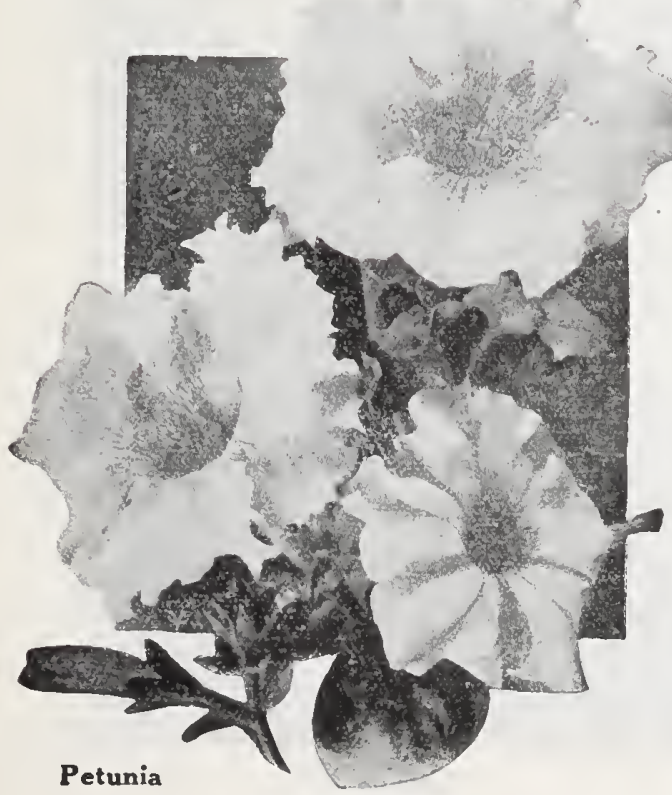
famous pansy gardens, from exhibition flowers. These pansies are wonderfully beautiful in every way and are the very best types. The small difference in the cost of this seed over the other seed is covered one hundred-fold in satisfactory results to the grower. Pkt. 25c ; $1 / \%$ oz. $\$ 1.00$

English Prize Mixed This mixture is of magnificent varieties, containing the so called faced varieties and is in every respect equal to many of the higher priced named Pansies. Pkt. 10c; $1 / 8$ oz. $40 \mathrm{c}$.

Choice Mixed. $\mathrm{T} h$ is seed is saved from very good garden varieties, the flowers are small in comparison with the fine sorts, but the colors are good. Pkt. 10c; 1/4 oz. 40c.

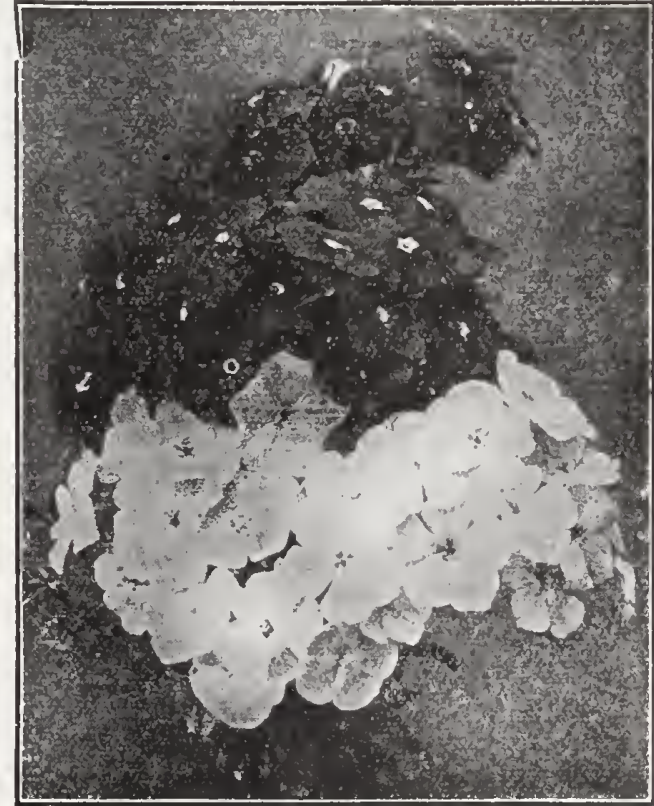

Grandiflora Phlox 


\section{Poppy (A)}

Hardly any class of plants afford the same brilliant colorings and showy display. 'They are of easy culture, the seed being sown where they are to remain. Thin the plants 6 to 12 inches apart.

Shirley. These beautiful Poppies are annuals; are very Iree flowering and of remarkably brilliant colors, from pale rose to deep crimson. Many of the flowers have crimped or wavy petals; all are of fine silky texture, but of good substance, and not surpassed by any for cutting. Finest mixed. Pkt. 10c; oz. 30c.

Orientale. A large gorgeous scarlet blossom; base of petals black. This is a perennial variety and is one of the most striking and showy. Pkt. 10c; $1 / 4$ oz. 50c.

Single Mixed. All the fancy and named single varieties mixed. Pkt. 10c; oz. 25c.

Double Mixed. All the fancy and named double varieties mixed. Pkt. 10c; oz. 30c.

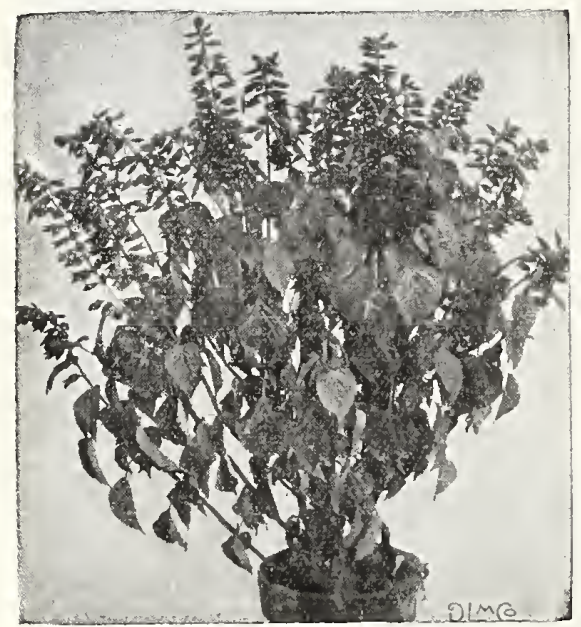

Salvia Splendens-(Scarlet Sage)
Primrose

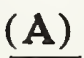

Green-house or pot plants, b e a r i n g trusses of large single or double blossoms in bright colors, as well as soft tints. Sow the seed in A pril or May for winter blooming.

Mixed. The choicest large flowering varieties $\mathrm{m}$ i $\mathrm{x}$ e d. Pkt. 20c.

\section{Portulaca (A)}

A low-growing or creeping tender annual 6 to 8 inches high, and bearing glossy, cup-shaped blossoms in very brilliant and gorgeous colors. The seed germinates slowly and should be started under glass or when the weather is hot. These flowers love the sunshine and do best on rather dry ground.

Double Mixed. Extra large flowering. From 50 to 60 per cent of the flowers will come double. These are especially beautiful and showy. Pkt. 10c; $1 / 4$ oz. 60c.

Single Mixed. This is an extra fine strain with very large blossoms and splendid colors. Pkt. 10c; 1/2 oz. 35c.

\section{Ricinus-Castor Oil Plant (A)}

Luxuriant rapid-growing annuals with palm-like leaves. Brcellent for background or center of beds of foliage plants, the effect being especially striking after the brilliantly colored fruit is formed. Mixed. Pkt. $10 \mathrm{c} ; 0 \mathrm{oz} .15 \mathrm{c} ; 1 / 4 \mathrm{lb} .40 \mathrm{c}$.

\section{Salvia Splendens-Scarlet Sage (A)}

A well-known favorite bedding plant which bears magnificent spikes of scarlet flowers from July to October. Although perennial, it blooms the first year from seed, and there is really no flower that can rival it in brilliant color. Pkt. $10 \mathrm{c} ; 1 / 4$ oz. 50c; oz. $\$ 1.75$.

\section{Scabiosa-Mourning Bride or Sweet Scabious (A)}

Have perfectly double flowers, are useful for cutting and they are gracefully borne upon long tender stems well above the foliage, and makes a beautiful cut-flower; height 2 feet.

Tall Mixed. Pkt. 10c; 1/2 oz. 35c.

\section{Sensitive Plant-Mimosa (A)}

Curious and interesting little plants with pinkish white flowers. The leaves close and droop when touched. Pkt. 10c; $1 / 4$ oz. 25 c.

\section{Smilax (A)}

A charming, delicate and graceful indoor climber, running 6 feet or more and very useful for decorations. A very desirable window vine. Pkt. 10c; $1 / 4$ oz. $25 \mathrm{c}$.

\section{Stocks, Dwarf German-Ten Weeks (A)}

Desirable for bedding or pot culture. They bear an immense quantity of fragrant blooms, each plant forming \& perfect bouquet and are splendid for cutting.

Single Mixed. Pkt. 10c; $1 / 4$ oz. $40 \mathrm{c}$.

\section{Sunflower (A)}

Red Sunflower. A variety growing about 6 feet high with well shaped dark-centered flowers of bright chestnut reddish brown, merging to yellow at the tips of the petals, branches freely. Pkt. 10c; oz. $40 \mathrm{c}$.

Mammoth Russian. The well-known old-fashioned giant Sunflower. Pkt. 5c.

\section{Sweet William (P)}

A beautiful class of hardy free-blooming plants of extreme richness and diversity of colors. Produces a fine effect in beds or mixed flower borders.

Single Mixed. Pkt. 10c; oz. 60c

Double Mixed. Pkt. 10c; oz. 75c.

\section{Verbena (P)}

These well-known flowers are splendid for beds or massing. The flowers are of the most brilliant colors, blooming from early summer till late in the fall. Verbenas grown from seed are always thrifty and do not rust.

Separate colors. Scarlet, Pink, Purple Shades. Each pkt. $10 \mathrm{c} ; 1 / 4$ oz. $40 \mathrm{c}$.

Mammoth Flowered Mixed. Produces blooms of unusual size and most brilliant colors. Pkt. 10c; $1 / 4$ oz. $35 \mathrm{c} ; \mathrm{oz} . \$ 1.00$.

\section{Violets (P)}

Although these flowers do best when grown from cuttings, they grow readily from seed and produce very fragrant blossoms.

Mixed. Pkt. $10 \mathrm{c} ; 1 / 4$ oz. $\$ 1.00$.

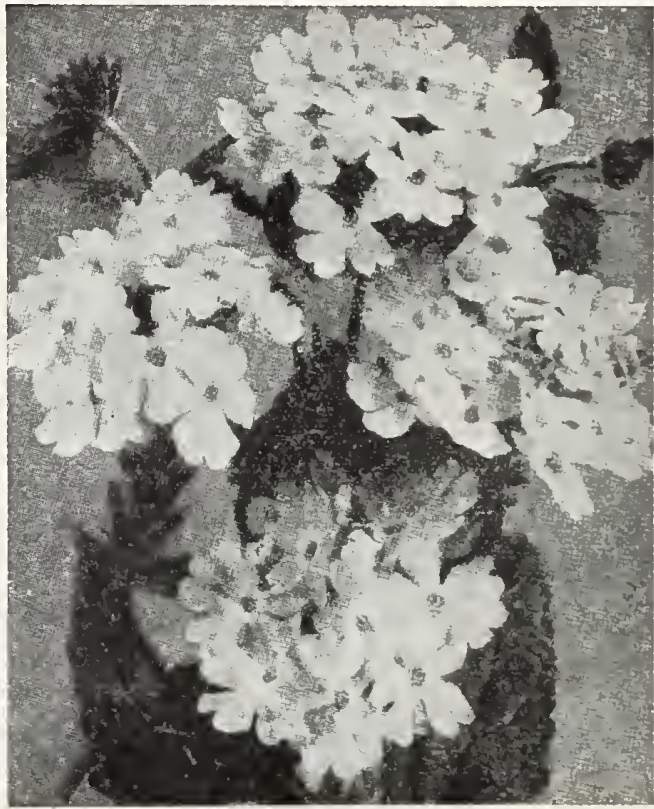

Vorbena 


\section{SW E E T P E A S}

These beautiful and fragrant flowers are becoming more popular each year, and should be grown in every vegetabl and flower garden. They are hardy and easy to grow, andbloom profusely for inany weeks if properly cultivated.

Sow in the spring as early as the ground can be worked, in rows 3 feet apart, and to get the best results they should be staked, as they grow about 4 feet high. For very early blossoms sow in September or October and cover with straw or litter during the winter.

\section{D. \& B.'s Spencer Sweet Peas}

The Spencers are a race or type of sweet peas with extra large flowers, fully double the size of the older forms under good cultivation. The Spencers have very long stems and wavy and fluted-edged petals, which with their rich coloring give an almost orchid-like appearance. The Spencer type will not stand careless cultivation, but if you give them careful cultivation they will fully repay you for the extra trouble by their exceptional size and beauty.

King Edward Spencer. Pure red.

Austin Frederick Spencer. Improved. Large pure lavender.

Apple Blossom Spencer. A beautiful bright Rose Tint of Apple Blossom Pink.

Countess Spencer. Pure pink.

King White Spencer. Beau. tiful white.

Majestic Cream. Large Deep Cream.

Royal Purple Spencer. T h e best purple.

Flora Norton Spencer. Very fine blue.

Othello Spencer. Beautiful deep pure maroon very large.

Above Varieties. Pkt. 10c; oz. $20 \mathrm{c} ; 1 / 4$ lb. $65 \mathrm{c}$; lb. $\$ 2.25$, postpaid.

\section{D. \& B.'s Spencer \\ Mixed Sweet Peas}

This is a splendid, well-blended mixture of all true Spencer types grown separately and then mixed. Pkt. 10c; oz. 20c; $1 / 4$ lb. 60c; lb. $\$ 2.00$, postpaid.

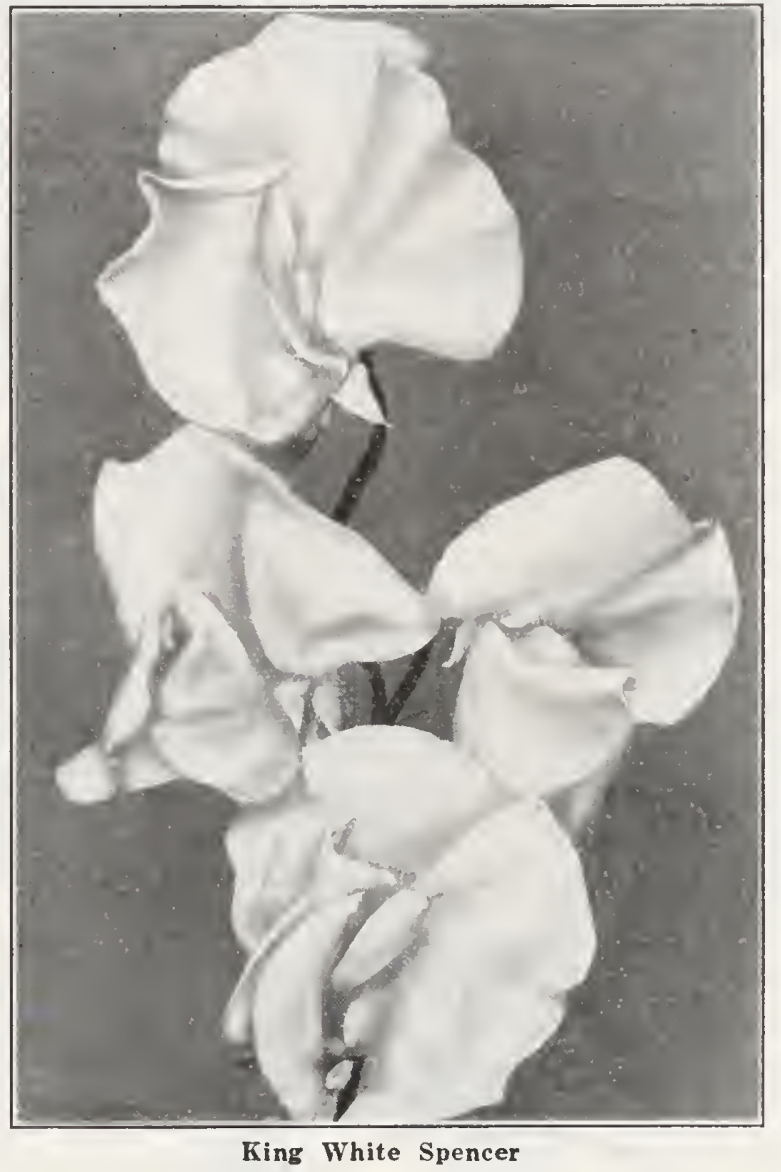

\section{D. \& B.'s Superb Mixed Sweet Peas}

\section{GRANDIFLORA TYPES}

This is the best possible mixture of Grandiflora Types combining carefully considered proportions. It contains all of the finest and large flowering varieties of every shade and color from pure white to dark maroon. Each color is the very choicest of its class, grown separately and mixed by us. While the Spencer Types are more beautiful, this is the finest mixture possibly of Grandiflora Types. $0 z .10 \mathrm{c}$; 1/4 lb. 30c; Ib. $\$ 1.00$, postpaid.

\section{Wallflower (P)}

This is a fine bedding plant but it is more often grown as a pot plant, and for this purpose is well adapted. The flowers are very fragrant and usually of various shades of yellow, brown, and reddish brown. An old-fashioned flower, always popular. Sow early in the year in boxes and transplant.

Single Mixed. Pkt. $10 \mathrm{c}$; oz. $40 \mathrm{c}$.

Double Mixed. Pkt. $10 \mathrm{c}$; $1 / 1$ oz. $\$ 1.00$.

\section{Zinnia (A)}

For gorgeous summer and fall display the Zinnia is unsurpassed, the flowers are perfectly double, resembling Dahlias, and almost every shade of color. For bedding and massing they are particularly suitable.

Grandiflora Mixed. Extra large double flowers, borne un long stems. A general favorite in Zinnias. They flourish luxuriantly in the hottest situations and require very little attention beyond an occasional stirring of the soil. Pkt. 10c; $1 / 4$ oz. 25c; oz. $75 \mathrm{c}$.

STIM-U-PLANT-Plant Stimuplant Tablet-Produces immediate growth in all sorts of flowers and plants. The tablets may be placed at the roots where they dissolve and release their plant food, or can be dissolved in water at the rate of two tablets to each quart. A very convenient method for applying plant food in a concentrated form on potted or house plants. Per package of 30 tablets, 25 c, postpaid.

\section{Flower Garden Mixture}

This mixture is a combination of a great many free-bloom ing, hardy flowers, listed in this catalogue, which can be offered at a much lower price than when sold in separate packages. Those who cannot give the constant care necessary for finely-arranged flower beds will find our Flower Garden Mixture a delightful substitute, with its constant and ever-varying bloom. Such a flower bed is a continual surprise and pleasure, as new varieties and the old garden favorites fluwer successively throughout the season. Thin out where the plants are crowded and keep clean of weeds. Pkt. 10c; oz. 15c; 1/4 lb. 50c.

ALL VARIETIES OF FLOWER SEEDS PRICED AT 10c PER PACKET ARE SOLD FOR CASH WITH ORDER. 3 PKTS. FOR 25c, 7 PKTS. FOR 50c, 15 PKTS. FOR \$1.00, POSTPAID. YOUR SELECTION. 


\section{VINES or CLIMBERS}

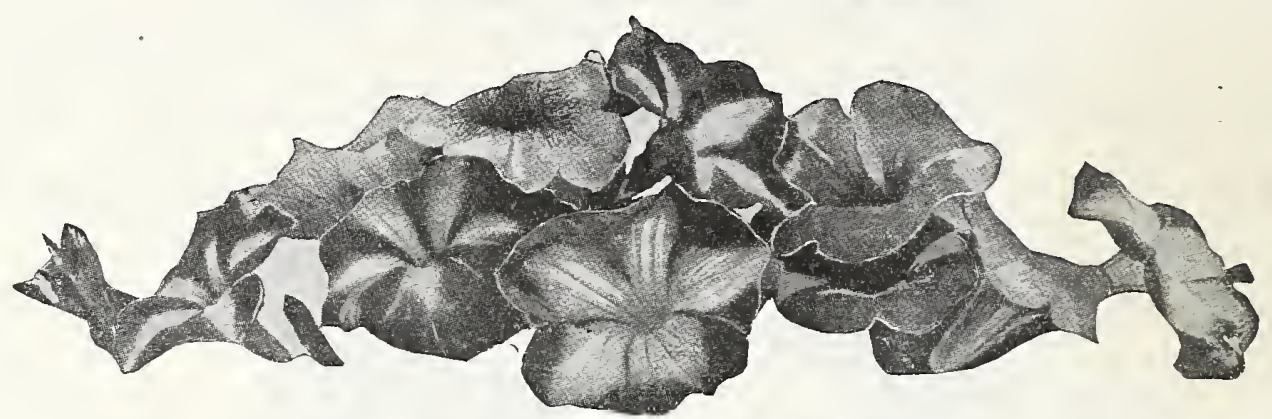

This List Comprises Varieties Which Attain Perfection the First Season. A Few of Them Require Starting in the House, but Most of Them May Be Sown Where They Are to Grow.

\section{Ampelopsis Veitchii-Boston Ivy (P)}

The popular Ivy which covers so many buildings. It clings to brick and wood without support. It is a rapid grower, with beautiful star-shaped foliage of light and dark green, changing with the seasons. Pkt. 10c; oz. 50c.

\section{Balloon Vine-Love-in-a-Puff (A)}

A rapidly-growing climber of attractive foliage, and remarkable for the inflated membranous capsule seed pod from which the name Balloon Vine is derived. This peculiarity also suggests its other name of "Love-in-a-Puff." The flower is white and inconspicuous. Pkt. 10c; oz. 20c.

\section{Balsam Apple (A)}

A very desirable climber, bearing large, prickly, pearshaped yellow fruit, the flesh of which when kept in alcohol make a most effective pain-killer and healer of cuts, bruises, etc. Height 10 feet. Pkt. 10c; oz. 40c.

\section{Balsam Pear (A)}

There is little difference between this and the Balsam Apple, except in the shape of the fruit. Pkt. 10c; oz. 40c.

\section{Clematis (P)}

A beautiful and popular climber for porches, etc. Has many colored flowers. Soak the seed for 24 hours or more before sowing. Mixed. Pkt. 10c; $1 / 4$ oz. 25c.

\section{Cobea Scandens (P)}

one of the best climbers, growing 30 feet or more if planted in a rich sunny situation. Has large foliage with bell ghaped purple flowers. To secure germination, plant the seed in boxes in the house edgewise, covering lightly, and transplant outside in May. Pkt. 10c; $1 / 2$ oz. $25 \mathrm{c}$.

\section{Cypress Vine (A)}

A tender, climbing annual, with soft fern-like foliage and small star-like flowers in red and pink or white which contrast most effectively with the graceful foliage. Height about 15 feet.

Mixed. Plit. 10c; oz. 30c.

\section{Dolichos, Hyacinth or Jack Bean (A)}

A tender, climbing annual. Grows rapidly and is splendid for covering a trellis. Flowers in purple, or white; are borne on long stems, the individual blossoms resembling the bean flower, and the ornamental pods resemble bean pods. Sow seed in open ground late in April. Mixed. Pkt. 10c; oz. 20c.

\section{Gourds (A)}

Climbers of rapid growth, which are well fitted for covering fences, arbors, stumps, etc. The vines are of easy culture and make a rapid growth. The foliage is quite pretty and the fruits are very interesting in their various shapes. Grows from 10 to 20 feet high.

Mixed. Pkt. 10c; oz. 20c.

\section{Kudza Vine-Jack and the Bean Stalk (A)}

A splendid shade vine of wonderful growth, attaining $\mathbf{4 0}$ to 50 feet the second year. Pkt. 10c; $1 / 2$ oz. $40 \mathrm{c}$.

\section{Morning Glory (A)}

Imperial Japanese Morning Glory. These are much the handsomest flowers in Morning Glories, of gigantic size and in colors ranging from snow white to carmine, through every shade of blue and purple to nearly black, also marble, striped and splashed sorts. The vine is not quite so vigorous a climber as the old-fashioned Morning Glory. Pkt, 10c; oz. 20c.

Mixed Morning Glory. No climber is more popular than is the Morning Glory for covering trellises or unsightly back fences. They grow 15 feet high and bear very abundantly brilliant flowers of various colors. Soak the seed for two hours in warm water to hasten the ger-

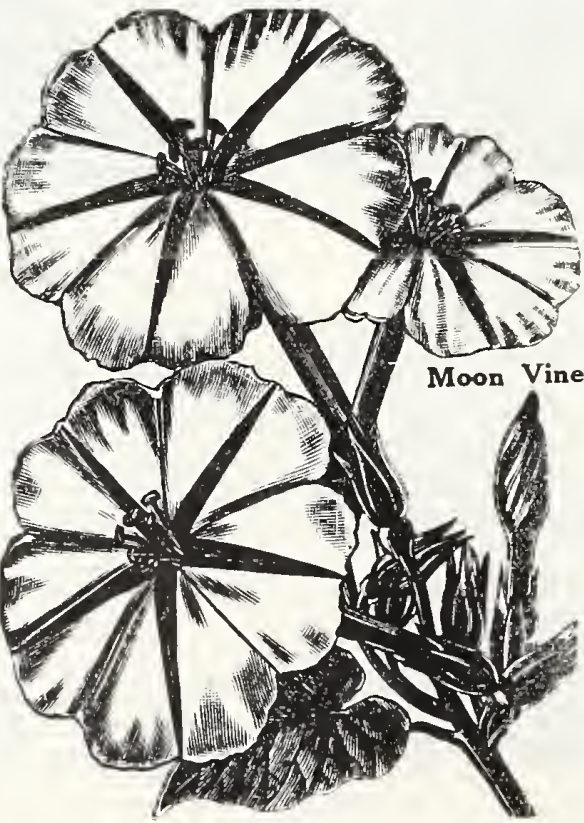
mination. Pkt. 10c; oz. 15c; 1/4 lb. 40c.

\section{Moon Flower or Evening Glory (A)}

Beautiful rapid climbers, bearing large white flowers, 4 to 6 inches in diameter, which open in the evening and on cloudy days. Start the seed in the house and transplant when the weather is warm. Before planting it is best to file a small hole in one end through the outer hull and soak for 36 hours in warm water to hasten germination. Pkt. 10c; 0z, 40c.

Climbers Mixed. A mixture of annual climbing vines. Pkt. 10c; oz. 25c

ALL VARIETIES OF FLOWER SEEDS priced at $10 \mathrm{c}$ per packet are sold for Cash with Order. 3 pkts. for $25 \mathrm{c}, 7$ pkts. for $50 \mathrm{c}$, 15 pkts. for $\$ 1.00$, postpaid. Your selection. 


\section{BEEKEEPING SUPPLIES}

Lewis "Beeware"

Put your bees in up-to-date finely-made Hives and they will pay you big profits.

10-Frame Hive with Metal Roof Cover

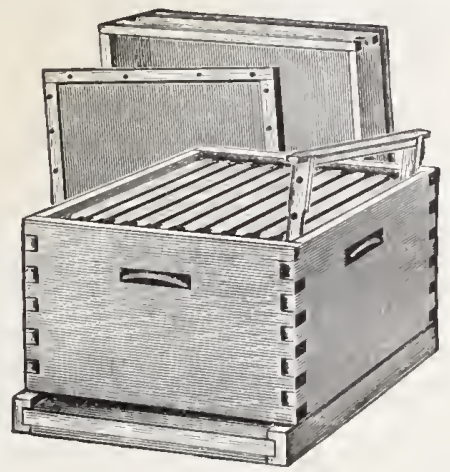

Each

Crate of 5
Weight

$31 \mathrm{lbs}$

$145 \mathrm{lbs}$
Price

$\$ 3.15$

14.15

10-Frame Full Depth Supers or Bodies

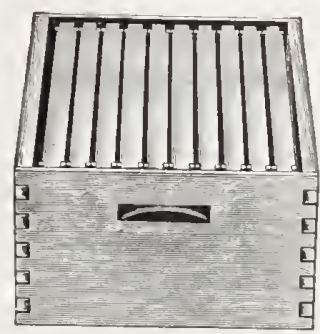

Each

Weight

15 lbs

Price

Crate of 5

$68 \mathrm{lbs}$

A sheet of bee comb foundation must be inserted in every frame of the hive and super. This acts as a guide and causes the bees to build straight combs. It also encourages them to work and supplies them with wax that they would otherwise have to produce. They use about 15 pounds of honey to produce 1 pound of wax.

\section{DADANT'S FAMOUS COMB FOUNDATION}

\section{Wired Medium Brood Foundation For Full Depth Frames}
8 sheets
10 sheets
$\$ 1.10$
50 sheets $\$ 5.10$

\section{Unwired Medium Brood Foundation} For Full Depth Frames
8 sheets
10 sheets
50 sheets
$\$ .72$
$\$ .90$
$\$ 4.25$

Thin Surplus Foundation

For Shallow Frames and Section Boxes

1 lb. box

5 lb. box

$\$ .80$

$\$ 3.75$

28 sheets to the pound; size $37 / 8 \times 161 / 2$ Above size for section boxes.

22 sheets to the pound; size $5 \times 161 /$ Above size for shallow frames.

10-Frame Comb Honey Supers for Scalloped Sections

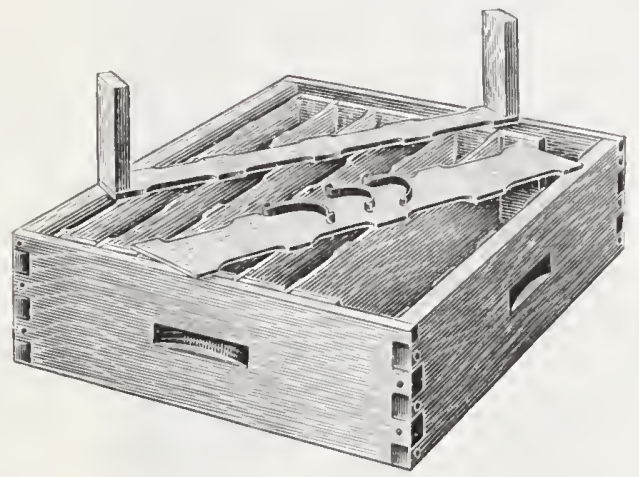

$\begin{array}{lrr} & \text { Weight } & \text { Price } \\ \text { Each } & 9 \mathrm{lbs} & \$ 1.05 \\ \text { Crate of } 5 & 40 \mathrm{lbs} & 4.35\end{array}$

10-Frame Half Depth Supers with Shallow Frames

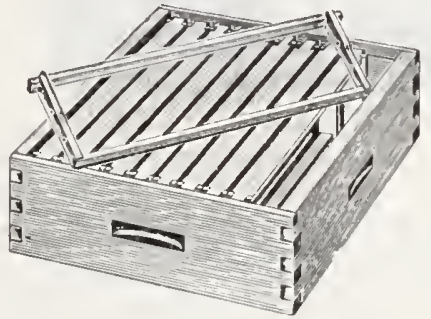

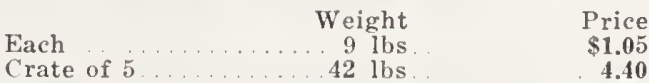

We recommend the above super for beginners. Bees will store surplus honey in the shallow frames much more readily than in the section boxes of a comb honey super.

Lewis "Renown" Honey Sections $41 / 4 \times 17 / 8$ beeway

Per $100 \ldots . \$ 1.30 \quad$ Per $500 \quad \ldots \quad \$ \$ 6.05$

Lewis "Favorite" Honey Sections $41 / 1 \times 178$ beeway

Per $100 \ldots \ldots \ldots 1.20 \quad$ Per $500 \quad \ldots \$ 5.70$

Golden Italian Queen Bees

May 1st to August 1st

Untested Each $\$ 1.00 ;$ Dozen $\$ 10.00$

Tested .......... Each \$2.50; Dozen $\$ 25.00$ Postpaid-Safe arrival guaranteed.

Untested

August 1st to November 1st Each $\$ 1.00$; Dozen $\$ 10.00$

Tested Each \$2.50; Dozen \$25.00

Smoke Engine Smoker $\$ 1.25$ SEND FOR COMPLETE CATALOG 


\section{SUMMER FLOWERING BULBS for SPRING PLANTING}

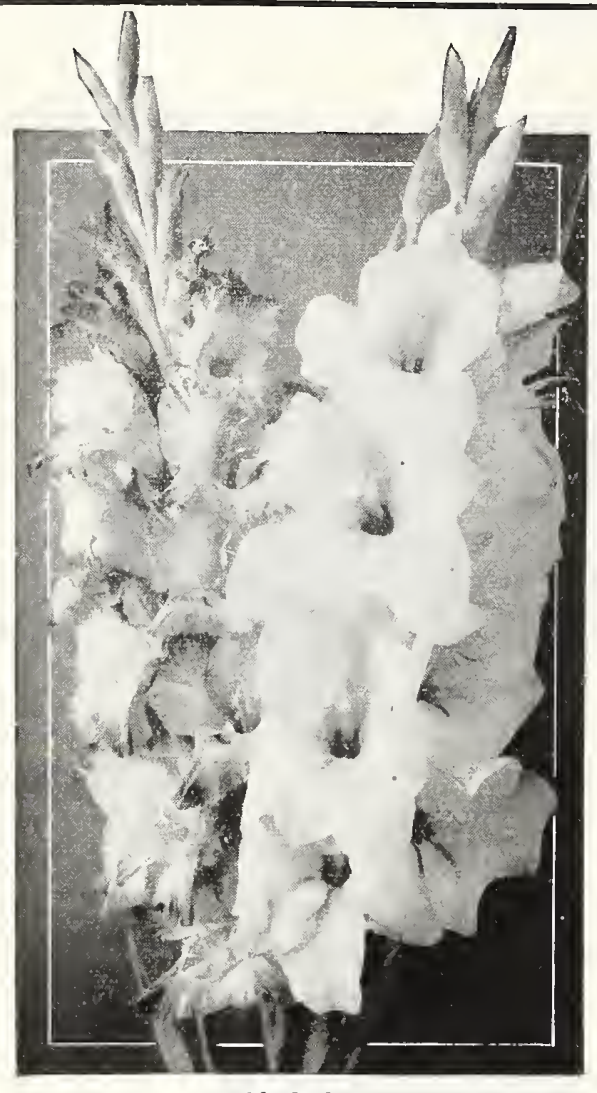

\section{Gladiolus-Finest First Size Bulbs}

These beautiful flowers stay in blossom for a long time and make very attractive cut flowers. They can be planted after danger of frost is past from April to June. Gladiolus have become immensely popular in recent years. They are vigorous plants, are easily grown, and bloom until frost.

America. A beautiful dainty lavender pink; large flowers of waxlike tex. ture. Each 6c; doz. 55c, postpaid. Not postpaid, each 5c; doz. $45 \mathrm{c} ; 100, \$ 2.50$. Mrs. Francis King. A most beautiful vermilion red, large flowers; a magnificent variety. Each 6c; doz. 55c, postpaid. Not postpaid, each $5 c$; doz. 45 ; $100, \$ 2.50$.

Halley. Delicate salmon pink. A most attractive early blooming sort. Each 6e; doz. 55c, postpaid. Not postpaid, each 5c; doz. 45c; 100, \$2.50.

Panama. Extra fine pink. Each 6c; doz. 60c, postpaid. Not postpaid, each 5c; doz. 50c; $100, \$ 3.00$.

Schwaben. Clear canary yellow with small amaranth purple blotch in the center. Has very heavy spikes and foliage. Fine for forcing. Each $\mathbf{6 c}$; dez. 55c, postpaid. Not postpaid, each 5c; doz. 50c; $100, \$ 3.00$.

Peace. Beautiful large white pale lilac feathering. Each 6c; doz. 55c, postpaid. Not postpaid, each 5c; doz. 45c; $100, \$ 2.50$.

Empress of India. Deep purplish red. Each 10c; doz. \$1.00, postpaid. Not postpaid, each $9 \mathrm{c} ;$ doz. $90 \mathrm{c} ; 100, \$ 6.00$.

Marshall Foch. Enormous salmon pink, with little red spot throat. One of the largest flowering Gladioli. Each 7c; doz. 60c, postpaid. Not postpaid, each 6c; doz. 50c; $100, \$ 3.00$.

Mrs. Pendleton. Deep rose pink shading to a pale pink throat. Has large bright rose red blotch on lower petals. Has strong straight spike. Each 6c; doz. 55c, postpaid. Not postpaid, each 5c; doz. 50c; 100, \$2.50.

War. Deep blood red, large flowers. Each 7c; doz. 70c, postpaid. Not postpaid, each $6 \mathrm{c} ;$ doz. $60 \mathrm{c} ; 100, \$ 4.00$.

L'Immaculee. An excellent pure waxy white without a trace of blemish. Many flowers open. Fine for all floral purposes. Each 7c; doz. 70c, post-

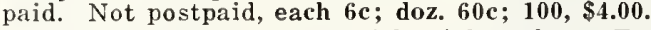

Baron Hulot. A deep rich violet blue. Each 10c; doz. \$1.00, postpaid. Not postpaid, each $6 \mathrm{c} ;$ doz. $60 \mathrm{c} ; 100, \$ 4.00$.

Lovesfire. Bright scarlet, very attractive. Each 11c; doz. $\$ 1.10$, postpaid. Not postpaid, each $10 \mathrm{c} ;$ doz. $\$ 1.00 ; 100, \$ 6.50$.

Mixed Gladioli. A mixture of the above varieties, grown separately and Gladiolus mixed by us. Per doz. 50c, postpaid. Not postpaid, doz. 45c; 100, $\$ 2.50$.

\section{CANNA ROOTS}

We are listing only what we regard as the best and most satisfactory kinds to grow, They are grown especially for us by an expert on Cannas, and we consider each the finest and most satisfactory variety of its kind.

King Humbert. This is claimed by many to be the finest Canna that grows. It has large bronze foliage and flowers of enormous size. The plants are crowned with immense heads of orchid-like, velvety orange-scarlet, rose tinted blossoms margined at the base; a combination of leaf and blossom incomparably beautiful. It is broad and massive. 4 feet. Each $15 \mathrm{c} ;$ doz. $\$ 1.25 ; 100$, $\$ 6.50$, postpaid. Not postpaid, each $10 \mathrm{c} ;$ doz. $\$ 1.00 ; 100, \$ 6.00$.

Robusta. Perhaps the largest Canna grown. Bronze foliage, red blooms, recommended especially for its heavy foliage, but does not bloom freely. Has large, strong, vigorous roots. Height 6 feet. Each 15c; doz. \$1.25; 100, \$7.00, postpaid. Not postpaid, each $10 \mathrm{c} ;$ doz. $\$ 1.00 ; 100, \$ 6.50$.

Eureka. We consider this the best white Canna for all purposes. The large substantial flowers are very freely produced on strong, vigorous plants of green foliage. 4 feet. Each $15 \mathrm{c}$; doz. $\$ 1.25 ; 100, \$ 7.00$, postpaid. Not postpaid, each 10c; doz. $\$ 1.00 ; 100, \$ 6.50$.

Mrs. Alfred F. Conard. The grandest salmon pink Canna in existence. Has magnificent heads of perfectly formed flowers of great size and wonderful substance. Green foliage. 4 feet. Each 18c; doz. \$1.50; 100, \$9.00, postpaid. Not postpaid, each $15 \mathrm{c}$; doz. $\$ 1.30 ; 100, \$ 8.50$.

Prices of the following Varieties of Cannas: Each 10c; doz. $\$ 1.00 ; 100, \$ 6.00$, postpaid. Not postpaid, each $8 \mathrm{c}$; doz. 85c; $100, \$ 5.50$.

Madame Crozy. Flowers brilliant vermilion-scarlet, with narrow edge of bright golden-yellow. Green foliage. $3 \frac{1}{2}$ feet.

Shenandoah. The flowers are salmon-pink, borne in large clusters; the foliage is rich ruby-red. 4 feet.

Richard Wallace. Canary-yellow blossoms. Very productive of flowers. One of the best yellows. Green foliage. 4 feet.

Charles Henderson. This is one of the old favorite varieties. It has green foliage and the flowers are deep crimson-scarlet with flame-yellow throat. Height 4 feet.

Wyoming. A true orchid-flowered variety, with magnificent orange-colored flowers and purple foliage. Height 5 feet.

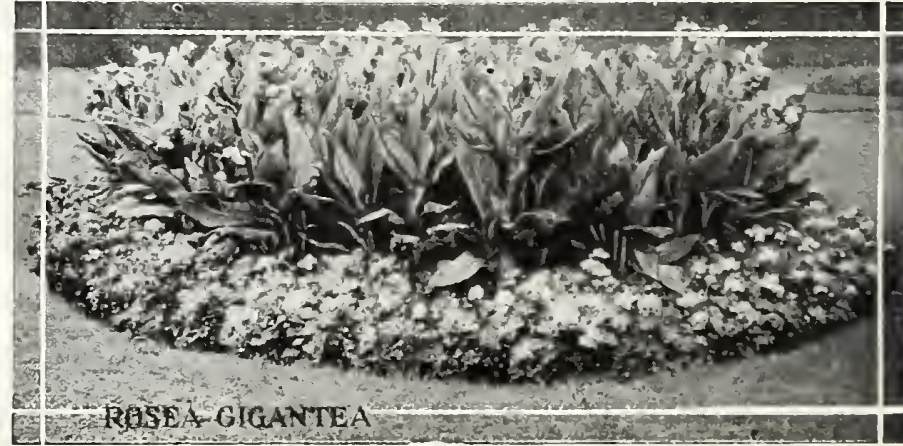

Canna 


\section{Caladium Bulbs-Elephant's Ear}

This is one of the finest and most satisfactory foliage plants grown. A very ornamental plant with immense green leaves. When fully grown they stand 6 to 7 feet high, bearing leaves 2 to $2 \frac{1}{2}$ feet wide.

To get the best results they should be well fertilized with manure and given an abundance of water.

Mammoth Bulbs. 11 to 13 inches in circumfcrence. Each $30 \mathrm{c}$; doz. \$2.75, postpaid. Not postpaid, each 20c; doz. $\$ 2.25$.

Fancy Leaved Caladiums. Beautiful foliage plants for porch, window boxes and shady places, rich and gorgeous yet soft colorings of marvelous beauty. 25c each; 3 for $60 \mathrm{c}$; doz. $\$ 2.25$, postpaid.

\section{Tuberose Bulbs}

Excelsior Pearl. This is decidedly the best and most popular Tuberose. Produces a close spike of fine double flowers, delightfully fragrant, and very popular for bouquets. Plant in rich soil 6 inches apart after danger of frost and give plenty of water.

Mammoth Bulbs. Each 8c; for 25c; doz. 50c, postpaid. Not postpaid, doz. $40 \mathrm{c} ; 100, \$ 3.25$.

\section{Dahlias}

There are few flowers that compare with the Dahlia in charming diversity of form and wide range of brilliant colors, and no other surpasses it for autumn display.

To zrow Dahlias successfully, spade or plow the ground about 12 inches deep in the early snring, and if the soil is poor, work in a liberal supply of manure or a good fertilizer. A sprinkling of Agricultural Lime will also be beneficial. Plant the tuber about 2 inches from the stakes with the eye upward, laying them about 3 feet apart and all pointing the same way in rows 4 feet apart. Plant any time after May 15 th. When the plants are 12 inches high, pinch out the entire top and tie to the stakes. Keep well cultivated at all times. If you desire large blooms disbud them, leaving the center bud and pinch off the other side laterals. Do not water until the buds appear, unless a drought occurs, after that time water freely every seven days. After frost kills the tops dig them and store upside down in a cool, dry place and cover them well with sand.

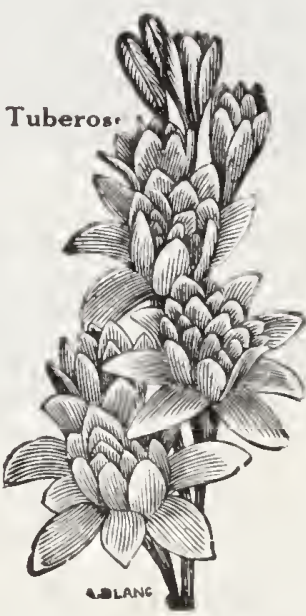

\section{Classification of Dahlias}

Cactus. This class embraces the long, narrow-petaled varieties, the petals of which are generally pointed or twisted.

Decorative. Large flowers, full centers, broad loose petals.

Peony. Have large broad petals, open center.

Show. The old-fashioned Dahlia, has large full head blooms.

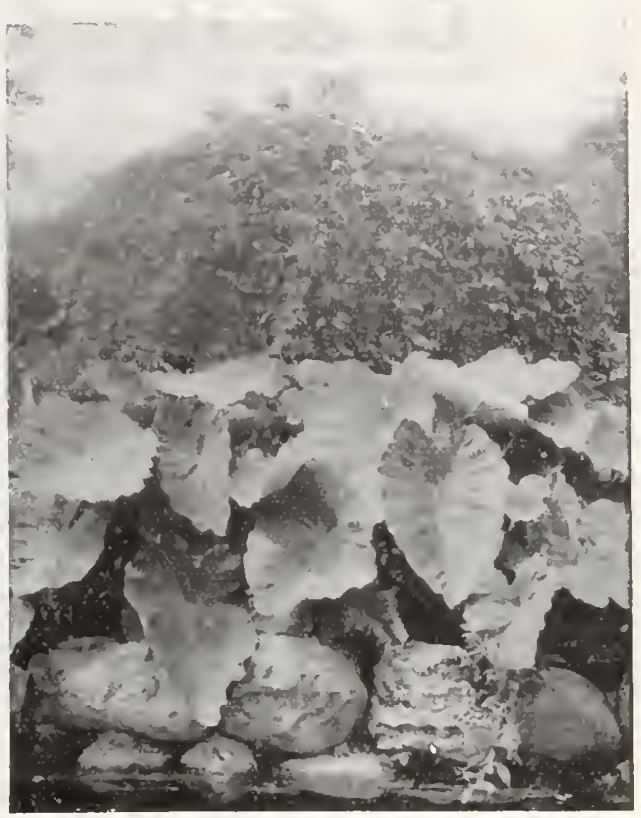

Caladium

\section{Exhibition Dahlias}

Extra Large Mammoth Flowering Varieties.

The following varieties: Each 55c; doz. \$5.50; postpaid. Not postpaid, each $45 \mathrm{c}$; doz. \$5.00.

Mrs. H. W. Struck (Decorative). The largest icy white with extra wide petals.

Jersey Beauty. Pink, large flowers oll fine stems.

Yankee King. Huge Flame Colored Blooms.

Farncott. Light Lavender, 8-inch blooms.

Marmion. Sulphur Yellow, huge blooms.

1. De. Ver. Warner. Deep Lavender, large full petaled flowers.

Sagamore. Beautiful Golden Yellow.

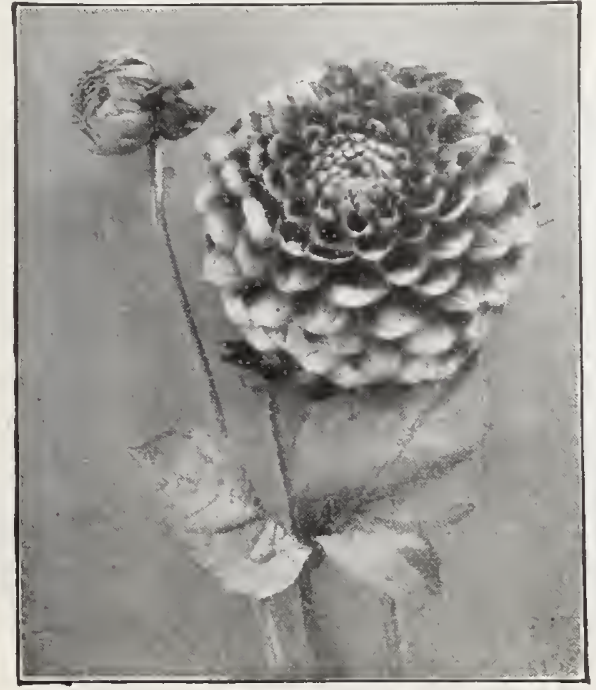

Dahlia

\section{Selected Named Dahlias}

Each 30c; doz. \$3.00, postpaid. Not postpaid, cach 25c; doz. \$2.50.

\section{DECORATIVE}

Pride of California. Beautiful crimon red.

Delighted. Pure white.

Yellow Duke. Yellow.

Mrs. Carl Salback. Rose Pink.

Queen Mary. Light Lavender.

Mina Burgle. Geranium Red.

\section{PEONY}

Oregon Beauty. Oriental Red.

Nina. Pure white.

Dream (Peony Decorative). Peach shaded to Amber.
Avalon. Golden Bronze.

Jane Cowl. Bronze.

A. C. lde. Scarlet.

Queen of Garden Beautiful. Canary Yellow.

Mixed Dahlias - of named varieties - This is a mixture nuade up of named varieties only and contain many excellent kinds. Doz. \$2.00, postpaid. Not postpaid, doz. $\$ 1.75$.

Mixed Dahlias. An exceptionally fine mixture of all types and colors. Doz. $\$ 1.75$, postpaid. Not postpaid, doz. $\$ 1.50$.

\section{BULBS FOR FALL PLANTING}

We issue in September a descriptive list of Hyacinths, Tulips, Narcissus, and other Flowering Bulbs for Autumn planting which blossom in the winter and early spring. If you are a lover of flowers be sure to ask for. it. 


\section{D. \& B.'s GRASS MIXTURES}

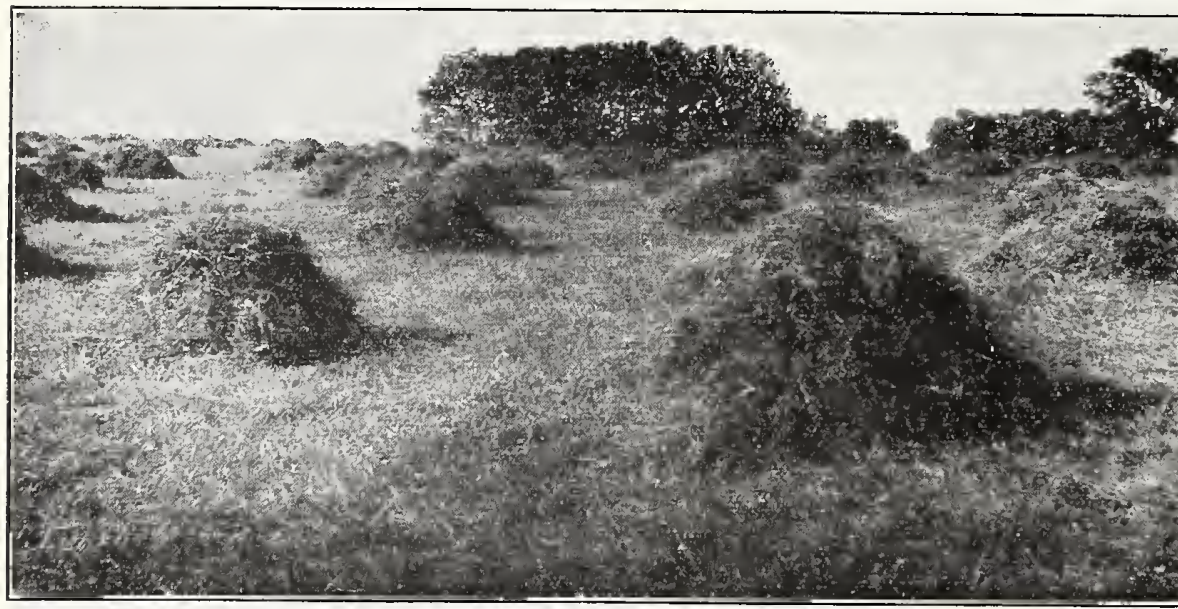

Sow D. \& B.'s Hay Mixtures
It has long been an established fact that Grass Seed when sown in mixture makes a far better yield of hay and also a better pasture than any one variety. We have made careful study of Grass Mixtures, and in offering the following we have the ideal mixtures for the purposes for which they are recommended. Only the highest grade of seed are used and they are thoroughly mixed in the proper proportions to give the best results. In the Hay mixtures we use only the Grasses which have proven the best to sow together and which mature and ripen together, which is of course, necessary to get the best crops. Whilo our pasture mixtures are composed of grasses which mature at different times thereby giving a continuous pasturage. We recommend these mixtures with entire confidence, and we feel sure that they cannot be improved upon, but should any of our customers prefer different mixtures, we will be glad to mix the seeds in any proportion they may wish. Whether you wish to sow a Grass either for a hay crop or grazing, you cannot do better than sow one of these Mixtures

(These Prices are Subject to Market Changes.)

\section{D. \& B.'s Grass Mixture, No. 1, for Hay}

\section{or Pasture}

Recommended for light or loamy upland, for either hay crop or grazing purposes.

Composed of-Orchard Grass, Rye Grass, Tall Meadow Oat

Grass, Red Clover, Alfalfa.

These Grasses mature and ripen together, making a splendid hay. Sow 30 to $35 \mathrm{lbs}$, to the acre. Present price, per lb. $15 \mathrm{c} ; 10 \mathrm{lbs}$. at $131 / 2 \mathrm{c}$ per $1 \mathrm{~b} . ; 100 \mathrm{lbs}$. $\$ 12.50$. Not prepaid. D. \& B.'s Grass Mixture, No. 2, for Pasture

Recommended for light or loamy upland.

Composed of-Orchard Grass, Tall Meadow Oat Grass, Red Clover, Rye Grass, White Dutch Clover, Herd's Grass, Alfalfa, Sweet Clover, Japan Clover, Kentucky Blue Grass.

Sow 30 to $35 \mathrm{lbs}$. to the acre. Present price, per lb. $20 \mathrm{c} ; 10 \mathrm{lbs}$. at $17 \mathrm{c}$ per $1 \mathrm{~b}$; $100 \mathrm{lbs}$. $\$ 15.75$. Not prepaid.

\section{GRASSES}

Timothy This makes an exeellent hay. Is very there is always a good demand for first class ture as it is injured by close cutting or grazing. It thrives best on heavy, moist soils, but does not do well on thin, light, dry land. Sow $15 \mathrm{lbs}$, to the acre. Good crops of hay are obtained when the seed is mixed 7 pounds of Timothy, together with 4 pounds each of Sapling Clover and Herds Grass to the acre, as these three Grasses ripen together. See Current Price List for quotations.

Herd's Grass, or Red Top This excellent pasture and hay grass does well on any soil, but thrives best on moist, heavy soils. It spreads and thickens from year to year, and will gradually upplant other grasses. Matures at the same time as Timothy, with which it makes a good mixture. Sow 10 to 12 lbs, to the acre. See Current Price List for quotations. Timothy hay, but it is not recommended for pas-

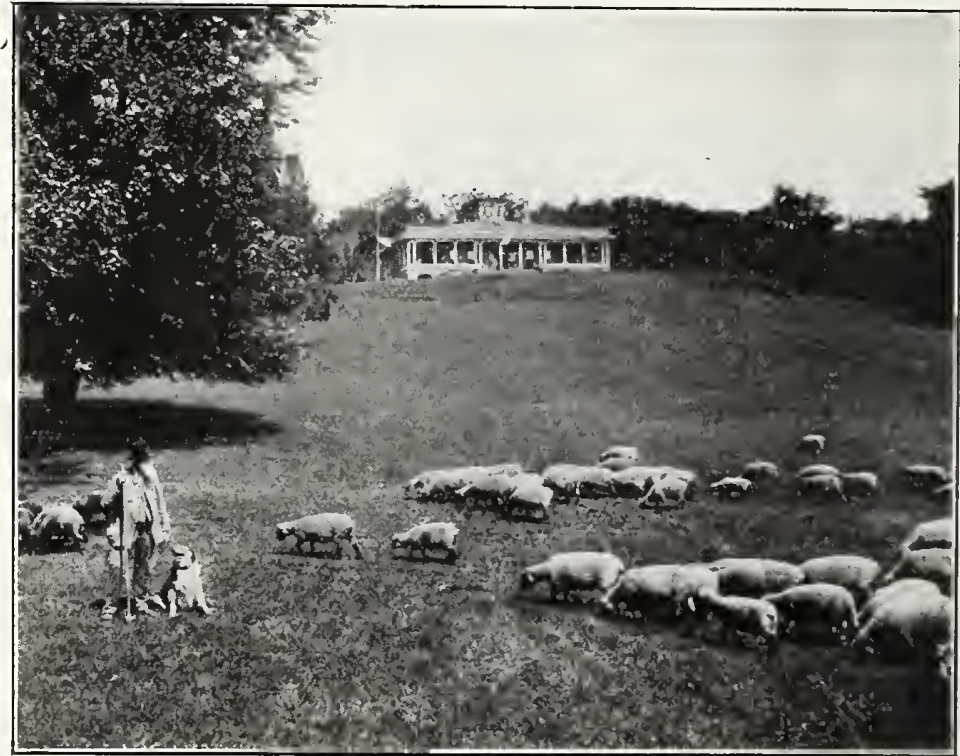

Sow D. \& B.'s Pasture Mixtures
D. \& B.'s VELVET GREEN LAWN GRASS makes beautiful Lawns. See page 1.
Composed of-Kentucky Blue Grass, Alsike Clover, Herd's Grass, White Dutch Clover, Meadow Fescue.

Sow 30 to 35 lbs. to the acre. Present price, per lb. 20c; $10 \mathrm{lbs}$. at $18 \mathrm{c}$ per lb.; $100 \mathrm{lbs}$. \$16.50. Not prepaid.
Recommended for stiff, heavy or low lands.

Composed of-Timothy, Herd's Grass, Mammoth Clover, These Grasses mature and ripen together. Sow 20 lbs. to the acre. Present price, per $1 \mathrm{~b} .17 \mathrm{c} ; 10 \mathrm{lbs}$, at $15 \mathrm{c}$ per $\mathrm{lb}$; 100 lbs. $\$ 13.50$. Not prepaid.

\section{D. \& B.'s Grass Mixture, No. 4, for Pasture}

Recommended for stiff, heavy or low lands. 


\section{GRASSES---Continued}

Orchard Grass This is one of the most reliable grasses for hay or pasture grown in this section, making a quick, or fall, and in any soil; loamy upland is best. It is excellent to mix with other grasses. See Current Price List for quotations.

Tall Meadow Oat Grass A most valuable grass for the South, as it stands heat and drought well and flourishes on Sow 25 lbs, to the acre. See Current Price List for quotations.

Kentucky Blue Grass This grass succeeds best on limestone soils, but does well on any good stiff soil. Stands turf. Used for lawns or pastures. Sow either in the fall ox spring 30 to 35 lbs, to the acre. See Current Price List for quotations.

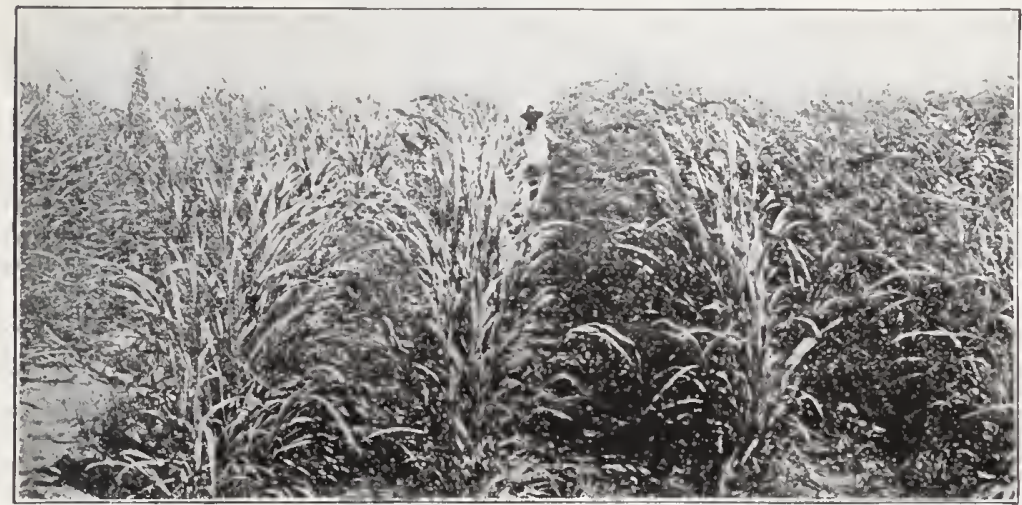

Sudan Grass
Canada Blue Similar to the Kentucky better on thin, light soils where Kentucky Blue Grass does not do so well. Sce Curreat Prico List for quotations.

Meadow Fescue Remains green all nutritious pasture, and also yields well as a hay crop. Largely used for grazing. Sow about 30 lbs. to the acre. See Current Price List for quotations.

Domestic Rye Grass Good for hay sown on strong, moist soil, but does not stand drought well. It grows rapidly and mature very early. Sow 30 lbs, to acre. Sec Current Price List for quotations.

Italian Rye Grass Has large, broad Thrives best on moist, fertile soils, furnishing 2 to 3 cuttings a year. Sow about $35 \mathrm{lbs}$. to the acre. See Current Price List for quotations.

Creeping Bent A very valuable grass for pasture and lawns and is particularly recoinmended for golf links, as it stands trampling perhaps as well or better than any other Grass. Per lb. $\$ 1.10 ; 51$ bs. $\$ 5.00 ; 101 b 8$. $\$ 9.50$, postpaid. Write for price in large quantities.

Red Fescue Used for lawns and golf course mixtures. Per lb. 50c; 5 Ibs. \$2.25, postpaid. Not postpaid, per lb. 40c;

Bermuda Crass A valuable grass for permanent sod, and especially recommended for dams and terraces, as it has which is to be planted in other crops, as it is very tenacious in habit and very hard to eradicate after it once gets a hold; for this reason is used extensively on golf links. It is very similar to our Virginia Wire Grass. Sow in March or April, August and September about $10 \mathrm{lbs}$. to the acre, in well prepared soil. Seeds are slow to germinate. Per $1 \mathrm{~b}$. $35 \mathrm{c} ; 5 \mathrm{lbs}$. \$1.65, postpaid. Not postpaid, lb. 25c; 10 lbs.@23c. Write for price in quantity.

Carpet Grass This is one of the most valuable Grasses for the South. It grows on poor, sandy soils better than BerCarpet Crass muda Grass and it does well on most any soil with a fair amount of moisture. It spreads rapidly, stand. the closest grazing and heavy trampling. For lawns and golf course it will make a heavy sod and the closer it is cut the better it thrives and grows. Sow from early spring to July, $10 \mathrm{lbs}$, to the acre for pasture; 20 lbs. to the acre for lawns, parks, etc. Per lb. 30c; 5 Ibs. \$1.25, postpaid. Not postpaid, per lb. 23c; 10 lbs. \$1.90. Write for prices in quantity.

Sudan Grass This is an annual grass and if seeded in May can be cut twice and with favorable seasons three times a Sudan Grass year, but it can be seeded as late as July and will make one cutting. Grows 6 to 10 feet high, when drilled; or if seeded broadcast, 3 to 5 feet. In appearance, it is similar to the Johnson Grass, but does not root as deeplyas it is an annual it is killed out through the winter, and can never become a pest, as has Johnson Grass in some sections of the South. It is, however, a great drought resisting Grass, and is easily cured, making a good hay crop, and all stock relish and thrive on it. This Grass should not be sown until the ground becomes thoroughly warm, about the first of May. Farmers in the South, who have grown this Grass, are enthusiastic about it, as it yields more hay in a season than any other grass. Sow 5 lbs. to the acre in drills 2 feet apart; or if broadcast, 20 to 25 lbs. to the acre. Per lb. 15c; 5 lbs. 60c, postpaid. Not postpaid, lb. $10 \mathrm{c} ; 10 \mathrm{lbs}$. 60c. Ask for price in quantity.

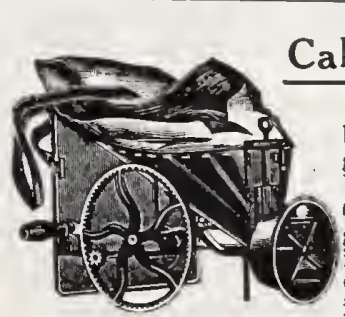

\section{Cahoon Broadcast Seed Sower}

The standard broadcast seeder and the best manufactured. Sows all kinds of grain, Timothy, Clover and heavy seeds. Very simple in operation, and sows 4 to 6 acres an hour at a common walking gait. Distributes the seeds uniformly in one-fifth the time required by hand. Circular on request. Price, \$4.75. Mailing weight $10 \mathrm{lbs}$.

\section{The Cyclone Seed Sower}

This is a splendid little Seeder at a very modest price.

Sows seed evenly; also Fertilizers, Bone or Ashes. Will pay for itself in a few hours. Made of tin and fits the body snugly. Price, \$2.15 postpaid. Not postpaid, \$2.00.

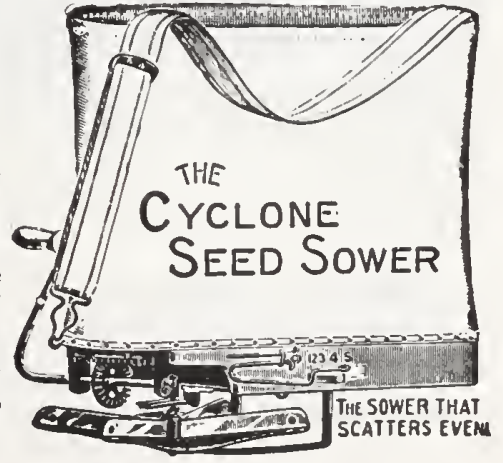




\section{CLOVERS}

As the market prices of all Clovers, Grass and Farm Seeds are constantly fluctuating, we are not quoting prices in this catalogue, but will enclose with each catalogue when mailed, our price list giving current prices of these, and will always be glad to quote firm prices and send our current price list of all Farm Seeds at any time on request.

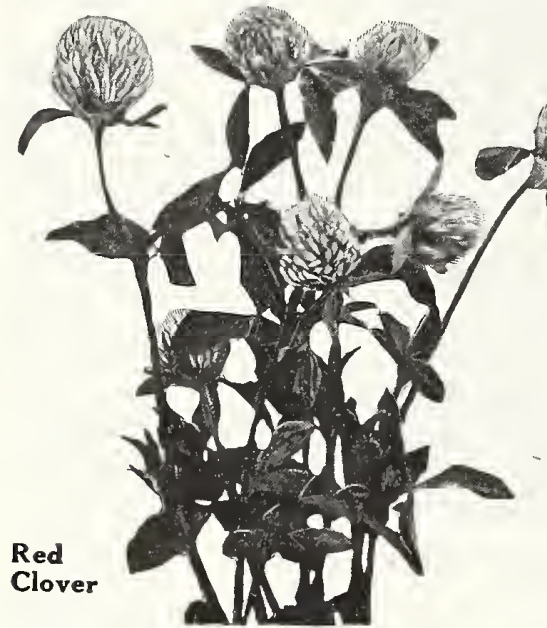

Alfalfa Will produce from 5 to 7 tons of hay to the acre each year, and it can be cut four, and with favorable weather conditions, five times year, and it does not exhaust the soil; its long roots penetrate 15 to 20 feet in the ground, and it therefore successfully resists droughts and gets moisture from this depth during dry spells, whereas any other crop would be a failure. Although fall sowing is preferable, good results can be obtained from spring sowing, if sown in March or early April. It should be seeded on high and rather dry land, as it does not succeed as well on wet grounds. It should be seeded at the rate of about 25 to 30 pounds to the acre broadcast. The soil should be thoroughly prepared and plenty of lime applied, not less than 1,000 lbs. to the acre, and if your land has never had Alfalfa grown on it before be sure to inoculate the seed with Stimugerm (listed on page 61), for without inoculation your success is exceedingly doubtful. Alfalfa is adapted to almost the entire

INOCULATE THIS SEED WITH STIMUGERM otler Hay. Do not risk your crop of Alfalfa by sowing cheap or inferior seed. Our Alfalfa is thoroughly adapted to this section and is the highest grade seed we can obtain, both in purity and germination. See Current Price List for quotations.

Red Clover This is the common Red Clover so popular and well known everyplant. Can be sown in the spring from February 15th to April 1st; also from July 1 st to October 10th, and will be ready for mowing the following spring. Sow 12 to 15 pounds to the acre. We offer only Seed of the highest grade thoroughly adapted to this section. See Current Price List for quotations.

Mammoth, or Sapling Clover Very much like the common Red Clover, later in maturing. Especially recommended for thin soils. Sow 12 to 15 pounds to the acre. See Current Price List for quotations.

Alsike Clover This is probably the best variety to sow with other grasses for very valuable hay. Stands cold well, on either wet or dry soils. Splendid for bees. Alsike is growing more in favor each year as its good qualities become better known. Sow 10 to 12 pounds to the acre. See Current Price List for quotations.

White Dutch Clover Thrives in any soil or climate, and being of low, and lawns; also for bees as it probably makes better and clearer honey than any other blossoms. Sow 6 to 8 pounds to the acre. See Current Price List for quotations.

Sweet Clover or White Bokhara This is a good clover to sow on poor to prevent washing. It is very hardy and stands heat and drought remarkably well. It makes good grazing while young and also makes good quality hay if cut before it blooms, but if allowed to grow tall or blossom it gets hard and woody. Is a good crop to sow to inoculate soil to be followed with alfalfa; is also valuable for bees; we recommend this Clover for poor soil. Sow about 15 pounds to the acre. See Current Price List for quotations.

Crimson, or Annual Clover Makes excellent green forage or if cut when valuable for improving the soil, making a quick, heavy and very valuable crop for soiling. May be sown to advantage in corn, cotton and tobacco at the last cultivation, and will afford a dense mat for plowing under in the spring. Crimson Clover fallowed under makes an excellent preparation for corn, as it keeps the soil in a mellow condition and helps to hold moisture. Sow 25 to 30 pounds to the acre from July to November. Quotations on request.

Korean Lespedeza This variety is considered superior to the ordinary Lorean Lapan Clover as it is better adapted to high alti-

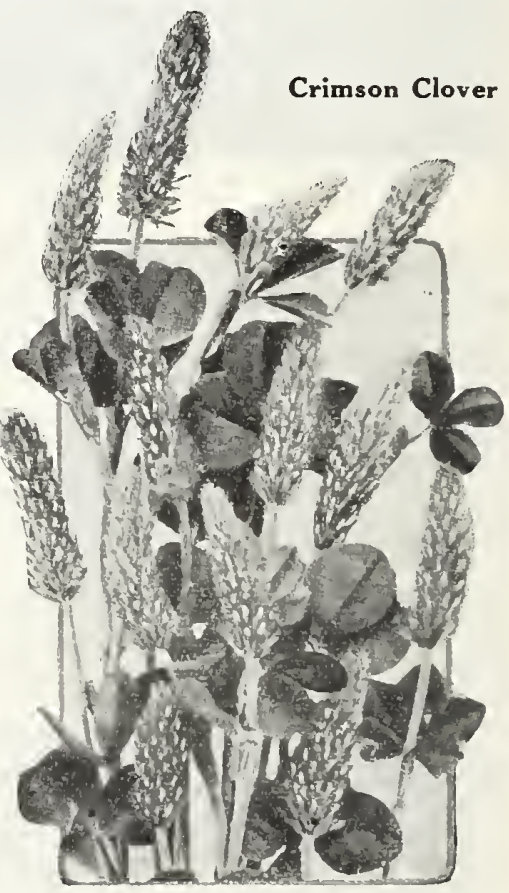
tudes. Starts earlier in the Spring, grows more rapidly, has larger foliage and is
ready to graze before the ordinary variety. It roots deeply, is highly drought resistant and thrives well on acid soils and thin land. See Current Price List for quotations.

Japan Clover, or Lespedeza This is valuable to sow on poor worn-out fields, hillsides, thin woods, groves and a wet bottom lands for summer pasture and for improving the land. It does not produce enough hay in this section to make it of much value for this purpose, but it is particularly valuable for late summer grazing on land that cannot be used for other purposes. Sow 15 to 20 pounds per acre broadcast in March or April and do not graze it early if you wish it to re-seed. While the plants winter-kill, it re-seeds itself and thickens every year and will oon spread. See Current Price List for quotations.

STIM-U-GERM IT PAYS TO INOCULATE your Alfalfa and Clover Crops with Stim-U-Germ. It makes quicker growth, earlier maturity, increases the yield, gathers nitrogen into the soil and improves the land and is a big saver in fertilizer expense. Stim-U-Germ produces a wealth of nodules on the roots. In ordering always state the kind of seed to be inoculated as each kind of Clover requires a different culture. Prices, for small seeded legumes, Alfalfa and all Clovers, $1 / 4$ bu. size, 35c; $1 / 2$ bu. size, 60c; 1 bu. size $\$ 1.00 ; 21 / 2$ bu. size, $\$ 2.25 ; 10$ bu. size, $\$ 8.00$, postpaid. For prices of other cultures see page 61 . 


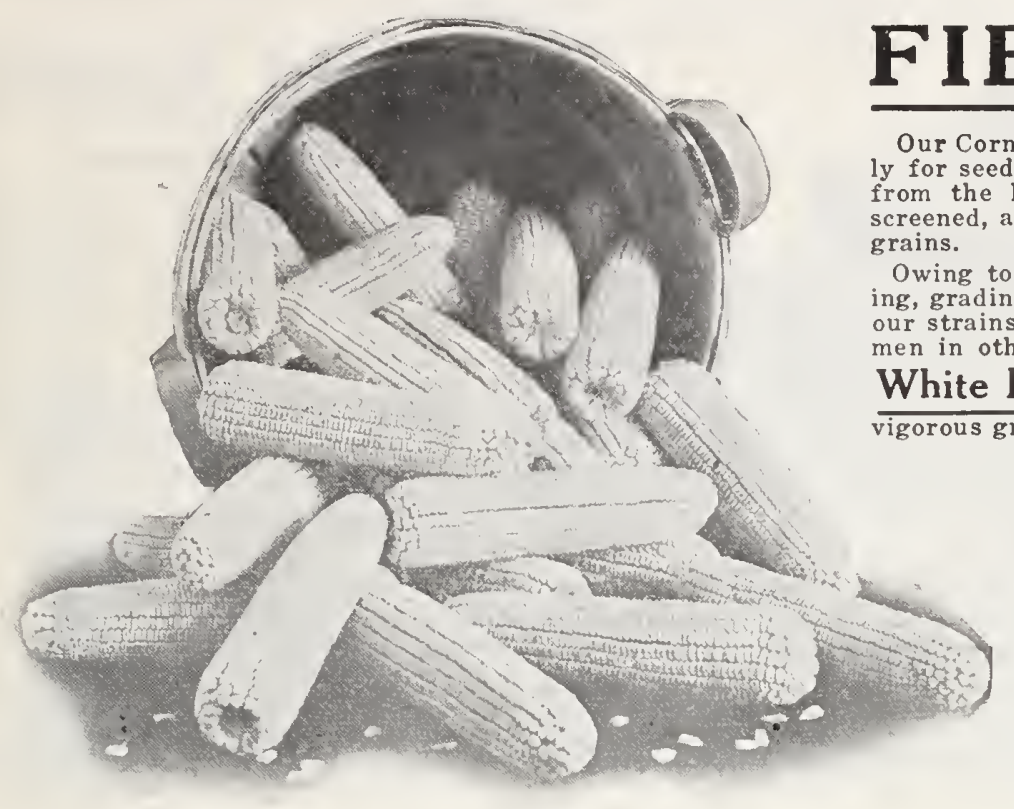

White Dent grains.

Our Corns are grown in Virginia, under contract especialfor seed purposes. The seed is selected and saved only the largest and best ears. It is carefully graded,

Owing to the great care we exercise in growing, selecting, grading and shelling our Corns and the superiority of strains, we sell this in large quantities to many seeds-

White Dent This is the standard White Dent Corn grown in Virginia. It is a hardy and wer, uniform in size and unusually productive. It has pure white grains, large ears with medium size cob, well filled out at both ends. When grown on good land often produces 2 good size ears to the stalk.

Boone County White A large eared White Corn. Has deep, soft and very white grains; a vigorous grower and has taken more premiums for large yield than any other variety. Being a soft corn it is excellent for stock feeding, but is more likely to rot on the stalks in a wet season than harder varieties. Our seed is grown from premium stock.

Eureka Ensilage This is, no doubt, the rown. It yields more forag kind, grows 12 to 15 feet high, has large stalks and an abundance of fodder. The ears are long and slender. Has thick, hard grains and makes good meal. It should be grown only on good land. Is especially adapted to growing on rich low grounds.

Thompson's Prolific This is a moderately early, pure to the stalk shoots low to the prolific Corn, average 2 ears has a prettily shaped ear of medium size, grains are a good size and somewhat harder than the Dent variety, and makes excellent meal. We especially recommend it as the best prolific corn for medium land.

Hickory King An early low growing corn which can be It has a very small cob with large broad grains. Especially recommended for high, light land. Will yield more shelled corn per barrel of cob corn than any other kind. Is said to make better meal than any other variety.

Virginia Ensilage A large White Corn with abundance of ensilage and fodder; also makes good yield of corn.

D. \& B.'s Improved Golden Dent ${ }_{\text {the }}^{\text {We }}$ consider this Corn for this section. It is a hardy, healthy, vigorous growing Corn, and a good ensilage variety. It has large, broad grains of a rich golden color. It is not a flint variety, but it is a moderately hard corn, and does not rot in the field during continued rainy weather, as many varieties do. Matures in about 100 days.

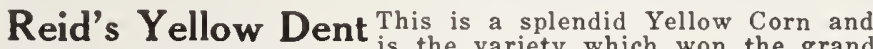
prize at the National Corn Show over all other Yellow Corns. It has also won many other first prizes. It is a big yielder on good loam or heavy land, making ears 8 to 10 inches long, 18 to 24 rows on the ear, has small red cob, the web-shaped grains growing very close together. Very popular in the middle west and southern states. Matures in about 100 days.

Standard Weight, 56 lbs. per bu.

White Dent

Boone County White

Eureka Ensilage

Thompson's Prolific

Hickory King

Virginia Ensilage

D. \& B.'s Improved Golden Dent

Reid's Yellow Dent

Tennessee Red Cob

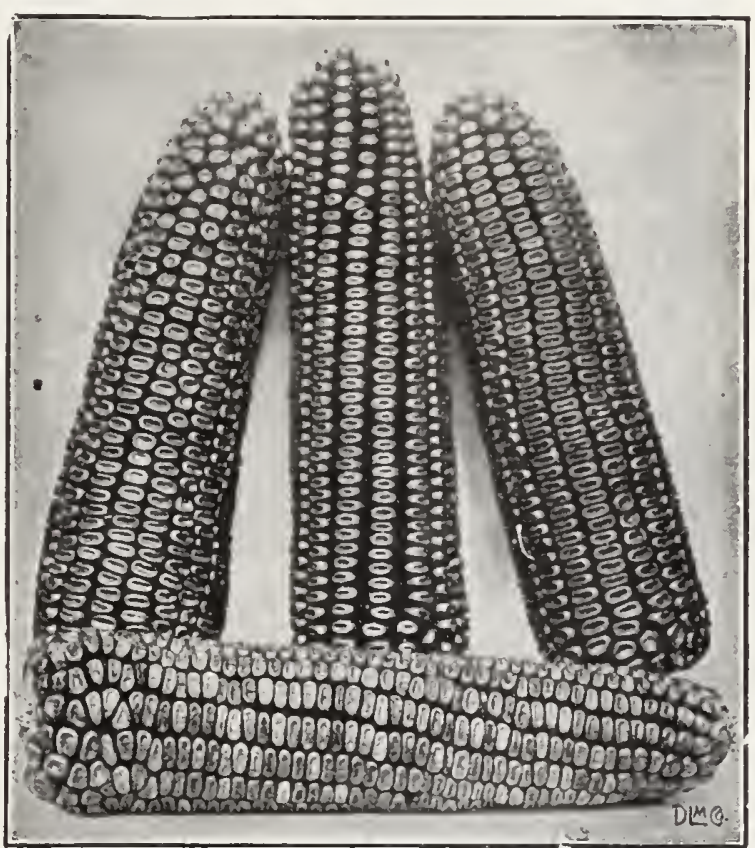

D. \& B.'s Improved Golden Dent

\begin{tabular}{cccr}
\multicolumn{2}{c}{ PRICES } & SUBJECT & TO CHANGE-Per \\
$2 \mathrm{lbs}$. & $10 \mathrm{lbs}$. & Peck & Bushel. \\
$\$ .20$ & $\$ .50$ & $\$ .50$ & $\$ 1.60$ \\
.20 & .50 & .60 & 1.75 \\
.20 & .50 & .60 & 1.75 \\
.20 & .50 & .60 & 1.75 \\
.20 & .50 & .60 & 1.75 \\
.20 & .50 & .60 & 1.75 \\
.20 & .50 & .50 & 1.60 \\
.20 & .50 & .60 & 1.75 \\
.20 & .50 & .60 & 1.75
\end{tabular}

Postage extra if mailed. $10.1 \mathrm{bs}$. is nearly 6 quarts. 


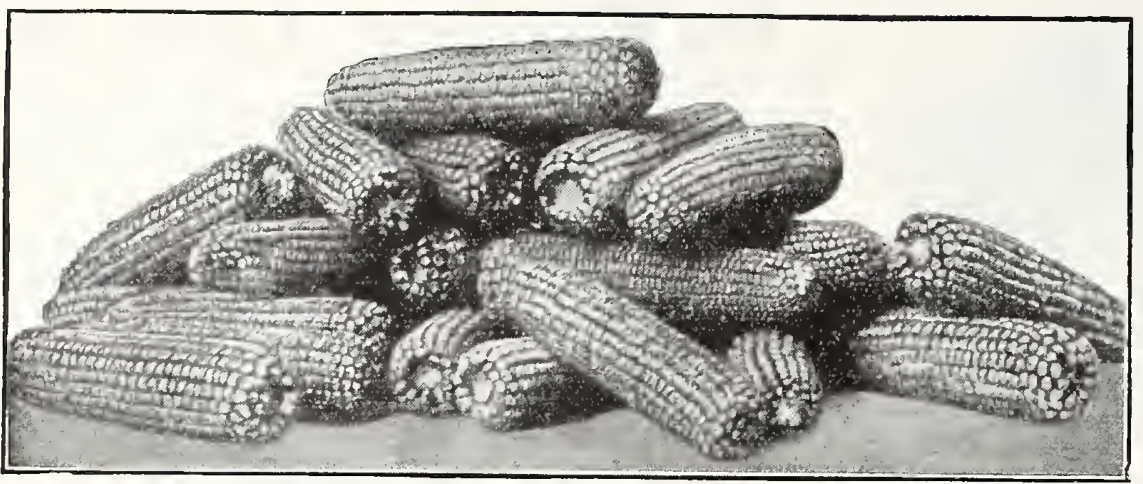

Eureka Ensilage

\section{Field Corns -.-Continued}

Tennessee Red Cob A large Corn with very large deep gourd seed grains. While the grains are pure white the cob is red and rather small. It will produce more bush. els of shelled Corn per measured bushel of Corn on the cob than any variety, except the Hickory King. It is a large yielding variety and makes a splendid ensilage and fodder Corn.

See preceding page for prices.

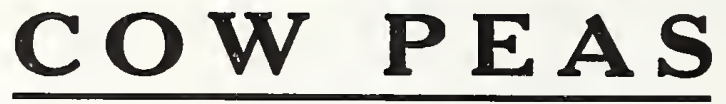

This is one of the best crops that can be grown for enriching the soil; even if the entire crop of vines are cut off and removed, the roots, by their ability to add nutritious qualities to the soil, improve the poorest land and enrich the richest. It is also a splendid forage and field crop, producing a heavy growth of excellent feed. All of our Cow Peas are z'ecleaned and put up in even weight good sacks. The hulls, sticks, cracked and broken peas are taken out, and they should not be compared with peas so frequently offered just as they come from the farmer's hands, which are rarely ever recleaned and generally in very inferior sacks.

Prices of Cow Peas are unsettled at the time this catalog goes to press. Write us for prices when ready to buy.

Black This is the popular variety for forage and for turning under. Very prolific, quick grower, rich and nutritious. On account of its nutrition and yield of peas, is probably the best variety to sow for hogs and for improving the land. Brown Whippoorwill Early, brown speckled peas, one of the most popular varieties; does not have long trailing vines and is therefore easier to harvest for hay. Holds its leaves well.

Taylor, or Large Grey Whippoorwill A large speckled pea with long pods, and makes a heavy yield of shelled

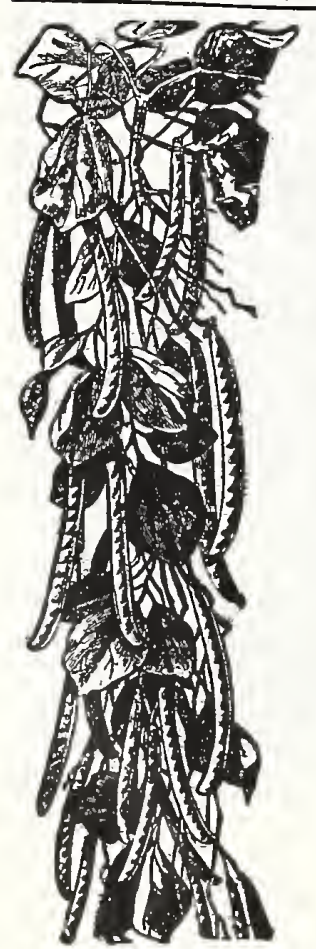

Cow Pees

Clay This is a late running variety. Makes a heavy growth of vine and is therefore more genClay erally used and recommended for plowing under.

Mixed Cow Peas We offer a choice mixture of the principal varieties, which produce a to hold the running varieties off the ground. For this reason there are many more mixed peas used than any one variety.

Cow Peas Mixed With Soja Beans As so many of our customers prefer to sow Cow thoroughly mixed in the proper proportions to give the best results for hay crop. When these are sowed together the crop cures up more readily and the combination makes more hay and hay of better quality than either Peas or Beans when grown separately, and the stiff stalks of the Beans hold the Peas well up off the ground so that the crop can be cut and harvested to better advantage.

\section{Black Eye Peas}

Extra Early Blackeye The earliest of all Blackeye Peas. They grow to a uniform height planting. Because of their extreme earliness, they are very popular with both market and home gardeners for first early use. Tender, sweet and appetizing. Per lb. 25c; 2 lbs. 45c; 51 bs. $\$ 1.00$; 10 lbs. $\$ 1.75$, postpaid. Not postpaid, lb. 20c;2 lbs. 35c; 10 lbs. 95c.

D. \& B.'s Jumbo This is the largest Black Eye Pea known. They yield well and on Per 1b. 15c; 2 lbs. 25c;5 lbs. 55c; 10 lbs. $\$ 1.00$, postpaid. Not postpaid, lb. 10c; 2 lbs. $15 c ;$ peck, $\$ 1.00$. Ram's Horn A large second early Blackeye Pea, used as a table pea both green and dry. 2 lbs. 15c; peck, Per lb. 20c; 2 lbs. 30c; 5 lbs. 50c; 10 lbs. 80c, postpaid. Not postpaid, lb. 10c;

Virginia Black Eye The well-known standard variety; good for table purposes, either Virginia Black Eye green or dry. Per lb. 15c; 2 lbs. 25c; 5 lbs. 45c; 10 lbs. 85c, postpaid. Not postpaid, lb. 10c; 2 lbs. 15c; peck 70c.

\section{Canada Field Peas}

This variety is of the English pea family. Has small seed and pods, grows 4 to 5 feet high, and makes excellent early hay; also makes splendid hog feed and early fallow. For best results we recommend sowing Oats with these in February or March at the rate of one bushel peas and one bushel oats to the acre, which combination makes a splendid hay crop. They also do well when sown in November with either wheat, rye, oats, or barley. We recommend the American grown peas as being far preferable to the cheaper imported peas. Our stock is the best American grown. See current prie list for quotations. 


\section{Soy or Soja Beans}

Soy Beans make a splendid forage crop; they are very nutritious and make a heavy growth of vine. They make a good ensilage and withstand drought better than most forage crops. They make excellent hog feed and a splendid yield of Beans. They are adapted to growing on almost all kinds of soils and are being more generally grown each year.

There are a number of varieties of Soy Beans, many of which are of no special value for growing in this section, but we list a few of the best varieties most suitable for growing in this section.

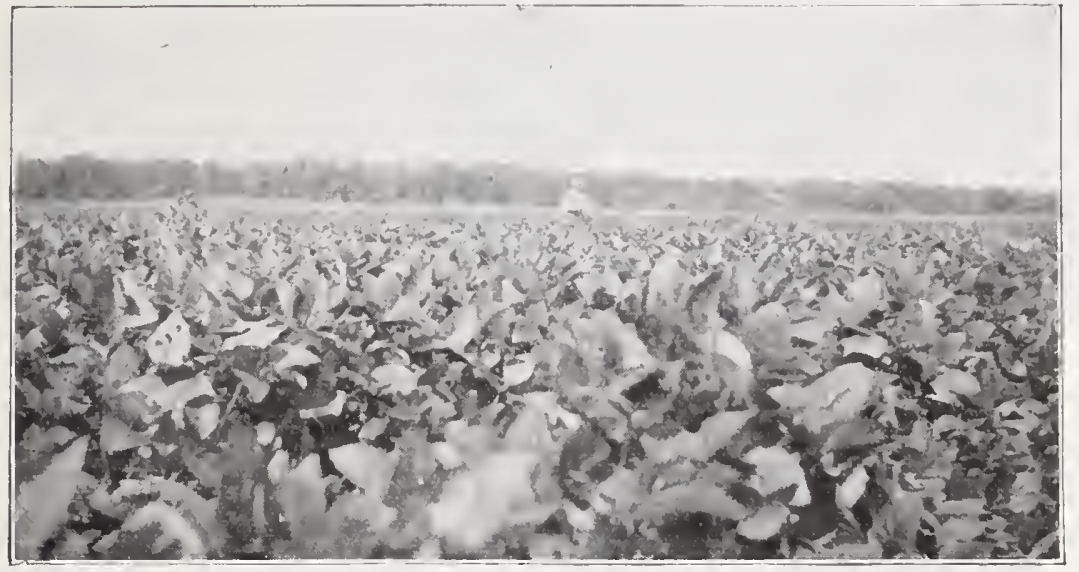

Virginia While this variety is parSouth, on account of its earliness it is also a favorite variety for growing in the Norih and West, where the growing seasons are much shorter. It makes an excellent yield of hay as well as a largo crop of Beans, and its profuse leafage and fine stems and stalks make a hay considered by many as good as Alfalfa, all of which is consumed by the stock. See Current Price List for quotations.

Laredo ${ }^{A}$ variety that has proven to Hay on account of its slender vines and abundant foliage. Is somewhat like the Virginia variety in growth but grows larger and is two or three weeks later in maturing. Has small black seed and requires only about 15 pounds to plant an acre if seeded in rows, or 45 pounds if seeded broadcast. See Current Price List for quotations.

Soy or Soja Beans

Pine Dell Perfection A strong, vigorous and rapid growing Bean. Very healthy and disease resistant. Makes sturdy has heavy foliage and holds growth, supporting itself well, grows from 3 to $3 \frac{1 / 2}{2}$ feet high. Exceptionally adapted for hay, has from this cause even if left standing until Iate in the season. The Agricultural Experimental Stations at Blacksburg and Williamsburg, Va., also the United States Experimental Station at Arlington, Va., and customers who have grown these beans recommend them highly. Sow 3 pecks to 1 bushel to the acre. See current price list for quotations.

Mammoth Yellow One of the largest growing Beans and the most popular variety to grow where the seasons are variety, also yields heavily long enough for them to mature. They will make more tons of hay per acre than any other

\section{VELVET BEANS}

100-Day Speckled A very rapid growing bean; makes larger growth than any other peas or beans known. Especially recommended for improving poor, worn-out lands. Can be sown broadcast, but we think it best to plant in drills and cultivate them once. After they get started they soon cover the ground with vines so dense that it is difficult to plow them under. We recommend turning stock on them, and let them eat and trample down the vines, which can then be turned under or left until spring. Should be planted in May or June, 15 to 30 pounds to the acre, in drills; or 60 pounds broadcast.

In the South they are also largely planted in the Corn. After the Corn is well up and started off growing, 2 Beans are dropped between the hills. The Beans are very vigorous and make a strong quick growth from the start and produce a most luxuriant growth of vine. After the Corn crop is harvested the Beans are left on the land or turned under, which greatly improves the soil or stock may be turned in to feed on them, as stock thrive and fatten on them quickly. In the South these Beans are considered one of the greatest land improvers yet known. The Beans are also valuable for grinding for stock feeding. See Current Price List for quotations.

\section{O A T S}

Burt, or 90-Day The most popular Oat for spring sowing, as it is the earliest grain and feed than most other kinds. On account of its earliness it is more satisfactory to grow than any other spring oat. While it is called a 90-day oat, we have known crops to mature in much less time. Sow 2 bushels to acre. See Current Price List for quotations.

Gray Winter, or Turf This has long been a popular variety in this State for Fall sown early in the spring by March 15th. Sow 2 bushels to the acre. See Current Price List for quotations. Fulghum This oat is of rust-proof type and is a heavy yielder of grain. Is largely rent Price List for quotations.

White Spring A well-known large, heavy White Oat for spring seeding.

Sow 2

\section{SEED WHEAT, RYE, OATS, AND BARLEY}

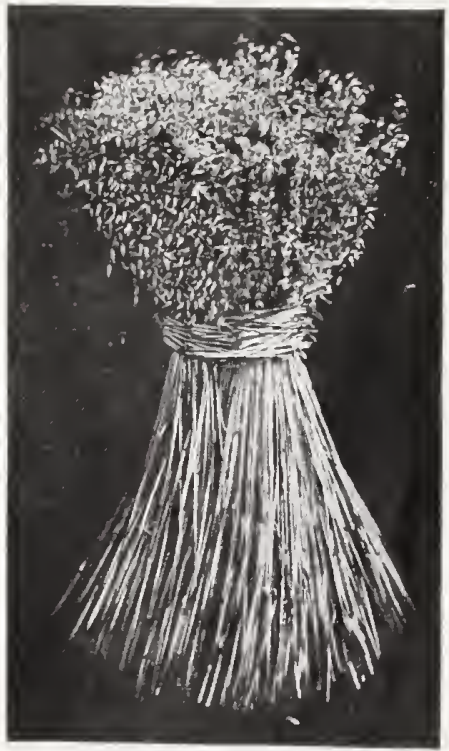

We will have at seeding time in the fall the leading varieties of Seed Wheats, Rye, Oats, and Barley, and will be glad to quote current prices in season on request.

Burt Oats 


\section{MISCELLANEOUS FARM SEEDS}

\section{German or Golden Millet}

\section{Tennessee Grown}

The Tennessee cultivated Millet is considered far superior to German Millet grown in any other section, as it makes a larger growth and has larger heads and produces a crop of much better quality. Millet makes a good yield of feed, provided it is grown only on good land. It should not be grown good poor thin soils. Sow broadcast from May to July, 50 pounds to the acre. See Current Price List.

Pearl, or Cat-Tail Some times cilaria, or Billion-Dollar Grass; this variety gives an enormous yield of very valuable forage. The plants grow about 12 feet high, but it may be cut at 3 feet, when it will thicken up, and may then be cut continuously until frost, giving abundant supply of rich green food. It is also valuable when used as a dry hay. It is usually sown in drills at the rate of about 5 lbs. to the acre, or if broadcast, about $25 \mathrm{lbs}$. Pkt. 10c; lb. 25c; 5 lbs. 90c; 10 lbs. \$1.55, postpaid. Not postpaid, lb. 16 c; 10 lbs. $\$ 1.20$. For larger quantities see Current Price List.

Thousand Headed Kale A large, tall growing variety usually divided into a large number of branches, each producing a great number of large smooth, green leaves which may be cut, or when broken from the stems when full grown will be replaced with new ones. It makes an abundant growth of green feed and is grown for stock and poultry feeding, hardy and prolific. Sow 6 pounds to the acre broadcast; or if drilled in rows, 3 pounds. Oz. 10c;1/4 lb. 20c; lb. 60c, postpaid.

\section{Japanese Buckwheat $\mathrm{T}$ h is}

profitable crop for making grain, also food for bees, soil enricher, or to kill out weeds, also splendid for poultry. Sow 50 pounds to the acre in June, July or August. See Current Price List for quotations.

D. \& B.'s GARDEN AND LAWN ENRICHER MAKES BETTER GARDENS AND MORE BEAU. TIFUL LAWNS

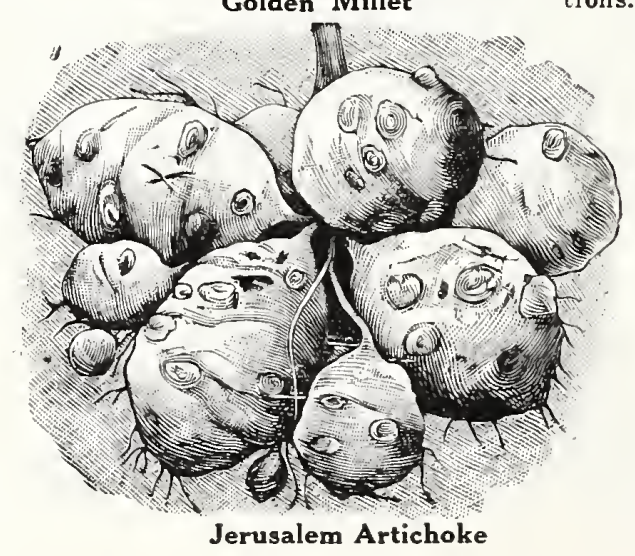

Dwarf

Essex Rape

Excellent grazing for all kinds of stock and poultry. Especially valuable for sheep and hogs with young, as it is an excellent milk producer. The young animals thrive on it and eat it with relish. It is hardy, stands cold, and is ready in eight weeks after sowing. Sow 10
Dwarf Essex Rape

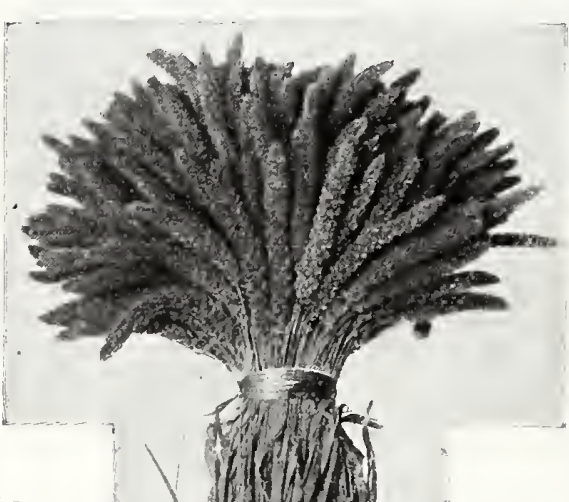
lbs. to the acre broadcast; 5 lbs. if drilled. Per lb. 18c; 5 lbs. 65c; 10 lbs. $\$ 1.05$, postpaid. Not postpaid, lb. 10c; 10 lbs. 70c. For prices on larger quantities, See Current Price List.

\section{Jerusalem Artichokes}

Artichokes are grown only from tubers, like Irish potatoes, and should be planted and cultivated in all respects like Potatoes. They are very prolific and make excellent hog feed; claimed to be very healthy for stock and said to be a preventive of cholera. The tops when cut and cured like fodder make good forage; we consider it a most valuable crop and those who raise hogs should not be without them. Can be gathered and fed or the hogs may be turned on the field to feed themselves. Per lb. 20c; 5 lbs. 55c; 10 lbs. 85c, postpaid. Not postpaid, lb. 10c; 10 lbs. 65c; per bu. of $50 \mathrm{lbs}$. $\$ 1.75$.

\section{Navy Beans}

A very profitable market crop, and the leading table bean. Only the dried beans are used. Plant in June or July in 3-foot rows; about $20 \mathrm{lbs}$. to the acre. Height 12 inches. See Current Price List for quotaions.

\section{Broom Corn} Standard Evergreen An imstrain of the well-known broom corn, but is hardier and produces a longer brush. Sow in May in rows 3 feet apart, and thin plants to 3 inches apart in the row. About 5 lbs, are required for an acre. Customers will find it profitable to grow broom corn and make their own brooms or sell it on the market. Per lb. 30c; 5 lbs. \$1.05, postpaid. Not postpaid, lb. 20c; 10 lbs. \$1.50. For larger quantities, see Current Price List. 


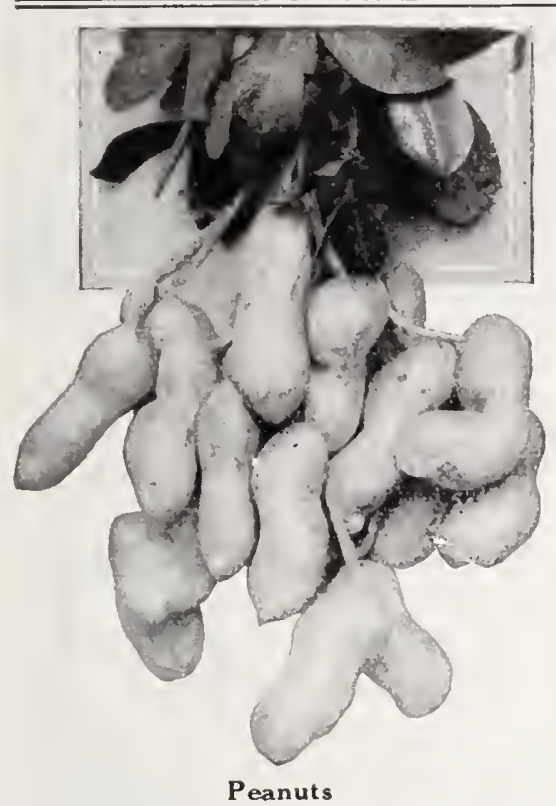

\section{PEANUTS}

Plant in May, 12 inches apart, in 3-foot rows. About 1 bushel in the hull is required to plant an acre and about $15 \mathrm{lbs}$. shelled nuts. Cultivate well, and at the last working leave loose earth close up around the plants. Peanuts should be shelled before planting.

Spanish Nuts small, and have a thin hull, full kernel, and yield enormously. The vines and roots make good food for stock. Nuts in the hull, lbs. 80c; 10 lbs. $\$ 1.35$, postpaid. Not postpaid, lb. 15c; 10 lbs. $\$ 1.00$. For quotations on larger quantities see Current Price List. Shclled nuts, per lb. 25c; 5 lbs. $\$ 1.00 ; 10$ lbs, $\$ 1.90$, postpaid. Not postpaid, lb. 15c; 10 lbs. \$1.20. For larger quantities, see Current Price List. Virginia Jumbo A large variwell-known Virginia Peanut. In the hull, per lb. 25c; 5 lbs. $85 \mathrm{c} ; 10$ lbs. $\$ 1.45$, postpaid. Not postpaid, lb. 15c; 10 lbs. \$1.10. Shelled Nuts, per lb. $25 \mathrm{c} ; 5 \mathrm{lbs} . \$ 1.00 ; 10 \mathrm{lbs} . \$ 2.25$, postpaid. Not postpaid, lb. 20c; 10 lbs. \$1.25. For larger quantities, see Current Price List.

Valencia These are dull red in heavy yielder, and have long pods, with 3 or 4 nuts in a pod. It is probably the hardiest Peanut in cultivation. It is mild in flavor and becoming more popular wherever grown. In the hull, lb. 30c; 5 lbs. 90c; 10 lbs. \$1.5., postpaid. Not postpaid, lb. 16c: 10 lbs. \$1.20. For larger quantities, see Current Price List.

\section{Mammoth Russian Sunflower}

This is highly prized by poultry raisers and farmers as a good food for fowls. It is very productive, easily raised, and on good land will yield more bushels of grain than corn. It is a good egg producing and fattening food. Seven to 10 pounds are required to plant an acre. Per lb. 20c; 5 lbs. $80 \mathrm{c}$, postpaid. Not postpaid, lb. 13c; 10 lbs. S0c. For larger quantities see Current Price List.

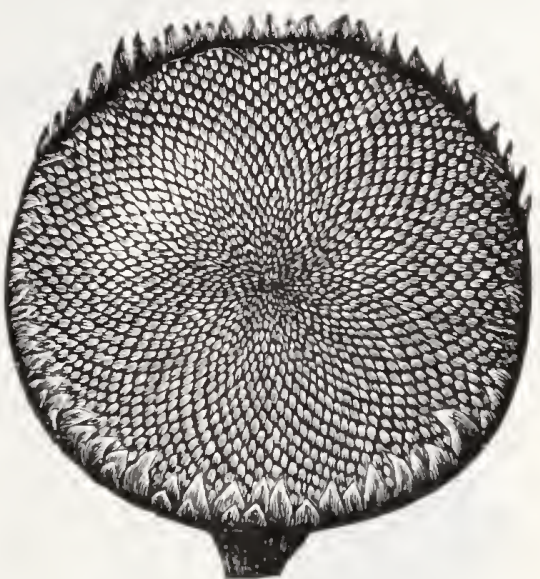

Mammoth Russian Sunflower

\section{Sorghum}

Sorghum or Sugar Cane should be sowed in May after danger of frost is past. For Syrup sow in rows 3 feet apart, about 15 lbs. to the acre. For fodder, sow broadcast about 75 lbs. to the acre. Sorghum should be more generally grown for making syrup. It is easy to grow and many people much prefer home-grown sorghum molasses to Southern syrups. Makes a splendid hay or green forage when seeded together with Cow Peas broadcast at the rate of 25 pounds of sorghum and 60 pounds of Peas to the acre. This combination should be sowed only on good land, however, when it will make a heavy crop of hay.

Sugar Drip This is decidedly the best variety for making syrup, also good for fodder, or green fced. I,b. 20c; 5 lbs. Early Amber Grows 10 to 12 feet high; yields heavy nutritious forage, either dry or cured; very sweet; also makes good syrup. Lb. 15c; 5 lbs. 50c, postpaid. Kaffir Corn A good forage crop. Makes a heavy growth; very nutritious; its grain to the acre broadcast; 30 pounds if drilled. Lb. 16c; 5 lbs. 55c, postpaid. Not postpaid, lb. $8 \mathrm{c} ; 10$ lbs. 50c. Larger quantities quoted on request.

\section{Vetch}

Sand, or Hairy Vetch A nutritious and valuable forage and soil-improving crop. ber, preferably with grain, which holds the Vetch well up off the ground. To get the best

INOCULATE THIS SEED WITH STIMUGERM results sow 20 pounds to the acre, together with 50 pounds of either Wheat, Oats, Rye or Barley. Per lb. 20c; 5 lbs. 80c; 10 lbs. \$1.40, postpaid. Not postpaid, lb. 15c; $10 \mathrm{lbs}$. $\$ 1.20$. For larger quantities, see Current Price List.
Poultry Litter or Peat Moss An excellent material for use as a floor coverScratching Pens. It is highly absorbent of Moisture. A Deodorizer. A Disinfectant. A Scratching Litter and a Dust Bath all in one. It keeps the Poultry Houses and Pens dry and healthy and is of exceptional value as a Fertilizer when finally removed. It is particularly valuable for use where Baby Chicks are kept. 50 lbs. \$1.50; per bale $\$ 2.25$.

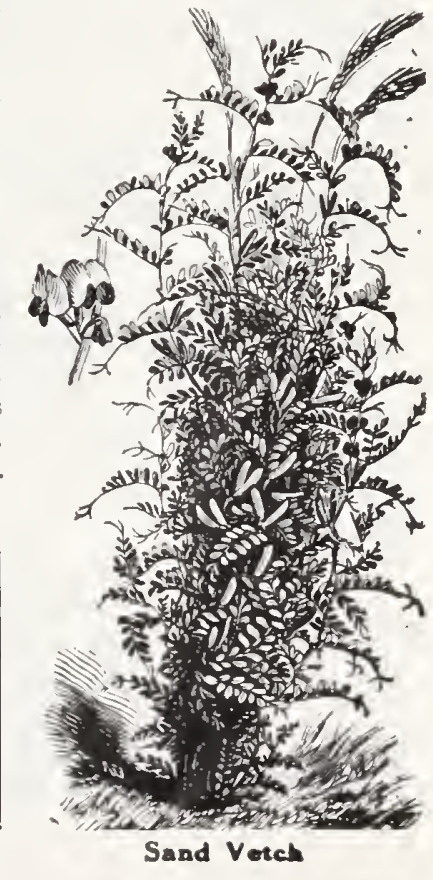




\section{Sundry Articles For The Gardener's Use}

\section{The "Little Wonder" Hedge Trimmer}

This handy little implement revolutionizes hedge trimming. It cuts from five to ten times as fast as by the old method of hand trimming and does far better work. It cuts clean and evenly, o perat es smoothly, and so easy to run that a lady can easily operate it. It trims every variety of hedge, fancy style, oval, square, and side

cuts on the hedge as high as four feet and at a slow walk.

Complete descriptive and illustrated pamphlet on request

No. $1-30$-inch cut........................ \$25.00

No. 2-40-inch cut.

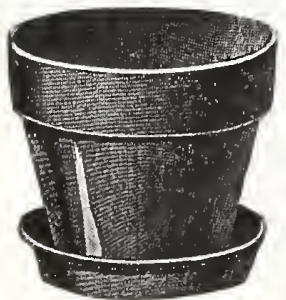

\section{Standard Flower Pots and Saucers}

Pots and Saucers cannot be mailed.

Extra charge will be made for packing for shipping at the rate of $35 c$ per order of $\$ 3.00$ or less; on large orders add for packing 10 per cent to the amount of order. While we pack all orders carefully we will not be responsible for breakage.

\section{Pots}

Diameter
$21 / 2$ inches
3 inches.
4 inches.
5 inches.
6 inches.
7 inches
8 inches.
9 inches
10 inches.
12 inches

$\begin{array}{rr}\text { Each } & \text { Dozen } \\ \$ .0 .1 & \$ . .35 \\ .05 & .40 \\ .05 & .45 \\ .07 & .75 \\ .10 & 1.10 \\ .15 & 1.75 \\ .20 & 2.30 \\ .30 & 3.50 \\ .40 & 4.50 \\ .80 & 9.50\end{array}$

Per 100 $\$ 2.00$ 2.50

3.50

6.00
8.75

14.00

18.75

28.75

36.75

78.50

Saucers

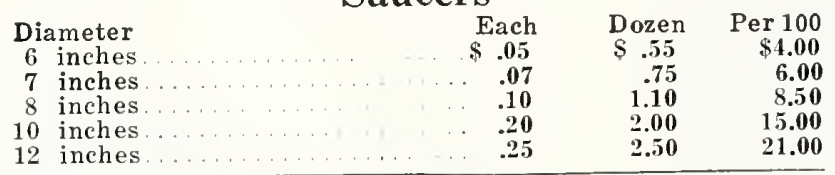

\section{Bird's $\begin{gathered}\text { IMPROVED } \\ \text { NEPONSET }\end{gathered}$ Flower Pots}
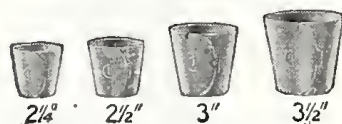

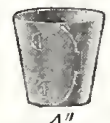

$4^{\prime \prime}$

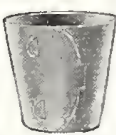

$5^{\prime \prime}$

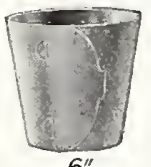

$6^{\prime \prime}$
These are water-proof paper pots. Used for starting plants under glass or in the house. Well made and can be used a number of times.

$2 \frac{1}{4}$ inch size..............50c per $100 ; \$ 4.00$ per 1,000 $21 / 2$ inch size..............60 per $100 ; \$ 4.75$ per 1,000 3 inch size...........75c per $100 ; \$ 6.50$ per 1,000 Postage extra, 10c per 100 .

Mulch Paper Laid between the rows of vegetables conserves moisture, increases the temperature of the soil, makes the vegetables ripen earlier. Tests made by Government and State Experimental Stations have showed a marked increase in the quantity and quality of vegetables when Mulch Paper was used. 18 inches wide. $10 \mathrm{yds}$. 30c; $100 \mathrm{yds}$. $\$ 1.75$; per roll of 300 yds. $\$ 3.50$.

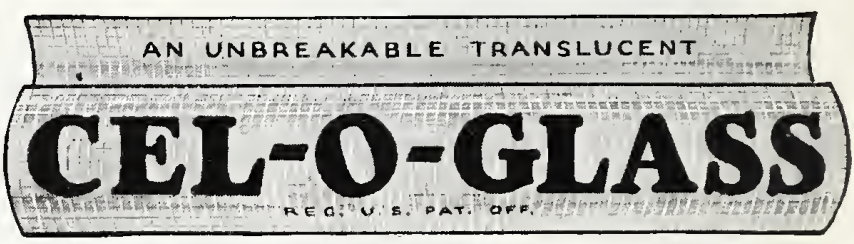

A practical and economical combination of woven wire and transparent composition for use as a substitute for glass on hot beds, sash, cold frames, windows, and, in fact, wherever glass can be used. Cel-o-glass is a most excellent substitute, flexible, light in weight, rainproof, heatproof, rustproof. Every market gardener, poultry raiser, farmer, florist, home owner and most every one needs Cel-o-glass. Just a hammer, some tacks and Cel-o-glass, a few seconds, and the job is finished. No bothering with putty and broken lights. Per roll of $81 / 3$ yds. $\$ 9.50 ; 162 / 3$ yds. $\$ 18.50$; $331 / 3$ yds. \$36.00. Mailing weight 1 pound to each yard.

Glass Cloth Not glass, but a Glass Cloth specially processed fabric for use on hot beds, etc. treated to render it transparent, weatherproof and waterproof, shutting out cold, snow, wind and rain; transparent to admit light and warmth. Per sq. yd. 35c; 10 yds. $\$ 3.00$; per roll of 100 yds. $\$ 27.50$. Mailing weight 1 pound to yard.

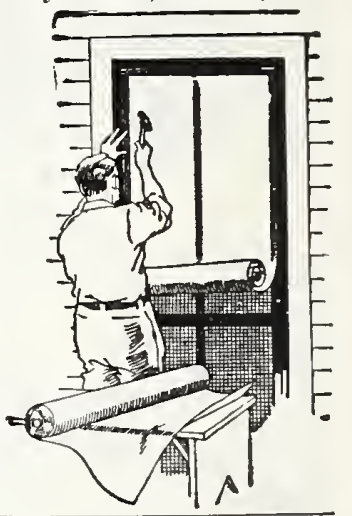

Glass for Hotbed Sash Per box of 90 inches. \$2.60. Subject to change.

Hotbed Sash Cypress, grooved without glass,

Mole Trap A strong galvanized trap. Should be placed over the run. $\$ 1.00$ each, (mailing wt. 4 lbs.).

Asparagus Knives Very handy and useful Each 35c. (Postpaid. 40c.)

Jute Twine For bunching vegetables, tying 2-ply or 3-ply.Per lb. 20c;10 lbs. and over@ @ 18c.

Raffia Used as substitute for twine for bunching vegeRafia tables and tying up vegetables and flowering plants to stakes. Per lb. 30 c; 10 lbs. $\$ 2.50$.

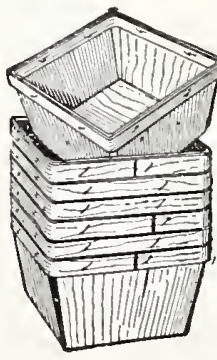

\section{Fruit Baskets}

For packing berries and fruits.

\begin{tabular}{|c|c|}
\hline & er 100 \\
\hline -pint size (oblong) . & $\$ .90$ \\
\hline $\begin{array}{l}\text { 1-quart size (square)... . with } \\
\text { 1-quart size (square), with } \\
\text { metal rim, per case of } 2,000, \\
\$ 15.00 \text {. }\end{array}$ & .90 \\
\hline quart size (oblong) .............. & 1.75 \\
\hline quart size (oblong) & 2.10 \\
\hline quart size (oblong) & 2.20 \\
\hline
\end{tabular}

RACKS For separating layers of fruit baskets in the crate, $\$ 3.00$ per 100 .

PEACH or TOMATO SHIPPING CRATES.

Holds 6 4-qt. baskets in knock down. Each $40 \mathrm{c}$.

32-Qt."BERRY CRATES, complete, filled with baskets, each $75 \mathrm{c}$; without baskets. $45 \mathrm{c}$ each.

2-Qt. Grape Baskets, with tops and handles, per 100, \$5.00. 4-Qt. Grape Baskets, with tops and handles, per 100, 6.50 .
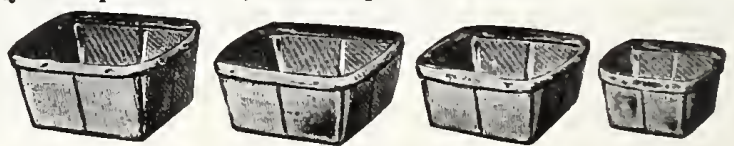


\section{D. \& B.'s RECLEANED BIRD SEEDS AND SUPPLIES}

The health of your song birds is directly dependent on fresh, clean seed.

All of our Bird Seeds are of the highest quality.

Add postage if ordered sent by mail.

D. \& B. SPECIAL MIXED BIRD SEED. This seed is thoroughly mixed by us in the proper proportions to form the correct ration for song birds. Per lb. 13c; 4 lbs. 50c; 10 lbs. $\$ 1.00$.

PLAIN CANARY SEED-Per Ib. 13c; 5 lbs. 55c; 10 lbs. \$1.00.

BIRD RAPE-Lb. 10c; 10 lbs. 90c.

IIEMP SEED-For pigeons, parrots and poultry feeding. Lb. 10c; $10 \mathrm{lbs}$. 75c.

SUNFLOWER SEED-A rich food for grown fowls and parrots. Lb. 13c; 5 lbs. $55 \mathrm{c} ; 10$ lbs. $\$ 1.00$.
BIRD MILLET-A large seeded Millet for bird feeding and baby chicks. Per lb. $10 \mathrm{c} ; 10$ los. $75 \mathrm{c}$.

BLUE MAW, or POPPY SEED-A good tonic for songsters. Keeps them in a strong, healthv condition. Lb. $40 \mathrm{c}$, postpaid. Not postpaid, lb. 30c.

BIRD MANNA-Keeps cage birds in constant song; improves their plumage and prevents disease. Pkg. 20c, postpaid. Not postpaid, pkg. 15c.

SILVER BIRD GRAYEL-36-oz. pkg. 15c; 2 lbs. for 25c. Loose gravel, lb. 5c; $6 \mathrm{lbs}$. for 25c, postage extra if mailed.
BIRD TONIC-For loss of song, weak. ness or moulting, asthma, colds, the shedding of feathers out of season and other diseases of caged birds, pigeons and poultry. 1-oz. bottle 15c (postpaid 20c) ; 3 oz. bottle $33 \mathrm{c}$, postpaid. Not postpaid, $25 \mathrm{c}$.

BIRD WASII-For use on Canaries, Parrots and other birds in captivity. Antiseptic and non-poisonous. 3-oz. bottle 33c, postpaid. Not postpaid, 25c.

CUTTLE FISI BONE-Lh, 50c, postpaid. Not postpaid, lb. $40 \mathrm{c}$.

FL $\triangle X$ SEED-L,b. 12c; 10 lbs, \$1.00.

\section{PLANET JR. GARDEN TOOLS}

The Planet Jr. Tools are the greatest savers of time and labor ever invented for cultivating the garden. They pay for themselves in a single season in larger, better and cleaner crops. No matter whether your garden is small or large, you should have a Planet Jr. Tool. They will do nearly all the work in the garden, after the ground is broken, from sowing the seed to the last working. For complete description and illustration of each tool, ask for Planet Jr. Catalogue.

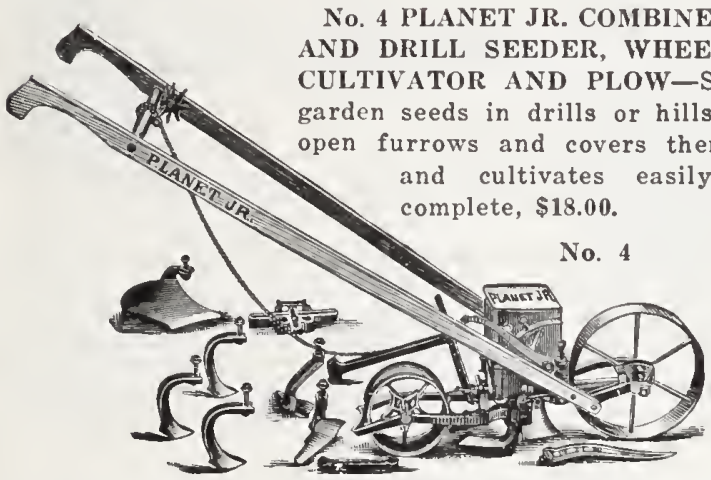

No. 4-D HILL AND DRILL SEEDER-Same as above, less the cultivating attachments. Price, $\$ \mathbf{1 4 . 2 5}$.

No. 11-PLANET JR. DOUBI, WHEEL HOE, CULTIVATOR, PLOW AND RAKE-A single and double wheel hoe in one. Straddles crops till 20 inches high, then works between. Price, \$13.75.

No. 12 PLANET JR. DOUBLE AND SINGLE WHEEL HOE -Same as No. 11, but without the Rakes and one pair of Hoes. The attachments sold with No. 12 are what gardeners use most, and the others can be added as wanted. Price, \$10.75.

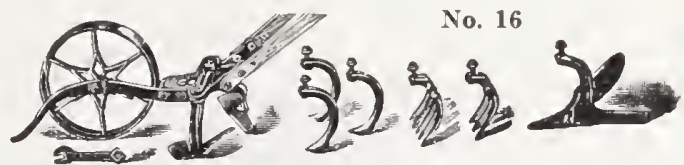

No. 16 PLANET JR. SINGLE WHEEL HOE, CULTIVATOR, RAKE AND PLOW-The highest type of single wheel hoe made. Light but strong. Price, $\$ \mathbf{9 . 0 0}$.

No. 17 PLANET JR. SINGLE WHEEL HOE-Same as No. 16, but without the Rakes and Leaf Lifter. These single wheel hoes have an outfit sufficient for most home and market garden work. Price, $\$ \mathbf{7 . 7 5}$.

No. 19 PLANET JR. SINGLE WIIEEL HOE-A light, but very strong wheel hoe. Price, $\$ 5.50$.

No. 25 PLANET JR. COMBINED HILL AND DRILL SEED. ER, DOUBLE WIIEL HOE, CULTIVATOR AND PLOW-A splendid combination for the family garden, onion grower, or large gardener. It is a perfect seeder and combined double and single wheel hoe. Price, \$21.50.

FIRE-FLY GARDEN PLOW-This tool is exceedingly useful to owners of small gardens. It will throw a furrow 4 to 6 inches wide and 1 to 3 inches deep, and deeper by going twice. This tool will enable a busy man to do in his spare minutes much of the work of a family garden. Chicken raisers find it of great advantage in plowing up scratching yards. Price, \$4.25. 


\section{POULTRY FEEDS}
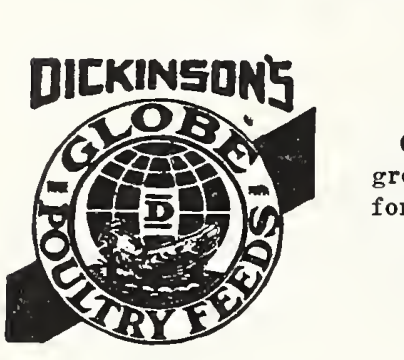

Add Postage If Order Mailed.

\section{THESE PRICES SUBJECT TO MARKET CHANGES}

GLOBE FEEDS are scientifically balanced and contain all the ingredients necessary to obtain results. There is a GLOBE FEED for every purpose. Get that best suited for your needs.

\section{GLOBE POULTRY FEEDS}

500 pounds at $10 \mathrm{c}$ per 100 less.

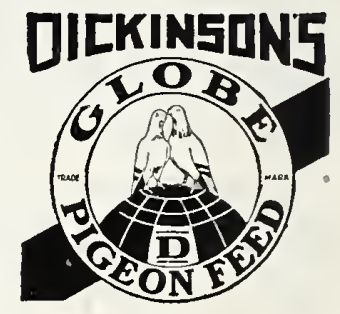

Globe Starting Ration With Dried Buttermilk. chicks for the first eight weeks. Everything needed to promote rapid, healthy, uniform growth is contained in this feed. Simply place Globe Starting Ration before your chicks in open hoppers when they are 48 to 60 hours old, and allow it to remain before them at all times. No other feeds are necessary. Globe Starting Ration reduces labor, reduces loss, promotes more uniform growth, and is economical to use. No more scratching around in dirty litter for the feed. It is all fed in the hoppers where it is kept clean and sanitary. 5 lbs. $25 \mathrm{c} ; 10$ lbs. $45 \mathrm{c} ; 25 \mathrm{lbs}$. $\$ 1.00$; 50 lbs. $\$ 1.75 ; 100$ lbs. $\$ 3.25$.

Globe Chick Scratch Made of the best of grains, to the proper size for chicks, and perfectly mixed. It is advisable to feed scratch grains in a trough or hopper, giving the chicks small amounts that they will eat readily; this will help to improve sanitary conditions. 6 lbs. 25c; 10 lbs. 40c; 25 lbs. 75 c; 50 lbs. $\$ 1.30 ; 100$ lbs. $\$ 2.40$.

Globe Growing Ration With Dried Buttermilk. time the chicks are eight weeks of age until maturity. It is impossible to get a good production of those high-priced "fall" eggs unless the pullets are properly fed through the summer so as to promote proper growth and development. Many poultry raisers make the mistake of feeding their pullets on grain alone during the summer, because they are not producing at that timc. The facts are that they need a feed at this time that carries exactly the right kinds and amounts of each of the necessary nutrients that promote growth and the development of the egg-making organs. Globe Growing Ration is a complete feed to be fed just as it comes from the bag. Like the Starting Ration, it saves time, it saves labor, it reduces disease, and it is the most economical ration to use. 6 lbs. $25 \mathrm{c}$; 10 lbs. $40 \mathrm{c} ; 25$ lbs. $75 \mathrm{c}$; 50 lbs. $\$ 1.40 ; 100$ lbs. $\$ 2.70$.
Globe Growing Scratch Cracked to the proper A mixture of clean, wholesome grains especially prepared to produce bone and rapid growth. 6 lbs. 25c; 10 lbs. 35c; 25 lbs. 75 ; 50 lbs. $\$ 1.20 ; 100$ lbs. $\$ 2.20$.

Globe Scratch Feed When fed in combination with Globe Egg Mash makes a perfect egg-making ration. Globe Scratch Feed makes the yolk of the egg, and Globe Egg Mash makes the whites. We consider this really the best Scratch Food on the market today. 10 lbs. $25 \mathrm{c} ; 25$ lbs. 60c; 50 lbs. $\$ 1.00 ; 100$ lbs. $\$ 1.85$.

Rival Scratch Food An economical but a good clean grains. Per $100 \mathrm{lbs} . \$ 1.75$.

Globe Laying Ration For the poultryman who complete does not raise grain. A advantage of the Globe Method of feeding. 5 lbs. $25 \mathrm{c}: 10$ lbs. $40 \mathrm{c} ; 25$ lbs. $75 \mathrm{c} ; 50$ lbs. $\$ 1.30 ; 100$ lbs. $\$ 2.40$.

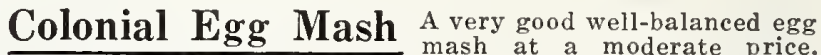
per 100 lbs. $\$ 2.15$.

Globe Utility Pigeon Feed Is made of selected chosen because of their milky content. Squabs thrive on it. 10 lbs. $45 \mathrm{c}: 25$ ibs. $90 \mathrm{c} ; 50 \mathrm{lbs}$. $\$ 1.60 ; 100 \mathrm{lbs}$. $\$ 3.00$.

Globe Pigeon Feed This is a good well-balanced will suit those who are looking for a good, all around feed 10 lbs. 50c; 25 lbs. $95 \mathrm{c} ; 50$ lbs. $\$ 1.80 ; 100$ lbs. $\$ 3.50$.
Meat Meal 55 per cent protein. An excellent egg10 lbs. 50c; 25 lbs. 85 c; 50 lbs. $\$ 1.45 ; 100$ lbs. $\$ 2.65$.

Valentine's Meat Meal An excellent meat meal for $\frac{}{65}$ per cent protein. 10 lbs. 55c; 25 lbs. $\$ 1.25 ; 50$ lbs. $\$ 2.40$; 100 lbs. $\$ 4.65$.

Alfalfa Leaf Meal This is Alfalfa Leaf, cured To be fed in a mash, or dry; can be used alone or mixed with other mash food. It is an excellent substitute for green grass, and increases egg production in winter. 10 lbs. $45 \mathrm{c} ; 50 \mathrm{lbs}$. $\$ 1.90 ; 100 \mathrm{lbs}$. $\$ 3.60$.

Crushed Oyster Shells Indispensable for successids digestion and the formation poultry keeping, as it have it where the fowls can get at it all the time, as they will not eat any more than they need. In ordering please state whother the "fine" size is wanted for chicks and pigeons, or the "regular" size for grown fowls. 10 lbs, 20c; 25 lbs. 30c; 100 lbs. $75 \mathrm{c}$.
Hen's Teeth Poultry Grit This grit is manufacpoultry. It is essential in the poultry yard, to keep fowls in a healthy condition. 3 Sizes: For Hens, Growing Chicks, Baby Chicks and Birds. 10 lbs. $20 \mathrm{c} ; 25$ lbs. $40 \mathrm{c} ; 50$ lbs. $50 \mathrm{c}$; 100 lbs. 85c.

Red Cross Health Grit A superior grit prepared pronounced by pigeon fanciers an excellent grit. Keeps the birds vigorous and healthy. 10 lbs. 35c; 50 lbs. \$1.25; 100 lbs. $\$ 2.25$.

Poultry Charcoal We have this charcoal put up to Poultry Charcoal meet the demand for an evenly graded charcoal, free from dust and useless dirt. Charcoal aids digestion, promotes health, and is generally corrective of many of the poultry ills to which fowls are heir. A little charcoal goes a long way and is worth its weight in gold. No poultryman can afford to be without it. It is put up in three sizes-Fine, for chicks; Medium, for half-grown fowls and pigeons; Coarse, for full-grown fowls. When ordering state what size is wanted. 2-1b. pkg. 15c; 10 lbs. 40c; 50-lb. sack, $\$ 1.10 ; 100$ lbs. $\$ 2.10$. 


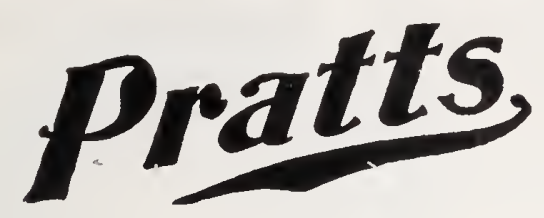

\section{Poultry and Animal Regulators and Remedies}

\section{FOR POULTRY}

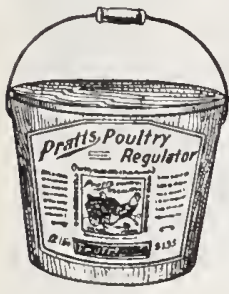

POULTRY REGULATOR (For Health and Eggs)-It is a natural tonic supplying numerous health necessities required by heavy laying hens. Tones up the system, regulates the bowels, paid $\$ 1.10$ ).

aids digestion, sharpens appetite, wards off disease and increases vitality. Use it for breeders, layers and growing stock. Pkg. 25c (post wt. 3 lbs.); pkg. 50c (post wt. 5 lbs.); 9-lb. pkg., $\$ 1.10 ; 12$-lb. pkg., $\$ 1.40 ; 25$-lb. pail, $\$ 3.00$.

R-P TABLETS-Formerly Called Roup Tablets-Use it as a treatment or preventive. An easy, powerful remedy with a long record of success in the treatment of colds, "roup," canker, catarrh, etc. Keep a box always at hand. Pkg. 25c (postpaid 30c); large pkg. 50c (postpaid 55c).

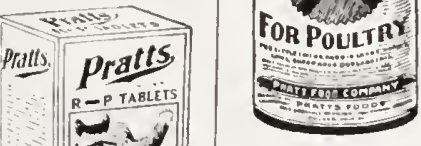

POWDERED L I C E

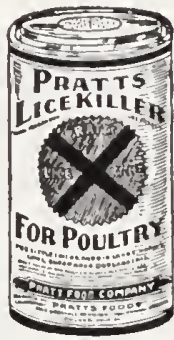
KILLER-Effective, nonirritating. It quickly and thoroughly kills lice on little chicks, big chicks, setting hens and incubator chicks. It rids horses, cattle, hogs, dogs and cats of lice, and destroys ticks on sheep. It destroys many insects and bugs on vines, plants and flowers. Drives out moths from closets, furniture, car. pets and clothing. In sifter top cans. Pkg. 25c (post wt. 2 lbs.); pkg. 50c (post wt. 3 lbs.); 6 lb. pkg. $\$ 1.00$.

POULTRY DISINFECTANT-Insures Pratts. DPUPREMED ROUP POWDER - Small pkg. 25c (postpaid 30c);

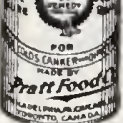
large pkg. 50c (postpaid $55 \mathrm{c})$.

CHICK TABLETS Formerly Called Chick Diarrhea Tablets-Use this in the chicks drinking water for the first ten days and you will avoid losses from most common bowel troubles. This is "life insurance" for chicks that will save you dollars. Very easy to use. SmaIl pkg. 25c (postpaid 30c); large pkg. 50c (postpaid 55c); 7-oz. pkg. $\$ 1.00$ (postpaid \$1.05).

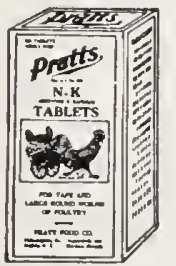

N-K TABLETS-Fresh, powerful Nicotine and Kamala, encased in a special insoluble coating which, when crushed by grit in gizzard, releases contents into intestines, quickly killing round and tape worms. A guaranteed individual treatment. Chick size, 50 tab. lets, 65c (postpaid 70c); adult size, 50 tablets, $\$ 1.00$ (postpaid $\$ 1.05$ ). poultry health. It is a cheap, powerful

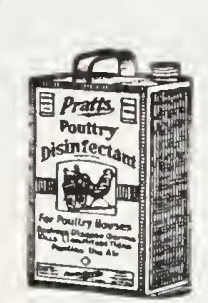
non-poisonous disinfectant. Spray it about poultry houses, roosts, dropping boards, nests and where ever a strong disinfectant is needed. A deodorized,germicide and liquid lice killer. Effective in the treatment of roup, colds and contagious diseases. Pt. 35c; qt. 55c; 2-qt. 90c; gal. \$1.50. Cannot mail.

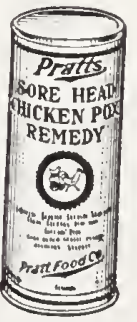

SPECIAL COMPOUNDFor indigestion, sour craw. dysentery and other troubles. Small pkg. 25c; large pkg. 50c (post wt. 1 lb. each).

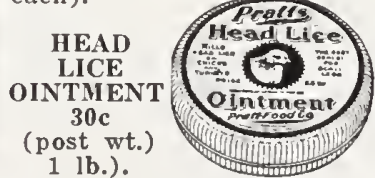

SORE HEAD AND CHICKEN POX PREPARATION-35c and 70c (post wt. 1 lb, each).

\section{GAPE COMPOUND}

For internal use. Pkg. 25c; large pkg. 50c (post wt. 1 lb. each size).

For external use, dusting on. Small pkg. $25 \mathrm{c}$ (post wt. 1 lb.). Large pkg. 50c (post wt. 2 lbs.).

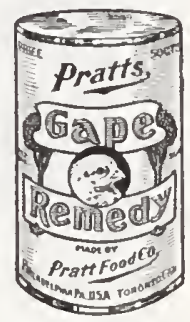

RED MITE SPECIAL-1-qt. can 50c; 2-qt. can 90c; 1 gal. can $\$ 1.50$. Cannot mail.

BRONCHITIS REMEDY-Pkg, 30c; large pkg. $60 \mathrm{c}$ (post wt. each size 1 lb.).

CONDITION TABLETS-For poultry. Small pkg. 25c (postpaid, 30c); large pkg. 50c (postpaid, 55c).

LICE SALVE-Kills chicken lice and nits. Pkt. 25c (postpaid 30c).

\section{FOR STOCK}

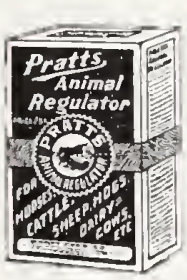

ANIMAL REGULATOR. For Horses, Cows, Sheep and Hogs. Unexcelled as a tonic and conditioner, improves health, aids digestion, regulates the bowels. Helps horses do more work and cows give more milk. Pkg. 25c (post wt. 2 lbs.); pkg. 50c (post wt. 4 lb.);

25-lb. pail, $\$ 3.00$.

LINIMENT - Excellent for healing sores on stock. Per bottle 35c (post wt. 1 lb.).

FLY CHASER-2-qt. can $80 \mathrm{c}$; 1-gal. can $\$ 1.30$. Cannot mail.

HEALING O I N T MENT - Pkg. 25c (postpaid $30 \mathrm{c}$ ).

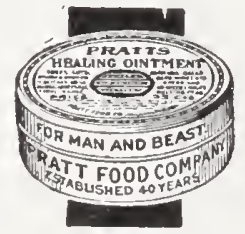

HOG TONIC-Pkg. 50c (post wt. 4 lbs.). 


\section{Standard Poultry and Stock Remedies}

\section{Dr. Hess and Clark Poultry} and Stock Preparations
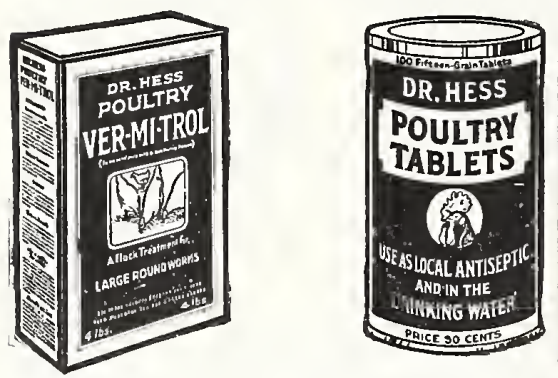

DR. HESS IMPROVED STOCK TONIC -Splendid for all kinds of stock, promotes health, makes cows more profitcondition; has been serving the farm and dairy interests of the country for upwards of 35 years. 5-lb. pkg. 75c; 15-lb. pkg. $\$ 2.00 ; 25-\mathrm{lb}$. pkg. $\$ 3.00 ; 100-$ lb. drum $\$ 10.00$. Postage extra.

DR. HESS POULTRY PAN-A-MINKeeps poultry healthy, makes hens lay, is not a stimulant but a Tonic that tones the dormant egg organs; contains internal antiseptics to counteract disease; insures a healthy, singing flock. Has been known to poultry raisers for more than 30 years as Dr. Hess Poultry Pana-ce-a. 3-lb. pkg. 50c; 7-lb. pkg. $\$ 1.00$ 15-lb. pkg. \$2.00; 25-lb. pkg. \$3.00. Postage extra. 100 lbs. $\$ 10.00$.

DR. HESS POULTRY VER-MI-TROLEffective for worms in poultry; a flock treatment, no individual handling of birds. Is given with the feed in ten-day courses, three weeks apart, with Dr. Hess Poultry Pan-a-min fed regularly every day. 4-lb. pkg. $\$ 1.25 ; 10-1 b$. pkg. $\$ 2.75$. Postage extra.

DR. HESS POULTRY TABLETS-O high value in treating Roup; slightly astringent, non-irritating, and healing. Use as a local antiseptic and to medicate drinking water. Thus used they aid in preventing the disease. Once dissolved they remain in solution. The water needs no further stirring. Pkg., 100 tablets, 50c (postpaid 55c); pkg., 225 tablets, $\$ 1.00$ (postpaid $\$ 1.10$ )

DR. HESS CHICK TABLETS - Effective for diarrhoeal diseases of both baby chicks and grown fowls; a bowel astringent given in drinking water. Once the tablets are in solution they remain so indefinitely. The water is thoroughly medicated and is all good until used Pkg., 100 tablets, 50c (postpaid 55c): pkg., 225 tablets, $\$ 1.00$ (postpaid $\$ 1.10$ )

DR HESS INSTANT LOUSE KILLER - Kills lice on contact. For poultry, horses, cattle, sheep and hogs; also bugs on cucumber, squash and melon vines, worms on cabbage, rose bushes, etc. 1lb. pkg. 25c (postpaid 30c); 21/2-lb. pkg. $50 \mathrm{c}$ (postpaid 60c)

DR. HESS DIP AND DISINFECTANT -For Stock Dipping and general disinfecting; kills lice and other vermin. Makes a milk-white emulsion, no streaks or settlings; is standardized with an established carbolic acid co-efficient. Always uniform in strength. 12-oz. bottle $40 \mathrm{c}$; 1-qt. can $60 \mathrm{c}$; 1-gal. can $\$ 1.75$; 5 gals. $\$ 7.50$. . Cannot mail.

\section{Conkey's Poultry Remedies}

These reliable remedies are well known and are guaranteed to cure when used according to directions. Valuable Conkey Pamphlet mailed free on request. Full directions for using with each package.
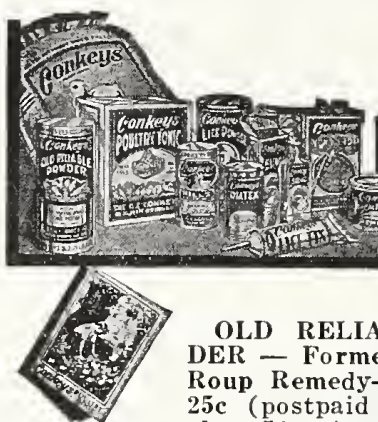

OLD RELIABLE POWDER - Formerly Called Roup Remedy-Small pkg. 25c (postpaid 31c); large pkg. $50 \mathrm{c}$ (postpaid 56c); 7-oz. pkg., fancier's size, $\$ 1.00$ (postpaid $\$ 1.10$ ); 5-lb. pkg. $\$ 5.50$ (postpaid \$5.65).

CONKEY PILLS - For Roup - Small pkg. 25c (postpaid 30c); large pkg. 50c (postpaid 58c).

CONKEY DIATEX - Formerly Called White Diarrhea Remedy-Small pkg., 30 tablets, 25c (postpaid 31c); large pkg., 75 tablets, 50c (postpaid 56c); Fancier's size, 175 tablets, $\$ 1.00$ (postpaid $\$ 1.10$ ).

CHOLERA REMEDY-Small pkg. 25c (postpaid 32c); large pkg. 50c (postpaid 56c.) Fancier's size, 10-oz. phg. $\$ 1.00$ (postpaid $\$ 1.10$.)

GAPE REMEDY-Small pkg. 25c (postpaid 31c); large pkg. 50c (postpaid 56c).

SCALY LEG REMEDY-Small pkg. $25 \mathrm{c}$ (postpaid 31c). Large pkg. 50c (postpaid sc).

SORE HEAD REMEDY - Pkg. 50c (postpaid 55c).

POULTRY WORM REMEDY-Large pkg. 50c (postpaid 56c).

BALMO - For canker, colds, bronchitis, swelling and sores. pkg. 50c (postpaid 55c).

POULTRY LAXATIVE-Pkg. 25c (postpaid 31c); large pkg. 50c (postpaid 60c)

Y. O.-Yeast and Cod Liver Oil1 lb. 55c (postpaid 65c); 2 lbs. $\$ 1.00$ (postpaid $\$ 1.10$ ); 5-lb. pkg. $\$ 2.00$ (postpaid \$2.15).

POULTRY TONIC-Pkg. 25c (postpaid $35 \mathrm{c}$ ); 31/4-1b. pkgs. 50c (postpaid 60c); 12-1b. pail $\$ 1.60$.

LICE POWDER-15-oz. pkg. 35c (postpaid $40 \mathrm{c}$ ); 48-oz. pkg. 75c (postpaid $85 \mathrm{c}$ ).

NOX-I-CIDE-A splendid disinfectant and insecticide, very powerful and a small quantity will go further than most disinfectants. Recommended for use in the house, poultry house and stable. 1pint can $50 \mathrm{c}$; 1-quart can $80 \mathrm{c}$; 2-quart can $\$ 1.30$. Cannot mail.

FLY KNOCKER-Is recommended for spraying all kinds of stock and stables for keeping off the flies; an effective preparation. 2-qt. can 90c; 1-gal. can \$1.50. Cannot mail.
W A L K O R O P P, CHOLERA and WHITE DIARRHOEA TABLETS Especially valuable for white diarrhoea among incubator chicks. Tend to increase strength and vitality and should be given in drinking water as a preventive from the time chicks are out of the shell. Small pkg. 50c; large pkg. $\$ 1.00$, postpaid.

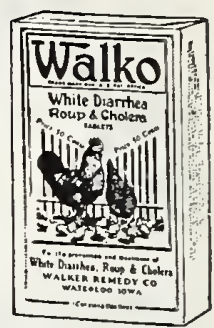

\section{A High Grade Dog Food}

C. L. O. VEGETABLE MEAT BISCUIT (Whole or Kibbled)

This is a carefully balanced ration, composed of wheat, rice, a large percentage of lean meat, best suited to the dog's digestive powers, and Cod-Liver Oil, all in proper proportion and thoroughly baked, ready to feed. It has no "filler," only 6.89 per cent moisture, is unusually high in nutritive value, rich in vitamines, keeps the dog's bowels regulated and free of bacteria and worm larvae.

It is of especial value for growing pups, dogs doing hard work, or out of condition. It does not fatten, but builds up bone and muscle, prevents rickets, keeps the coat glossy, the eyes bright and the dog enjoys it every day in the year. Ask for booklet "How to Feed the Dog."

10 -lb. trial bag $\$ 1.00$ (postpaid $\$ 1.20$ ); 25 -lb. bag $\$ 2.50 ; 50$-lb. bag $\$ 4.75 ; 100$-lb. bag $\$ 9.00$.

\section{Spratt's Dog Biscuits}

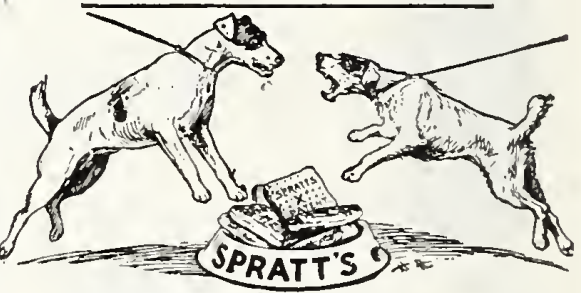

OVAL BISCUITS-A small but nutritious meat biscuit of superior quality for dogs of all breeds and sizes. 9-oz. pkg. 20c (postpaid 25c),

DOG SOAP-Death to fleas. Per cake 25c (postpaid 32c).

Salvet for Hogs and Stock

A medicated Salt which rids all stock of stomach and intestinal worms, aids digestion. 5-lb. pkg. 60c; 10-lb. pkg. $\$ 1.00$; 25 lbs. $\$ 2.25 ; 50$ lbs. $\$ 4.00 ; 100$ lbs. $\$ 6.75$.

Black Leaf 40 A solution of phate containing 40 per cent Nicotine prepared by the Tobacco By-Products Chemical Corporation. It is most effective for delousing poultry. To kill lice on poultry, simply paint the roost full strength just before roosting time and it effectively rids the poultry of lice and vermin. One-half pound will paint about 100 running feet. $1 \mathrm{oz} .35 \mathrm{c} ; 5 \mathrm{oz} . \$ 1.00$; lb. $\$ 2.50 ; 2$ lbs. $\$ 3.75 ; 5$ lbs. $\$ 7.00 ; 10$ lbs. $\$ 11.85$. Cannot mail. 


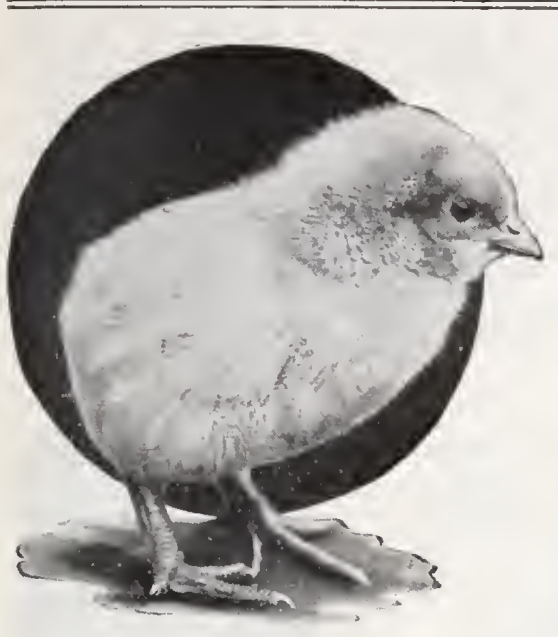

BREED

Barred Rocks

Rhode Island Reds

White Leghorns

White Wyandottes

Heavy Mixed (for Broilers)

Prices after February 15 th, $\$ 1.00$ per 100 less than above prices.

\section{Day-Old BABY CHICKS}

We guarantee 100 per cent live delivery.

These are delivered prices by parcel post fully prepaid. let us book your order three weeks ahead. Shipments made on Mondays and Thursdays. Ready January 15 th to June 1st. C. O. D.

\begin{tabular}{rrrrr}
\hline \multicolumn{5}{c}{ Postpaid Prices per- } \\
25 & 50 & 100 & 500 & \multicolumn{1}{c}{1.000} \\
$\$ 4.00$ & $\$ 7.00$ & $\$ 13.00$ & $\$ 60.00$ & $\$ 115.00$ \\
3.75 & 6.50 & 12.00 & 55.00 & 110.00 \\
4.25 & 7.50 & 14.00 & 65.00 & 125.00 \\
$\mathbf{3 . 7 5}$ & 6.50 & $\mathbf{1 2 . 0 0}$ & $\mathbf{5 8 . 0 0}$ & 110.00
\end{tabular}

To insure delivery on dates desired.

Cash with Order-No Chicks sent

\section{INCUBATORS AND BROODERS}

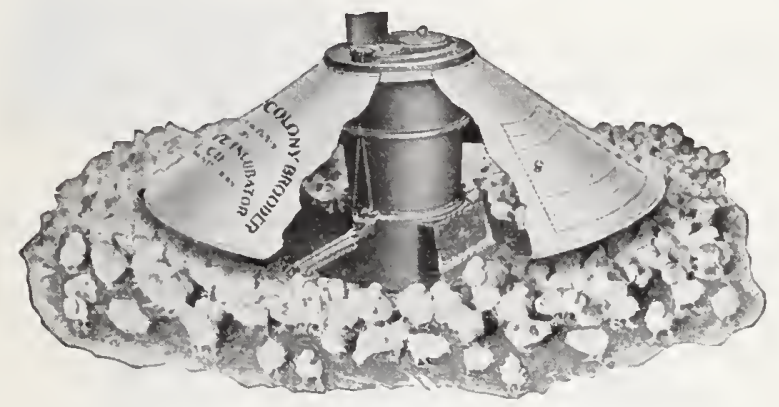

Buckeye Coal-Burning Brooder

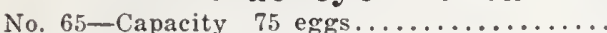
No, 67-Capacity 286 eggs with Automatic Egg Turners $\mathbf{5 7 . 7 5}$ No. 68-Capacity 416 eggs with Automatic Egg Turners 76.50 No. 69-Capacity 576 eggs with Automatic Egg Turners 97.50

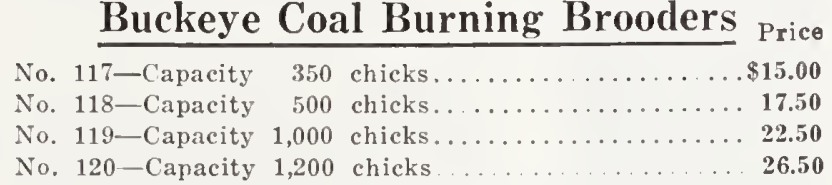

\section{Wickless Automatic Control}

No. 103 -Rite-Heat 500 Chick Capacity-52-in. Canopy $\$ 29.50$ No. 104-Rite-Heat 1200 Chick Capacity-62-in. Canopy $\mathbf{3 1 . 5 0}$ No. 154 -Even-Heat 500 Chick Capacity-54-in. Canopy 21.50 No. 162-Even-Heat 1200 Chick Capacity-62-in. Canopy $\mathbf{2 3 . 5 0}$

\section{Putnam Brooder Heater}

An economical little Brooder Heater, simple and easy to operate, perfectly ventilated. Holds 1 quart of oil and burns 10 days without attention. This Heater is made to be used in a home-made Brooder. Provides sufficient heat for 100 chicks or more. Price \$4.75.

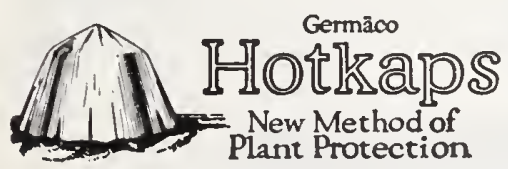

Patented wax paper cones making individual miniature hot houses. 11 in $\mathrm{ches}$ across at base. Protects plants from frost, wind, rain and insects. Insures earlier maturity, a better crop and keeps the soil moist. Inexpensive, are quickly and easily set.

Per 100 caps, \$2.50. Per 250 caps, \$4.00, including card board setters. 1,000 caps, $\$ 11.00$. Metal setters extra, $\$ 2.50$ each. Extra card board setters, 50c each.

\section{White Pekin Ducklings}

Orders booked for delivery after February 15th. Per 25, \$7.50; per $50, \$ 14.00$; per $100, \$ 27.00$.

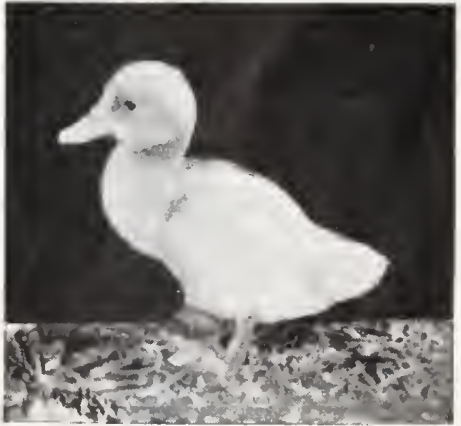




\section{POULTRY SUPPLIES AND APPLIANCES}

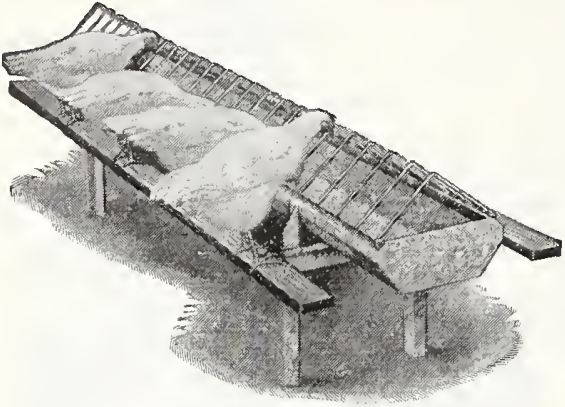

DREWS POUL. TRY TROUGHJust the thing for feeding mash or other feeds to grown fow $1 \mathrm{~s}$. Keeps feed clean. Strongly made. 18 inches high. 60 inches long. 10 inches wide. 4 inches deep. Holds 50 lbs. $\$ 6.00$.

G L O B

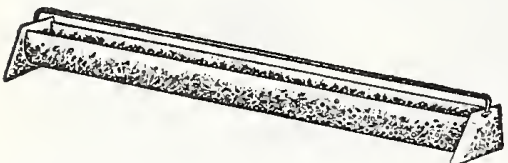
WASTE" M A $\mathrm{SH}$ F E E D E R S - For chicks. Made of galvanized iron; sanita $\mathrm{ry}$, economical, and handy; easy to fill, no covers. Chick can neither get into it or on it. One of the best baby chick feeders. 24-inch size 25c; mailing weight 2 lbs. 42-inch size 50c; mailing weight 3 lbs. 42 -inch large chick size 90c; mailing weight 5 lbs.

GLOBE "NO WASTE" MASH HOPPERS - For grown fowls; made of heavy galvanized iron 5 feet long, 8 inches wide and 5 inches deep. Holds 50 pounds of Mash feed. Birds cannot roost on or get into them. A substantial, sanitary and feed-saving hopper. Price $\$ 3.75$.

PAIL TYPE POULTRY WATERER-Ideal for small flocks. Practical, convenient and durable. Made of the best grade heavy galvanized rust resisting sheet steel. Holds 2 gallons. Insulated. Price \$3.00. (Mailing weight 10 pounds.)

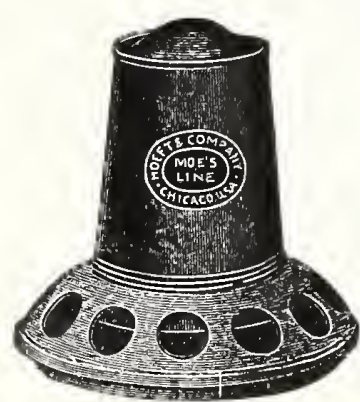

FELKER'S OPEN TOP FOUNTAIN - The tank is firmly attached to a heavy one-piece circular pan and fills from the top. They are strong and durable. 3 gal. size $\$ 1.75 ; 5$ gal. $\$ 2.25$. (Mailing weight 10 pounds.)

MAGAZINE CHICK FEEDER AND WATERER-The top magazine is water and air tight, so can be used as a Feeder or Fountain. Adjustable for various kinds of feed. Capacity 2 quarts, 12 holes, $35 \mathrm{c}$ each. Mailing weight 5 lbs.

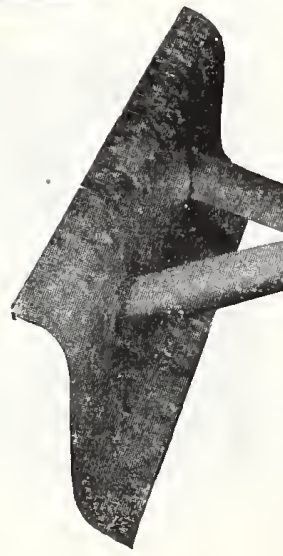

DROPPINGS BOARD SCRAPER - The usefulness of this handy scraper is at once appreciated as it makes cleaning the poultry house a quick easy task. The blade is made of heavy galvanized steel. 18 inches long. 6 inches wide. Handle 70 inches long. Price $\$ 1.35$ Cannot mail.

ROUND BABY CHICK FEEDER-Insures pure food for the chicks. A great feed saver, as the chicks cannot get into it and contaminate the feed, also used for water. Small size with 8 holes, 10e; large size, with 12 holes, 20c (post wt., each size, 2 lbs.).

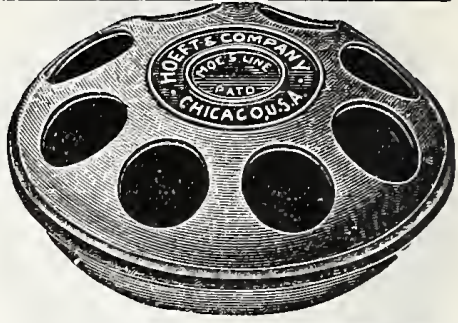

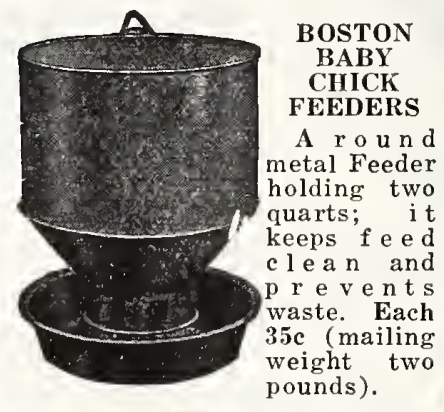

DRY MASH HOPPERS-With wire screen in front. Mice and rain proof.

8-qt. size

$\$ 1.25$

16-qt. size

LARGE CAPAC. ITY MASH FEEDER -Has sixteen openings on each side so that thirty - two chicks can feed at one time. Chicks cannot roost on the cover or sides, making it impossible to soil the feed. Has a sliding top, easy to fill and clean. A time and labor saver where chicks are raised in large numbers. Made of heavy galvanized iron. Capacity 10 quarts. Each $\$ 1.10$ (post weight 8 lbs.). 17-quart size, each $\$ 1.75$ (post weight 8 lbs.).

ROOF SADDLE-With this you can set up any brooder stove in any building. Simple, durable, easy to attach. Adjustable to roof. Each $\$ 1.80$ (mailing weight $10 \mathrm{lbs}$.).

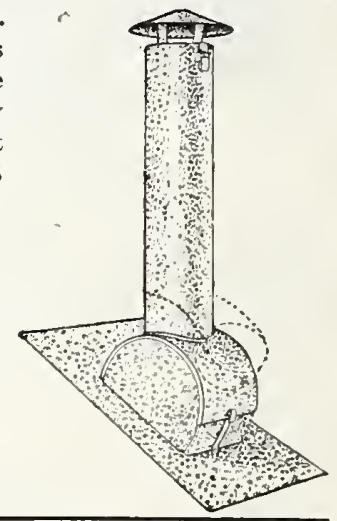




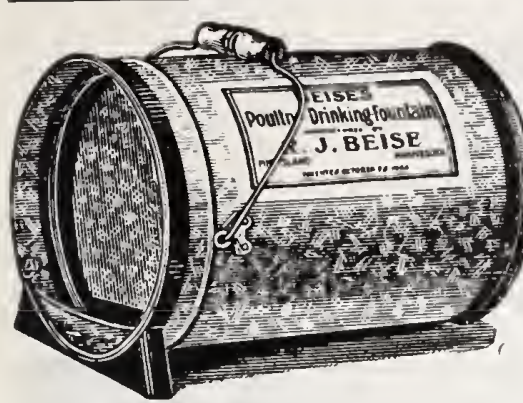

BEISE FOUNTAIN -Fills same as pail; simple and durable; does not spill when laid down; the convex front prevents fountain from bursting in freezing weather; has no square corners for dirt to lodge in. All fountains except 3-quart size are equipped with bail which prevents crowding small or weak chicks. The fountain stands on three points, raised from the ground, allowing a free circulation of air about it which insures long life and cleanliness. Water is kept clean until used up. 3-qt. size, each 65c (post weight 3 lbs.); 2-gal. size, each $\$ 1.00$ (post weight 5 lbs.); 3 -gal. size, each $\$ 1.15$ (post weight 5 lbs.); 4-gal. size, each $\$ 1.25$ (post weight 6 lbs.).

B OS T ON DRINKING FOUNTAIN-A convenient and handy fountain for all fowls except baby chicks. 1-qt. size $40 \mathrm{c}$ (mailing wt. 2 lbs.); 2-qt. 50c (mailing wt. 2 lbs.).
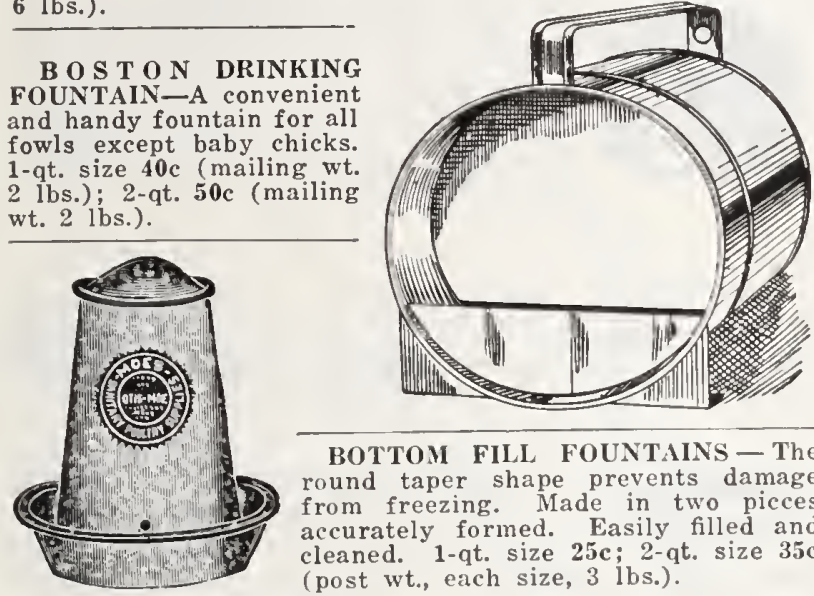

BOTTOM FILL FOUNTAINS - The round taper shape prevents damage from freezing. Made in two picces accurately formed. Easily filled and cleaned. 1-qt. size 25c; 2-qt. size 35c (post wt., each size, 3 lbs.).

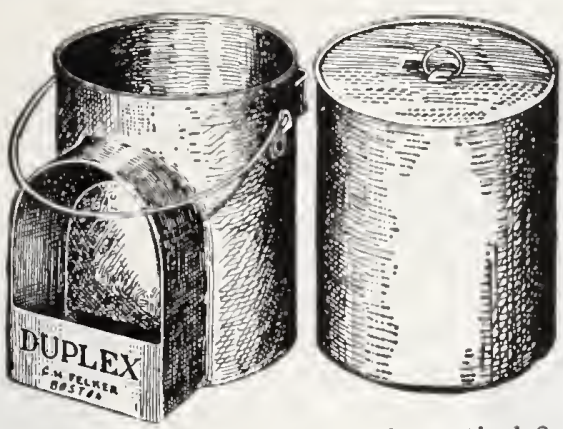

DUPLEX FOUNTAIN-A handy and practical 2-piece double fountain. Top section, slides into bottom section keeps the water clean and pure. 4 -qt. size $\$ 1.15$ each (post wt. 5 lbs.

MASON JAR FOUNTAIN BASEWill fit either quart or half-gallon Mason Jar. Made of one piece, cheap and sanitary. Each 10c (postpaid 20c); per doz. $\$ 1.10$ (postpaid \$1.40) jar not included.
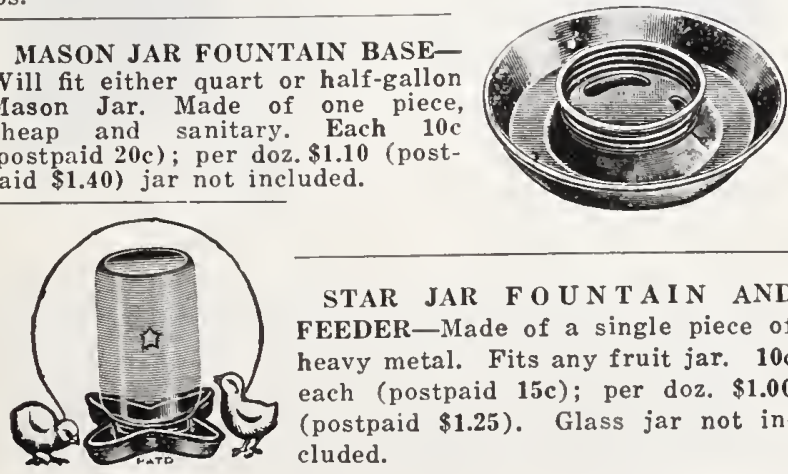

STAR JAR FOUNTAIN AND FEEDER-Made of a single piece of heavy metal. Fits any fruit jar. 10c each (postpaid 15c); per doz. $\$ 1.00$ (postpaid \$1.25). Glass jar not included.

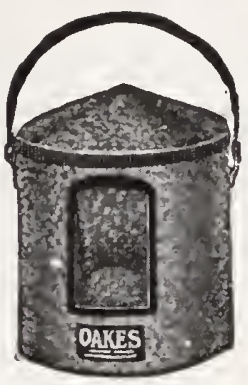

OAKES SANI-TIIERMO FOUNTAINBuilt like a thermos bottle with twoinch insulation. Keeps water cool in summer and warm in winter. Fills from the top. Easy to wash. Heavy wire bail for carrying. Made of heavy galvanized iron. Holds 3 gallons. \$4.50. Mailing weight 25 lbs.

CLAY DRINKING FOUNTAIN (Made of burnt clay)-These are two piece or bottom fill fountains with drinking basin at bottoin. 2-qt. 40c;1-gal. 50c. Cannot mail.

STOYE FOUNTAIN-Bottom filled. For water or buttermilk. Rust proof and non-corrosive. 1/2-gal. size 55c; 1-gal. size 65c.

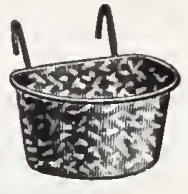

DRINKING CUP OR FOOD I'AN-This is half round, galvanized, made to hang in poultry or rabbit coops for holding food and water. $3 / 4$-pt. size 25c; $3 / 4$-qt. size $35 \mathrm{c}$ (mailing wt. 1 b. each).

BIRD FEED CUPS-Made of china. For canary birds. Hooks on cage. Used for feed or water. 15c each (postpaid 20c).

GRIT, SIIELL AND CIIARCOAL BOXES-3 partitions, 75c (mailing weight 3 lbs.).

LITTLE PUTNAM STOVE-To keep the hens laying throughout the winter, they should always have plenty of water in their pens, at a moderately warm temperature which they will drink. This stove gives it to trouble. It is made of galvanized iron 9 inches in diameter, 4 inches hir oil burner, tank holds 3 pints and burns 3 weeks or more without filling. \$1.95 each (post weight : lbs.).
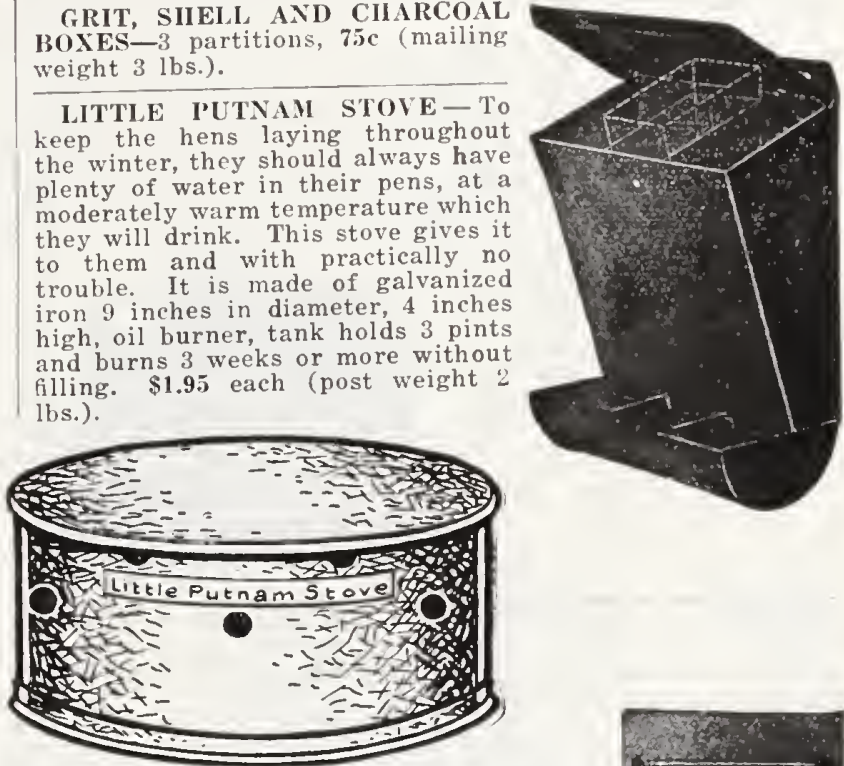

OAKES SINGLE FRONT FOR TRAP NEST-Makes a trap nest out of any ordinary box, practical but inexpensive. Each $35 \mathrm{c}$ (mailing weight 2 lbs.); per doz. $\$ 4.20$.
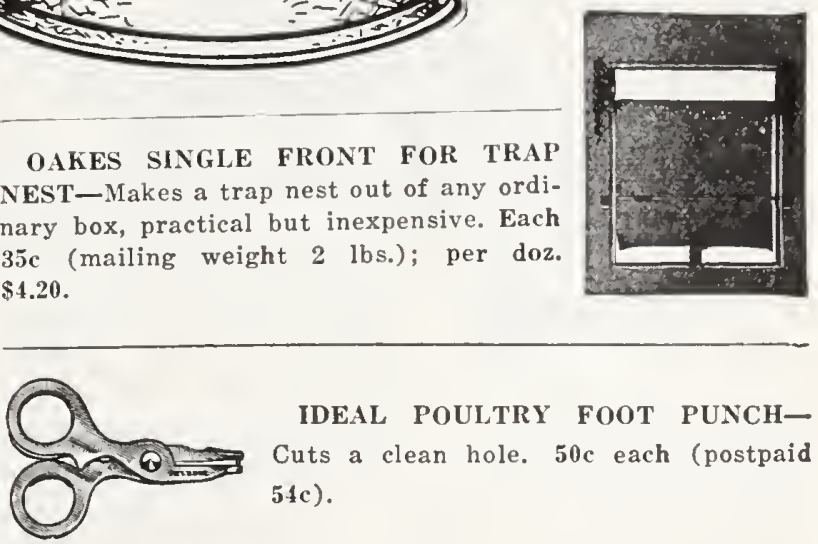

IDEAL POULTRY FOOT PUNCHCuts a clean hole. 50c each (postpaid 54c).

MOES TOE PUNCH-Each 25c; (postpaid 28c). 


\section{Egg Boxes}

METAL PARCEL POST EGG BOXES-A complete and substantial parcel post box for mailing Eggs and Butter; they

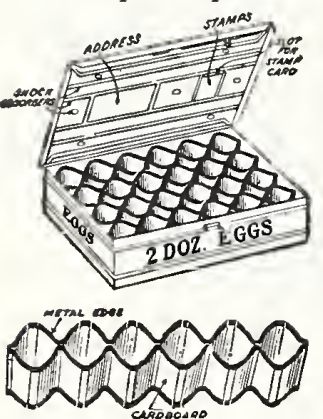

are well made of aluminized metal and can be used indefinitely. A space is provided on each box for reversible mailing address and stamps. Has hinge top and fastener. This is by far the best and most complete box manufactured for mailing eggs.

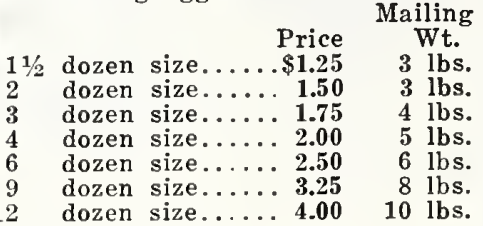

COMBINATION BOX-Holding 2 dozen eggs and 4 lbs. butter. $\$ 2.00$ (mailing weight $4 \mathrm{lbs}$.)

COMBINATION BOX-Holding 3 dozen eggs and 4 lbs. butter. \$2.25 (mailing weight 4 lbs.)

PARCEL POST EGG BOXES-Made of strong corrugated paper, will carry eggs safely by parcel post or express and can be used repeatedly.

1 dozen size (mailing weight 1 lb.).......\$.10

Doz.

2 dozen size (mailing weight 2 lbs.)..........13

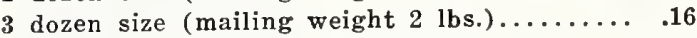

4 dozen size (mailing weight 3 lbs.)......... .20

5 dozen size (mailing weight 4 lbs.)..........25

$\$ .85$

1.50

1.75

2.00

2.50

HIUMPTY DUMPTY EGG CARRIER - Very popular crate for shipping and carrying eggs. Made of hardwood with wire rod fastened through the eorners. Has cardboard divisions and fillers. Safe, cheap and convenient.

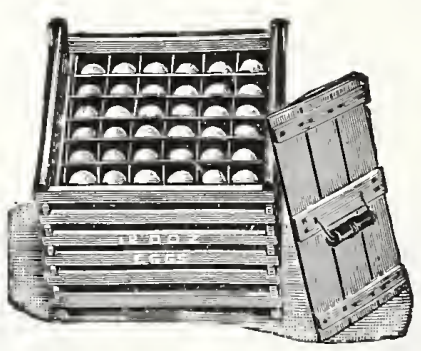

3 doz. size..\$ .35

6 doz. size.. .50

12 doz. size.. .60

15 doz. size.. .65

\section{Post}

Wt.

$4 \mathrm{lbs}$.

$5 \mathrm{lbs}$.

$7 \mathrm{lbs}$.

Cardboard and fillers, consisting of 6 each, fillers and flats, 20c per set. Mailing weight 3 lbs. per set.

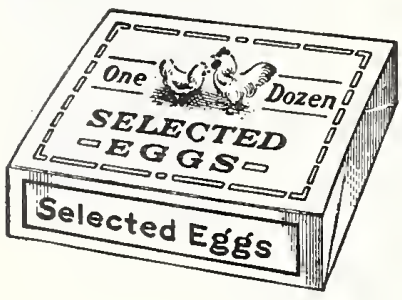

\section{PASTEBOARD EGG} CARTONS

Used for holding 1 dozen eggs, neatly packed for mar ket.

15c per doz.; $\$ 1.00$ per 100 ; $\$ 2.25$ per pkg. of 250 .

Mailing weight 2 lbs. to 1 dozen.

LIVE CHICK BOXES-For shipping live chicks. Ventilated, strong and durable. Comes in the knocked down. Easily clamped together.

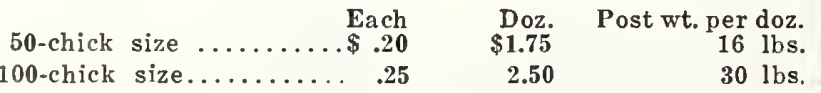

\section{Poultry Leg Bands}

When ordering Leg Bands, state what breed of fowl they are wanted for, and we will send the proper size.

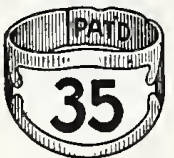

VICTOR-Made of aluminum. In colors with printed numbers; smooth finish; light weight; easy to put on and stays on. 12 for $50 \mathrm{c} ; 25$ for $\$ 1.00$ : 100 for $\$ 4.00$, postpaid.

RELIABLE-Made of aluminum with colored numbered inserts printed, adjustable, supplied in colors Red, White Blue, Yellow and Green and with numbers from 1 to 100 in all the colors. These are of smaller size and of lighter weight than the Victor Bands. 12 for 35 c; 25 for 65 c; 100 for $\$ 2.25$, postpaid.
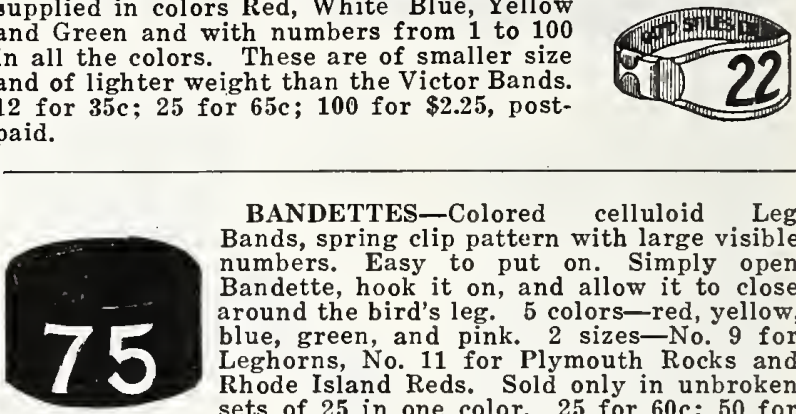

BANDETTES-Colored celluloid Leg Bands, spring clip pattern with large visible numbers. Easy to put on. Simply open Bandette, hook it on, and allow it to close around the bird's leg. 5 colors-red, yellow, blue, green, and pink. 2 sizes-No. 9 for Leghorns, No. 11 for Plymouth Rocks and Rhode Island Reds. Sold only in unbroken sets of 25 in one color. 25 for 60 c; 50 for $\$ 1.00 ; 100$ for $\$ 1.75$, postpaid.

FAVORITE-A popular aluminum band with raised figures. Can be supplied in consecutive numbers. Is easily attached. Cannot be lost off. Locks with a double clinch. 25 for $40 \mathrm{c}$; 50 for $65 \mathrm{c} ; 100$ for $\$ 1.00$, postpaid.
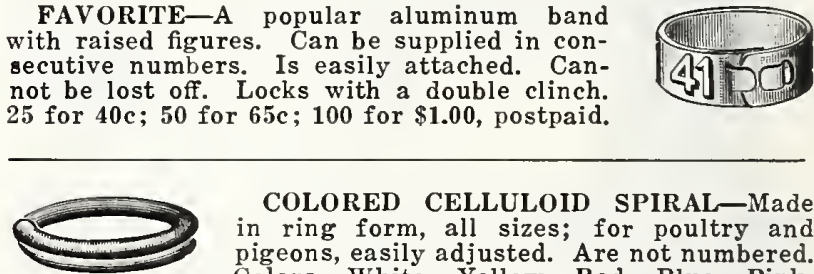

COLORED CELLULOID SPIRAL-Made in ring form, all sizes; for poultry and pigeons, easily adjusted. Are not numbered. Colors, White, Yellow, Red, Blue, Pink, Black and Green. 10c doz.; 50 for 35c; 60c per 100, postpaid.

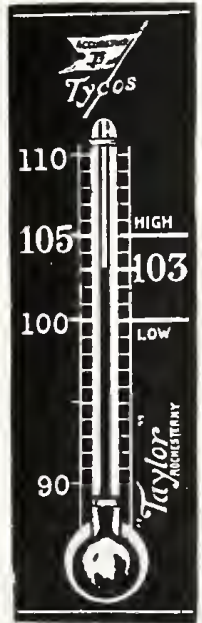

GRAIN SPROUTER-Is made in units of five individual pans, of galvanized steel, and a drip pan at the bottom. It sprouts oats quickly, ready to be fed to poultry in ten days.

5 pan, $11 \times 15 \ldots \ldots \ldots \ldots \$ 2.25$ (wt. 10 lbs.)

TYCO INCUBATOR THERMOMETERSAdjustable; can be used in any machine. Price 65c (postpaid $75 c$ ).

BROODER THERMOMETERS - Each 85c (postpaid 95c).

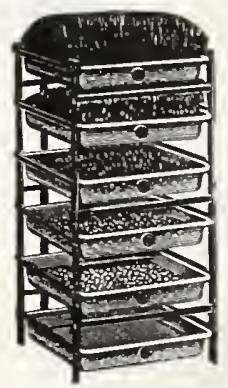

WHITE GLASS NEST EGGS-25c. doz. (mailing weight 2 lbs.).

LICE KILLING NEST EGGS-Shaped like a natural hen's eggs, but impregnated with lice killing and disinfecting properties, combining the qualities of a vermin killer and nest egg in one. Used to keep the nest sweet and clean and the fowls free from lice and disease. These should not be left in the nest with eggs over night, as the odor from these will sometimes taint the eggs. 6c each (mailing weight 4 ozs.): doz. 65c (mailing weight 2 lbs.). 


\section{SPRAYERS AND DUSTERS}

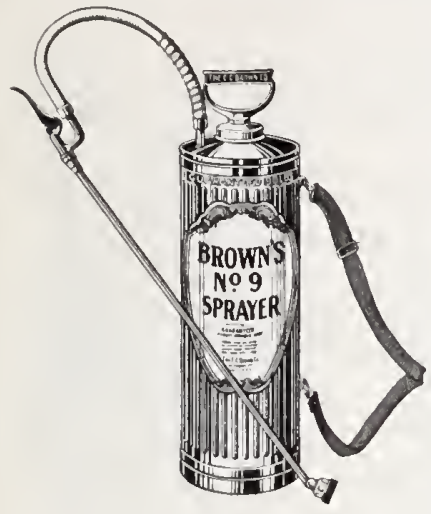

Nozzles for Auto Sprayers-60c each.

Nozzles for Whitewash Spraying-75c each.

AUTO SPRAY No. 6-A splendid brass bucket pump sprayer with 3 feet of hose; has two nozzles, one to be used when a single stream spray is desired, and one for a mist spray. The pump sprays on both the up and down stroke. Price \$4.25. Weight 7 lbs.

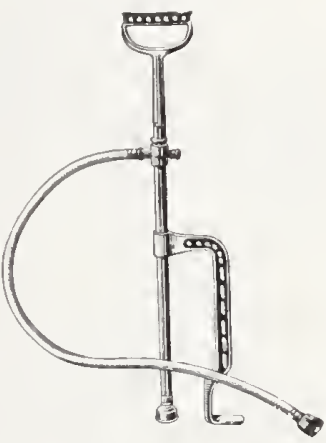

LITTLE GEM SPRAYERAn economical and handy sprayer for household use. Holds one pint. Price, 25c (postpaid 35c).
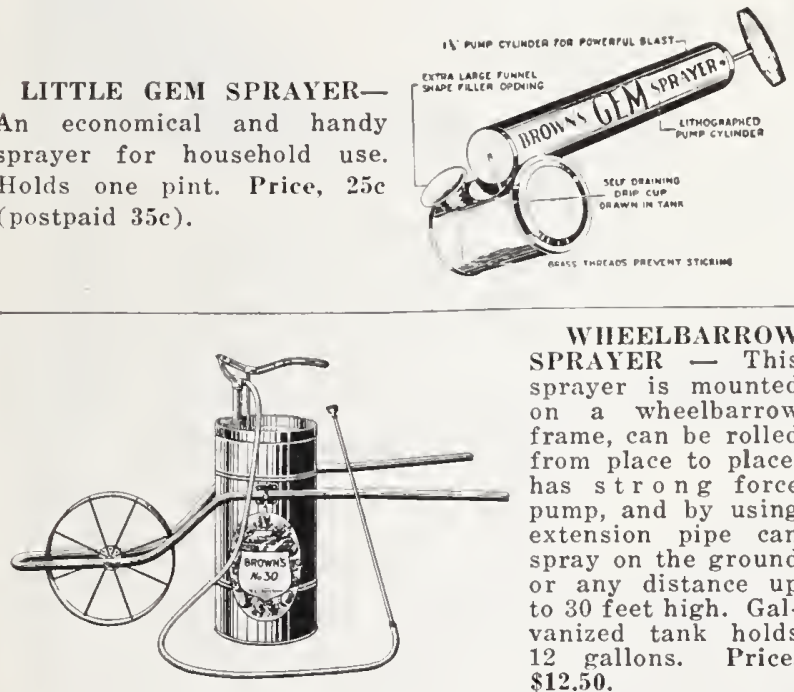

WHEELBARROW SPRAYER - This sprayer is mounted on a wheelbarrow frame, can be rolled from place to place, has $\mathrm{s} t \mathrm{r}$ ong force pump, and by using extension pipe can spray on the ground or any distance up to 30 feet high. Galvanized tank holds 12 gallons. Price, $\$ 12.50$.
PLATZ GREEN HAND DUSTER-This duster is operated by holding one handle in each hand and working same as an ordinary bellows. It is compact, sturdy, light and efficient. Has large powerful bellows. Easy to work and regulate. Excellent for dusting either hill crops or underside of foliage. Handles any dust. Holds 2 to 4 lbs. Has 30 inch extension with spreader. Weight $10 \mathrm{lbs}$. P'rice $\$ \mathbf{5 . 5 0}$.

BARREL I'UMP SPRAYER No, 40 -All working parts are brass, air tight and non-rusting. A large air chamber develops pressure to 300 lbs., with easy pumping. Fits barlel of any height. Sprays anything. An excellent Barrel Pump Sprayer complete with $12 \frac{1}{2}$ feet of hose and nozzle. (Without barlel) price $\$ 13.50$.

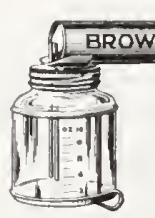

\section{S TWIN BLAST}

TWIN BLAST-One of the best single action Sprayers. Equipped with twin spray jets which diffuse a large volume of fine misty spray. Has Glass Tank. Easily cleaned. Sprays different solutions. Holds 1 quart, $75 \mathrm{c}$ (postpaid 850 ).

\section{CRYSTAL DUSTER}

- This is one of the newest type Dusters for applying powder pois on. Especially good for applying poison for the Bean

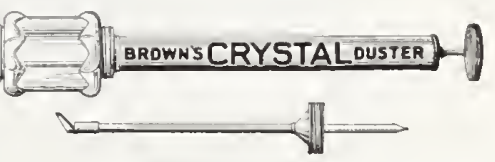
Beetle, as it is equipped with an extension and adjustable nozzle. It enables the operator to dust underneath the plant leaves without bending. The nozzle being adjustable can dust straight down as may be desired. Has one quart glass container. $\$ 1.25$ (postpaid \$1.35).

\section{CARBOLA-Is a} splendid germ killpowdered for m, disinfectant many $t$ i $m$ es stronger than pure carbolic acid. It is non-poisonous and noncaustic. It $\mathrm{k}$ ill $\mathrm{s}$ lice, mites, fly eggs, etc., and helps prevent the start and spread of contagi-

ous diseases that affect man, beast and fowl. Carbola is two things in one-a paint that disinfects or a disinfectant that paints. It dries a clear snow white. It saves labor, time and money. It paints and disinfects at one operation in the same time and with the same labor required to paint or disinfect only. Pamphlet on request. 5-1b. pkg. 75c; 10 lbs. $\$ 1.25 ; 50$ lbs. $\$ 4.50$. Postage extra if mailed.

\section{Fruit Trees and Evergreens}

We are the authorized agents for the Elmwood Nurseries and will be glad to send on request complete descriptive Catalogue to those interested in Fruit Trees, Berry Plants, Evergreens, an'd all Nursery Stock. 
We have carefully considered the needs of our customers in making up our list of Fertilizers, and in the following list will be found brands with balanced analysis to meet the needs and requirements of the most exacting grower, whether he raises Vegetables for market or home use, grows Tobacco, Peanuts or Grain and Grass crops.

We have received many testimonials from our customers who have used these Fertilizers year after year with most satisfactory results.

We recommend the use of the higher grade Fertilizers, as experience has proven that the high-grade fertilizers are much more economical to use than the lower grade goods at cheaper prices, as the cost of bags, labor, freight, drayage, storage, and other items of expense is the same per ton on low-grade goods as on the higher grades. Truckers and farmers now realize this and the demand for higher grade goods is increasing with each season.

Prices of Fertilizers given below are the prices in effect at the time this catalogue goes to press in December. These prices are subject to change and should there be any change such changes will be noted in our Current Price List.

\section{D. \& B.'s Earliest Truck Grower}

In this brand we have an excellent well balanced Fertilizer for use on early truck crops, such as Cabbage, Potatoes, Beets and other Vegetables for extra early use. It is also a splendid Fertilizer for top dressing. For the convenience of the small gardener we are offering this brand in small packages.

Analysis

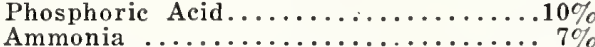

Potash ..............

5-1b. pkg. 30c; 10 lbs. 50c; 25 lbs. \$1.00; 50 lbs. \$1.50; 100 lbs. $\$ 2.50$; per ton $\$ 38.00$.

D. \& B.'s Potato and Berry Grower

In this brand we have a complete, well-balanced fertilizer for both Irish and Sweet potatoes and berries. It is recommended for either early or late potatoes. It has just the required nitrogen to force the growth and make vigorous vines, and a larger per cent of potash to mature the crop. We also recommend it highly for top-dressing berries in the spring. It will produce a good growth of vines and greatly increase the yield of berries. Because of the excellent results obtained from its use this brand is growing in popularity each year.

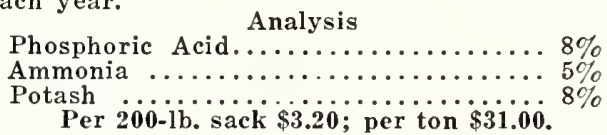

\section{D. \& B.'s Vine and Vegetable Grower}

This is a complete Fertilizer for Vegetables and all other vine and crops requiring a liberal quantity of Potash. We also recommend this Brand for use on Cotton and Tobacco, as it contains just the proper proportions of Plant Food for these crops, and a better Fertilizer for this purpose cannot be had at this price. Many of our customers also use this Brand on late Irish Potatoes with good results. We have sold this Brand for years and it has given excellent results wherever used. Our customers, who use this brand, are enthusiastic in their praise of it.

Analysis

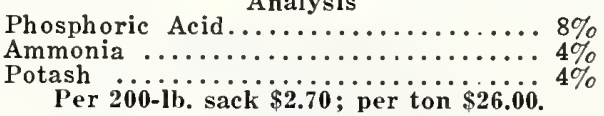

\section{D. \& B.'s Garden and Lawn Enricher}

Strictly an Organic Manure entirely free from all chemicals.

This brand is made entirely from animal and vegetable matter. It is composed of Sheep Manure, Poultry Manure, Pure Raw Bone Meal and Pulverized Tobacco Stems. It is a complete, well-balanced manure blended in the proper proportions to give the best results when used on gardens, lawn, golf courses, shrubs, evergreens, fruit trees, and other plants. It is far more lasting in its effect than chemical fertilizers; contains no weed seeds. Analysis

Phosphoric Acid................. $71 / 2 \%$

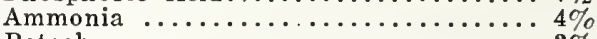

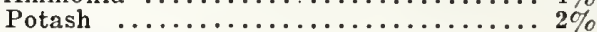

5 lbs. 30c; 10 lbs. 50c; 25 lbs. $\$ 1.00 ; 50$ lbs. $\$ 1.75$; 100 lbs. $\$ 3.00 ;$ per ton $\$ 50.00$.

\section{D. \& B.'s Garden and Potato Grower}

We have had this high-grade fertilizer manufactured especially for early Garden Vegetables and Irish Potatoes; it is a complete and well balanced Fertilizer for all of these crops.

Analysis

Phosphoric Acid................ $8 \%$

Ammonia .................... 5\%

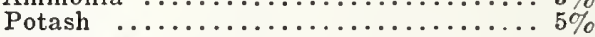

Per $100-1 b$. sack $\$ 1.75$; per 200 -lb. sack $\$ 2.90$; per ton $\$ 28.00$.

\section{D. \& B.'s Corn and Grain Grower}

A well balanced Fertilizer, especially recommend for Corn and all Grain crops, Cow Peas, Millets, Fodder Plants, etc.

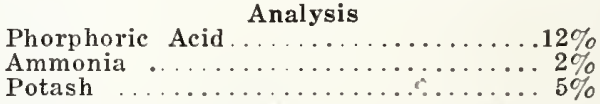

Per 200-1b. sack \$2.50; per ton $\$ 24.00$.

\section{Super Phosphate 16 Per Cent}

Formerly called Acid Phosphate.

This is very beneficial for nearly all soils; many of our customers make excellent Grass Crops with Super Phosphate. Per 200-lb. sack $\$ 1.50$; per ton $\$ 14.00$.

\section{Sulphate of Ammonia}

This is the most concentrated form of Nitrogen obtainable. It is guaranteed $251 / 4$ per cent Ammonia equivalent to Nitrogen $20 \%$ per cent. In this product Nitrogen costs less per unit than in any other form. It is quickly available, but not readily leached from the soil. This article is in excellent mechanical condition. It is fine and dry and easily applied. The crop-producing power of Sulphate of Ammonia is equal to that of any fertilizer material and is more lasting in its effect than Nitrogen applied in other forms. This is the fertilizer to make quick truck crops and for top dressing grass and grain crops. It has no odor, is soluble, the effect can be seen a few days after applying. It is unequalled for shrubs and flowers. Checks weeds and makes a wonderful velvety lawn. 2-lb. pkg. 15c; 5 lbs. 30c; 10 lbs. $50 \mathrm{c} ; 25$ lbs. $\$ 1.00 ; 50$ lbs. $\$ 1.50 ; 100$ lbs. $\$ 2.50$; ton $\$ 40.00$

\section{B. B. B.}

This popular and well-known brand of Fertilizer is especially recommended for Corn, Field Peas, Beans, Millets, Oats, and Fodder Plants. Analysis:

Phosphoric Acid..............8\%

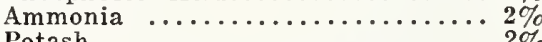

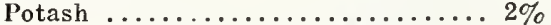
Price on Application.

\section{Nitrate of Soda}

Largely used to produce a quick growth, especially in Garden Crops, bringing them on very rapidly, but it is of no permanent value as a Fertilizer. Also used to stimulate the growth of grass in the spring and as a top dressing for Vegetables, but it should be used very lightly, not over 100 pounds to the acre. Our Nitrate is thoroughly reground and in splendid mechanical condition for applying. Price fluctuates.

Present Prices-Per lb. 10c; 5 lbs. 30c; 25 lbs. $\$ 1.00 ; 100$ lbs. $\$ 2.50$; per ton $\$ 40.00$.
Prepared Agricultural Lime

This Lime is very valuable for use on Alfalfa and all other grass and grain crops. It corrects acidity in the soil, deconposes vegetation quickly, loosens up heavy stiff lands, binds together light sandy soils, makes available dormant plant food, phosphoric acid and potash. Much less is required per acre than burnt rock lime and limestone, and much better results are obtained from its use, as this lime contains 4 per cent of potash. It is a valuable fertilizer, as well as a sweetener of the soil.

Per 200-lb. sack $\$ 1.40$; per ton $\$ 13.00$. If a car load lot is wanted write us for a special price delivered your station.

\section{Agricultural Burnt Lime}

Valuable for applying on Clover and Grass crops. Particularly valusble to be used when preparing land for Alfalfa. Per 80 -1b. sack 75c; per ton $\$ 12.50$. 


\section{V-C FAIRWAY FERTILIZER}

FOR LAWNS AND GRASS

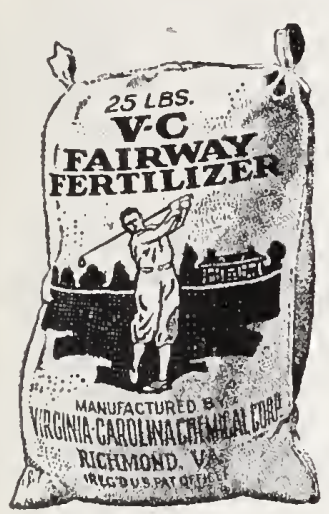

To have a lawn of closer, fastergrowing grass that resists drouth, stays greener-constantly thickens and spreads-use V-C Fairway Fertilizer.

This is the treatment now used on the lawns of country estates, polo fields and on the most famous golf courses.

Fifteen times as rich as manure; costs not more than 10 cents for each 100 square feet to be treated. Practically no odor.

Prices-100-lb. bag (enough for 5,000 sq. ft.,$\$ 5.00 ; 50-1 b$. bag (enough for 2,500 sq. ft.), $\$ 3.00$; 25-lb. bag (enough for $1,250 \mathrm{sq}$. ft.), $\$ 1.75 ; 10$-lb. bag (enough for 25 sq. ft.), 85c. Convenient, easy to handle. Complete directions for lawn treatment on every bag.

\section{BLOOMAID}

FOR FLOWERS, SHRUBS, VEGETABLES

If you want your flowers to bloom earlier and longer, your shrubs and hedges to be greener, thriftier, we recommend that you use Bloomaid. Makes plants double the size of those not treated.

Use it in the vegetable garden, around shrubs and to enrich the soil in window boxes and flower pots.

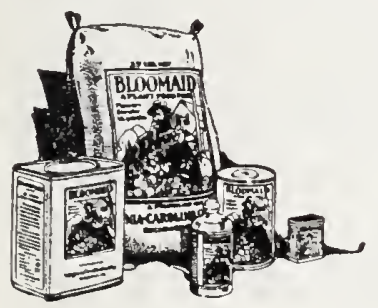

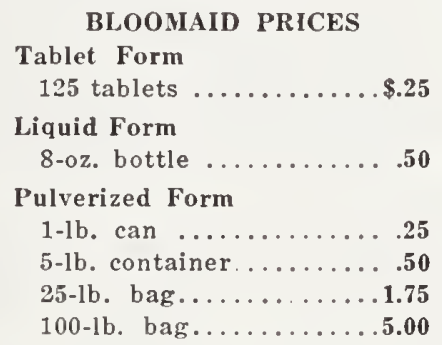

\section{PULVERIZED SHEEP MANURE}

This is the pure, natural manure saved from the stock yards, is thoroughly dried, pulverized and screened; is light and easily and quickly applied. It is free from weed seeds and a splendid fertilizing manure for all crops and especially for top dressing lawns and golf courses, shrubs and vegetables, also flowers and house plants.

For Lawns, Golf Courses, Country Greens and FairwaysIt promotes strong, healthy growth and a bright green velvety turf. 10 pounds for each 100 square feet should be worked into the soil before seeding, or scatter broadcast over an old lawn, and wet down. No weeds. No litterquick and pleasing results are certain.

For Flowers, Shrubs, Vines, Trees, Etc.-1 pound for each 10 square feet of surface well mixed into the soil before planting, and 1 to 10 pounds dug in around vines, shrubs, trees, etc., is sufficient. Vary the quantity depending on size and root development. The effect will show in a few days. 50-lb. bag $\$ 1.25 ; 100$-lb. bag $\$ 2.25$; ton $\$ 41.00$.

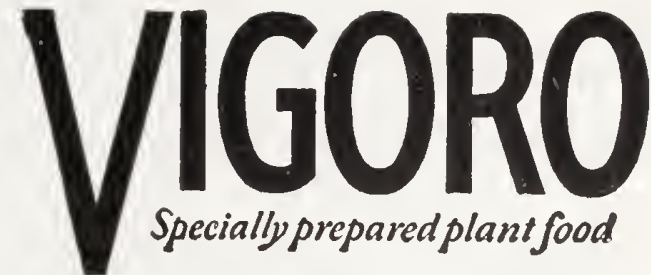

Scientifically prepared by Swift \& Co. for use on Lawns, Flowers, Shrubs and Vegetables. Clean, odorless and easy to use. 5 lbs. 50c; 25 lbs. $\$ 1.75 ; 50$ lbs. $\$ 3.00 ; 100$ lbs. $\$ 5.00$.

\section{PURE RAW BONE MEAL}

This Bone is largely used on Grain and Grass crops, also gives excellent results if used when seeding a lawn. Is also very beneficial for top dressing lawns already established. It is in fine mechanical condition, drills perfectly, and is easily applied.

Analysis
Phosphoric Acid ..........21 $1 \frac{1}{2}$ per cent

Ammonia .............4 4 $1 / 2$ per cent

50 lbs. $\$ 1.25 ; 100$ lbs. $\$ 2.25 ; 200$-lb. sack $\$ 3.80$; per ton $\$ 37.00$.

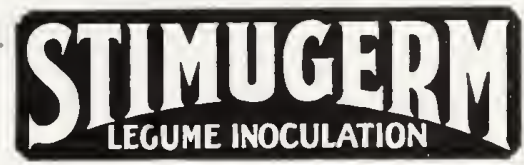

INCREASES CROP PRODUCTION AND GREATLY IMPROVES THE SOIL

All legumes (pod bearing) crops, such as clovers, alfalfa, beans, peas, vetch, soybeans, cowpeas, peanuts, etc., will yield far better crops if the seeds are inoculated with Stimugerm, and will leave in the soil a heavy deposit of nitrogen for the benefit of succeeding crops.

The method of inoculating the seed with Stimugerm is very simple; anyone can use it. Simply add water to the culture, $\mathrm{sh}$ a ke well and pour the mixture ove $r$ the seed, spread them out to dry. They are then ready to sow. Complete directions are $\mathrm{sen} \mathrm{t}$ with each bottle.

In ordering be sure to state the exact kind of legume crop that you intend to inoculate, as each kind of legume requires a

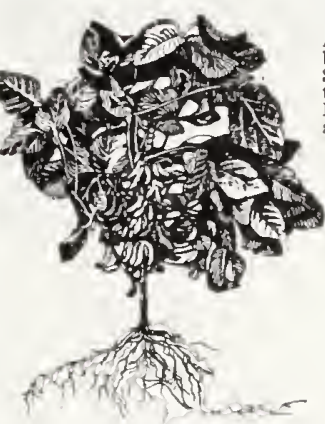
Sotice how much blgger inoculated Soy Beans may grow than uninoculated. Drawing made from otorraph. different kind of culture.

\section{IT PAYS TO INOCULATE WITH STIMUGERM}

SMALL SEED LEGUME

VARIETIES-Alfalfa, Clovers, Sweet Clovers

$1 / 6$ bu. size..........\$.35

$1 / 2$ bu. size...........60

1 bu. size............1.00

$21 / 2$ bu. size............2.

10 bu. size.........8.00
LARGE SEED LEGUME VARIETIES-Soy Beans, Cow Peas, Vetch, Peas

$1 / 2$ bu. size........\$.35

1 bu. size..........60

2 bu. size..........1.10

5 bu. size.........2.25 


\section{SPRAYING GUIDE}

Thls condensed spraylng calendar has been carefully prepared and will be found very valuable to fruit growers as it shows at a glance how to spray intelligently for the various Insect pests and fungus diseases to which fruit trees are subjected.

\begin{tabular}{|c|c|c|c|c|}
\hline$\underset{\text { Fruit }}{\text { Find of }}$ & Kind of Pest & What to Use & *Dilution & $\begin{array}{c}\text { When to spray. (1) Means first spray. (2) Means second } \\
\text { spray, and so on. }\end{array}$ \\
\hline \multirow{6}{*}{ APPLE } & San Jose Scale........ & Scalecide $\ldots \ldots \ldots \ldots$ & 7 gals......... & (1) Just before blossoms in cluster bud. (2) At fall of blossoms. \\
\hline & Codling moth......... & $\overline{\text { Dry Arsenate of lead. }}$ & 2 to 3 lbs... & $\begin{array}{l}\text { (1) At fall of the blossoms before the calyx closes. (2) Three } \\
\text { weeks after fall of blossoms. (3) Ten weeks after fall of } \\
\text { blossoms. (4) Fourteen weeks after fall of blossoms. (5) } \\
\text { Seventeen weeks after fall of blossoms. }\end{array}$ \\
\hline & Cankerworm........... & Dry Arsenate of lead. & 2 to 4 lbs... & (1) Just before blossoms in cluster bud. (2) at fall of blossoms. \\
\hline & Bitter-rot............. & Dry bordeaux......... & $18 \mathrm{lbs} \ldots \ldots$ & $\begin{array}{l}\text { Spray about the middle of June and keep fruit coated the } \\
\text { rest of the season. }\end{array}$ \\
\hline & Blotch........... & $\begin{array}{l}\text { Dry lime sulphur...... } \\
\text { Dry bordeaux....... }\end{array}$ & $\begin{array}{r}6 \mathrm{lbs} . \mathrm{i} \ldots . . \\
14 \text { to } 18 \mathrm{ibs} .\end{array}$ & $\begin{array}{l}\text { (1) Three weeks after fall of blossoms. (2) Five weeks after } \\
\text { fall of blossoms. }\end{array}$ \\
\hline & Scab............ & $\overline{\text { Dry lime and sulphur }}$ & 6 to $8 \mathrm{lbs} .$. & $\begin{array}{l}\text { (1) Just before blossoms in cluster bud. (2) At fall of blos- } \\
\text { soms. (3) Within a week or ten days later. (4) Latter } \\
\text { part of July if weather is cool and wet. }\end{array}$ \\
\hline \multirow{5}{*}{ PEACH } & Peach twig borer..... & Dry lime: & $25 \mathrm{lbs} \ldots \ldots \ldots$ & Just after buds begin to swell. \\
\hline & Curculio........ & $\begin{array}{l}\text { Dry arsenate } \\
\text { and Lime. }\end{array}$ & $\begin{array}{l}2 \text { to } 3 \mathrm{lbs} . \\
6 \mathrm{lbs} . \ldots \ldots\end{array}$ & $\begin{array}{l}\text { (1) When first shucks are pushing off. (2) Again when all } \\
\text { shucks are off. (3) Three or four weeks after fail of blos- } \\
\text { soms. }\end{array}$ \\
\hline & Brown rot............ & Dry lime sulphur.... & 10 to $15 \mathrm{lbs} .$. & $\begin{array}{l}\text { (1) When all shucks are off. (2) Three or four weeks after } \\
\text { fall of blossoms. (3) Four weeks before fruit is ripe. Should } \\
\text { weather be damp and warm near ripening time keep fruit } \\
\text { well coated with spray. }\end{array}$ \\
\hline & 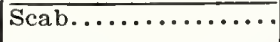 & Dry lime sulphur .... & 25 to $30 \mathrm{lbs} . .$. & Spraying for brown rot controls scab. \\
\hline & eaf curl........ & Scalecide & 7 gals........ & Either in fall after leaves drop or in spring before buds swell. \\
\hline \multirow{4}{*}{ PEAR } & & Dry Arsena & 2 lbs......... & When slugs appear. \\
\hline & Pear & Dry lime suil & 25 to $30 \mathrm{lbs} \ldots$ & When cluster buds are separating at tips. \\
\hline & Pear leaf blister mite & Dry lime sulp & 25 to $30 \mathrm{lbs} .$. & In fall after leaves drop or in the spring before buds burst. \\
\hline & Scab................. & $\begin{array}{l}\text { Dry lim } \\
\text { Dry bor }\end{array}$ & $\begin{aligned} & 6 \text { to } 8 \text { lbs... } \\
& 18 \text { lbs.......... }\end{aligned}$ & $\begin{array}{l}\text { (1) Just before bloom, cluster bud. (2)At fall of blossoms, } \\
\text { (3) Two weeks later. }\end{array}$ \\
\hline \multirow{3}{*}{ DLUM } & Curculio. & Dry Arsenate of lead. & $2 \mathrm{lbs} \ldots \ldots$ & $\begin{array}{l}\text { (1) Just before blossom buds open. (2) At fall of blossoms. } \\
\text { (3) A week later. }\end{array}$ \\
\hline & Brown Rot........... & Dry lime sulphur. & 2 to $3 \mathrm{lbs} .$. & $\begin{array}{l}\text { Just before buds open. (2) Immediately after blossoms } \\
\text { fall. (3) Ten days to two weeks later. If season is wet. } \\
\text { spray every two weeks until month before picking time. }\end{array}$ \\
\hline & Leaf Spot............ & Dry lime sulphur..... & 2 to $3 \mathrm{lbs}$. & $\begin{array}{l}\text { (1) Ten days after fall of blossoms. (2) Three weeks later, } \\
\text { (3) Six weeks after fall of blossoms. }\end{array}$ \\
\hline \multirow{3}{*}{ CHERRY } & Cherry Slug.... & Dry Arsenat & 2 to $3 \mathrm{lbs} \ldots$ & When slugs appear. \\
\hline & Brown Rot.... & Dry lime sulphur..... & 2 to 3 lbs.. & $\begin{array}{l}\text { (1) Just before the blossoms. (2) At fall of blossoms. (3) } \\
\text { A week to ten days later. (4) When fruit begins to color. }\end{array}$ \\
\hline & Curculio.............. & Dry Arsenate of lead. & 2 to $3 \mathrm{lbs}$. & (1) At fall of blossoms. (2) A. week to ten days later. \\
\hline \multirow{3}{*}{ GRAPE } & Rose Chafer... & $\begin{array}{l}\text { Dry Arsenate of lead. } \\
\text { and Molasses. }\end{array}$ & 4 lbs.; 2 gal. & $\begin{array}{l}\text { At first appearance of beetles and one week later if beetles } \\
\text { are still present. }\end{array}$ \\
\hline & Grape Berry Moth... & Dry Arsenate of lead. & $3 \mathrm{lbs} . . . \ldots \ldots$ & (1) Just before fruit sets. (2) About 10 days later. (3)Mid-July. \\
\hline & Black Rot............ & Dry bordeaux......... & 14 to $18 \mathrm{lbs} .$. & $\begin{array}{l}\text { (1) When second or third leaf is showing. (2) Before the } \\
\text { blossoms open. (3) After fall of blossoms. (4) About ten } \\
\text { days to two weeks later. (5) Again in ten to fourteen days. }\end{array}$ \\
\hline
\end{tabular}

*All dilutions to be made on the following basis to the 100 gallons of spray.

Approximate Quantities of Diluted Spray Solution Required for Thorough Spraying The quantity will vary of course according to the slze of the tree and whether or not tree Is dormant, in blossom or in full leaf.

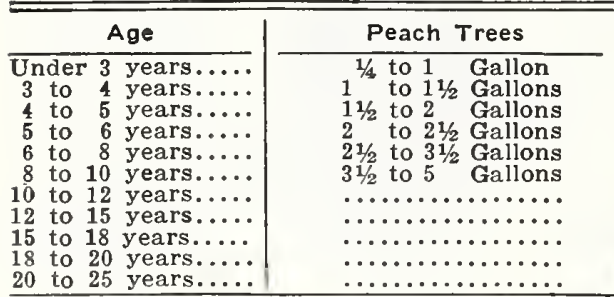

20 to 25 years......

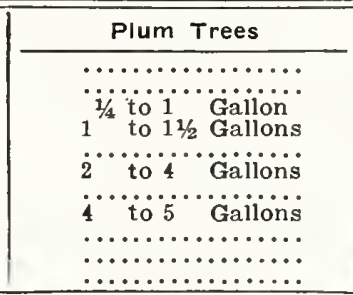

INDEX

Page

Artichoke $. . . \cdots \cdots \ldots . .48$

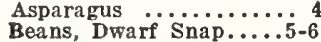

Beans, Pole Snap.......6 6

Beans, Llma.........6-7

Beans, soy............

Beans, velvet............47

Bee Supplies..............

Bee Supplies...............

Beets $\ldots \ldots \ldots \ldots \ldots \ldots \ldots$ 8

Broccoli

Broom Corn.............48

Buckwheat ...........48

Bulbs $\ldots$..............40-41

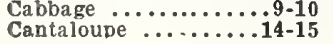

Carrot .............. Page

Caulifiower $\ldots . . . \ldots \ldots \ldots . . .1 \%$

Carbola ..................

Collards

Celery ...............10-11

Chlcks, Baby...........55

Corn, Garden..........11-1

Corn, Fleld..........45-46

Cucumber $\ldots \ldots \ldots \ldots \ldots \ldots$
Clovers $\ldots \ldots \ldots \ldots$

Clovers $\ldots . . . \ldots \ldots \ldots \ldots . .64$

Ducklings $\ldots \ldots \ldots \ldots \ldots \ldots . . .65$

Egg Plant..............

Endive $\ldots \ldots \ldots \ldots \ldots \ldots \ldots \ldots \ldots$

Flower Seeds.........30-38

Flower Pots...........60
Frult Baskets ..... Page

Grass Seeds.............243

Garden Tools and

Supplles ...........50-51

Herbs $\ldots \ldots \ldots \ldots \ldots \ldots \ldots \ldots \ldots \ldots$

Hotkaps ...............55

Incubators and Brooders..55

Inriculating Cultures....61

Kaffr Corn...............

Kale............ i7 and 48

Kohl Rabi.................

Leek .................12

Lettuce .................18

Millet .................48

Mulch Paper...............

Mustard ...............
Apple Trees

$\begin{array}{lll}\text { i.4 to } 1 & \text { Gallon } \\ 1 & \text { to } 2 & \text { Gallons } \\ 2 & \text { to } 3 & \text { Gallons } \\ 21 / 2 & \text { to } 31 / 2 & \text { Gallons } \\ 3 & \text { to } 4 & \text { Gallons } \\ 31 / 2 & \text { to } 4 & \text { Gallons } \\ 4 & \text { to } 5 & \text { Gallons } \\ 41 / 2 & \text { to } 51 / 2 & \text { Gallons } \\ 5 & \text { to } 6 & \text { Gallons } \\ 6 & \text { to } 8 & \text { Gallons }\end{array}$

$\mid$

Pear Trees

ii to "is Gallon

$1 / 2$ to $1 / 2$ Gallon

1 to $11 / 2$ Gallons

$11 / 2$ to 2 Gallons

2 to $21 / 2$ Gallons

3 to $31 / 2$ Gallons

$31 / 2$ Gallons

$\begin{array}{lll}31 / 2 & \text { to } 5 & \text { Gallons } \\ 5 & \text { to } 8 & \text { Gallons }\end{array}$

$=$




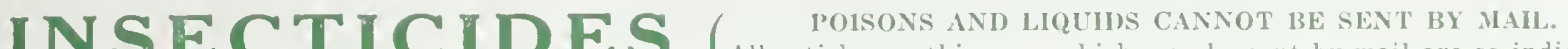

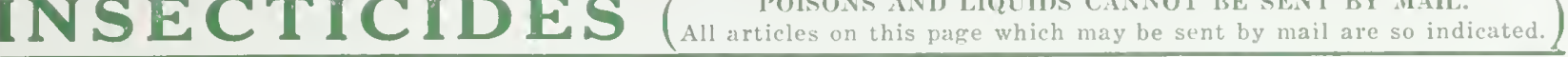

LIME-SULPHUR (l'owdered)-Used for spraying fruit trees and all nursery stock. For destroying San Jose Scale and other diseases and insects. This preparation has all the advantages of the liquid material, but eliminates the disadvantages and is less expensive. For dormant spraying use 1 lb. to 5 gallons of water; for summer spraying $1 \mathrm{lb}$. to 20 gallons of water. Full directions for applying with each package. Prices on application.

DRY BORDEAUX MIXTURE-This is a true Bordeaux Mixture in dry powdered form, requiring only to be mixed with cold water to give a standard Bordeaux Mixture Spray for fruit trees, shrubs, vegetables, etc. The convenience and value of having Bordeaux in dry powdered form will be instantly appreciated by all fruit growers. It is also less expensive than the liquid Bordeaux. Complete directions and moportions to be diluted with each package. Prices on application.

SCALLCIDE-Is a complete preparation for dormant spray. ing, used for the destruction of San Jose Scale, Bud Moth, Leaf Curl, Fungus Cankers, and in fact all the various insect pests and fungus diseases to which fruit trees are subjected and in addition the use of Scalecide yaar after year invigorates the trees. This preparation is perhaps the best known and is widely advertised. Orchardists throughout the country use it effectively in very large quantities. Dilute Scalecide at the rate of 1 gallon to 15 gallons of water. It is pleasant to use and it does not clog nozzles. hose or pump. Trees may be sprayed in winter or early spring before they start to come into bud. Qt. $70 \mathrm{c} ; 1$ gal. $\$ 1.60 ; 5$ gals. $\$ 6.00 ; 10$ gals. $\$ 10.00 ; 15$-qal. drum $\$ 13.50$ : 30 gals. $\$ 2.1 .50 ; 50$ gals. $\$ 34.00$. Write for delivered price in large quantities. Camnot mail.

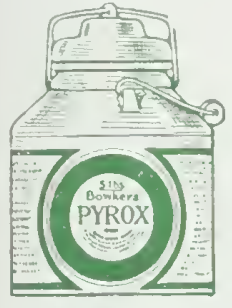

p) $\operatorname{ROX}$ is a powerful fungricide and most effective remedy for blight and all fungus diseases; a strong poison insecticidle; kills all chewing insects; increases yield of fruit and promotes a healthy and vigorous vine and lcaf. Recommended for use on fruit (with exception of peaches). regctables, berries, etc. Is easy to apply. Simply mix with cold water and spray. It sticks like paint and stays on for weeks. To be used about 1 lb. to 6 gallons of watel, according to fruit to be sprayed. (omplete directions with each package. Cannot mail.

1RI30 Is a combined insecticide and fungi cide which prevents certain fungus diseases and kills most leaf eating insects at one spraty. It has the fungrcide qualities of Bordeaux and the killing values of l'aris Green and Arsenate of Learl in one inixture. It is made ready for use by mixing with cold water. For general use 1 lb. to 5 gallons of water is sufficient. Full directions with each package. Cannot mail.

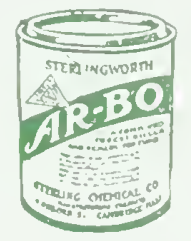

S. $B A G$ BLCS:AND BLICHT, NONDSS SLUGS

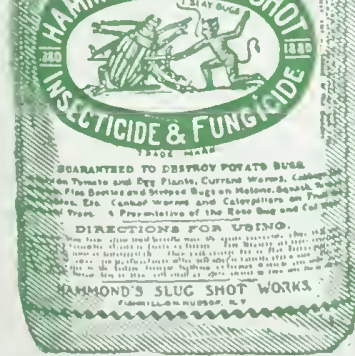

IIAMMONI'S SLLG S11OT A very effective insect destroyer and one of the best powders for destroying bugs and other insects on all vine and garden crops. It comes ready for use and is generally applied dry, but can be used in water. 1 lb. filled canister, with perforated top ready for dusting, $20 \mathrm{c}$ each (postpaid 30c); 5-lb. plig. 550 (postpaid 70c); $50 \mathrm{Ibs}$. $\$ 5.00$.

EVERGREEN-A most effective insecticide for destroying the Bean Beetle and all other chewing and sucking insects. ()x. bottle $35 \mathrm{c}$ (postpaid $10 \mathrm{c}$ ) 6 oz. $\$ 1.00$ (postpaid $\$ 1.10$ ) 16 oz. $\$ 2.00$ (postpaid $\$ 2.15$ ).
DRY POWDERED ARSENATE OF LEAD-For destroying leaf-eating insects. Should be mixed thoroughly with a small quantity of water to a creamy consistency, then add the required amount of water according to directions on each package. Cannot mail.

CALCIUM ARSENATE-For destroying leaf eating inseets. Can be diluted and applied with a dry power gun or spray
bump, does not burn the foliage and sticks well to the leaf. ainnot mail.

TUBE1R 'TON1C-A dry powdered combination Potato spray, is valuable for destroying Potato Bugs and similar insects as well as a preventive of blight. To be diluted in water. Full directions with each package. Postage cxtra if mailed.

INSECTO-This is a composition of Arsenate of Lead and Bordeaux Mixture materials in a dry powdered form, to be diluted with water and used as a eombination insectieide and fungicicle for fruit trees and garden slraying. Cannot mail.

PARIS GREEN-Is effective for destroying potato bugs, tobacco worms and other insects. Is a very strong poiron, and should be used carefully. Mix $1 \mathrm{lb}$. Paris Green to 150 gallons of water. ('annot mail.

SULPHUR-Recommended to be used on Irish Potato tubers when planting, at the rate of about $1 \mathrm{lb}$. of Sulphur to 60 lbs, of Potatoes, it prevents the bleeding of Potatoes and is also a preventive of scab. Per lh. 10 c; 10 lbs. 75e; 25 Ibs. $\$ 1.65 ; 100$ lbs. $\$ 5.50$; harrel 250 Ibs. $\$ 13.50$. Postage extra if mailed.

BLACK LEAF 40-A solution of Nicotine and Sulphate containing 40 per cent nicotine. This is the insecticide so highly recommended by the experimental stations as a spray for all soft-bodied sucking insects and without injury to the foliage. It may be combined with other sprays if desired; is highly concentrated; soluble in water, easy to mix, and does not clog nozzles. 1 oz. 35 c, makes 6 gallons of spray; 5 oz $\$ 1.00$, makes 40 to 120 ralloms of spray; i lb. $\$ 2.50$ nakes 80 to 240 gallons of spray; $21 \mathrm{lbs} . \$ 3.75 ; 5$ lbs. $\$ 7.00$; 10 lbs. \$11.5.5.

TREE TANGLEFOOT-A sticky preparation used for smearing on the trunks of trees as a safeguard against eaterpillars, moths, ants and other creeping insects. Full directions on each package. (Postage extra if mailed.

COPPER CARBONATE-A dry powder used for applying on Seed Wheat and other grains to prevent smut and other diseases.

PESTRol-Pestroy is a combined insecticide and fungicide rspecially adaptesl for use in the home garden. It is designed for the control of many chewing insects and fun gous diseases, containing the proper propontion of Arsenate combat the latter.

SEIESAN A thercuric disinfectant put up by the Du Pont Company to control or prevent Seed, Mlant, and Soil diseases. It destroys most of the fungus and bacterial diseases car ried on the surface of seeds or plants, as well as some of those which infest the soil. It also hastens germination, invigorates seedling growth, produces sturdier plants and increases crop vields. Booklet giving complete information on request. 2-0z. bottle $50 \mathrm{c} ; 1-1 \mathrm{~b}$. tin $\$ 2.75$. Cannot mail.

SEMESAN JR.-A dust disinfectant for Seed Corn. 1-ll), tin $\$ 1.75$. Cannot mail.

SEMESAN BEL-An instantaneous dip disinfectant for Seed Potatoes. 5-1b. tin $\$ 8.00$. Cannot mail.

Market ('banges on Insecticides makes it impossible to quote prices in our catalogue. T'herefore we quote prices on application only. 


\section{SOW DIGGS \& BEADLES TESTED SEEDS 1932}

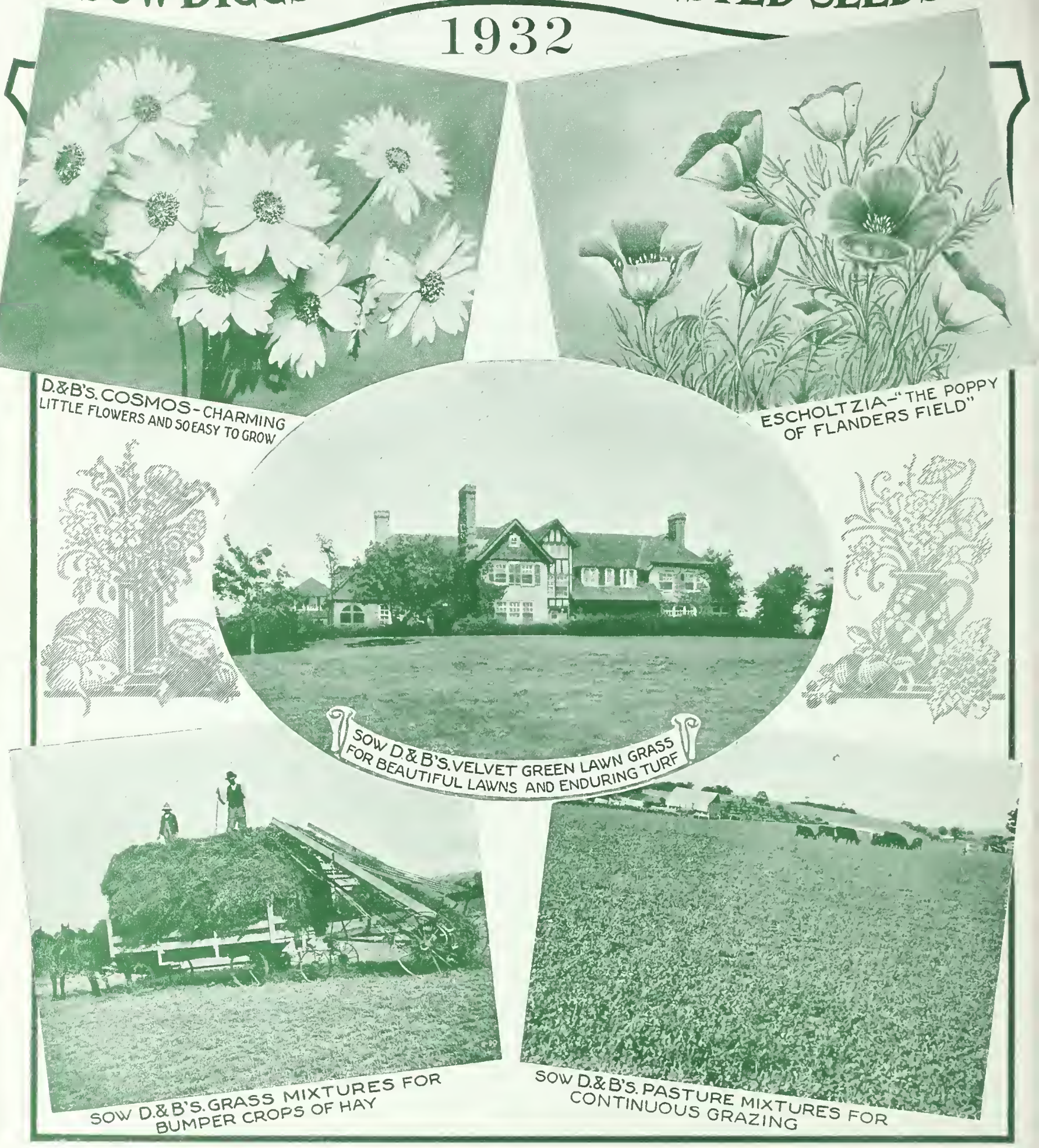

BEAUTIFY YOUR GROUNDS 光 ADD CHARM
TO YOUR HOME WITH COLORFUL FLOWERS
THEY COST SO LITTLE AND ADD SO MUCH 